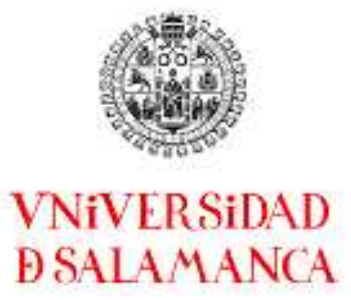

FACULTAD DE GEOGRAFÍA E HISTORIA

Departamento de Historia Medieval, Moderna y Contemporánea

Dimensiones histórico-sociológicas de la tortura en comisarías de Brasil: el caso de Pernambuco

TOMO I

MARCELO BARROS CORREIA

SALAMANCA, 2013 


\section{0 \\ 2464;05 \\ कर्तिए \\ VNiVERSiDAD \\ DSALAMANCA}

FACULTAD DE GEOGRAFÍA E HISTORIA

Departamento de Historia Medieval, Moderna y Contemporánea

Dimensiones histórico-sociológicas de la tortura en comisarías de Brasil: el caso de Pernambuco

TOMO I

TESIS DOCTORAL QUE PRESENTA MARCELO BARROS CORREIA, BAJO LA DIRECCIÓN DE LA PROFA. DRA. MARIA ESTHER MARTÍNEZ QUINTEIRO,

\&

DEL PROF. DR. JOSÉ LUIZ RATTON

EN EL MARCO DEL PROGRAMA DE DOCTORADO "PASADO Y PRESENTE DE LOS DERECHOS HUMANOS 

A mis hijos Matheus y Gabriel 


\section{AGRADECIMIENTOS}

A mi directora en España, Prof. Dra. María Esther Martínez Quintero, por su dedicación y orientación sin las cuales este trabajo no sería posible.

A la Universidad de Salamanca por haberme acogido y permitido disfrutar de sus excelentes instalaciones y condiciones de estudios excepcionales.

En Brasil mi agradecimiento al Gobierno del Estado de Pernambuco, junto con la Policía Civil, que concedieron mi licencia para hacer el doctorado en Salamanca.

A mi co-director, Prof. Dr. José Luiz Ratton, que contribuyó para que cambiara la idea que tenía de la policía y me empujó a ampliar mis horizontes de investigación. Además de que, con su arriesgado cambio de la teoría a la práctica, está consiguiendo cambiar la realidad de la seguridad pública en Pernambuco.

A los comisarios y agentes de policía que aceptaron ser entrevistados sobre un tema que resulta tan difícil, pues gracias a sus colaboraciones fue posible aportar algo muy valioso a mi Tesis. Por razón de seguridad no puedo mencionar sus nombres, pero ellos posibilitaron que aportara algo nuevo a esta discusión, sirviéndome de estímulo cuando tiempo después me dedicaba a las transcripciones de sus entrevistas.

A mis padres, José Vicente Correia (in memorian) y Josefa Barros Correia por toda la atención y esfuerzo que me dedicaron. A mis hermanos, Eduardo y Neide, por el apoyo y ayuda de siempre. 
Fala-se muito da remoção de "maçãs podres". Fala-se pouco de porque as maçãs apodrecem. É que no barril há lugares, há relacionamentos, que convidam ao apodrecimento.

(MUNIZ, 2007: 40). 
Dimensiones histórico-sociológicas de la tortura en comisarías de Brasil: el caso de Pernambuco 


\section{Dimensiones histórico-sociológicas de la tortura en comisarías de Brasil: el caso Pernambuco}

\section{ÍNDICE}

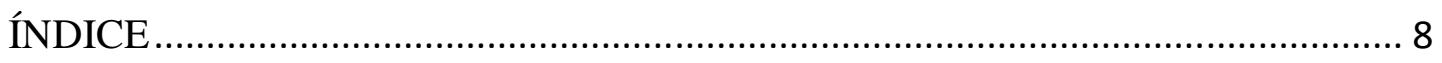

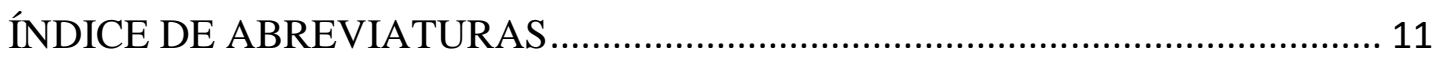

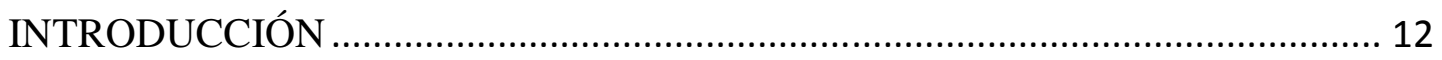

Objeto de estudio, objetivos e hipótesis de trabajo ...................................................... 12

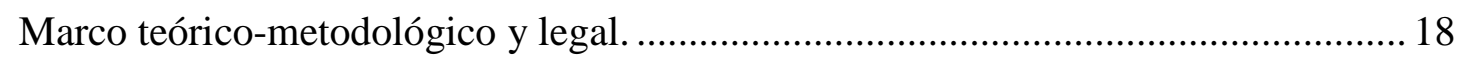

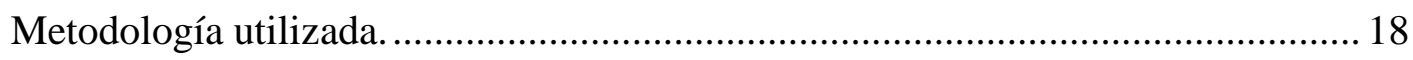

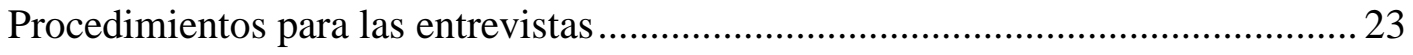

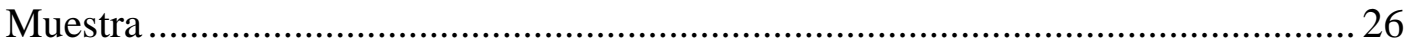

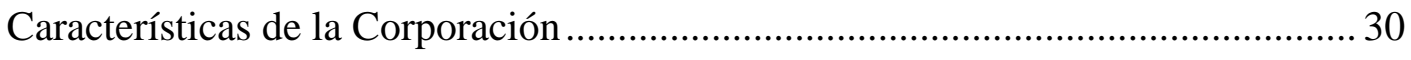

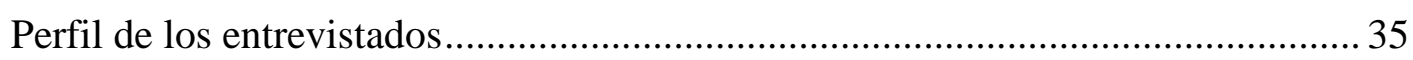

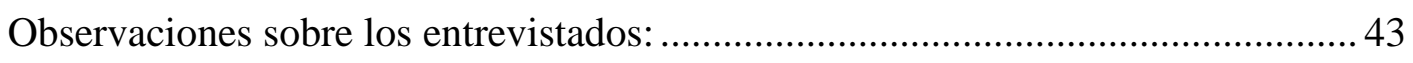

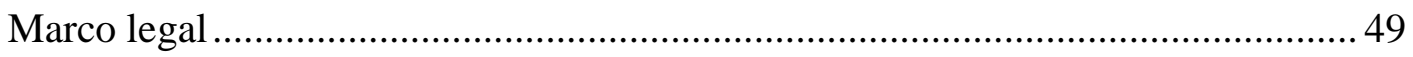

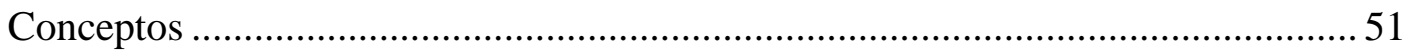

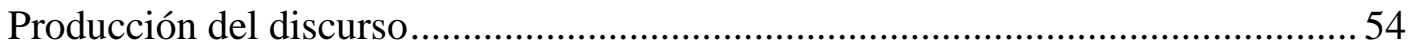

1. BREVES NOTAS HISTÓRICAS SOBRE LA TORTURA ……………………. 58

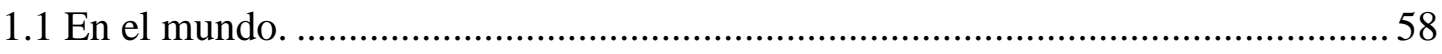

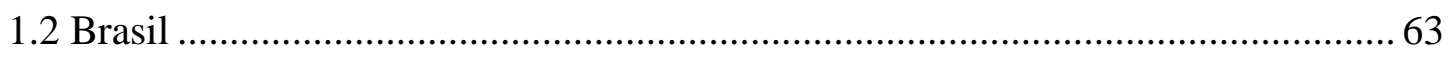

1.2.1 Creación de los modelos actuales de policía .................................................... 81

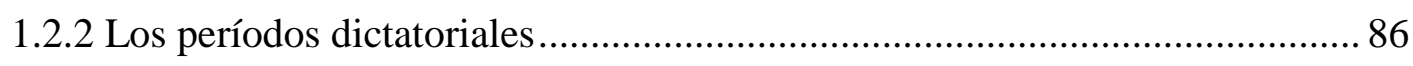

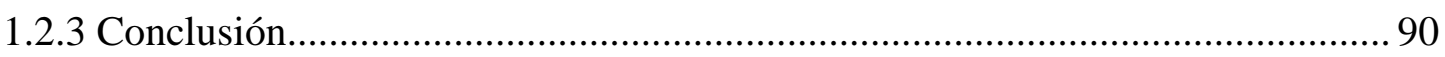

2. ASPECTOS ÉTICOS LEGALES DE LA TORTURA ………………………...... 93

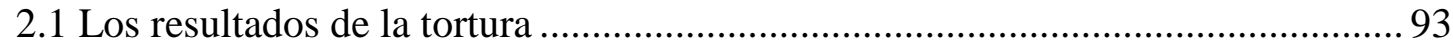

2.2 El debate sobre los justificantes "morales" esgrimidos para el uso de la tortura

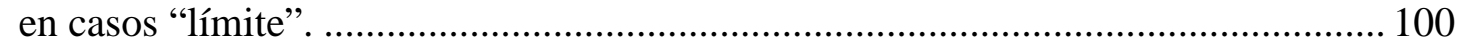

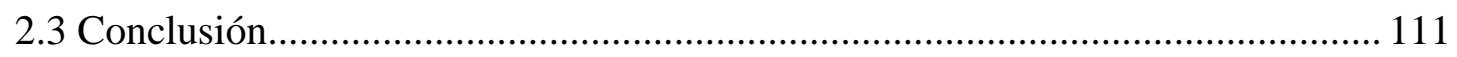




\section{Dimensiones histórico-sociológicas de la tortura en comisarías de Brasil: el caso Pernambuco}

3. CULTURA CORPORATIVA..... 112

3.1 La Cultura Corporativa en el contexto de la Teoría Económica del Delito..... 119

3.1.1 Incentivos a la tortura. 122

3.1.1.1 Asimilación de la tortura 122

3.1.1.2 Presunta eficiencia del método 144

3.1.1.3 Ascenso/ prestigio 154

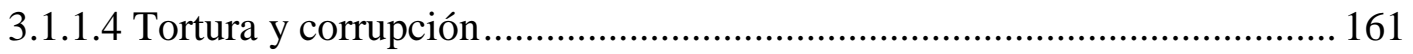

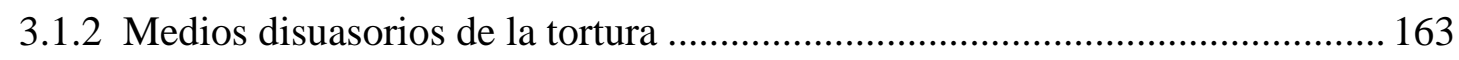

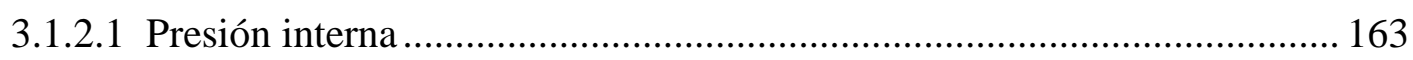

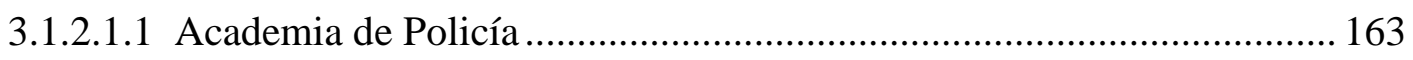

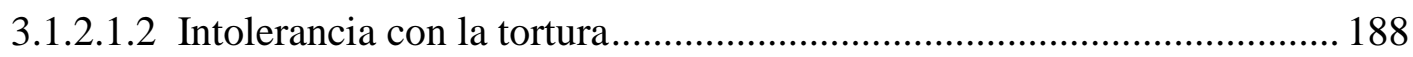

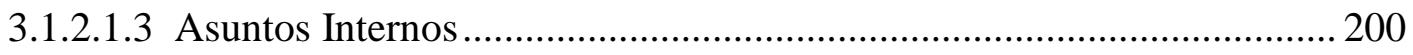

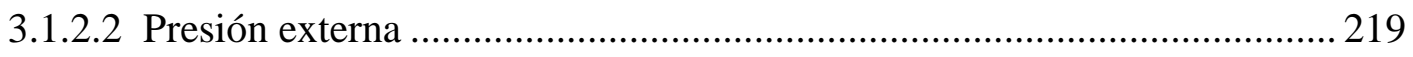

3.1.2.2.1 Influencia de la Constitución Federal de 1988 .................................... 219

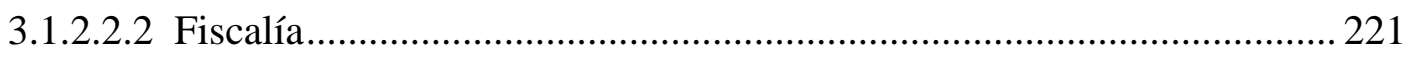

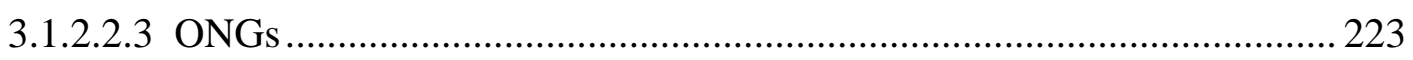

3.1.2.2.4 Intolerancia de la sociedad con la tortura ....................................... 225

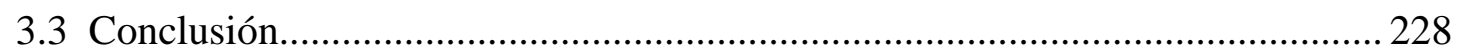

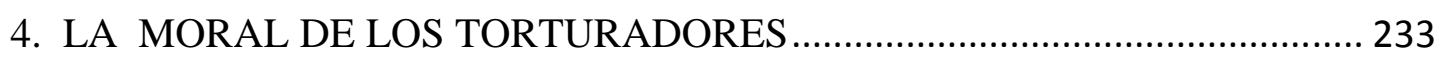

4.1 La "violencia burocrática", el "machismo", el deseo de integrarse y el "poder

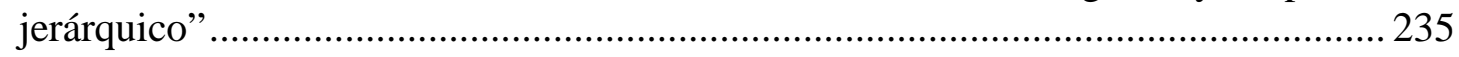

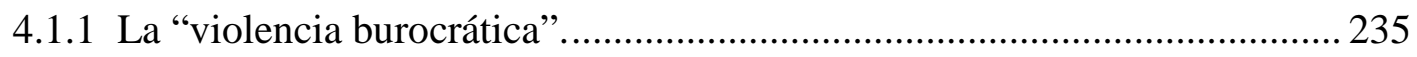

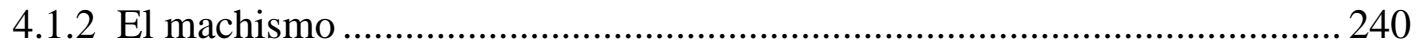

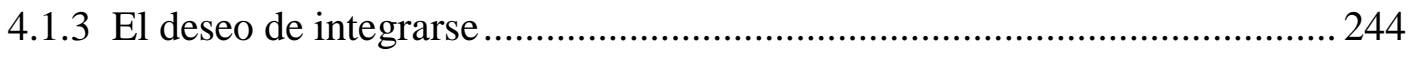

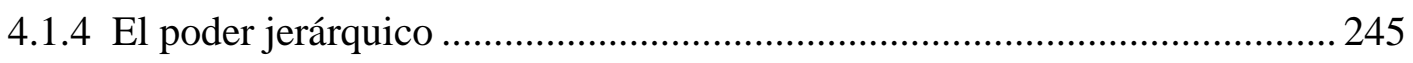

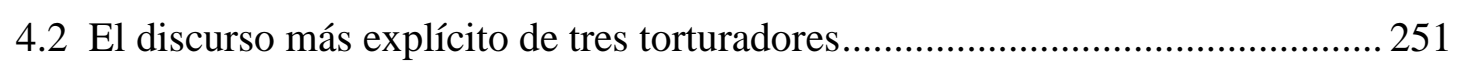

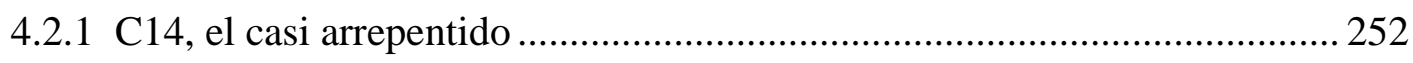

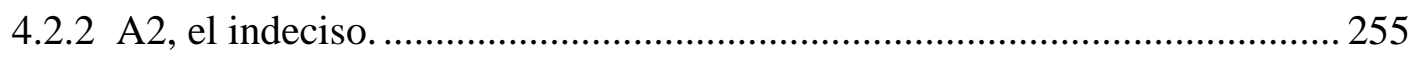

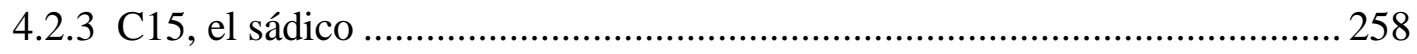

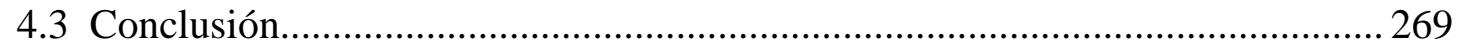


Dimensiones histórico-sociológicas de la tortura en comisarías de Brasil: el caso Pernambuco

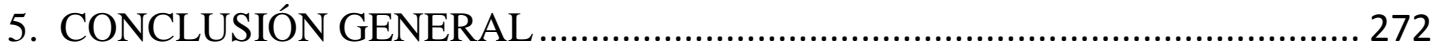

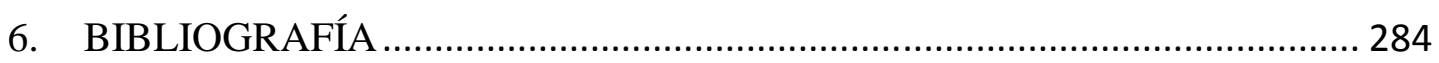

7. NOTAS DE TRADUCCIÓN DE LAS ENTREVISTAS ................................... 304 
Dimensiones histórico-sociológicas de la tortura en comisarías de Brasil:

el caso Pernambuco

\section{ÍNDICE DE ABREVIATURAS}

$\mathrm{AI}$ - Asuntos Internos (corregedoria)

CF - Constitución Federal de 1988

CT - Convención contra la Tortura y otras Penas Crueles y Degradantes

CI - Convención Interamericana de Combate a la Tortura

LT - Ley de Tortura $(9.455 / 97)$

MP - Ministerio Público (Fiscalía)

ONU - Organización de las Naciones Unidas

PAD - Procedimiento Administrativo Disciplinar

PC - Policía Civil

PM - Policía Militar

SDS - Secretaría de Defensa Social

SENASP - Secretaría Nacional de Seguridad Pública 


\section{Dimensiones histórico-sociológicas de la tortura en comisarías de Brasil: el caso Pernambuco}

\section{INTRODUCCIÓN}

\section{Objeto de estudio, objetivos e hipótesis de trabajo}

En países con una democracia consolidada y una tradición basada en el respeto a los derechos humanos, la policía ejerce, teóricamente al menos, una actividad directamente vinculada con los principios democráticos y de derechos humanos. Si esto es así en las democracias consolidadas, lo es más aún para los países que pasaron por una transición democrática en los últimos cincuenta años.

La policía representa la primera institución responsable de la aplicación de la ley, pero también es el brazo armado del Estado. Es por ello que no se debería descuidar su funcionamiento, organización y doctrina ${ }^{1}$. En lo que se refiere a la práctica de crímenes de tortura, la policía es la principal -aunque no la únicainstitución que comete este tipo de violación de los derechos humanos actualmente. Si antiguamente su práctica era permitida a todos los "ciudadanos", más tarde sólo le fue legitimada al Estado y hoy en día, es penalizada para todos y aún más para los miembros representantes del Estado. Sin embargo el Estado brasileño sigue tolerando su práctica sin mayores problemas.

En Brasil, es muy común encontrar hasta hoy teorías que simplifican la explicación de la permanencia del uso de la tortura como consecuencia del periodo de dictadura militar instalada en el país entre 1964 y 1984². Posición ésta difícil de

\footnotetext{
1 "Muito pouco sabemos sobre a polícia e seu trabalho, apesar de sua centralidade nos fluxos da vida cotidiana - cientistas, leigos e policiais preenchem lacunas cognitivas com crenças mitológicas -, e os resultados analíticos e normativos desse procedimento são desastrosos". (PAIXÃO, 1995: 18).

2 Véase COIMBRA (a): "Tortura no Brasil como herança cultural dos períodos autoritários".
} 


\section{Dimensiones histórico-sociológicas de la tortura en comisarías de Brasil: el caso Pernambuco}

sustentar, después de una breve revisión histórica en la que surgen evidencias que dan cuenta de la práctica de la tortura antes del período de la dictadura ${ }^{3}$, o de la práctica generalizada en las más diversas partes del mundo -con o sin dictaduras ${ }^{4}$ - y en las más diversas épocas.

La tortura está presente en toda la historia del Brasil y desde un inicio fue considerada como algo normal, legal y aceptable, cuando no explícitamente recomendable cuando era dirigida hacia determinados grupos sociales. El mayor problema es entender por qué, después de ser derogada del ámbito legal y siendo ya castigada de forma muy severa en el Código Penal, aún continuó siendo una práctica clandestina en los aparatos represores.

Veinte años después de la Constitución Federal (CF) de 1988, la cual es muy avanzada en relación a la garantía de los derechos humanos, y de una legislación específica: Lei de Tortura (LT) que entró en vigor en 1997 (Ley nº 9.455), además de diversos tratados relacionados con los derechos humanos, continuamos viendo que la tortura es empleada sin la mínima repercusión para el torturador, en todos los Estados de la federación brasileña (véase Adorno, Caldeira, Cano, Cardia, DaMatta, Da Silva, Holloway, Kant de Lima, Mingardi, O’Donnell, Pinheiro, Ratton, Rolim, Sapori, Soares, Zaluar e, muitos outros autores). En reciente visita a la Universidad de Harvard, la presidenta de Brasil, Dilma Rousseff, al ser preguntada sobre las violaciones de los derechos humanos, afirmó que "no sé como ocurre, no tengo capacidad de impedir que en las comisarías de Brasil no haya tortura " ${ }^{5}$. La noticia

3 ¿De ónde viene esa vinculación entre prácticas actuales de la tortura y el período dictatorial? La contestación puede venir de los perseguidos prioritarios del régimen dictatorial: periodistas, políticos y, principalmente, estudiantes y profesores universitarios.

$4 \quad$ Francia, durante la guerra de Argelia, y Estados Unidos, después del 11 de septiembre, son dos ejemplos de cómo países con fuerte tradición de defensa de los derechos humanos pueden verse involucrados en denuncias de uso de la tortura.

5 La presidenta, que ya fue torturada durante el régimen dictatorial de 64-84, afirmó en 10/04/12, en la Universidad de Harvard: "Do ponto de vista do Brasil, sempre que podemos e temos oportunidade manifestamos o interesse do país em defender os direitos humanos. Agora posso te dizer 


\section{Dimensiones histórico-sociológicas de la tortura en comisarías de Brasil: el caso Pernambuco}

publicada en internet chocó a algunas ONGs que trabajan por los derechos humanos, pero hubo total apoyo al discurso de la Presidenta en los comentarios de los internautas.

Considerando la tolerancia de la sociedad y de las organizaciones del sistema de Justicia ${ }^{6}$ frente al uso de la tortura como medio de investigación, ¿cómo podemos explicar que funcionarios encargados de cumplir la ley la violen de forma más cruenta que los crímenes que se proponen descubrir? ¿Cómo explican y justifican tal acción? ¿Qué ocurre para que ciudadanos comunes que no tenían un pasado de violencia empiecen a torturar en nombre del Estado y pongan sus trabajos y medios de supervivencia en riesgo ante prácticas que en principio no conllevan una ganancia directa para ellos? ¿Acaso tales prácticas comportan para quienes las efectuam una ventaja oculta? ¿Y para los supervisores inmediatos? ¿Y para el alto escalafón del Gobierno? En ese conjunto de relaciones es necesario comprender las razones de quien practica la tortura $y$, de igual manera, de quien la conoce y no hace nada para evitarla; la ignora, la disculpa, la apoya y hasta la recompensa.

Esta Tesis parte de la idea de que la tortura todavía es practicada en las comisarías de policía en Brasil ${ }^{7}$, y probablemente continuará siéndolo por un tempo con independencia de los tratados y compromisos de respeto a los derechos humanos

uma coisa, o Brasil tem grandes desrespeitos aos direitos humanos. Não sei como acontece, não tenho como impedir que nas delegacias do Brasil não haja tortura". (PERNAMBUCO.COM).

6 "A Amnistia Internacional constatou que a atividade policial violenta e repressiva corre o risco de se transformar na consequência aceitável - entre certos elementos integrantes dos órgãos oficiais, da imprensa e do público - da manutenção de um sistema de justiça criminal submetido a intensas pressões de natureza social, econômica e política". (ANISTIA INTERNACIONAL, 2001: $05)$.

7 "No início do século 21, a prática da tortura e de formas cruéis, desumanas e degradantes de tratamento no Brasil permanece difundida e sistemática. (...) Tais provas, na realidade, indicam o uso repetido e calculado de tortura ou maus-tratos em muitas das delegacias policiais e centros de detenção de todos os 26 estados do país, bem como no Distrito Federal, não como prática oficial, mas como método consagrado de policiamento ou controle nas instituições correcionais". ANISTIA INTERNACIONAL, 2001: 05). 


\section{Dimensiones histórico-sociológicas de la tortura en comisarías de Brasil: el caso Pernambuco}

que Brasil firme, pues no se han trabajado de manera adecuada ni las causas, ni los efectos de la práctica de la tortura.

Para mudar esa situación es necesario comprender por qué los agentes de la ley insisten, incluso corriendo riesgos legales y morales, en continuar empleando la tortura en su trabajo diario y qué políticas públicas pueden ser desarrolladas para evitarla.

Entre las razones de su utilización, está el hecho de que la tortura, a su modo y pese a la ofensa de los más básicos derechos fundamentales, constituye en la praxis policial una especie de "técnica de investigación" considerada por algunos como dotada de cierto grado de "eficiencia" en la resolución de los crímenes y como fuente de réditos profesionales que favorecen la perpetuación de tal práctica.

Por ello, el uso de la tortura en las instituciones de investigación seguirá dándose mientras no se desarrollen otras técnicas y modelos de trabajo que vengan a sustituirla, o mientras se mantengan prácticas internas que faciliten su aceptación en el trabajo policial e imposibiliten un mayor control social.

Estas técnicas sustitutivas deben contener no solamente la garantía éticojurídica de los procedimientos exigibles por la doctrina de los derechos humanos, sino también los niveles de eficiencia semejantes o incluso mayores que los que presuntamente proporciona la tortura.

Considerando la aceptación de la sociedad frente a tales prácticas, y sin apoyarnos exclusivamente en un determinismo histórico -que no es suficiente para explicar tal fenómeno-, intentaremos aportar nuevas informaciones a la discusión dirigiendo nuestra investigación a intentar comprender lo que lleva a los policías a practicarla, y por qué resulta tan difícil erradicarla.

A partir de tales consideraciones proseguimos en la investigación iniciada en nuestro Trabajo de Grado, que sólo estudiaba a los comisarios de la Policía Civil (policía judicial) y pasamos a incluir los agentes de la misma policía. Asimismo 


\section{Dimensiones histórico-sociológicas de la tortura en comisarías de Brasil: el caso Pernambuco}

añadimos un análisis de la cultura corporativa; una discusión respecto la moral de los torturadores. También ampliamos las entrevistas de comisarios e incluimos los discursos de los agentes de policía.

También hemos optado por algunas hipótesis preliminares que buscan explicar por qué sigue en Brasil la barbarie de la tortura, tema central de nuestra tesis doctoral.

Hipótesis generales:

Hay una combinación de creencias culturales y mecanismos institucionales que favorecen la práctica de la tortura.

Actúan a favor de la tortura:

1.

La valoración en la cultura policial de la utilización de la tortura, así como de su eficiencia (aceptación, respeto, reconocimiento, integración, etc.).

2. La valoración en la cultura brasileña de la "necesidad" de tal práctica (presión de la sociedad).

3. La creencia de que hay tipos de crímenes que sólo se solucionan con ese "método de investigación" ("imprescindible" para algunos crímenes).

4. La ineficiencia de la policía (medios y capacitación) y la alta incidencia de crímenes, sumada a la presión para hallar soluciones, que empujan a los policías a la tortura (insuficiencia de medios).

5. La existencia de policías que incluso sin practicarla, la ignoran, la disculpan, la apoyan y la recompensan (apoyo implícito).

6.

Los réditos para los policías que la practican o que permiten su práctica son superiores (ascenso, prestigio, etc. - incentivos institucionales) a las expectativas de pérdidas (expediente disciplinario, despido, proceso criminal, etc. - castigos). 


\section{Dimensiones histórico-sociológicas de la tortura en comisarías de Brasil: el caso Pernambuco}

La presente Tesis se divide en seis partes: introducción; breves notas históricas sobre la tortura; aspectos éticos legales de la tortura; cultura corporativa; la moral de los torturadores; y, conclusión.

En la introducción se presenta la metodología y los marcos legales y teóricos del estudio.

En el capítulo de las breves notas históricas sobre la tortura, en Brasil y en el mundo, buscamos contextualizar cómo fue poco a poco introducida y alejada en lo cotidiano y en el proceso penal a lo largo de la Historia.

El capítulo de los aspectos éticos legales de la tortura recoge las discusiones sobre la utilización de la tortura, consideraciones sobre la eficacia o no de la tortura y algunas razones esgrimidas por los torturadores para usarla, o no. Establece una discusión sobre el supuesto de la "legitimidad" de la tortura en la actividad policial, relacionando aspectos éticos y prácticos.

El capítulo de la cultura corporativa, nuestro marco teórico, presenta los fundamentos de la cultura corporativa, incentivos y castigos a quien practica la tortura, además de los discursos de los comisarios y agentes de policía entrevistados que serán resumidos en el capítulo siguiente, donde recogemos las conclusiones.

El capítulo de la moral de los torturadores sirve para analizar los valores e ideas de los policías que confesaron ser torturadores.

De esa forma este trabajo pretende realizar un estudio teórico sobre la historia de la tortura en Brasil y sobre los aspectos éticos y prácticos de su aplicabilidad en la actividad policial, contextualizando con los discursos de comisarios y agentes de la Polícia Civil de Pernambuco ${ }^{8}$, buscando comprender en qué medida sus prácticas internas pueden contribuir al mantenimiento de la tortura.

8 Ver: SILVA, 2006. Aunque tratando del mismo tema "tortura" y trabajando con la misma "policía de Pernambuco", como hizo SILVA (Celma F. Tavares de Almeida - Barbarie en la democracia), este trabajo busca plantear nuevos aspectos para la discusión centrando la mirada no en 


\section{Dimensiones histórico-sociológicas de la tortura en comisarías de Brasil: el caso Pernambuco}

\section{Marco teórico-metodológico y legal.}

\section{Metodología utilizada.}

Utilizamos fundamentalmente cuatro procedimientos: el primero fue realizar, antes de empezar el trabajo de campo, un conjunto de lecturas tratando de la tortura en las áreas de la Historia, la Ciencia Política, la Sociología y la Filosofía, a las que añadimos otras lecturas en el curso de la investigación, tales como las efectuadas sobre cultura corporativa, pedagogía profesional, análisis de discursos y psicología. En el segundo lugar buscamos documentos sobre el castigo penal a policías que practican la tortura. En tercer lugar entrevistamos a comisarios y agentes de la policial judicial (policía de investigación).

Para el capítulo de la historia de la tortura contamos principalmente con artículos y libros de Edward Peters y Valdir Sznick, para la historia de la tortura en el mundo; para la tortura en Brasil, los autores más utilizados fueron Boris Fausto, Caio Prado Júnior, Eduardo Bueno, Francisco C. T. da Silva, José Murilo de Carvalho, Laurentino Gomes, Thomas Holloway. Para la discusión sobre aspectos éticos morales de la tortura Alan Dershowitz, Michael Walzer y Michel Terestchenko fueron imprescindibles. Alba Zaluar y Celma Tavares son lecturas obligatorias para comprender la preferencia por las mismas víctimas, así como, Martha Huggins, Skolnick y Diego Torrente Robles para la cultura corporativa de los policías.

Las entrevistas, estructuradas, con comisarios de policía iniciadas en el Trabajo de Grado sirvieron para replantearnos los cuestionarios y dirigir las nuevas entrevistas con más comisarios y con los agentes de policía, buscando mejorar la

la víctima o en la sociedad, sino sobre los ejecutores de tales atrocidades. Además la base teórica es bien distinta de modo que se puedan añadir otras teorías a la discusión. 


\section{Dimensiones histórico-sociológicas de la tortura en comisarías de Brasil: el caso Pernambuco}

comprensión de por qué torturan, por qué lo toleran y lo más importante, por qué persiste el uso de la tortura hasta hoy.

La elección de los comisarios como objeto de estudio se debe al hecho de que son los responsables finales de las investigaciones, así como del control y dirección de los agentes de policía. Es decir, activa o pasivamente son los principales responsables del uso, o no, de la tortura en las comisarías. Además, en el modelo brasileño hay una concentración de funciones en el comisario de modo que los agentes tienen poca autonomía. Los inquéritos ${ }^{9}$, esto es, las entrevistas e interrogatorios efectuados en una comisaría, así como las reclamaciones sobre eventuales abusos policiales, son competencia de los comisarios.

La inclusión de los agentes de policía en las entrevistas de la Tesis, aunque necesiten de la autorización o consentimiento de los comisarios, deriva de que ellos son los que ejecutan directamente la tortura y consecuentemente corren más riesgos. Por eso resulta muy importante darles voz.

Las informaciones fueron extraídas a través de entrevista con comisarios y agentes de policía que ejercieron en el pasado sus funciones en distintas comisarías, buscando, por medio de entrevistas semiestructuradas en profundidad, comprender las razones de la insistencia en tal práctica.

La Constitución Federal (CF) es importante por representar un marco histórico para la redemocratización brasileña y por la introducción, por primera vez en una constitución republicana brasileña, de fuertes intenciones contrarias a la

$9 \quad$ Inquérito es la formalización, documentación, de los actos de investigación, realizados por la policía judicial (Polícia Civil), de forma cronológica, con el objetivo de identificar la comisión de un delito, su autor y los medios de los qué se valió. El inquérito, cuando está concluído es enviado para la fiscalía, que después de análisis formaliza la denuncia en la justicia ou retorna para la policía para más investigaciones. Algo similar al atestado policial español. Según el Código de Proceso Penal de Brasil el responsable de tales investigaciones es el comisario, que tiene que firmarlo y estar presente en los interrogatorios y entrevistas. 


\section{Dimensiones histórico-sociológicas de la tortura en comisarías de Brasil: el caso Pernambuco}

práctica de la tortura; así como por el aumento considerable de poderes de la fiscalía sobre la policía, hasta la actualidad.

La "Ley de Tortura" entró en vigor hace doce años, y trató por primera vez específicamente sobre dicha cuestión con bastante rigor y severidad. Pero hoy día tiene una aplicación muy débil.

La presente investigación aporta nuevos elementos para la comprensión del fenómeno de la violencia estatal en Brasil: entrevistas con policías que hasta hoy practican o mantienen silencio ante la tortura. El éxito en la obtención de tales resultados dependió básicamente de dos factores que intentaremos aclarar a continuación:

El primero, fue la inusual elección de los perpetradores de la tortura como objeto de estudio, pues en general los académicos que tratan este asunto en América Latina tienen preferencia por el estudio de los torturados o víctimas ${ }^{10}$. Aparte de la dificultad para obtener testimonios creíbles de los torturadores algunos consideran que si el investigador intenta comprender las motivaciones del autor del delito, conocer las "razones" que le llevan a cometer tales actos, pudiera estar "contaminado" por su violencia, o incluso justificarla. Parece haber una lógica que partiendo de que tales prácticas son tan horrendas que no existe justificación posible, por esa razón, no hay que escuchar a tales personas. Hacerlo, podría parecer apriorísticamente una violencia contra las víctimas y podría dar la impresión de que el investigador acepta los argumentos de los verdugos.

Esa relación polarizada entre "víctima" y "perpetrador" de la tortura, donde el primero tiene la legitimidad y presunción de veracidad - en lo que concierne al delito por él sufrido-, y, el segundo es moralmente inferior en la "jerarquía de credibilidad", puede dificultar una mayor profundización de temas como la violencia, al presentar

10 Pasa lo mismo con el tema de la violencia contra la mujer, racismo, y contra otros grupos vulnerables. 


\section{Dimensiones histórico-sociológicas de la tortura en comisarías de Brasil: el caso Pernambuco}

solamente la versión de un sujeto (el pasivo) de la relación estudiada. Pese a eso, dada la ausencia de estudios sobre los discursos de los torturadores, los elegimos como objeto de nuestra investigación, conscientes de que investigarlos no significa legitimarlos.

El segundo elemento que facilitó nuestra investigación es que el investigador está involucrado con el objeto investigado, pues soy miembro de la organización investigada. Para Valles (2007: 78) eso establece una jerarquía entre investigador e investigado que puede ser de superioridad, inferioridad o igualdad, circunstancias que "pueden acarrear ciertos comportamientos de distanciamiento, temor o camaradería hacia el entrevistado, que pueden distorsionar la entrevista”.

Sin embargo, en nuestro caso la condición de comisario de policía (entrevistador), permite crear una situación de igualdad y confianza que posibilita la obtención de informaciones de otros comisarios (entrevistados), advertidos de que se trata de una entrevista para una tesis doctoral, y que se omitirán los datos que permitan su identificación, asegurándoles el secreto profesional. Tal condición permite conocer el problema en profundidad, lo que implica cuestionarios más eficientes; identificar a los entrevistados que tienen más informaciones; obtener informaciones que no sería reveladas sin la relación de confianza ${ }^{11}$.

No podemos olvidarnos de que la organización policial es una de las más cerradas, y que las conductas aquí descritas representan delitos. Por lo tanto, son informaciones mucho menos accesibles para las persona ajenas a esta institución.

\footnotetext{
11 Como especialista em polícia, Huggins observou que, “em vários cenários culturais, se os que entrevistam policiais são reconhecidos como 'do ramo', sendo naturalmente os próprios policiais os mais legítimos entre os que são dessa classificação, o entrevistador será mais prontamente aceito pelos possíveis policiais entrevistados.” (HUGGINS, 2006: 88).
} 


\section{Dimensiones histórico-sociológicas de la tortura en comisarías de Brasil: el caso Pernambuco}

Otro punto que merece ser destacado es que nos vemos abocados a escuchar relatos de delitos sin tomar las medidas pertinentes ${ }^{12}$. Estamos hablando de crímenes que en algunos casos aún están ocurriendo.

Estamos recogiendo testimonios de un tipo de delito que los policías saben que ocurre, los fiscales y jueces saben que ocurre, los académicos y la sociedad también lo saben. Incluso fuera de Brasil, se sabe que ocurre ${ }^{13}$. Pero hasta el momento, es muy difícil de probar, pues los policías se niegan sistemáticamente a admitirlo. Y es que parece existir una "ley del silencio" que nadie quiere violar.

En este sentido creemos que nuestra posición de "observador privilegiado", aun difícil, permite sacar a la luz hechos hasta ahora ocultos, o tal vez, ni siquiera buscados. Eso puede ser útil para presionar a los Gobiernos para que actúen y también para ayudar a la elaboración de políticas públicas más efectivas.

\footnotetext{
12 En la posición de comisario de policía estoy obligado, por ley, a elaborar un atestado (inquérito) policial cuando tengo conocimiento de cualquier práctica criminal.

13 Amnistía Internacional llegó a afirmar que la policía brasileña era la más violenta del hemisferio occidental.
} 


\section{Dimensiones histórico-sociológicas de la tortura en comisarías de Brasil: el caso Pernambuco}

\section{Procedimientos para las entrevistas}

Sabíamos que obtener la confesión de policías que aún están practicando la tortura sería algo muy difícil, y por eso pretendíamos conseguir informaciones indirectas, aunque fuera difícil por tratarse de un tema "tabú".

Por eso contábamos con la complicidad que podría existir, por ser integrante del mismo cuerpo de policía (pues cuando algún entrevistador, extraño a la policía, se presentaba para una entrevista y preguntaba si existía la tortura siempre escuchaba que eso era un problema que no existía, o era muy raro) ${ }^{14}$. Así que al presentarnos a los entrevistados decíamos que estábamos haciendo una tesis doctoral y que necesitábamos entrevistar a policías que quisieran hablar sobre el uso de la tortura física como método de investigación. También garantizábamos que el sigilo sería total.

Para nuestra sorpresa, la mayoría habló en primera persona y declaró mucho más de lo que esperábamos oír. En la primera fase, buscamos a once comisarios de policía, todos con más de diez años en el cargo y con experiencia en varios tipos de comisarías (ubicadas en la Capital, interior del Estado y comisarías especializadas), provenientes de distintas oposiciones y trabajando en comisarías diversas.

\footnotetext{
14 "Se encuentran, por un lado, los miembros de las organizaciones profesionales ligadas a las fuerzas de seguridad formando un grupo más o menos homogéneo en el sentido de minimizar la práctica de la tortura ('es cosa del pasado', 'era absurda, ahora ha mejorado', 'no tengo conocimiento de que alguien la use como instrumento de trabajo') o de disfrazarla con nombres más aceptables, como 'abusos' y 'excesos'. También de calificarla como 'acto aislado'. Por otro lado, se encuentran la mayoría de los entrevistados de las demás organizaciones profesionales e instituciones, como las responsables del peritaje, el Ministerio Público, las relacionadas al sistema penitenciario e incluso el Poder Judicial, admitiendo su existencia y subrayando el grado con el que se practica: 'es constante y frecuente', 'es una práctica habitual', 'existe en una escala acentuada'”. (SILVA, 2006: 248-249).
} 


\section{Dimensiones histórico-sociológicas de la tortura en comisarías de Brasil: el caso Pernambuco}

De los once comisarios que seleccionamos para entrevistar, en el primer bloque de 2010, siete aceptaron hablar y aportaron informaciones muy importantes, e incluso señalaron cuestiones de las que no nos habíamos dado cuenta y que servirían como futuras hipótesis. Sin embargo, de los siete que se aprestaron a colaborar, tuvimos que excluir a uno, pues supimos -a través de conversaciones anteriores, en las que había hablado sobre la tortura- que no decía la verdad. En un segundo momento (2011) cinco comisarios fueron invitados y cuatro aceptaron hablar.

En cuanto a los comisarios que no aceptaron respondernos, en el primer bloque (2010), dos, muy cercanos a nosotros, se disculparon y rápidamente cambiaron de tema. Ante nuestra insistencia sobre la confidencialidad y sobre la necesidad de obtener tales entrevistas se negaron a hablar más sobre la cuestión. El otro, que era un comisario que no tenía ninguna proximidad, y que sabíamos que practicaba la tortura, fue muy duro en su posición y adoptó una postura de rechazo parcialmente violenta, sin aceptar hablar sobre el asunto. En el segundo bloque, la única mujer del grupo no aceptó ser entrevistada. Fue muy educada, pero rechazó la invitación. Al ser una comisaria que aún estaba en el "estágio probatório", especie de prácticas en los tres años iniciales, imaginamos que esa fue la razón de su negativa. Al no conocerla ni tener confianza con ella, no hubo espacio para insistir.

En 2011 también buscamos entrevistar a ocho agentes de policía. No conocíamos a ninguno de ellos, excepto en un trabajo de guardia, momento en que aprovechamos para hablar de la encuesta y del trabajo de la tesis. La mitad no aceptó la entrevista. Los que hablaron, casi todos, excepto uno, hablaron muy tranquilos y aportaron muchas informaciones. Pero en ese segundo momento percibimos que las entrevistas empezaban a saturarse, pues las contestaciones eran muy repetitivas, sin importar quién fuera el entrevistado. La principal diferencia que encontramos entre los discursos de agentes y comisarios fue en la proporción de torturadores, pues todos los agentes de policía habían torturado mientras que "sólo" mitad de los 


\section{Dimensiones histórico-sociológicas de la tortura en comisarías de Brasil: el caso Pernambuco}

comisarios lo habían hecho. Si la pregunta era cuántos habían presenciado estos actos, se trataba de un $100 \%$ de los agentes y un $80 \%$ de los comisarios. Y, si la pregunta era cuántos conocían comisarios, agentes y escribientes torturadores la respuesta era de $100 \%$ para agentes y comisarios ${ }^{15}$.

El hecho de comenzar por las entrevistas de comisarios y agentes conocidos, o a través de otros conocidos, permitió disminuir la reserva tan característica de los policías. Pero también entrevistamos policías desconocidos y, para nuestra sorpresa fueron muy colaboradores. Algunas veces, los extraños fueron mucho más colaboradores que los conocidos. Tres entrevistados solicitaron contestar la entrevista por mail y lo permitimos sin más dificultades. En verdad eso facilitó, pues no teníamos que hacer la transcripción, pero en algunos casos disminuía un poco la extensión de las entrevistas, pues ellos eran más sucintos que los entrevistados con grabadora. Además, aseguramos que la identidad de los entrevistados no sería revelada. Los detalles sobre cada entrevistado figuran más abajo, en el perfil de los entrevistados.

Confrontamos la tesis con un comisario, también académico, y, para nuestra sorpresa él identificó algunos entrevistados, incluso con los nombres falsos. Eso nos obligó a cambiar otra vez los nombres y a disminuir las informaciones respecto el perfil de los entrevistados.

15 Recordamos que se trata de una investigación cualitativa y que esos porcentajes se refieren solamente al bloque de los entrevistados, sin valor como estadísticas. 


\section{Dimensiones histórico-sociológicas de la tortura en comisarías de Brasil: el caso Pernambuco}

\section{Muestra}

La elección de qué comisarios y agentes de policía serían entrevistados fue inicialmente definida por nuestra propia experiencia y conocimiento de quiénes eran los comisarios más indicados para hablar sobre este asunto. O bien por posibles prácticas de tortura o por conocimientos de las mismas. Después de las entrevistas iniciales usamos el método de "bola de nieve" 16 para descubrir otros nombres.

También buscábamos comisarios y agentes de policía que conocíamos - por tanto, confiaban en nosotros-, o cuando teníamos alguna indicación de otro comisario o agente de policía que el entrevistado conocía, como una forma de establecer una relación de confianza.

Algunos comisarios que sabíamos que eran torturadores o que tenían buena información sobre el asunto se negaran a cooperar, pero acabaran indicando otro nombre para realizar las entrevistas ${ }^{17}$.

Hubo un caso, el de "C9", él mismo torturador y de cuya tolerancia con la tortura practicada por otros policías de su equipo sabíamos, pero al iniciar la entrevista lo negó todo, y no fue posible aprovechar esta fuente de la que esperábamos mucho.

Después de las primeras entrevistas decidimos no usar expresiones o preguntas muy directas al inicio para evitar que entorpecieran la comunicación. Después de las dos primeras percibimos que cuando preguntábamos sobre la Academia o sobre el período de la Dictadura, los entrevistados tenían muy poco que

\footnotetext{
16 Se solicita que cada entrevistado indique el nombre de otra persona que pueda contribuir al trabajo. En caso de entrevistados desconocidos se pide la presentación de quién lo hubiera indicado inicialmente como una medida para fomentar la confianza.

$17 \quad$ Ese es un procedimiento ya bastante conocido entre entrevistadores, donde alguien que no se quieren comprometer con una entrevista, transfieren el problema a otra persona.
} 


\section{Dimensiones histórico-sociológicas de la tortura en comisarías de Brasil: el caso Pernambuco}

decir. Así que hicimos esas preguntas de forma más libre al empezar las entrevistas para relajarlos antes de formular las preguntas más significativas.

Hubo casos en los que era evidente la incomodidad de algunos en pronunciar la palabra tortura y usaban expresiones como "violencia", "contundentes", "tirar serviço" ("sacar trabajo adelante"), etc. Entonces tuvimos que elegir cautelosamente las palabras que usaríamos para referirnos a la tortura, principalmente al inicio de la entrevista.

Para tener una muestra más ecuánime, en una primera fase buscamos once comisarios con más de diez años de práctica, que habían pasado por varias comisarías de la Capital, interior del Estado y comisarías especializadas, así como de oposiciones distintas. De los once entrevistados, tres eran mujeres. De los ocho hombres, dos se negaron y el tercero aceptó, pero dio una falsa entrevista. De las tres mujeres solamente una se negó a hablar.

En una segunda fase entrevistamos a cuatro comisarios y una comisaria. La comisaria se negó. Dos comisarios aceptaron, pero solicitaron hacer la entrevista por mail. También tratamos de entrevistar a ocho agentes de policía, 6 hombres y dos mujeres. Cuatro hombres aceptaron, los demás no. Tres agentes más antiguos, que no aceptaron, parecieron molestarse con el tema de mi tesis y dijeron que en otro momento podrían colaborar. De los que hablaron, todos fueron muy cordiales y parecieron muy sinceros, excepto un agente, A3, que parecía temer algo y que dividió su entrevista en dos momentos: el pasado y el presente. Del pasado él contaba todo; Del presente, negaba todo, o "no conocía" nada.

En los dos bloques de entrevistas nos sorprendimos con la naturalidad y cantidad de información que los entrevistados nos transmitían. Mucho más de lo que esperábamos escuchar. 


\section{Dimensiones histórico-sociológicas de la tortura en comisarías de Brasil: el caso Pernambuco}

Todas las entrevistas fueron realizadas por nosotros, así como las respectivas transcripciones, buscando de esa forma perder la menor cantidad de informaciones posibles. Para posibilitar las entrevistas garantizamos el anonimato de los entrevistados anunciándoles que se les citaría con nombres falsos.

Las preguntas usadas en las entrevistas tenían la siguiente estructura: formación policial; existencia de la tortura en las fuerzas policiales; tolerancia, interna y externa, con la tortura; ventajas directas e indirectas con el uso de la tortura; punición; presión por resultados; actuación de ONGs y de la Fiscalía; presión de los medios de comunicación; relación entre tortura y corrupción. También se buscaba impresiones más personales sobre las razones para la práctica de la tortura (véase cuestionario - anexo III). Todas las entrevistas fueron grabadas (excepto cuatro realizadas por e-mail) y después transcritas.

Cuando iniciamos nuestro trabajo, una de las cuestiones que más nos sorprendía era el modo en que las personas que no habían tenido ningún pasado de violencia o incluso eran contrarios a cualquier forma de violencia, habían pasado a practicar la tortura en cuando participaron en determinados grupos o cargos en la policía.

¿Qué podríamos decir de los policías que torturan? ¿Son personas violentas que procuran los trabajos y sectores más violentos? ¿O son por eso elegidos por la organización policial? ¿En qué medida los policías que practican la violencia extrema son esencialmente diferentes de los que no tienen ese hábito? ¿Y los que presencian ese suceso y (...) callan? ¿Y los que saben que ocurre y no hacen nada para evitarlo? ¿Quiénes son esos “monstruos"18?

\footnotetext{
18 "Concentrar a atenção apenas sobre os 'astros' perpetradores mais visíveis, que, na verdade, o mais das vezes são politicamente muito menos poderosos que o elenco de apoio dos facilitadores da violência, contribui para garantir o sigilo, o anonimato e a proteção - e o poder permanente - tanto dos que ordenam quanto dos que apóiam a violência estatal." (HUGGINS et al, 2006: 70).
} 


\section{Dimensiones histórico-sociológicas de la tortura en comisarías de Brasil: el caso Pernambuco}

Como apunta Huggins, los policías brasileños de unidades especiales, en el período de la dictadura del 68, que perpetraron algunas de las barbaridades más impactantes en nombre del Estado no eran, de entrada, esencialmente diferentes de otros policías, desde el punto de vista social e psicológico, que podrían haber estado en condiciones de hacer lo mismo y no lo hicieron. Así pues, si se puede demostrar que la peor violencia policial fue determinada por ciertos tipos de procesos sociopsicológicos y organizativos más amplios, por lo que es posible que la violencia policial menos dramática (menos visible públicamente, aunque más difundida) esté igualmente determinada por aquellos tipos de procesos.

Cuando Huggins entrevistó a algunos torturadores del periodo de la dictadura percibió que entre ellos había personas sin ningún pasado o rasgo de violencia. Eran personas que se conmovían y se desesperaban cuando tenían el primer contacto con la tortura, pero que a continuación se convirtieron en destacados torturadores. A partir de tal información, optamos por subrayar dos condicionantes: la influencia de la Academia de Policía y su papel en la formación del policía y la influencia de la cultura corporativa ${ }^{19}$.

\footnotetext{
19 "A cultura policial se marca, finalmente, por um conservadorismo intelectual que, sob a capa do pragmatismo, privilegia o olhar rasteiro, a tomada en consideração apenas dos elementos concretos e o anti-intelectualismo. Tudo que se apresenta sob a forma de inovação, de experimentação ou de pesquisa suscita reações de rejeição imediata. Pelo fato de ser redutora de incerteza, a reprodução do 'eterno passado' congela os universos policiais en práticas rotineiras e bloqueia sua capacidade de se adaptar à mudança social. As políticas de modernização conduzidas nas polícias nos últimos anos tiveram de contar con essa realidade”. (MONET, 2001: 155).
} 


\section{Dimensiones histórico-sociológicas de la tortura en comisarías de Brasil: el caso Pernambuco}

\section{Características de la Corporación}

La policía de Pernambuco fue creada en 1841, inicialmente llamada “Chefatura de Polícia” (jefatura de policía), bajo la dirección de un jefe nombrado por el Presidente de Provincia, elegido entre los "desembargadores" del Tribunal. En 1898, en la República, había un jefe de policía, dos “delegados” (comisarios) en la Capital y un comisario en cada ciudad del interior del Estado, nombrados por el Secretario de Justicia. También había "subdelegados" y inspectores de barrios.

En 3 de junio de 1931 fue creado el actual modelo de seguridad pública con dos cuerpos de policías ${ }^{20}$ : la "Polícia Militar", con la misión de hacer el patrullaje de prevención, con trajes militares, indirectamente vinculada al ejército, trabajando en las calles para mantener el orden y seguridad; la "Polícia Civil", con la misión de jugar el papel de policía represiva, eso es, actuar después que hubo un delito. Ambas pasaron a tener estatus de ministério de Estado, siendo, en el caso de la "Polícia Civil", llamada "Secretaria de Segurança Pública”. En ese momento empieza a tener actividades más específicas de policía judicial y se aleja cada vez más de las actividades administrativas más típicas de ayuntamiento.

\footnotetext{
20 Se trata del modelo creado por Francia y adoptado en casi toda Europa donde hay una policía militarizada y una civil. La principal diferencia es que en Europa las dos policías hacen el ciclo completo de policía. Es decir, cada policía tiene capacidad y legitimidad para proceder desde la actuación de alguien hasta enviar los atestados a los juicios. En Brasil, a diferencia de los sistemas de policías del Occidente, la policía que encuentra a alguien practicando un delito y la detiene, no es la misma que envía los papeles al juez. Pues en la concepción brasileña una sólo previene y la otra sólo reprime. En Brasil hay en cada Estado (son 27, más la Capital del país) dos cuerpos de policía: uno civil y otro militar. Además, hay una policía federal, para los crímenes federales ocurridos en unidades federales; una policía para carreteras federales, para los crímenes ocurridos en carreteras federales; una policía de ferrocarriles federales, para crímenes ocurridos en ferrocarriles. También hay guardias municipales, para cuidar del patrimonio público y del tráfico, en las ciudades más grandes.
} 


\section{Dimensiones histórico-sociológicas de la tortura en comisarías de Brasil: el caso Pernambuco}

Siguiendo esa tendencia de profesionalización de la policía, en 1974 se crea la policía de carrera y se pasa a exigir que los comisarios posean una licenciatura en Derecho. En 1988 la Constitución Federal determina que el ingreso en los cargos públicos se dará exclusivamente a través de oposiciones públicas. Ya en 1999 la "Polícia Civil" pierde el estatus de secretaría de Estado cuando se dio la fusión de las secretarías de la "Policía Civil" y "Militar" en una nueva secretaría: "Secretaria de Defesa Social", bajo la dirección de alguien, policía o no, nombrado por el gobernador. El objetivo de esa medida era buscar uniformizar y sistematizar las acciones de seguridad, pero también ejercer más control en las fuerzas policiales.

Actualmente, la PC de Pernambuco cuenta con 516 comisarios, 696 escribientes y 4.249 agentes de policía. Para concurrir a una oposición de comisario es obligatoria la licenciatura en Derecho. Los agentes de policía también necesitan una licenciatura, pero de cualquier carrera, además de la oposición.

Cuando ingresan en la policía tienen que pasar por el curso de la academia de policía (véase capítulo Cultura Corporativa - Academia). El currículum de la academia de policía de Pernambuco, sigue una "Matriz Curricular" elaborada por la "Secretaria Nacional de Segurança Pública", con obligación de trabajar, transversalmente, con los temas de derechos humanos, racismo, desigualdad y grupos con menor protección social.

La principal función de la PC es actuar como policía judicial. Eso es, hacer las investigaciones pre-procesales, enviar a la fiscalía las informaciones de que hubo un delito, quien lo cometió, y cómo. Eso todo se formaliza en un instrumento llamado "inquérito policial". Otro aspecto significativo es el modelo de organización adoptado por la PC. Según Robles (1997) "la literatura internacional 


\section{Dimensiones histórico-sociológicas de la tortura en comisarías de Brasil: el caso Pernambuco}

especializada distingue cuatro tipos de organizaciones policiales: tradicional $^{21}$, racional-burocrático $^{22}$, profesional $^{23}$ y comunitario $^{24}$. En los últimos tiempos se habla de un quinto modelo híbrido que incorpora rasgos de todos ellos". El modelo organizativo más característico de Brasil, el tradicional ${ }^{25}$, está sufriendo un cambio desde hace más de veinte años.

A partir del fin de la Dictadura (1964-1984) y del inicio de la Constitución Federal de 1988 las policías de Brasil empezaron a virar hacia un modelo "profesional", con rasgos del modelo "racional-burocrático". El ingreso en la policía se producía exclusivamente por oposición, sin interferencia política, los comisarios tenían que ser licenciados en Derecho, había una necesidad de mostrar una policía moderna, distinta de la policía violenta y torturadora del pasado bien reciente. Creaban unidades especializadas y organigramas para toda la organización. Pero, aún había mucha interferencia política en los trabajos policiales y los policías siempre tenían excesiva libertad de acción, casi sin controles.

A partir de la Constitución Federal de 1988 las oposiciones pasaron a ser una exigencia obligatoria para el ingreso en la policía. Esto resultó en un ingreso de

21 "Son policías politizadas -y políticas- donde la influencia de la legalidad y el poder judicial es secundaria. La entrada en la organización se realiza desde posiciones laterales y abunda el favoritismo y la corrupción”. (ROBLES, 1997: 17).

22 "Parten del presupuesto de que un personal formado, un equipo moderno y formas organizativas similares a las empresas privadas logran mayor eficiencia y control sobre los agentes. Se piensa que la modernización de la organización es clave y se diseñan cuerpos apolíticos, centralizados, racionales y burocratizados." (Idem: 18).

23 Con varios puntos en común con el modelo racional-burocrático, el modelo profesional se caracteriza por el énfasis en la especialización.

24 El modelo comunitario parte de la idea de que es la sociedad quien mejor puede decir lo que espera de la policía y también es la mejor colaboradora de la policía.

25 Desenvolveu-se, então, uma cultura policial informal, autônoma dos ditames legais ensinados oficialmente, fundamentada em 'lógicas em uso' decorrentes do encontro cotidiano da organização com sua clientela, sem que mecanismos de controle internos e externos surgissem como contraponto. $O$ conteúdo destes padrões culturais ocupacionais informais: a possibilidade de uso da violência como prática cotidiana 'autorizada', especialmente contra os setores da população menos visíveis e menos organizados. (RATTON, 2007: 148). 


\section{Dimensiones histórico-sociológicas de la tortura en comisarías de Brasil: el caso Pernambuco}

personas cada vez con más estudios (en las últimas oposiciones para agente de policía, todos los aprobados tenían al menos una licenciatura o el bachillerato) y en la movilidad geográfica de interesados en las oposiciones originales de los más diversos Estados de la Federación brasileña.

En los años 90 Pernambuco inició una experiencia de "modelo comunitario", pero la PC no se encontraba en el proyecto de Gobierno, que parecía pensar exclusivamente en PM (policía de prevención - trabajo de calle). El propio Gobierno que inició el proyecto de policía comunitaria le puso fin, debido a la resistencia de los policías y a los resultados peores que lo que se esperaba.

Desde hace unos 10 años $^{26}$, algunos Estados, como São Paulo, Rio de Janeiro, Minas Gerais, Espírito Santo y Pernambuco, empezaron a reducir la influencia política, el personalismo de los jefes, la baja burocracia así como la excesiva informalidad, sustituyéndolos por un modelo de gestión dirigido a la obtención de resultados. Tal proceso empezó por la modernización de la Administración Pública general y acabó alcanzando a la policía.

Actualmente, podemos decir que el modelo de la PC de Pernambuco es un modelo híbrido, mezcla de "racional-burocrático", con el "profesional" y con un principio de modelo, fuera de la clasificación de Robles, de "gestión por resultados", en que son creadas áreas de seguridad, con metas para cada policía y en el que los representantes de las dos policías han de explicar al gobernador o sus representantes las razones por lo que han alcanzado, o no, las metas mensuales. Si el problema persiste, los policías pierden sus cargos, cediéndolos a otros policías que se esforzaron por alcanzar tales metas.

Tal modelo fue usado en New York con mucho éxito. En Brasil, también se obtuvieron muy buenos resultados, aunque el modelo fue sólo aplicado para homicidios y otros crímenes violentos en los Estados que contrataron consultorías

$26 \quad$ Esto se escribe en 2012. 
Dimensiones histórico-sociológicas de la tortura en comisarías de Brasil: el caso Pernambuco

para establecer las metas y evaluar los resultados. Esa profesionalización garantizó números de registro de incidencias más fiables y, principalmente, disminuyó la informalidad de la policía, que aún es muy grande. 


\section{Dimensiones histórico-sociológicas de la tortura en comisarías de Brasil: el caso Pernambuco}

\section{Perfil de los entrevistados}

C1: Evangélico, más de 30 años de policía, casado. Permaneció cerca de ocho años sin haber practicado jamás ninguna especie de tortura, pues era contrario a su utilización, hasta que hizo una oposición para el cargo de comisario de policía. Desde entonces, empezó a torturar, pues se sentía presionado para mostrar resultados. Torturó durante unos dos años hasta que se dio cuenta de que la cosa no funcionaba y no daba los resultados esperados, sino que tenía consecuencias negativas. Hace ocho años que no practica y no acepta que nadie practique la tortura donde trabaja. Por su postura de intransigencia ante el ejercicio de la tortura es considerado por algunos colegas como un "radical" o extremadamente "legalista". Ejerció en comisarías del interior, Capital y especializadas. (Entrevista en julio/2010 - 58 minutos).

C2: Unos 50 años, evangélico, casado y casi 30 años como policía. No pernambucano. Actuó antes en comisarías del interior, Capital y especializadas. La policía militar fue su primer trabajo. Presenció torturas, torturó y dio a entender que sigue torturando. Es conocido como "operativo". Preguntado, al final de la entrevista, si quería decir algo más, respondió: Iros a la mierda tú y esa panda de académicos que os hacéis pajas mentales con esos conceptos elitistas de dignidad humana, ¡Hipócritas! ${ }^{i}$ (C2). (Entrevista en abril/2010 - por mail).

C3: Ateo, 40 años, divorciado. No es pernambucano. Más de 15 años como comisario de policía. Se manifiesta en contra de la tortura y jamás la ha practicado, pero presenció una vez la tortura de un preso por policías militares en una prisión del interior del Estado y no hizo nada para que parasen. Actuó en comisarías del interior, 


\section{Dimensiones histórico-sociológicas de la tortura en comisarías de Brasil: el caso Pernambuco}

Capital y especializadas. Es conocido como "legalista". (Entrevista en abril/2010 42 minutos).

C4: Cerca de 50 años y más de 10 años como comisario de policía. Pernambucano, católico y casado. Se manifiesta en contra de la tortura y suele participar en movimientos comprometidos con la defensa de los derechos humanos. Actuó en comisarías del interior, Capital y especializadas. Jamás torturó, ni presenció torturas. Es conocido como "legalista". (Entrevista en abril/2010 - por mail).

CA5: Evangélica. Soltera, de unos 50 años y casi 30 años como policía. No es pernambucana. Actuó en comisarías del interior, Capital, especializadas. La policía fue su primer trabajo y su padre era policía. Jamás torturó y está radicalmente en contra la utilización de la tortura. Conoce comisarios y agentes que la practican. Es conocida como "legalista". (Entrevista en abril/2010 - por mail). Preguntada, al final de la entrevista, si quería decir algo:

La policía debe tener una postura no solo de combate a la tortura, pero de construcción de una nova misión para la policía y de un nuevo papel que tenga más que ver con el policía”. En eso creo que aún estamos a años luz, porque eso solo podría pasar con una participación real de la sociedad. Y la sociedad todavía tiene interés en mantener cierta tolerancia con los actos corruptos y en consecuencia con la tortura. Creo que trabajos de esta naturaleza pueden llegar a contribuir al menos para que se tenga un diagnostico un poco más realista sobre el tema en las instituciones. (CA5). ${ }^{\text {ii }}$

CA6: Católica, pernambucana, soltera, de unos 45 años. Jamás presenció una práctica de tortura. Es contraria al su uso, pero conoce comisarios y agentes que la 


\section{Dimensiones histórico-sociológicas de la tortura en comisarías de Brasil: el caso Pernambuco}

practican. Lleva 12 años como comisaria de policía y actuó en comisarías del interior, Capital y especializadas. Es conocida como una comisaria "legalista". (Entrevista en abril/2010 - 48 minutos).

C7: Tiene casi 40 años, pernambucano, católico y divorciado. Lleva casi 10 años como comisario y trabajó en comisarías del interior, Capital y especializadas. Es considerado un buen policía, pero tenemos información de los entrevistados que nos desvela que ya ha torturado en algunas misiones especiales para cumplir mandatos judiciales. Es conocido como “operativo". (No aceptó ser entrevistado).

C8: Entró en la policía hace más de 30 años y pasó por comisarías del interior, Capital y especializadas. No es pernambucano. Ya tiene derecho a jubilarse, pero no tiene deseo de hacerlo. Es conocido por ser un tipo incorruptible y muy duro con los malos policías. Es conocido también por ser un tipo que no tiene miedo a enfrentarse a ningún otro policía en la institución. Los policías creen que jamás ha practicado la tortura y que jamás aceptaría que alguien lo hiciera delante de él. Es conocido como “extremadamente legalista". (No aceptó ser entrevistado).

C9: Con un poco más de 40 años. Lleva casi 13 años como comisario de policía. Siempre tuvo un discurso contrario a la práctica de la tortura. Pernambucano, católico y divorciado. Ya había ejercido en comisarías del interior, Capital y especializadas. (Entrevista en junio/2010 - 33 minutos).

C10: Casi 50 años, pernambucano, lleva más de 10 años como comisario de policía. Es conocido no sólo por ser un torturador - fue citado por varios de los entrevistados 


\section{Dimensiones histórico-sociológicas de la tortura en comisarías de Brasil: el caso Pernambuco}

que hablaron sobre el tema - aunque todos han señalado que se llevan muy bien con él. Ha ejercido en comisarías del interior y de la Capital. Es muy amable y divertido con los colegas y es considerado como un policía "eficiente". (No aceptó ser entrevistado).

CA11: Casi 50 años y más de 20 años como comisaria de policía. Pernambucana, agnóstica y casada. Es conocida como una persona muy cercana a los movimientos de derechos humanos. Ha actuado en comisarías del interior, Capital y especializadas. (No aceptó ser entrevistado).

C12: Ateo, pernambucano, 45 años y cerca de 14 años como comisario de policía. Entró en la policía porque fue la primera oposición que apareció convocada. Sin familiares en la policía. Había ejercido en diversas comisarías del interior, Capital y especializadas. Preguntado si pretende jubilarse en la policía dijo que sí, pues se considera viejo para volver a estudiar y empezar otra carrera. Es considerado un policía eficiente por sus compañeros. Él afirma ser "contrario a la tortura" pero considera importante usar las amenazas (de tortura) y "unas bofetadas" para obtener buenos resultados. (Entrevista en agosto/2011 - por mail).

C13: 40 años, no es pernambucano, sin religión, casado, sin familiares en la policía, con cerca de 14 años como comisario de policía, con ejercicio en diversas comisarías del interior, Capital y especializadas. Es considerado un policía eficiente por sus compañeros. Preguntado si piensa en jubilarse en la policía, afirmó que sí. Él afirmó también que la elección de hacer una oposición para comisario ocurrió al azar: Sucedió medio de casualidad, al opositar para ingresar en el cuerpo (de policía), buscando estabilidad económica, me acabó gustando la profesión. Preguntándole 


\section{Dimensiones histórico-sociológicas de la tortura en comisarías de Brasil: el caso Pernambuco}

por que renunció a salir, contestó: tuve ganas de salir en algunos momentos, cuando viví momentos difíciles en la Policía y no me sentía valorado lo suficiente. (Entrevista en agosto/2011 - por mail). ${ }^{\text {iii }}$

C14: Católico. No es pernambucano. Con casi 40 años y cerca de 10 años como comisario de policía. Entró en la policía por casualidad, pues en ningún momento en su vida pensó en ser policía. Sin familiares en la policía. Ejerció en diversas comisarías del interior, Capital y especializadas. Preguntado por si pretende jubilarse en la policía dijo que sí, con mucho énfasis. Es considerado un policía eficiente por sus compañeros. Él afirma estar en contra de la tortura, pero la ha practicado varias veces. (Entrevista en enero/2012 - 1 hora y 8 minutos).

C15: Había sido sucesivamente católico, espírita, evangélico. Pernambucano, 47 años y cerca de 10 años como comisario de policía. Entrar en la policía era su gran sueño. Sin familiares en la policía. Ejerció en diversas comisarías del interior, Capital y especializadas. Era abogado antes de entrar en la policía. Preguntado por si pretende jubilarse en la policía dijo que sí, con mucho énfasis. Es considerado un policía eficiente por sus compañeros, aunque algunos lo ven como un sádico. Él tortura desde el día que entró en la policía y parece tener la determinación de seguir torturando hasta su jubilación. Además de ya haber usado animales para torturar los sospechosos, acostumbra a usar prácticas sexuales contra sus víctimas y, siempre utiliza en las torturas a los familiares y esposas de los criminales cuando éstos no colaboran. (Entrevista en enero/2012 - 2 horas e 15 minutos).

A1 - con 27 años, soltero, católico, estudiante de Derecho. Pernambucano, católico, con padre policía, había sido antes policía militar y es agente de policía desde hace tres años. Ejerció en comisarías del interior y Capital y, actualmente había cumplido 


\section{Dimensiones histórico-sociológicas de la tortura en comisarías de Brasil: el caso Pernambuco}

3 años como policía civil. Entró en la policía por influencia del padre: Siempre lo vi y lo seguí como un buen policía. Eso fue creando en mí esas ganas de conocerlo y de cierta manera me identifiqué. No tiene muchas ganas de jubilarse en la policía, pero considera que es una posibilidad. A1 vio la tortura como policía militar y como policía civil; conoce policías que torturaron, punidos o no; él mismo torturó y aunque se muestra contrario a la tortura admite que podría torturar de nuevo. Su entrevista fue una de las más exitosas, pues fue muy rica en detalles. A1 no tenía ninguna dificultad en hablar. Hablaba sin miedos y, en ningún momento demostró arrepentimiento. Al contrario, demostraba pasión por su trabajo y al mismo tiempo una visión crítica. (Entrevista en junio de 2011 - 49 minutos).

A2: con 28 años, 2 de ellos como agente de policía, soltero, sin religión, estudiante de Derecho, (...) fue policía militar durante 5 años, con padre en la policía civil. Entró en la policía porque siempre veía el trabajo de su padre y tenía ganas de hacer lo mismo. Piensa jubilarse en la policía civil, quizá como comisario. Como A1, vio la tortura como policía militar y como policía civil; conoce policías que torturaron, castigados o no; (...) torturó y aunque se considera, hoy, contrario a la tortura admite que podría torturar de nuevo. Su entrevista fue una de las más largas y también muy rica en detalles. A continuación, una pequeña muestra de su entrevista donde él afirmó:

La sociedad hoy, desafortunadamente, ya no es como en los años 60, la policía ya no impone respeto. Si llegas a un determinado lugar y los policías son minoría, en un lugar violento, van a vacilarles, no van a obedecer, porque la policía ya no impone respeto. No es como en Europa o como en Inglaterra que la policía va desarmada... Allí, la sola figura del policía ya impone respeto. En Brasil no funciona así. Si llegas a un determinado lugar en minoría, no vas a ser respetado, tus órdenes no van a ser acatadas. Por eso la policía hoy en día, muchas veces da resultado, desafortunadamente, pero a través del miedo. El delincuente tiene miedo de que el policía eche su puerta abajo, haga daño a alguien de los suyos, que actúe de forma 


\section{Dimensiones histórico-sociológicas de la tortura en comisarías de Brasil: el caso Pernambuco}

violenta. Entonces el entiende eso. Pero el no respeta al cuerpo de policía, la policía es temida. Entonces los policías intentan mantener ese aspecto, porque es mejor ser temido a no llegar al resultado. iv

A2 no tenía ninguna dificultad en hablar. Hablaba sin miedos y demostraba pasión por su trabajo y al mismo tiempo una apurada visión crítica. (Entrevista en julio/2011 -60 minutos).

A3: con 50 años, 27 de ellos como agente de policía, católico, casado, terminó la escuela y entró en la policía buscando la estabilidad del servicio público. Su primer choque fue cuando aún estaba en la academia de policía y tenía que hacer prácticas en comisarías y, en su primer trabajo de campo, un accidente de tráfico, observó que los policías no estaban preocupados en socorrer a la víctima, pues estaban ocupados llevando sus objetos personales. Esa fue la primera vez que escuchó una frase que se repetiría muchas otras veces: "fica quieto novinho que é assim mesmo!" (¡quédate quieto 'novato' pues es así como se hace!). No fue una entrevista fácil, parecía más un interrogatorio. Invitado a hablar en tercera persona o sobre la policía de otro Estado, dijo que no hacía falta, pues estaba tranquilo. Pero, era visible cómo se sentía incómodo de hablar sobre el tema. Hubo un momento que nos recordó que no se utilizaba la palabra tortura, y sí, la frase "tirar serviço" (sacar la información de alguien). O sea, había sospechosos que eran "ruim de serviço" (no hablaban) y los policías hacían "el trabajo" de sacar la información. En ese momento sustituí la palabra tortura por "tirar serviço". Aun así no fue fácil y él confirmó mi impresión de las primeras entrevistas: cuanto más mayor en corporación policial, más difícil sacar informaciones. Esto queda claro cuando él afirma que no hay más tortura en las comisarías de Pernambuco, quizá en algún Estado más retrasado de Brasil. (Entrevista en junio de 2011 - 18 minutos). 


\section{Dimensiones histórico-sociológicas de la tortura en comisarías de Brasil: el caso Pernambuco}

A4: Con 50 años, 29 de ellos como agente de policía, dos licenciaturas (una en Derecho), católico, casado. Cuando salió del ejército entró en la policía. Tiene padre policía. Según él, la razón para entrar en la policía fue la "influencia de mi padre que era policía y también del ambiente militar onde había trabajado antes"”. Trabajó a finales del periodo dictatorial (1964-1984) y dijo que por ser fuerte siempre era llamado para dar palizas a los sospechosos. Al principio no aceptaba y quería salir de la policía, pero la necesidad de sostener la familia le obligó a seguir. Siempre ha convivido con torturadores y durante esos años siempre intentó disminuir el sufrimiento de los sospechosos con actitudes muy sencillas como ofrecer un poco de agua, no "apretar" tanto en los interrogatorios y, incluso ya llegó a discutir con una colega que insistía en dar una paliza a un sospechoso que ya había confesado todo. Es contrario a la tortura, pero dijo que casos de violencia sexual contra niños y viejos él prefiere apartarse del caso para no caer en la tentación de volver a cometer tortura. (Entrevista en junio/2011 - 47 minutos).

No conocíamos a los demás policías que fueron invitados a la entrevista. Tampoco parecía ético y seguro buscar ulteriores informaciones respecto a policías que ya habían manifestado el deseo de no participar. 


\section{Dimensiones histórico-sociológicas de la tortura en comisarías de Brasil: el caso Pernambuco}

\section{Observaciones sobre los entrevistados:}

Antes de iniciarnos en las primeras entrevistas con comisarios teníamos dudas sobre si conseguiríamos sacar de los policías alguna información interesante sobre un tema tan grave y tan secreto entre ellos. Después de las primeras entrevistas con comisarios y de esas últimas entrevistas con los agentes de policía teníamos otra duda: cómo trabajar con tanta información. Cada contestación, o incluso la propia ausencia de ella podría llevarnos por un camino distinto.

Dábamos por sentado que obtendríamos las mejores informaciones justamente de las personas con las que teníamos las mejores relaciones de fiabilidad. Sin embargo, en la práctica hubo algo que nos sorprendió: esto es, en algunas situaciones las mejores informaciones no procedían de las personas más cercanas.

En total seleccionamos a 16 comisarios de los cuales once aceptaron hablar. Desestimamos una de las entrevistas puesto que sabíamos que el individuo mintió, dado que conocíamos su posición y prácticas antes de la entrevista. Requerimos también a 8 agentes, de los cuales 4 hablaron.

Al entrevistarnos con C8, un policía más de 60 años, con gran conocimiento sobre quién es quién en la policía, sin razones para temer nada, pues ya había llegado a todos los puestos y ya tenía derecho a la jubilación, además de no tener preocupaciones, pues posiblemente jamás había torturado a nadie, no tuvimos ningún éxito. La relación de seguridad establecida sobre la buena relación que tenemos y la garantía de sigilo no fueron suficientes para lograr una entrevista con él sobre la tortura. Ante la primera solicitud cambió de tema y cuando insistimos que sería muy importante que él nos ayudara con la entrevista - era una forma de poner el 


\section{Dimensiones histórico-sociológicas de la tortura en comisarías de Brasil: el caso Pernambuco}

componente de la amistad en relieve para obtener su ayuda - él nos contestó que no tenía ganas y nos indicó otro nombre.

La misma situación se dio con Ca11, comisaria con experiencia, con más de 25 años como comisaria, y que ya había pasado por todos los tipos de comisaría y ya había logrado culminar su carrera. También tenemos un fuerte vínculo de amistad y fiabilidad. No obstante, reaccionó como C8 y esquivó la entrevista, incluso cuando apelamos a la amistad y a la necesidad de ayuda.

Algo diferente sucedió con C9 con el que tenemos una buena amistad y que aceptó ser entrevistado, pero mintió sobre hechos que sabíamos reales a través de otras charlas informales con el propio entrevistado. Antes de entrevistarlo, ya habíamos escuchado de él mismo descripciones de torturas practicadas por un investigador de su equipo y de otras situaciones de denuncias de tortura que lo llevaron a Asuntos Internos (la policía de la policía). Cuando lo entrevistamos, aunque no estaba en ningún tipo de investigación por parte de AI o de ninguna otra especie - algo que justificaría una postura contradictoria - él negó todo lo que nos había contado de manera informal. Por lo tanto desestimamos su entrevista.

En otras situaciones, como las de $\mathrm{C} 10$ y $\mathrm{C} 7$, no esperábamos tener mucho éxito. A pesar de que teníamos informaciones seguras que garantizaban que se trataba de torturadores, ellos no aceptaron ser entrevistados. C7 fue muy educado y atento, aunque se puso demasiado nervioso cuando supo la razón de la entrevista. Dijo que tenía mucho trabajo y que cuando estuviera más tranquilo me llamaría para otro encuentro. Cuando pregunté si quería anotar mi número de móvil, dijo que no era necesario puesto él creía que ya lo tenía y él lo conseguiría muy fácilmente. En ese momento tuvimos la certeza de que no volveríamos a hablar con él. Con C10 fue peor. Estaba jugando a las damas con un inspector delante de la comisaría. Fue simpático y educado cuando me vio hasta saber el motivo de mi 


\section{Dimensiones histórico-sociológicas de la tortura en comisarías de Brasil: el caso Pernambuco}

visita. A partir de ese momento su expresión mudó hacia el escarnio, cuando dijo que a los delincuentes sólo resta la paliza ${ }^{\mathrm{vi}}$; y, para el desprecio, cuando dijo que estaba muy ocupado como para conceder una entrevista. Agradecemos y salimos escuchando risas de los dos. No obstante, hemos tenido mucha suerte con todos los demás que nos parecieron muy sinceros, hablaron sin dificultad y con riqueza de detalles.

Durante la entrevista de $\mathrm{C} 1$, cuando se le preguntó si había torturado alguna vez, él hizo un movimiento para que nosotros apagáramos el grabador. Cuando apagamos el grabador él dijo que había torturado, pero no quería grabar eso. Entonces dijimos que íbamos a encender el grabador y sugerimos que hablara en tercera persona, como si estuviera refiriéndose a otro comisario. Él aceptó y la entrevista continuó sin problemas.

Una sorpresa fue el comisario $\mathrm{C} 15$, del que imaginábamos que no iba aceptar ser entrevistado y no sólo aceptó, sino que nos conmovió con sus relatos y con la naturalidad que hablaba de muertes, torturas y justicia. Su discurso es un ejemplo de contradicción. Sus relatos son tan escalofriantes que parecen irreales. Pero, sólo un mitómano conseguiría mentir tan fácilmente, con tantos detalles y contestar a nuestras preguntas de manera inmediata, sin pensar. No obstante, sus resultados no dejan duda de que no es un mentiroso, quizá es un psicópata.

Otro punto interesante fue en el bloque de agentes, pues conseguimos una muestra curiosa: dos de los entrevistados eran policías con tres años de actividad y los demás, con casi treinta años de policía. La mayoría había ingresado en la Organización a finales de la Dictadura (1964-1984) y los otros dos, desde hacía tres años. Todos tenían experiencia en varias comisarías.

Así que usamos la misma trayectoria de las entrevistas con comisarios y tratamos las contestaciones de forma más clara, menos bloques, intentando acercarnos, o no, a las hipótesis esgrimida en la introducción del trabajo. De todas 


\section{Dimensiones histórico-sociológicas de la tortura en comisarías de Brasil: el caso Pernambuco}

maneras las entrevistas integrales fueron anexadas a la Tesis, pues son una fuente muy rica de informaciones que pueden servir a otros investigadores o a un trabajo más profundizado de análisis del discurso.

Los agentes de policía fueron aún más colaboradores y más rotundos en las contestaciones. Sólo hubo una excepción: A3. Diferente del conjunto de comisarios donde buscamos personas conocidas que sabíamos o creíamos que sabían algo sobre la práctica de la tortura, en ese bloque de entrevistados fue elegido de manera aleatoria entre agentes que trabajaban en una guardia extra. Eso quiere decir que ellos venían de comisarías distintas y sólo estaban juntos por coincidencia. Buscamos 2 agentes de hasta 3 años de experiencia en la Policía Civil y 6 agentes con casi 30 años de experiencia en la misma corporación.

En el caso de los agentes de policía es posible decir que las mujeres no compiten con los hombres en la práctica de la tortura, pues ellos la practican directamente, no a través de terceros como los comisarios (dónde es posible encontrar más casos de mujeres que permiten que sus policías torturen principalmente en la modalidad omisión), esto hace que el número de torturadores mujeres sea más pequeño. También hay muchas menos mujeres en el trabajo de calle (en el que se practica la tortura), pues ellas se concentran en actividades administrativas.

Hubo un caso de una agente de policía, con 3 años de trabajo, que era conocida torturadora, y que muchas veces los colegas de equipos, hombres, tenían que calmarla para que no se sobrepasase con sus prácticas. Intentamos establecer contacto con ella a través de su comisario, pero no aceptó. Actualmente ella estaba pasando por un procedimiento administrativo disciplinar - PAD por práctica de tortura. Esto es una buena razón para rehusar hablar del tema.

De los entrevistados que aceptaron hablar la mayoría fue muy amable, atendió prontamente nuestra petición y se expresó con mucha tranquilidad. Antes de 


\section{Dimensiones histórico-sociológicas de la tortura en comisarías de Brasil: el caso Pernambuco}

empezar todas las entrevistas explicamos que tenían por fin la realización de una tesis doctoral cuyo objetivo era investigar el uso de tortura como medio de trabajo de la Policía Civil. Garantizábamos el sigilo absoluto de los entrevistados, que recibirían nombres falsos en el momento de las transcripciones y que cada grabación sería borrada después de ser transcritas. Sólo ese procedimiento podría garantizar la seguridad para que ellos hablaran. La excepción fue A3, pues parecía a disgusto y fue el que menos habló (la duración de su entrevista fue menos de la mitad de la entrevista más corta del grupo). Creemos que por razón de seguridad dividió la entrevista en el pasado y el presente. En el pasado él acepta que la tortura se daba y en el presente la contestación era siempre: no hay, no existe, no conozco. Cómo las contestaciones del presente eran totalmente contradictorias con su propio testimonio decidimos aprovechar solamente las informaciones del pasado, pero sus declaraciones íntegras están en los anexos. Al final de la corta entrevista le preguntamos si quería añadir algo más respecto a la tortura y dijo algo muy significativo:

Lo echo de menos, lo echo de menos. Porque hoy..., voy a ser bien claro, la gente ya no respeta, la gente hoy en día llega a la comisaría creyéndose con derecho, con derecho, aunque esté equivocado. No respetan al policía de guardia, no respetan al comisario de guardia. 'Hable con mi abogado...' Cosas que antes no pasaban... El tío llegaba, y si llegaba aquí y subiese la voz: al calabozo, dos o tres días... Era una lección para que aprendiera... (A3). ${ }^{\text {vi }}$

Resulta interesante subrayar que los entrevistados más jóvenes que legitiman la tortura hablan con entusiasmo de la necesidad de encontrar a los autores de los crímenes, mientras los más viejos la ven como un instrumento de imposición del respeto que los criminales tienen que tener a la policía y del cumplimiento de órdenes.

Quienes opinan así, subrayan como principal estímulo para la disminución de la tortura policial, el ingreso en el cuerpo policial de nuevos profesionales, que son 


\section{Dimensiones histórico-sociológicas de la tortura en comisarías de Brasil: el caso Pernambuco}

menos tolerantes con la tortura. Otra circunstancia que no podemos olvidar sobre esta "nueva generación" de policías es que en su mayoría son personas que buscan un empleo público por su estabilidad (es muy difícil un empleado público sufrir un despido), y no como antes, personas “con vocación” que tenían parientes y amigos en la policía que alimentaban su deseo de ser también policías y, más aún, de parecer "verdaderos" policías.

Esta nueva generación de policías, al contrario, desea salir de la policía y ascender para realizar algún trabajo en el Poder Judicial, pues éste se paga mejor, se trabaja menos y hay menos riesgos. Para conseguir esto no pueden estar recayendo sobre ellos procesos de ninguna especie y quizá de ahí venga su respeto por la legalidad.

Cuando ya dábamos por concluídas las entrevistas ocurrieron dos situaciones: primero, un comisario, C14, nos dijo que tenía informaciones que podrían ser útiles para nuestra tesis y añadió que se sentiría bien hablando con alguien. La segunda fue con el comisario C15 conocido por prácticas de tortura y que no habíamos intentado entrevistar después de la experiencia con C10. Pero lo encontramos durante un curso y, para nuestra sorpresa, él aceptó ser entrevistado y fue muy solícito y educado. El contenido de las dos entrevistas era tan fuerte, pues fueron los primeros en dar detalles de tortura, que decidimos destacar sus discursos, además de sus entrevistas.

Como consideraciones generales de nuestras entrevistas podemos decir que los sentimientos de miedo y al mismo tiempo la necesidad de hablar de los entrevistados quedó muy patente. No podríamos imaginar que escucharíamos tanto y aún iban estar agradecidos por nuestro trabajo. Después, nos impresionó la naturalidad con que se tortura. Más de 14 años como policía no fueron suficientes para prepararnos para lo que descubriríamos. Como policía e investigador de esta tesis vivo la doble sensación de hacer un trabajo relevante para la sociedad y al mismo tiempo, ser visto como un traidor por muchos colegas. 


\section{Dimensiones histórico-sociológicas de la tortura en comisarías de Brasil: el caso Pernambuco}

\section{Marco legal}

A partir de la Segunda Guerra Mundial el asunto de la tortura pasó a ser tratado en el ámbito del Derecho Internacional en razón de los excesos que se habían cometido en las últimas dos grandes Guerras y de la posibilidad de nuevas utilizaciones aún más graves.

A este respecto, fueron hitos importantes la Declaración de los Derechos Humanos, de 1948; la Declaración sobre la Protección de todas las Personas contra la Tortura y Otros Tratamientos o Penas Crueles, Inhumanas o Degradantes, adoptada por la Asamblea General de las Naciones Unidas, en 1975; y la Convención Interamericana para Prevenir y Sancionar la Tortura, en 1986.

Brasil ratificó los dos últimos Tratados, respectivamente, en 28/09/1989 y 20/07/1989. Además, introdujo en la categoría de derechos constitucionalmente protegidos los derechos establecidos en tratados internacionales de los que Brasil sea $\operatorname{parte}^{27}$.

La tortura fue regulada por primera vez a través de la CF del Imperio (1824) y fue largamente tolerada, pues coexistió con la esclavitud. Solo después de la abolición de la esclavitud su uso fue disminuyendo, pero en ese momento la $\mathrm{CF}$ Imperial había sido sustituida por la CF de la República, que ya no mencionaba la tortura.

Ni la desaparición de la esclavitud, ni la exclusión de cualquier referencia al tema en el texto constitucional republicano, entrañaron la desaparición de la tortura. Continuaba siendo practicada en las comisarías y penitenciarías de todo el país. La

$27 \quad$ "\$2 do art. $5^{\circ}$ da CF: Os direitos e garantias expressos nesta Constituição não excluem outros decorrentes do regime e dos princípios por ela adotados, ou dos tratados internacionais em que a República Federativa do Brasil seja parte”. (CONSTITUIÇÃO FEDERAL, 1988). 


\section{Dimensiones histórico-sociológicas de la tortura en comisarías de Brasil: el caso Pernambuco}

única diferencia entre el siglo XIX y el XX fue la progresiva exclusividad del Estado en la práctica de la tortura.

Después de un siglo y medio de la utilización de la tortura, la cuestión retornó al ordenamiento jurídico del país a través de la CF $1988^{28}$, principalmente como reacción a las torturas practicadas algunos años antes por la dictadura militar.

Pero la inclusión en la CF de 88 no garantizó el cumplimiento de la Ley, pues la misma necesitaba de una ley infra-constitucional que estableciera su funcionalidad. Eso sólo ocurriría diez años después, con la Ley 9.455/97 que pasó a tipificar penalmente el delito de tortura en Brasil.

Teóricamente, la tortura dejaría de ser tratada como un mero caso de lesión corporal y pasaría a ser vista como un delito serio que demanda políticas públicas específicas y un mayor rigor contra los practicantes de tal acto. En la práctica, la tortura siguió produciéndose en diversas comisarías y penitenciarías del país como si nada hubiera cambiado.

Después de que la norma estableciera penas severas y de una mayor atención sobre el asunto, la tortura continuó siendo un caso raro de aplicación penal, pues casi nunca llegaba a los tribunales. Y cuando ocurría que alguien era procesado por eso, el proceso, en general, era archivado o reclasificado, juzgándose al torturador por lesiones corporales (que tienen una pena mucho menor).

Además de una legislación específica y de una mención en la CF, Brasil ratificó la Convención Contra la Tortura y Otros Tratamientos o Penas Crueles, Inhumanos y Degradantes de 1984, y la Convención Interamericana para Prevenir y Punir la Tortura, de 1985, respectivamente en 28/09/89 y 20/07/89.

\footnotetext{
28 Constituição Federal de 1988, art. 5o. Inc. III: "ninguém será submetido a tortura nem a tratamento desumano ou degradante”. (...) Inc. XLIII: "a lei considerará crimes inafiançáveis e insuscetíveis de graça ou anistia a prática da tortura, o tráfico ilícito de entorpecentes e drogas afins, o terrorismo e os definidos como crimes hediondos, por eles respondendo os mandantes, os executores e os que, podendo evitá-los, se omitirem".
} 


\section{Dimensiones histórico-sociológicas de la tortura en comisarías de Brasil: el caso Pernambuco}

\section{Conceptos}

\section{Tortura}

El texto más importante del siglo $\mathrm{XX}$ condenatorio de la tortura es la Declaración Universal de los Derechos Humanos, aprobado por la Asamblea General de las Naciones Unidas en 10 de diciembre de 1948, que estableció en su artículo quinto: "Nadie será sometido a torturas ni a penas o tratos crueles, inhumanos o degradantes".

Más adelante el concepto de tortura se clarificaba en textos como la Declaración sobre la Protección de Todas las Personas Contra la Tortura y Otros Tratos o Penas Crueles, Inhumanos o Degradantes de $1975^{29}$ o la Convención Contra la Tortura de $1987^{30}$.

Según el Diccionario Houaiss la tortura sería una: "dor violenta que se inflige a alguém, sobretudo para lhe arrancar alguma revelação; suplício" (HOUAISS, 2001); la Enciclopedia francesa Larousse: "tout acte par lequel une douleur ou des

$29 \quad$ Artículo 1.1: A los efectos de la presente declaración, se entenderá por tortura todo acto por el cual un funcionario público, u otra persona a instigación suya, inflija intencionalmente a una persona penas o sufrimientos graves, ya sean físicos o mentales, con el fin de obtener de ella o de un tercero información o una confesión, de castigarla por un acto de haya cometido o se sospeche que ha cometido, o de intimidar a esa persona o a otras. No se considerarán tortura las penas o sufrimientos que sean consecuencia únicamente de la privación legítima de la libertad, o sean inherentes o incidentales a ésta, en la medida en que estén en consonancia con las Reglas Mínimas para el Tratamiento de los Reclusos.

30 Artículo 1: A los efectos de la presente Convención, se entenderá por el término "tortura" todo acto por el cual se inflija intencionadamente a una persona dolores o sufrimientos graves, ya sean físicos o mentales, con el fin de obtener de ella o de un tercero información o una confesión, de castigarla por un acto que haya cometido, o se sospeche que ha cometido, o de intimidar o coaccionar a esa persona o a otras, o por cualquier razón basada en cualquier tipo de discriminación, cuando dichos dolores o sufrimientos sean infligidos por un funcionario público u otra persona en el ejercicio de funciones públicas, a instigación suya, o con su consentimiento o aquiescencia. No se considerarán torturas los dolores o sufrimientos que sean consecuencia únicamente de sanciones legítimas, o que sean inherentes o incidentales a éstas. (ONU, 1987). 


\section{Dimensiones histórico-sociológicas de la tortura en comisarías de Brasil: el caso Pernambuco}

souffrances aiguës, physiques ou mentales sont intentionnellement infligées à une personne" (Larousse, 2009), pero la mejor definición es la del Diccionario de la Real Academia Española: tortura es el "grave dolor físico o psicológico infligido a alguien, con métodos y utensilios diversos, con el fin de obtener de él una confesión, o como medio de castigo" (RAE, 2009).

La distinción entre el concepto de la ONU y de los diccionarios es principalmente la finalidad y el practicante de la tortura. La ONU prefirió establecer que la tortura era un delito específico, del que sólo el funcionario público, o alguien instigado por aquél, puede ser autor; también estableció que la finalidad es obtener una confesión o castigar a alguien por haber practicado algo. Los diccionarios preferirán, y no podía ser diferente, una interpretación más amplia.

Lo mismo pasó con la legislación de varios países. Mientras en España, Portugal y Alemania seguirán el ejemplo de la ONU, Brasil, Argentina y Francia preferirán un concepto más amplio, extendiendo al particular el delito de tortura.

En este trabajo, como tratamos del uso de la tortura por la policía brasileña, utilizaremos el concepto más estricto: violencia física o psicológica, practicada por funcionario público o quien ejerza su función, con el objetivo de investigar o reprimir la práctica de algún acto.

Esa opción se debe exclusivamente a la especificidad de nuestro tema. Pues no estamos de acuerdo con los especialistas (en general especialistas militantes de derechos humanos) que no aceptan que sea tratado como un delito común y por eso susceptible de ser cometido por cualquier persona. Para nosotros, aunque la mayoría de los casos de tortura sean practicados por funcionarios públicos ${ }^{31}$, la existencia de

\footnotetext{
$31 \quad$ Amnistía Internacional. Revista Bimestral para los países de habla hispana. N. 45, octubrenoviembre de 2000 .
} 


\section{Dimensiones histórico-sociológicas de la tortura en comisarías de Brasil: el caso Pernambuco}

innumerables crímenes de tortura que son cometidos por particulares, en muchos países, justifica su concepto más amplio ${ }^{32}$.

En nuestro caso, la opción elegida tiene la ventaja de evitar discusiones muy genéricas sobre hasta qué punto podríamos considerar un acto como tortura en función del uso demasiado amplio de dicha palabra en lo cotidiano. Por ejemplo, en una discusión sobre las malas condiciones de trabajo, podemos encontrar el uso metafórico de la palabra tortura; o sobre los métodos pedagógicos empleados en determinada escuela también podríamos usar la palabra tortura. Y así sucesivamente.

Además de ser más práctica, pues evitamos un alargamiento excesivo del tema y su consecuente dificultad de estudio, esa restricción también sirve para converger con el uso jurídico, internacional y académico, más usual de esa palabra ${ }^{33}$.

\footnotetext{
32 Hay muchos crímenes de tortura practicados contra trabajadores sometidos a trabajo esclavo, mujeres que sufren violencia sexista y niños que sufren violencia de los parientes o responsables por su guardia.

33 Ulpiano, en el siglo III (aC?): Por quaestio (tortura) hemos de entender el tormento y sufrimiento del cuerpo para obtener la verdad. (...) En el siglo XIII, el jurisconsulto romano dedicado al derecho, Azo, dio esta definición: la tortura es la indagación de la verdad por medio del tormento.(...). Y en el siglo XVII el jurisconsulto dedicado al derecho civil, Bocer, decía: La tortura es el interrogatorio mediante el tormento del cuerpo, respecto a un delito que se sabe que ha sido cometido, tormento legítimamente ordenado por un juez con el fin de obtener la verdad sobre dicho delito". (PETERS, 1987: 12-13).
} 


\section{Dimensiones histórico-sociológicas de la tortura en comisarías de Brasil: el caso Pernambuco}

\section{Producción del discurso}

Entendemos por discurso la producción de un texto en un contexto social. Es decir, los discursos son una construcción social, no individual, y por eso sólo pueden ser interpretados en su contexto histórico - social, y en sus condiciones de producción. El discurso reflejará una visión de mundo necesariamente vinculada a la de sus autores y de su entorno, así como a la de la sociedad en que viven.

La distinción entre la interpretación gramatical y el análisis del discurso es que la primera busca los significados tras las palabras. El segundo, el significado oculto. Las ideologías ${ }^{34}$ e influencias que agregan valor al texto y por eso son imprescindibles para su interpretación. En el análisis del discurso se buscan los elementos verbales y no verbales y las interacciones sociales. En suma, lo importante de los discursos son los significados que pueden tener los significantes a través de las construcciones sociales ${ }^{35}$.

Otro factor fundamental, según Bourdieu es el "habitus", que demuestra que la posición social determina tanto las prácticas en general como las prácticas discursivas en particular de los individuos. Ese mismo "habitus" también puede producir censura sobre tales discursos en razón de las relaciones sociales del individuo ${ }^{36}$.

\footnotetext{
34 "Las ideologías constituyen el marco cognitivo fundamental que organiza nuestros esquemas, argumentos y actitudes. Representan nuestras visiones generales de la sociedad e incluyen los temas, objetivos e intereses más generales que controlan nuestras prácticas sociales". (VAN DIJK, 1980: 210).

$35 \quad$ Pinto \& Galvéz, 1996: 31.

36 Como todo discurso, las lenguas especiales que los cuerpos especialistas producen y reproducen mediante una alteración sistemática de la lengua común, son a su vez, producto de un compromiso entre un interés expresivo y una censura constituida por la estructura misma del campo en el que ese discurso se construye y circula. Más o menos 'conseguido' según la competencia
} 


\section{Dimensiones histórico-sociológicas de la tortura en comisarías de Brasil: el caso Pernambuco}

Silva recuerda que no será la posición social aislada la que determinará las prácticas discursivas individuales, sino todo el contexto social donde está inserto, incluso su posición social, lo que será determinante para el discurso. Además, es a través del discurso que los policías emiten la idea que tienen de los derechos humanos o de la tortura, aunque implícitamente. ${ }^{37}$.

Hay un gran número de términos usados para describir las posibilidades de extraer el significado de un mensaje presente en un texto, o en cualquier otra forma de comunicación. El análisis de contenido y el análisis del discurso son posibilidades de interpretación de textos ${ }^{38}$.

Según Chizzotti (2006), discurso no tiene un significado único. En el lenguaje común puede significar el diálogo entre hablantes; en lingüística, es la forma por la cual los diversos elementos lingüísticos están reunidos para constituir una estructura de significado más amplia que la suma de las diversas partes. En la investigación, es el análisis de un conjunto de ideas, un modo de pensar o un cuerpo de conocimiento esgrimido en una comunicación textual o verbal, lo que el investigador se puede identificar cuando analiza un texto o conversación.

específica de cada productor, esta 'formación de compromiso', para hablar con palabras de Freud, es el producto de estrategias de eufemización, estrategias que consisten en dar forma y en introducir formas, cosas ambas que se producen inseparablemente: esas estrategias tienden a asegurar la satisfacción del interés expresivo, pulsión biológica o interés político (en el sentido amplio del término), en los límites de la estructura de las posibilidades de beneficio material o simbólico que las diferentes forma de discurso pueden procurar a los diferentes productores en función de la posición que ocupan, es decir, en función del lugar que ocupan en la estructura de la distribución del capital específico que está en juego. (BOURDIEU, 1985: 109).

37 (SILVA, 2006: 33).

38 "A análise de conteúdo visa decompor as unidades léxicas ou temáticas de um texto, codificadas sobre algumas categorias, compostas por indicadores que permitam uma enumeração das unidades e, a partir disso, estabelecer inferências generalizadoras. A análise do discurso constitui-se como um tipo de análise que ultrapassa os aspectos da língua no contexto interativo e social em que é prolatada, considerando a linguagem, em última análise, como uma prática social. As práticas de pesquisa, derivadas dessas análises, visam decifrar comunicações transcritas em documentos.” (CHIZZOTTI, 2006: 113-114). 


\section{Dimensiones histórico-sociológicas de la tortura en comisarías de Brasil: el caso Pernambuco}

El análisis del discurso ${ }^{39}$ no puede restringirse a la estructura ordenada de palabras, ni a una descripción o a un medio de comunicación, ni tampoco a una mera expresión verbal del mundo. El análisis de discurso sitúa el sujeto en su entorno social. Según Foucault, es necesario descifrar la genealogía del poder. Otra posibilidad es la de descifrar el discurso en el contexto socio-histórico, considerando que aquél sólo puede ser comprendido si es relacionado con el proceso cultural, socioeconómico y político en los cuales el discurso tiene lugar. El discurso está conectado con las relaciones sociales y es revelador de las posiciones de los interlocutores en su contexto, sólo pudiendo ser comprendido en tanto cuanto se perciben las relaciones de fuerza contenidas en él.

Tal herramienta es aún más importante cuando pensamos en organizaciones tan cerradas como la policía. Pues las personas emplean el discurso para hacer cosas - para acusar, para excusarse, para presentarse de una manera más aceptable, etc. Llamar la atención sobre esto equivale a señalar que el discurso no ocurre en un vacío social. Según Gill ${ }^{40}$, como actores sociales, nosotros estamos continuamente orientándonos por el contexto interpretativo en que nos encontramos y construimos nuestros discursos para ajustarnos a ese contexto. Pues, el análisis de discurso trata la conversación y los textos como organizados retóricamente. A diferencia del análisis de la conversación, el análisis de discurso contempla la vida social como algo

\footnotetext{
39 "Análise de discurso é o nome dado a uma variedade de diferentes enforques no estudo de textos, desenvolvida a partir de diferentes tradições teóricas e diversos tratamentos em diferentes disciplinas. Estritamente falando, não existe uma única 'análise de discurso', mas muitos estilos diferentes de análise, e todos reivindicam o nome. O que estas perspectivas partilham é uma rejeição da noção realista de que a linguagem é simplesmente um meio neutro de refletir, ou descrever o mundo, e uma convicção da importância central do discurso na construção da vida social." (GILL, 2002: 244).

40 "Para tomar um exemplo concreto, alguém pode dar uma explicação diferente do que fez na noite anterior, dependendo do fato de que quem pergunta é sua mãe, seu chefe ou seu melhor amigo. Não se trata de que alguém está sendo deliberadamente fingido em algum desses casos (ao menos não necessariamente), mas simplesmente de que estaríamos dizendo o que parece 'certo', ou o que ‘vem naturalmente’ para aquele contexto interpretativo particular.” (GILL, 2002: 248-249).
} 


\section{Dimensiones histórico-sociológicas de la tortura en comisarías de Brasil: el caso Pernambuco}

caracterizado por conflictos de varios tipos. Como tal, gran parte del discurso está implicada en establecer una versión del mundo ante versiones competitivas. El énfasis en la naturaleza retórica de los textos dirige nuestra atención hacia las maneras en que todo discurso es organizado a fin de tornarse persuasivo (Gill, 2002).

Si alguien lee un artículo, o un libro, su objetivo general será producir una síntesis sencilla e ignorar los detalles, las contradicciones y las imprecisiones. El analista del discurso, busca justamente los detalles, las contradicciones y las imprecisiones. Busca aquello que está más allá de lo que parece ser la idea general. O como diría Stubbs "un problema central para el análisis, es por tanto, la cantidad de sentido indirecto implicada en el discurso: la distancia entre lo que se dice y lo que se quiere decir y las múltiples capas de significado entre el significado proposicional literal de una emisión y el acto que se lleva a cabo en el contexto"41.

$41 \quad$ (STUBBS, 1987: 151). 


\section{Dimensiones histórico-sociológicas de la tortura en comisarías de Brasil: el caso Pernambuco}

\section{BREVES NOTAS HISTÓRICAS SOBRE LA TORTURA}

\subsection{En el mundo.}

Desde los primeros escritos históricos, a partir de la Edad Antigua, se tienen noticias del uso de la tortura en Babilonia, Persia ${ }^{42}$, India, Egipto ${ }^{43}$, Grecia y Roma $^{44}$. Pero es a partir de la Edad Media cuando la tortura empezará a ser usada sistemáticamente como medio de prueba ${ }^{45}$.

Hasta entonces las ordalías (pruebas físicas a las que se sometía a una de las partes contendientes, en la suposición de que el éxito o el fracaso dependían de la

\footnotetext{
42 "Ejecutábase la pena de scaffismo de modo que el condenado fuera apretado entre dos botes iguales entre si, de manera que la cabeza, los pies y las manos se hallaban por fuera; entonces picábansele los ojos y echábase miel y leche encima de la cara y de los miembros, mandando volver entonces el cuerpo hacia el sol. De inmediato el cuerpo era invadido por las moscas, que iban dilacerándolo; y los gusanos derivados de los excrementos del condenado terminaban royéndole los intestinos. Esta horrible pena fue usada en Persia por mucho tiempo. El Rey Mitrídes sufrió esta pena por 17 días.”. (ASÚA, 1950: 269).

43 "Los primeros testimonios de una práctica tolerada de la tortura se refieren al antiguo Egipto: en algunas pinturas demuestra a recaudadores de impuestos golpeando las plantas de los pies de campesinos para obligarles a revelar ocultos almacenes de grano". (LIZANDRA, 1998: 25).

$44 \quad$ (SZNICK, 1998: 21).

45 "Aunque la tortura fue admitida y parcialmente regulada tanto por el Derecho Romano como por más antiguos ordenamientos, la institución fue definitivamente construida por la doctrina italiana de la Baja Edad Media. Después de las fragmentarias reflexiones de los primeros glosadores sobre la tortura, apareció en Bolonia entre 1263 y 1286 una obra anónima y sin título que fue unánimemente denominada y citada como Tractatus de tormentis; la tortura recibía en ella un tratamiento sistemático, examinándose sucesivamente su concepto, sujetos pasivos, grados, efectos, etcétera. Fue el punto de partida de una abundantísima literatura en torno al tema a lo largo de los siglos siguientes hasta finales del XVI (en 1588 publica todavía Farinacio su famosísima Práxis et theoricae criminalis)." (TOMÁS Y VALIENTE, 2000: 94).
} 


\section{Dimensiones histórico-sociológicas de la tortura en comisarías de Brasil: el caso Pernambuco}

intervención divina: los llamados juicios de Dios) eran el medio más adoptado para decidir las cuestiones jurídicas y descubrir la verdad.

Después de una disminución del uso de la tortura, ésta volvería extenderse en 866, pese a desaprobación del Papa Nicolás I que insistía en que fuese sustituida por el juramento sobre la Biblia o por el uso de testigos. Para entonces y sobre todo a partir del siglo XII, con la recuperación de los principios del Derecho Romano imperial aquella se reintroduciría en diversos Estados centralizados (Castilla, Sicilia, Francia $^{46}$ ), esta vez con la anuencia de la Iglesia ${ }^{47}$.

A partir de la Edad Media, la tortura pasaría a ser introducida en los ordenamientos jurídicos como un procedimiento procesal ${ }^{48}$ adoptado para llegar a la verdad y como tal fue usado en el Oriente hasta principios de la Edad Moderna.

Pasando a ser utilizada de forma más sistemática, la tortura llegaría al ápice entre los siglos XIII y XVII, con la Inquisición. Si hasta entonces era aplicada contra esclavos y siervos ahora pasa a ser incorporada al proceso criminal, contra los

\footnotetext{
$46 \quad$ "En Francia, una ordenanza de Luis IX de 1254 permitía la tortura, pero prohibía la tortura de 'gente honesta de buena reputación, aunque sean pobres' sobre la base del testimonio de un solo testigo, la 'media prueba' formal del procedimiento general romano-canónico". (PETERS, 1987: 90).

47 "Em 1244, o Papa Inocêncio IV aprova a legislação penal de Frederico II e, em 1252, em seu Ad Extirpanda, aceita que os 'hereges, sem mutilação e sem perigo de vida podem ser torturados a fim de revelar os próprios erros e acusar os outros, como se faz com os ladrões e salteadores'. É o retorno oficial ao sistema penal romano, fundado na auto-acusação e na confissão do réu”. (SZNICK, 1998: 29).

48 "El momento culminante de la tortura se inicia en el siglo XII, en el que se producen transformaciones jurídicas importantes que implicaron la recuperación y adaptación del cuerpo escrito del Derecho Romano docto. Una de las consecuencias más importantes de estas mutaciones fue que el procedimiento inquisitorial desplazó al procedimiento acusatorio. En lugar del juramento confirmado y verificado del hombre libre, la confesión fue elevada a la cúspide jerárquica en el universo probatorio: los juristas la llamaron la reina de las pruebas. Este reinado dio a la confesión, a diferencia de lo que ocurría en los Derechos griego y romano, un lugar preeminente que explica la reaparición fortalecida de la tortura en el Derecho medieval." (SOLÓRZONO, 2004: 203).
} 


\section{Dimensiones histórico-sociológicas de la tortura en comisarías de Brasil: el caso Pernambuco}

ciudadanos antes inmunes $^{49}$ a tal práctica. Más que eso, la confesión pasó a tener un valor mucho mayor sustituyendo al sistema acusatorio por el inquisidor y en interés de la Iglesia, que valoraba el arrepentimiento del "pecador". La consecuencia fue un aumento de las prácticas de la tortura para obtener la confesión.

Con la llegada del Iluminismo la tortura empieza a ser criticada. Los trabajos de grandes filósofos como Rousseau, Voltaire, Montesquieu, Diderot, contribuyen a retratar la tortura como algo inaceptable. Sin embargo, es Cesare Bonesana, el Marqués de Beccaria (De los delitos y de las penas), y Pietro Verri (Observaciones sobre la tortura) quienes mejor representan a los críticos del uso de la tortura.

No obstante, hay autores que creen que no fue la influencia de los autores citados lo que hizo que monarcas ilustrados cambiasen de opinión, sino la necesidad de modificaciones en el proceso penal, que pasó, para ser más eficaz, a basar la condena en pruebas que respaldaran la convicción del juez, en lugar de fundarla en la confesión. (LANGBEIN, 1976: 36).

Otros procesos como la Independencia de los Estados Unidos y la Revolución Francesa también contribuyeron a la erradicación de la tortura institucional.

A partir del siglo XVIII la tortura comienza a perder su carácter legal, judicial y público y empiezan los procesos que tratarán de derogarla, al menos, en teoría. La tortura fue prohibida en Austria (1776), en Suecia (1734), en Toscana (1786), en Francia (1789), en Hungría (1776), en Prusia (1754). Al inicio del siglo XIX había sido eliminada del procedimiento penal en prácticamente toda Europa

$49 \quad$ "Os homens livres não eram submetidos à tortura, salvo se fossem estrangeiros ou metecos. No entanto registra-se a prática de tormentos em homens livres, em várias ocasiões, quando se tratava de crimes de Estado." (COIMBRA, 2002: 18). 


\section{Dimensiones histórico-sociológicas de la tortura en comisarías de Brasil: el caso Pernambuco}

Occidental. No por mucho tiempo, pues volvería con mucha fuerza a finales del siglo XIX y durante el siglo $\mathrm{XX}^{50}$.

La tortura cuenta con un amplio margen de aceptación popular desde la Edad Antigua hasta finales de la Edad Moderna. Si en la Edad Antigua era normal para los esclavos, en la Edad Media pasó a ser normal para "los malos" y sólo a finales de la Edad Moderna, empezó a ser inadmisible para todos; hoy es, no sólo inadmisible, nos parece, sino bárbara y monstruosa.

Como podemos ver, no siempre la tortura fue vista así. Había sido creada como un método de prueba divino y después, con la progresiva madurez de los juicios estatales, fue introducida en el procedimiento penal en absoluta consonancia con costumbres de cada sociedad en sus respectivas épocas ${ }^{51}$.

Lo que empezó como método de uso policial o del ejército se transformó luego en método procesal. La tortura fue considerada en su tiempo como una modernización del proceso penal, junto con otros mecanismos de prueba y de formalización del proceso $^{52}$. Últimamente ha sido justificada, por algunos que la practican o la aceptan, como una herramienta indispensable en la lucha contra el gran enemigo de la actualidad: el terrorismo.

\footnotetext{
$50 \quad$ "Las más fiables pruebas recientes indican que se utiliza la tortura, oficialmente o no, en un país de cada tres”. (PETERS, 1987: 18).

51 "En el capítulo de su Retórica, Aristóteles da una lista de cinco pruebas 'extrínsecas' que pueden ser usadas en un proceso legal, además de las figuras de la retórica que también pueden ser usadas: las leyes, los testigos, la costumbre, la tortura y los juramentos". (PETERS, 1987: 29).

52 "Así, los aspectos particulares de los procedimientos legales - no sólo la tortura, sino también el concepto de prueba, el carácter de los testimonios y las funciones de abogados y magistrados - surgieron de anteriores costumbres inarticuladas, bien adaptadas a las necesidades de nuevas culturas, pero que también llevaron a estas culturas en direcciones distintas. Es en este contexto donde debemos buscar la aparición de la tortura como un fenómeno definido". (PETERS, 1987: 26).
} 


\section{Dimensiones histórico-sociológicas de la tortura en comisarías de Brasil: el caso Pernambuco}

En el siglo XX hubo dos grandes acontecimientos que marcaron un retroceso en la lucha contra la tortura: la I y II Guerras Mundiales y los hechos que las antecedieron, como algunos movimientos políticos y sus respectivas represiones ${ }^{53}$.

Incluso después de las dos Grandes Guerras, hubo situaciones que sorprendieron a todos como el descubrimiento de la práctica de la tortura por los franceses en Argelia. Eso ayuda a mostrar cómo los discursos pueden ser muy distintos de las prácticas, pues en ese momento no era un país desajustado o un Estado dictatorial bajo algún gobernante trastornado o psicótico el que la practicaba, o como dijo Peters, no "era una importación de países bárbaros no europeos. Era practicada por europeos sobre europeos y no europeos por igual, pese a una legislación que la prohibía y al intento de los reformadores de condenarla." (PETERS, 1987: 194). Lo más "absurdo" es que Francia, formalmente, era una de las naciones más activas en la lucha por los derechos humanos.

En el siglo XXI, la sorpresa ha venido de otro país con fuerte tradición de respeto a los derechos individuales: EUA. Después de los ataques terroristas del 11 de septiembre de 2001 en los Estados Unidos, lo que parecía imposible ocurrió: la reglamentación de la tortura en leyes aprobadas por el Congreso americano.

\footnotetext{
53 "El crecimiento de la policía de seguridad del Estado, la policía política propiamente dicha, es quizá la última causa de la reaparición de la tortura en el siglo XX. Pero cronológica e institucionalmente fue precedida por el segundo de los órganos extrajudiciales del Estado moderno: el militar”. (PETERS, 1987: 160).
} 


\section{Dimensiones histórico-sociológicas de la tortura en comisarías de Brasil: el caso Pernambuco}

\subsection{Brasil}

En Brasil la tortura fue practicada en casi todos los rincones y en las más diversas épocas y situaciones políticas. Incluso antes de que sus colonizadores llegasen allá ya hay registro de que algunas tribus antropofágicas tenían como práctica encarcelar a sus prisioneros, sólo los más valientes y sin miedos, para después comerlos durante un ritual sofisticado de crueldad y humillaciones. Y tanto mayor era el placer, cuanto mayor fuera la resistencia de la víctima para ser abatida, pues, antes que cualquier ritual místico, ese tipo de tortura era una venganza por los hermanos muertos por el enemigo ${ }^{54}$.

Ese ritual de tortura era lo que ocurría con los indígenas capturados por otros indígenas, antes de la colonización, y después continuó ocurriendo con los colonizadores portugueses y otros pueblos, que eran capturados como enemigos y eran torturados hasta la muerte antes de transformarse en comida para quien los capturó $^{55}$.

Por supuesto, la mayoría de los indígenas no eran torturadores o caníbales, pero hay noticias de varias tribus que torturaban con intensidad, como los Tamoios, Tupinambás, Caetés, Aimorés y Goitacás.

\footnotetext{
$54 \quad$ (STADEN, 2008).

55 "De acordo com Staden (e também Léry e Thevet), a vítima ideal era aquela que tivesse sido capturada no campo de batalha. Seu destino passava a pertencer então àquele que primeiro a houvesse tocado durante a luta. Triunfalmente conduzido à aldeia do inimigo, o prisioneiro era insultado e maltratado por mulheres e crianças. Assim que entrava na taba, tinha de gritar: 'Eu, vossa comida, cheguei'.” (BUENO, 2006: 238).
} 


\section{Dimensiones histórico-sociológicas de la tortura en comisarías de Brasil: el caso Pernambuco}

Con la llegada de los primeros europeos a Brasil, también fue introducida la cultura de la tortura ${ }^{56}$, pero ahora ya más "moderna", y ya bien conocida en el viejo mundo para los criminales, traidores, prisioneros de guerras o para las personas consideradas "inferiores" o "no-personas": esclavos, negros, indígenas y blancos sin posesiones, o títulos, o armas. Para esas categorías, y en su tiempo y cultura, la tortura no sólo era permitida, sino también aconsejada como forma de mantener el control.

Y si la práctica de la tortura era normal en Europa y sus colonias, tanto más en Brasil en el inicio de su colonización, que era una tierra poblada por aventureros, presos degradados, indígenas y negros que no aceptaban la esclavitud, traficantes de esclavos y de maderas, todos ellos en un territorio sin ley, sin justicia y sin Estado.

Mientras no había Estado propiamente dicho en Brasil, sino un conjunto de tierras con sus propietarios (capitanías hereditarias) la tortura era utilizada con la misma naturalidad que las muertes, violaciones y esclavización de indígenas y negros, así como otras actitudes inhumanas tan comunes en aquella época, en la que se encontraban por un lado, "donatarios", esto es, "dueños" del territorio brasileño dividido entonces por la Corte portuguesa con el objetivo de extraer el máximo que consiguiesen para la metrópoli; y, del otro lado, una legión de esclavos ${ }^{57}$, obligados a dejar sus vidas y familias para dedicarse a generar riquezas para terceros y ser tratados como animales.

\footnotetext{
56 "Descoberto e ocupado pelos portugueses, o Brasil tornou-se colônia de Portugal, que imediatamente inseriu entre nós sua legislação e costumes.

As penas adotadas pela legislação portuguesa eram pesadas. O crime de moeda falsa era punido com a amputação das mãos e confisco de bens. Os crimes contra a religião católica eram punidos com penas crudelíssimas: o criminoso era queimado vivo depois de se tirar sua língua pelo pescoço.”(BURIHAN, 2008: 55).

$57 \quad$ Entre esas dos categorías bien clasificadas en la estructura social de la colonia "comprime-se o número, que vai avultando com o tempo, dos desclassificados, dos inúteis e inadaptados; indivíduos de ocupações mais ou menos incertas e aleatórias ou sem ocupação alguma. ”(PRADO JUNIOR, 1963: 279-280).
} 


\section{Dimensiones histórico-sociológicas de la tortura en comisarías de Brasil: el caso Pernambuco}

La constante amenaza de invasión por otras naciones que también tenían interés en Brasil, tales como Francia, España, Holanda y Inglaterra, también contribuyeron al incremento de la tortura, pues esa era la pena para los indígenas y aquellos otros que colaborasen con tales enemigos. Todo eso se daba en una tierra donde había más promesas que condiciones mínimas de supervivencia.

Fracasado el primer intento de colonización del Brasil a través de las capitanías hereditarias (iniciadas en 1534) y sujeta a perder tan prometedor territorio para sus vecinos europeos, la Corte portuguesa resuelve retomar para sí parte de la administración de la Colonia y crear un Gobierno General, disminuyendo el poder de las capitanías y haciendo el primer intento de centralización del poder en la colonia.

Este nuevo modelo podría causar algunos cambios en relación con la práctica de la tortura a la vez que ponía frenos al poder punitivo de los colonos. Sin embargo, el nuevo Gobierno sólo pretendía interferir en casos excepcionales, evitando así situaciones de inestabilidad derivada de un uso excesivo de fuerza por parte de los propietarios de tierras, pero al mismo tiempo, buscando no oponerse a los encargados de la administración de justicia en sus respectivas capitanías. Eso cuando ellos no eran los responsables de los abusos, como fue caso del obispo Sardinha $^{58}$.

\footnotetext{
$58 \quad$ Uno de los casos de tortura relatado por los historiadores durante el primer Gobierno General llama la atención en razón de quién lo cometió: el primer obispo del Brasil: Sardinha. "No mesmo dia em que proferiu o sermão contra D. Álvaro da Costa - $1^{\circ}$. de novembro de 1553 -, o bispo chamou até sua casa e espancou violentamente com uma vara os 'memoristas' (ou capelães de ordens menores) Bastião Pereira e Luís Barreiros, que ele mesmo nomeara. Não se sabe o motivo da surra, mas Bastião Pereira 'esteve à morte, que lhe apareciam os miolos', conforme o relato de Duarte da Costa, confirmado pelo do 'físico' Jorge Fernandes, chamado para tratar o ferido".(BUENO, 2006: 207).
} 


\section{Dimensiones histórico-sociológicas de la tortura en comisarías de Brasil: el caso Pernambuco}

A propósito, el obispo Sardinha fue uno de los que fueran torturados y devorados por indígenas antropofágicos (Caetés), cuando su buque naufragó en la costa del Noreste de Brasil ${ }^{59}$.

¿Fue más violenta la tortura en Brasil que en otras partes del mundo? Creemos que no ${ }^{60}$. Incluso hay relatos que dan cuenta de la preocupación de la Corte por el exceso de violencia ${ }^{61}$. El contexto en que se practicó fue peculiar y eso afecta a los métodos, instrumentos y prácticas, pero el carácter 'punitivo', 'educador' o 'investigador' alcanzado a través de medios aflictivos es el mismo en otras partes del mundo.

Es evidente que los colonos tienden más a la práctica de la tortura, practicándola con mayor intensidad debido a los conflictos derivados de los disturbios de los indios y los negros, que se resisten a la esclavitud y, por otro lado, ya que el pueblo, cada vez más numeroso, carece de condiciones mínimas de supervivencia.

Además el período colonial se caracterizó por la ocupación casi exclusivamente rural, en la que el colono está aislado en su propiedad sin ayuda del Estado, incluso porque éste no existe y sus vecinos están muy lejos. Eso promueve un control y represión aún mayores sobre los esclavos y empleados, que son muchos

$59 \quad$ Se cree que el obispo Sardinha ha muerto no por valor sino por el odio que los indios Caetés profesaban a los portugueses, ya que fueron muy perseguidos por el establecimiento de las relaciones comerciales con los franceses, independientemente de las prohibiciones de la Corte lusa. Y en este caso particular, la tragedia del obispo Sardinha fue mayor, porque su vestimenta y comportamiento, además del intento de los demás miembros del naufragio para protegerlo fueron los que, en última instancia, acabaron por denunciar su importancia y valor en tal expedición.

60 Tal vez sea innecesario añadir que los malos tratos empleados con los esclavos no eran una práctica exclusiva de los señores portugueses. El viajante francés Froger, que visitó Bahía en 1696 y describió las crueldades allí infligidas a los esclavos, subrayaba: "Embora tudo isso seja bastante mau, o tratamento que lhes dão os espanhóis e os ingleses é ainda mais cruel.”. (BOXER, 2000: 33). 61 "Según el historiador Charles Francis, 'la Corona intentó, en diversas formas, fomentar la integración de los indígenas y evitar el etnocidio (leyes en 1570, 1588, 1596, 1605 y 1611), el proceso de colonización, sin embargo, implica en la muerte de los indígenas, su despojo y aculturación’". (DA SILVA, 1990: 40). 


\section{Dimensiones histórico-sociológicas de la tortura en comisarías de Brasil: el caso Pernambuco}

y están siempre insatisfechos, considerándose la tortura más "necesaria" y tornándose más frecuente y visible. No nos podemos olvidar de que la ausencia de un Estado implicaba la falta de control incluso sobre los habituales controladores que eran los colonos.

En 1603 entraban en vigor en Brasil las “Ordenações Filipinas” hasta 1830, cuando fueron sustituidas por "Código Criminal do Imperio". La tortura estaba prevista en el Título CXXXIII del Libro $\mathrm{V}^{62}$.

La tortura se aplicaba a los negros y los indios para que aceptasen la esclavitud, y fue utilizada contra los delincuentes como medio de venganza y disuasión. En tales condiciones los severos castigos fueron vistos como el único medio de que los colonos no perdieran el control, y sus propias cabezas, en un entorno sumamente hostil ${ }^{63}$.

62 Titulo CXXXIII, Libro V: "Não se pode dar certa fórma quando e en que casos o preso deve ser mettido a tormento, porque pode ser contra elle hum só indicio, que será tão grande e tão evidente, que baste para isso convem a saber, se elle tiver confessado fóra do Juízo, que fez o malefício, porque he accusado, ou houver contra elle huma testemunha, que diga que lho vio fazer, ou fama publica, que proceda de pessoas de auctoridade e dignas de fé, ou se o preso se absentou da terra polo dito melefício, antes que delle fosse querelado, con outro algum pequeno indicio. E poderão ser contra elle muitos indícios tão leves e fracos, que todos juntos não bastarão para ser mettido a tormento; por tanto ficará no arbítrio do Julgador, o que verá bem, e examinará toda a inquirição dada contra o preso". (PIERANGELI, 1983 :208).

63 Otras capitanías han sufrido de levantamientos indígenas contra los abusos de los colonos: islotes (pertenecía a Jorge de Figueiredo Correia, tesorero del Reino) había sido atacado por los indigenas Aimorés; Santo Tomé (que pertenecía al capitán Pero Burton) había sido destruida por los indígenas Goitacás y el "donatario” de Bahía, con sus colonos, fueran asesinados por los indígenas Tupinambás. Así como “Na Bahia, Pernambuco e Sergipe d'El-Rei, particularmente junto ao rio São Francisco, a 'Guerra do Gentio' começa no início do século XVII e estende-se até a segunda metade do século XVIII, com ataques vitoriosos de índios contra as vilas de Cairu, Jequiriçá, ilhéus e Maragojipe”. (DA SILVA (a), 1990: 40). 


\section{Dimensiones histórico-sociológicas de la tortura en comisarías de Brasil: el caso Pernambuco}

Para tener una idea de lo que representaba vivir en Brasil en el inicio de la colonización, basta observar que la condena de un preso en Portugal a una pena de destierro a Brasil se comparaba a la pena de muerte ${ }^{64}$.

La percepción de los que llegaron allí sobre la animosidad de la población era bastante clara en diversos relatos que dan cuenta de la agresividad o salvajismo de los habitantes de Brasil en aquellos tiempos.

Al contrario de lo que ocurrió con la colonización española en América, los portugueses no se preocuparon, al menos en el primer momento, de reproducir el modelo que existía en la metrópoli. Su deseo era meramente de explotación de materias primas y eso retrasaría los cambios sociales, tales como la urbanización, el fin de la esclavitud y del uso explícito de la tortura. Igualmente se frenó la circulación de nuevas ideas o discusiones de la otra parte del mundo ${ }^{65}$, con el fin de evitar motines y sublevaciones.

Es verdad que al menos en el plano formal los mismos principios vigentes en Portugal fueron, poco a poco, implantados en Brasil, para lo bueno y para lo malo. Portugal puso las bases del desarrollo de las más diversas instituciones brasileñas, no solo de la Justicia, sino también del modelo de Estado, educación, sistema político, religioso, es decir, definió como sería el país los próximos siglos.

El problema es que esa implantación del nuevo Estado va a ocurrir justo cuando era más visible la decadencia de Portugal, por encima, cada vez más envuelto en la penumbra de la Contra-Reforma. Eso significaba que el Estado que iba a surgir

64 "Dos territórios de exílio, o Brasil, era, ao menos de inicio, conhecido como o mais temível. Condenados reincidentes, já enviados para Goa ou Angola, ao se tornar um estorvo naquelas colônias, acabavam seus dias na América portuguesa”. (BUENO, 2006: 67).

65 "Os entraves que ao desenvolvimento da cultura intelectual no Brasil opunha a administração lusitana faziam parte do firme propósito de impedir a circulação de idéias novas que pudessem pôr em risco a estabilidade de seu domínio. E é significativo que, apesar de sua maior liberalidade na admissão de estrangeiros capazes de contribuir com seu trabalho para a valorização da colônia, tolerassem muito menos aqueles cujo convívio pudesse excitar entre os moradores do Brasil pensamentos de insubordinação e rebeldia”. (HOLANDA, 95: 121). 


\section{Dimensiones histórico-sociológicas de la tortura en comisarías de Brasil: el caso Pernambuco}

preservaría, entre otras cosas, el peor de los principios del mundo ibérico: una sociedad desigual, rígidamente jerarquizada y dividida de acuerdo con la categoría social de pertenencia ${ }^{66}$.

Otro factor significativo para comprender la dinámica de la violencia en Brasil en sus tres primeros siglos es entender el papel que la Compañía de Jesús ejerció en Portugal y en Brasil. Para el bien de los indígenas a quienes intentó proteger del afán esclavista de los colonizadores, pero por otro lado esto fue en detrimento de la sociedad al alejar los ideales renacentistas ${ }^{67}$.

¿Quién estaba sujeto a sufrir tortura? Como regla general y casi absoluta, cualquier persona que atentase contra los intereses de los "donatários" y colonos, y aquellos que no pertenecieran al mundo de la Corte, de la Iglesia, o no fueron nobles y oficiales. Pero la gran mayoría eran los negros y los indígenas, que tuvieron como principales enemigos a los dueños de esclavos y los "Bandeirantes", que para atender la gran demanda de mano de obra esclava, "usurparam os territórios indígenas,

66 “Os crimes eram punidos de acordo com a 'qualidade' do infrator fosse ele um 'peão' ou um 'fidalgo'. Conforme as Ordenações Manuelinas, 'peões' (ou 'homens a pé', que não podiam servir ao rei a cavalo, como os 'cavaleiros') eram pessoas de 'baixa condição'. A 'pena vil' (pena de morte) e os açoites (em geral executados en público, nos pelourinhos) estavam reservados quase que exclusivamente a eles.

Acima dos peões, escalonavam-se as pessoas de 'maior condição': escudeiros, cavaleiros, vereadores, magistrados, escrivães - vários deles 'fidalgos' ('filhos de algo'), tidos como 'gente limpa e honrada' e, portanto, livres de açoites e da condenação à morte (a não ser em casos excepcionais). A ascensão social não propiciava, portanto, apenas melhores condições de vida: representava também a obtenção de una série de privilégios jurídicos, além, é claro, da isenção de impostos”. (BUENO, 2006: 58-59).

$67 \quad$ "Sem livros, sem universidades, sem imprensa e sem debates culturais - em sintese, sem a diversidade e o frescor do humanismo renascentista. 'A inteligência brasileira viria a constituir-se submetida à direção exclusiva da Companhia de Jesus, sob a égide da Contra-Reforma e do Concílio de Trento', diagnosticou o crítico Wilson Martins em sua História da Inteligência Brasileira. 'Esse desejo de perpetuar a ignorância (...) condicionaria as perspectivas mentais do Brasil por três séculos." (BUENO, 2006: 76-77). 


\section{Dimensiones histórico-sociológicas de la tortura en comisarías de Brasil: el caso Pernambuco}

capturaram milhares de índios, arrasaram aldeias, destruíram etnias e favoreceram a difusão de epidemias"

Es decir, la tortura era un medio moral y legalmente aceptado para "hacer justicia", mejorar la economía y obtener control social. Y no podemos olvidar: que esto contó con todo el respaldo de la Iglesia y la Ley.

Justamente cuando la tortura iba a ser suprimida del procedimiento penal en diversos países del mundo occidental ${ }^{69}$, llega el cerco religioso de la ContraReforma, impidiendo el desarrollo y asimilación de las ideas liberales y humanistas que surgirían en el resto de Europa $^{70}$, reintroduciendo la tortura con todo rigor.

Con una economía destruida, sin población ni recursos suficientes para administrar sus colonias, Portugal era cada vez más dependiente de esclavos para explotar las minas y sus plantaciones, contribuyendo esta realidad a la perpetuación de la tortura a gran escala, promovida contra los esclavos $\mathrm{y}$, peor aún, imposibilitando su posterior integración a la sociedad, después de liberados ${ }^{71}$.

$68 \quad($ KOK, 2008: 24).

69 "Em fins do século XV, a Inquisição arrefecia em quase toda a Europa, quando foi remodelada e se estabeleceu na Espanha, em 1478. A partir de então, o tribunal iria adquirir importância crescente e rigor extremo, especialmente após a expulsão dos judeus da Espanha, em 1492. Em Portugal, no entanto, o processo de instalação do Santo Ofício estava destinado a ser longo e moroso. O principal motivo da controvérsia era o desejo da Coroa portuguesa de possuir um tribunal similar ao espanhol - proposta constantemente negada por Roma." (BUENO, 1999: 238239).

$70 \quad$ "Além de ter sido o último país europeu a acabar com a Inquisição, como já se disse, Portugal foi também o derradeiro a abolir o tráfico de escravos e a assegurar a liberdade de expressão e os direitos individuais. 'Em Portugal não há ciência, nem há política, nem há economia, nem há educação, nem há nobreza e não há corte', escreveu o diplomata português José da Cunha Brochado, inconformado com a comparação que ele próprio fazia entre os hábitos da corte portuguesa e dos outros palácios monárquicos que havia conhecido na Europa. 'As letras estão desterradas; nos conventos só se sabe rezar o ofício divino"'. (GOMES, 2007: 62-63).

$71 \quad$ "Subordinados e aviltados pela conquista, pelo regime colonial e pelas formas de trabalho compulsório a que se viam submetidos, os índios e negros eram percebidos como 'inferiores' pelos colonizadores. com o tempo, num processo heterogêneo em seus ritmos e alcances segundo as regiões, deu-se a transferência da percepção de tal inferioridade do índio vencido e do negro escravo às etnias indígena e africana como tais. O sistema de estratificação sócio-étnica resultante, 


\section{Dimensiones histórico-sociológicas de la tortura en comisarías de Brasil: el caso Pernambuco}

A partir del siglo XVIII el número de negros, mestizos e inmigrantes era muy superior al de los colonos y la posibilidad de levantamientos y revueltas era motivo constante de amenaza para la élite dominante, principalmente a finales del siglo XVIII e inicios del siglo XIX, momento en el que los movimientos populares empezaron a ser reforzados por grandes propietarios de tierras.

Además, a partir del siglo XVIII hubo una verdadera explosión demográfica de pobres libres (principalmente inmigrantes), negros y mestizos que alimentaba el miedo de los dominadores a la masa de dominados. De ahí que, según Cardoso, "continuava a existir, nos costumes e nas leis, una estratificação social de base étnica" 72 . La exclusión social era "legítima" (legal) en la sociedad brasileña al menos hasta 1773, cuando fue promulgada una "Carta-ley" para revocar el principio de la "pureza de sangue"73.

El traslado de la Corte portuguesa a Brasil supuso un gran salto hacia el desarrollo. No es que la metrópoli estuviera muy desarrollada, pues hay quien afirma que en aquella situación estaba casi en una situación tan de atraso como la colonia, pero la presencia de la Familia Real exigía cambios y creación de instituciones que ayudaran a transformar el Estado brasileño, frente al conglomerado de capitanías existente hasta entonces. $^{74}$

ao adquirir sanção legal, tornou-se importante instrumento de justificação ideológica do trabalho forçado e de perpetuação da ordem social em vigor - em especial barrando o acesso a índios, negros e mestiços de certas profissões, vantagens sociais e regalias. Serviu, assim, de elemento reprodutor do sistema colonial de poder e das relações de produção existentes". (CARDOSO (a), 1990: 77).

72 CARDOSO (b), 1990: 107.

73 "Impuros eram os cristãos-novos, os negros, mesmo quando livres, em certa medida os indios e as várias espécies de mestiços. Desse princípio decorria a impossibilidade de ocupar cargos, receber títulos de nobreza, participar de irmandades de prestígio etc.(...)existia um corte separando pessoas de não pessoas, ou seja, gente livre dos escravos, considerados juridicamente como coisa". (FAUSTO, 2002: 31).

74 "Às vésperas da chegada da Corte ao Rio de Janeiro, o Brasil era um amontoado de regiões mais ou menos autônomas, sem comércio ou qualquer outra forma de relacionamento, que tinham como pontos de referência apenas o idioma português e a Coroa portuguesa sediada em Lisboa, do 


\section{Dimensiones histórico-sociológicas de la tortura en comisarías de Brasil: el caso Pernambuco}

Con la Corte en Brasil se produjo también la creación de muchas de las instituciones que ya en aquella época caracterizaban el intento de establecer un Estado moderno, tal como la policía y la justicia. Sin hablar de que, con el plan de expansión territorial fracasado y siendo fugitivo de su propio reino, no quedaba otra alternativa al rey portugués, sino "mudar o Brasil para reconstruir nos trópicos o sonhado Império Americano de Portugal. Nesse caso, as novidades começaram a aparecer num ritmo alucinante e teriam grande impacto no futuro do país"75.

Otro factor importante fueron las convulsiones y rebeliones que contribuyeron al crecimiento de la amenaza para la élite dominante, pues los indígenas sublevados (la última revuelta había sido la de los indígenas botocudos en 1809) iban dando lugar al contingente de cautivos que, sumados a los negros libertos, mulatos y mestizos, constituían dos tercios de la población brasileña ${ }^{76}$.

En Brasil ya se habían producido algunas situaciones peligrosas. En la Revuelta de los Alfaiates, en Salvador, a mediados de 1798, hubo manifestaciones públicas exigiendo el fin de la esclavitud e igualdad para todos ${ }^{77}$. Fuera de Brasil había también noticia de experiencias más traumáticas, como la ocurrida en 1794, cuando una revuelta de negros produjo una carnicería de blancos en las Antillas Francesas, actual Haití.

outro lado do Oceano Atlântico. 'Cada capitania tinha o seu governante, sua pequena milícia e seu pequeno tesouro; a comunicação entre elas era precária, sendo que geralmente uma ignorava a existência da outra', assinalou o naturalista francês Auguste Saint-Hilaire, que percorreu o país de norte a sul entre 1816 e 1822". (GOMES, 2007, 120-121).

75 (GOMES, 2007, 215).

76 "Tratava-se de uma situação insustentável e potencialmente explosiva. O pavor das rebeliões de escravos tirava o sono das famílias brancas, abastadas e bem-educadas" (GOMES, 2007: 136137).

77 "Os mais radicais pregavam o enforcamento de parte da elite branca de Salvador. A repressão do governo português foi imediata e duríssima. Quarenta e sete suspeitos foram presos, dos quais nove eram escravos. Três deles - todos mulatos livres - acabaram sendo decapitados $e$ esquartejados. Pedaços de seus corpos foram espetados em estacas pelas ruas da Capital, onde ficaram até se decompor totalmente". (GOMES, 2007: 137). 


\section{Dimensiones histórico-sociológicas de la tortura en comisarías de Brasil: el caso Pernambuco}

En 1817 hubo un levantamiento en Pernambuco, Revolta Republicana, que fue duramente reprimido, pero que sería seguido por muchos otros: Conferência do Equador (1824), con la ejecución de sus principales líderes e igualmente la Setembrada (1832), y, la Praieira (1848); también en el Nordeste, la Sabinada en Bahia (1837); en el Sur, la Revolução Farroupilha (1832); en el Norte, el levantamiento de los indígenas, esclavos y pobres del Grão-Pará, Cabanos (1831); en el Norte, la Balaiada en Piauí y Maranhão (1839); en el Sureste, la Revolta Liberal, en Minas Gerais (1842).

En esos momentos de convulsión social personas hasta entonces libres de ser sometidas a torturas u otras formas de violencia, no escapaban a ellas, como ocurrió con los líderes locales del Norte y Nordeste brasileños ${ }^{78}$, que optaron por ponerse del lado de Portugal y contra los que propugnaban la independencia del Brasil.

Aunque el azote fuese aplicado exclusivamente a los negros y la ejecución y la tortura fuesen penas para los habitantes considerados socialmente "indeseables", incluyendo, por supuesto, los negros, había una excepción para los crímenes de traición política, donde tales penas alcanzaban a cualquiera que fuera considerado enemigo. En ese sentido, algunas de las prácticas de tortura utilizadas en Portugal ${ }^{79}$ desde la Edad Media fueron llevadas a Brasil y usadas siempre que se consideró necesario reafirmar el poder del Rey o, posteriormente, del Emperador Pedro I.

\footnotetext{
78 "Indistintamente, liberais, unionistas ou não, foram perseguidos por não aceitar ordens de Grenfell, resultando num saldo de mais de 1.300 vítimas, dos quais 252 mortos por sufocação por cal virgem lançada no porão do brigue Palhaço, onde estavam aprisionados por ordem de Grenfell'. (MONTEIRO, 1990: 119).

79 "Transplantado para a colônia brasileira, o suplício judiciário incluía mutilação física, marcação com ferro em brasa, açoite e esquartejamento. Foi aplicado sem dó nem piedade sempre que houve um bom motivo (do ponto de vista da Coroa portuguesa). Seria usado contra Tiradentes, na Conjuração Mineira, contra os líderes da Revolta dos Alfaiates da Bahia e em inúmeras outras pequenas rebeliões regionais”. (GOMES, 2007: 138).
} 


\section{Dimensiones histórico-sociológicas de la tortura en comisarías de Brasil: el caso Pernambuco}

Diez años después de la llegada de la familia portuguesa, la ciudad de Río de Janeiro ya se había duplicado su población (cerca de 120.000 habitantes), pero con un problema: la mitad de esos habitantes eran esclavos. $\mathrm{Y}$ en ese escenario tres aspectos incomodaban bastante a la élite brasileña: el aumento de los crímenes ${ }^{80}$; la contención de los esclavos y el mantenimiento del orden en las ciudades.

En este cuadro y con la presencia de la Corona fueron establecidas las primeras formas de policía en Brasil, incluso con la sustitución gradual de la Ley penal utilizada en la Colonia (Libro $V$ del Código Filipino), que además de concentrar todos los poderes en los agentes de la Corona, reconocía la tortura como instrumento judicial de obtención de confesiones y entre los castigos previstos contemplaba la mutilación física, la marca a hierro candente, descuartizamientos y azotes.

Hasta ese momento, debido a la ausencia de un poder central y una comunicación fluida entre las ciudades, en la inmensa mayoría del territorio la ley era "creada", el "proceso" decidido y la pena aplicada, todo por una única persona: el líder local que mantenía su milicia y su poder en la área que administraba.

En 10 de mayo de 1808 fue creada en Rio de Janeiro la "Intendência Geral de Polícia da Corte" (mezcla de ayuntamiento con secretaría de seguridad pública) que empezaría a limitar el poder de los particulares y sus milicias y pasaría a dar los primeros pasos para la creación de fuerzas policiales modernas.

Para el primer "Intendente Geral de Polícia”, el abogado Paulo Fernandes Viana, desembargador y ouvidor de la Corte, uno de los grandes obstáculos para cumplir fielmente sus tareas (urbanización, iluminación pública, basura, condiciones sanitarias, malas costumbres, resolver peleas y problemas con los esclavos, en fin,

80 "A criminalidade atingiu índices altíssimos. Roubos e assassinatos aconteciam a todo momento. No porto, navios eram alvos de pirataria. Gangues de arruaceiros percorriam as ruas atacando as pessoas a golpes de faca e estilete. Oficialmente proibidos, a prostituição e o jogo eram praticados à luz do dia”. (GOMES, 2007: 228). 


\section{Dimensiones histórico-sociológicas de la tortura en comisarías de Brasil: el caso Pernambuco}

prácticamente todo) era la presencia masiva de esclavos. Con sectores que oscilaban entre uno y dos tercios de la población general, los esclavos representaban una amenaza pronta a estallar, como ya había ocurrido en la Isla de Santo Domingo (Haití).

Los esclavos eran un problema no sólo por la potencial amenaza física a sus dueños, sino también por el perjuicio económico que podrían causar si paraban de trabajar. También obstaculizaban la pretensión de atraer empresas e inversiones extranjeras para un territorio con tantos problemas de enfermedades y epidemias, revueltas, robos y violencia, que eran atribuidos a ellos.

Para tener una idea de la tensión de esa relación basta pensar que sin los esclavos la economía no podría florecer, pero con ellos, los señores estaban obligados a convivir con el miedo diario de que las víctimas se transformasen en "verdugos" $"$.

Viana acreditaba que el azote era la forma encontrada para mantenerlos sobre control, pero al mismo tiempo, temía que la exageración en la aplicación de tal medida pudiese causar un efecto contrario y provocar revueltas o convulsiones.

Cuando los negros cometían algún delito sus dueños mandaban azotarlos en la plaza pública. "Pequenos furtos e porte de armas, como navalhas, eram reprimidos de forma severa. Um escravo recebia de duzentos a trezentos açoites por ser encontrado com navalhas ou lutando capoeira" $"$.

\footnotetext{
81 “' 'Os escravos são sempre inimigos naturais de seus senhores: eles são contidos pela força e pela violência', afirmava José C4 Miranda, autor de um panfleto que circulou no Rio de Janeiro em 1821 com análise da situação política do Brasil e de Portugal. 'Em toda parte onde os brancos são muito menos que os escravos e onde há muitas castas de homens, uma desmembração [...] pode estar ligada com a sentença de morte e um batismo de sangue para os brancos, como aconteceu em São Domingos e poderá acontecer em toda parte em que os escravos forem superiores em força e número aos homens livres'”. (GOMES, 2007: 231).
}

82 (GOMES, 2007: 231). 


\section{Dimensiones histórico-sociológicas de la tortura en comisarías de Brasil: el caso Pernambuco}

Si encontraban un negro silbando el ritmo de la capoeira o con cintas amarillas y encarnadas (símbolo de los capoeiristas) o con instrumentos musicales usados en la capoeira ya era suficiente para apresarlo y azotarlo. La capoeira era fuertemente reprimida por tratarse de un acto contrario a las costumbres predominantes y por estar ligada a constantes peleas y violencias entre los practicantes de grupos rivales.

Para tener una idea del contexto en que esos castigos eran adoptados, un esclavo era comercializado por el valor que él podría reportar a su dueño. Un esclavo valía cerca de tres veces el valor de un burro de carga o caballo.

Los principales instrumentos de tortura eran de tres categorías: inmovilización, usados para capturarlos o contenerlos; restrictivos, usados para evitar que comiesen caña, rapadura o piedras preciosas; investigadores, para obtener confesiones; marcadores, para revelar, físicamente, si era un esclavo fugitivo, criminal. Pero de lejos los azotes (latigazos) eran los más usados, tanto que el instrumento de trabajo de los guardias reales, al contrario del tradicional sable militar era un látigo de mango largo que podía ser usado como porra o látigo.

La inmensa mayoría de los presos eran esclavos o negros libertos y la principal razón de su aprisionamiento estaba, casi siempre relacionada con su presencia sospechosa en las calles cuando no estaban trabajando. Había también presos por hurto; otros calificados de "agresivos", porque tiraban piedras a los blancos; otros porque peleaban entre sí.

Pero los negros representaban para la élite dominante el miedo de que se sublevaran; la vergüenza ante los europeos por el mantenimiento de la esclavitud, cuando ésta empezó a ser condenada en el otro continente, pero también la supervivencia del sistema que mantenía tal élite. O como dijo un ministro de Justicia, 


\section{Dimensiones histórico-sociológicas de la tortura en comisarías de Brasil: el caso Pernambuco}

"o problema do controle dos escravos na cidade era que 'esta propriedade não se guarda, anda pelas ruas" $" 83$.

Por eso, cuando los esclavos no estaban trabajando, la élite quería olvidarse de que existían y la policía administraba el conflicto social, justificando la represión de los negros como forma de mantenimiento del orden y tranquilidad pública.

Para el intendente Viana la tortura era aceptable y necesaria, pero no debía ser hecha en la plaza pública, pues eso comprometía la imagen de la Corte ante tantos extranjeros que circulaban en aquella época por (...) Río de Janeiro. También se preocupaba por los excesos punitivos, que podrían desencadenar revueltas, por lo que determinó que los azotes serían administrados en lugares cerrados y bajo la supervisión de la intendencia general de policía ${ }^{84}$. Es decir, la tortura empezaba a pasar de las manos de los dueños de esclavos a las manos del Estado, más concretamente a la policía. Eso sólo funcionaba en las ciudades, pues en el campo los esclavos eran punidos por el feitor o directamente por su dueño, generando en las más extremadas formas de violencia contra los esclavos o quien cayese en sus manos.

Creada la Intendencia, la Guarda Real de Polícia, réplica de la fuerza policial existente en Portugal, tenía un turno de trabajo integral, militar, con amplia autoridad para mantener el orden y perseguir criminales.

Subordinada a la Intendencia, la Guarda Real era mal vista por sus excesos y brutalidades, pero también elogiada por el "éxito" (léase violencia) en el trato dado a los negros y esclavos y en el mantenimiento del orden en la ciudad. Aquellos que la aprobaban también contribuían a su subsistencia, sin embargo la autoridad venía del

\footnotetext{
83 (HOLLOWAY, 1997: 115).

84 "Seu dono tinha de comparecer ao calabouço munido de autorização do intendente de polícia na qual deveriam constar 'o nome do delinquente e o número de chibatadas que deverá receber'. O carrasco encarregado de executar o castigo recebia una pataca por cem chibatadas aplicadas." (GOMES, 2007: 234).
} 


\section{Dimensiones histórico-sociológicas de la tortura en comisarías de Brasil: el caso Pernambuco}

Monarca, los recursos venían de tasas y subvenciones de los comerciantes locales y propietarios de tierras ${ }^{85}$.

Los dueños de esclavos también apreciaban que la Guarda Real sustituyera a los capitães-do-mato que eran los particulares responsables por la captura de esclavos fugitivos, representando un ahorro para los dueños de esclavos, así como un mayor control en las manos del Estado. Lo que se puede extraer de los estudios de Holloway (1997) es que la Guarda Real pasaba la mayor parte de su tiempo reprimiendo a los esclavos y buscando a los fugitivos ${ }^{86}$.

La regla para los policías de la Guarda Real era la brutalidad, principalmente, cuando estaban comandados por el mayor Miguel Nunes Vidigal, que, junto con su equipo, se quedaban escondidos en las esquinas y de repente aparecían en las rodas de capoeira o confraternizaciones de los esclavos y castigaban a todos los presentes ${ }^{87}$. La tortura era también el principal, sino único, método de investigación ${ }^{88}$ incluso antes de que la investigación se tornarse una rutina para las policías $^{89}$.

85 "A reciprocidade entre a fonte da autoridade do Estado e a elite econômica é um exemplo específico das relações mais gerais que explicam grande parte da evolução conservadora rumo à independência política do Brasil e o concomitante desenvolvimento das instituições do Estado." (HOLLOWAY, 1997: 48).

86 "A polícia também prendia ladrões e apartava brigas, mas seu forte era capturar escravos fugitivos. Impedir que grupos de escravos e negros livres se reunissem nas ruas ou agissem de maneira que a patrulha policial considerasse suspeita, desordeira ou desrespeitosa, e apreender quaisquer instrumentos que pudessem ser usados como armas por essa mesma categoria de pessoas". (HOLLOWAY, 1997: 54).

87 "Sem se importar com qualquer procedimento legal, mandava que seus soldados prendessem e espancassem qualquer participante desse tipo de atividade - fosse um delinqüente ou apenas um cidadão comum que estivesse se divertindo”. (GOMES, 2007: 234).

88 Según relato del inglés Jonh Luccock, que acudió a la Intendencia Geral de Polícia y relató un caso de hurto, sugiriendo el nombre de un mulato que trabajaba para él como posible sospechoso. De inmediato su empleado fue encarcelado y torturado, pero nada confesó. Pasada una semana sin noticias, Luccock volvió a la comisaría y supo que una vez más ellos lo habían torturado y esa vez el empleado había confesado "tácitamente". Pero como Luccock escuchó del propio intendente Viana que no había recuperado nada y éste no mencionó nada más sobre la situación de su empleado, él 


\section{Dimensiones histórico-sociológicas de la tortura en comisarías de Brasil: el caso Pernambuco}

Con el regreso de D. Juan I de Portugal a la metrópoli y el comienzo de la Regencia brasileña, su hijo el Príncipe Regente D. Pedro, debido a sus ideas liberales y a la fuerte influencia europea, trató de dictar algunas normas y reglamentos de las prácticas y los procedimientos de aplicación de la Ley, el establecimiento de garantías a los investigados o procesados y la introducción de preceptos liberales en la Constitución portuguesa.

Estas iniciativas entraron en vigor con el nuevo superintendente de la policía, John Inácio da Cunha, que ordenó que los prisioneros esclavos fuesen liberados sin castigo, a menos que hubiese condenas formales. Eso disgustó a sus subordinados que pensaron que sin los castigos ellos iban perder el control sobre los negros y provocó también la reacción de la Comisión de Seguridad en la Capital que buscó apoyo en el ministro de la Guerra para tratar de revertir la prohibición de los latigazos para quien fuera detenido, independientemente de la causa de la prisión. "El látigo, indicaba la comisión, era el único castigo capaz de intimidar e inspirar temor en aquellos que cometen semejantes ataques y homicidios" ${ }^{\prime 90}$.

Como se puede ver hay una gran distancia entre las intenciones liberales y la situación socio-económica de Brasil. La prevalencia de razones económicas y sociales ejercían fuerte presión para mantener la violencia contra los negros, esclavos o ya liberados.

entendió que había perdido no sólo los objetos hurtados, sino también el empleado que, probablemente, murió torturado por no saber nada sobre el destino de los objetos hurtados. (HOLLOWAY, 1997: 47).

89 "Uma conclusão que se pode tirar dos registros de 1810-21 é que o intendente, sua equipe e a Guarda Real que patrulhava as ruas em seu nome gastavam a maior parte de seu tempo tentando manter na linha os escravos. A polícia também prendia ladrões e apartava brigas, mas seu forte era capturar escravos fugitivos. Impedir que grupos de escravos e negros livres se reunissem nas ruas ou agissem de maneira que a patrulha policial considerasse suspeita, desordeira ou desrespeitosa, e apreender quaisquer instrumentos que pudessem ser usados como armas por essa mesma categoria de pessoas”. (HOLLOWAY, 1997: 54).

90 (HOLLOWAY, 1997: 56). 


\section{Dimensiones histórico-sociológicas de la tortura en comisarías de Brasil: el caso Pernambuco}

En 1824 la tortura fue abolida oficialmente ${ }^{91}$ a través de la Constituição do Império en su art. 179, inc. XIX, que prohibía los azotes, tortura y todas las demás penas crueles.

Cuando tomó posesión de su cargo en 1825, el tercer superintendente de la policía, Francisco Alberto Teixeira de Aragón, fue conocido por el endurecimiento de la política del mantenimiento del orden. Aragón estableció varias normas de la policía: impuso el toque de queda, la recompensa por la captura de los delincuentes, tratando de reducir las prácticas delictivas que habían aumentado significativamente en los años precedentes.

Entre 1500 y 1831 antes de que hubiera instituciones profesionales encargadas de hacer cumplir la ley, sólo existían las fuerzas militares y milicias que actuaban patrullando la ciudad con el único objetivo de "mantener el orden"92.

El mantenimiento de una pequeña élite ejerciendo tanto poder sobre una masa a punto de estallar refuerza el funcionamiento de un aparato represivo también explosivo.

Las fuerzas policiales que no eran suficientemente eficaces, estaban mal pagadas (o no pagadas), mal preparadas y, sobre todo, mal controladas. Sólo podían ser respetadas cuando representaban una amenaza concreta. En ese sentido, la policía creía que el temor que fuera capaz de inspirar haría tanto menor el trabajo para mantener el "orden público". La violencia fue el principal, cuando no el único,

\footnotetext{
91 "Nesse Estado de coisas, a tortura continuou sendo praticada, mesmo com a vedação constitucional, principalmente entre os escravos, cujos senhores eram detentores do direito de vida e de morte. Aliás, conforme salientado por C2 Coimbra, a tortura contra os escravos somente se encerrou com a extinção jurídica da escravidão, em 1888." (BURIHAN, 2008: 61-62).

92 Se entiende por mantenimiento del orden la retirada de los negros, desocupados y mendigos de las calles, sobre todo después de las 22:00h, la represión de rebeliones armadas, de las peleas entre vecinos, del combate a la ocupación urbana irregular, la embriaguez en las calles -especialmente la de los negros y marineros, los pequeños robos y la huida de esclavos.
} 


\section{Dimensiones histórico-sociológicas de la tortura en comisarías de Brasil: el caso Pernambuco}

método para garantizar el miedo y, en consecuencia, el "respeto" por las fuerzas de seguridad.

El Estado que también se preocupaba por la inestabilidad social y las posibles revueltas y disturbios violentos causados por la violencia excesiva de los propietarios de esclavos, poco a poco fue tomando para sí el control punitivo. Los propietarios de esclavos empezaron a pagar tasas de acuerdo a la cantidad de azotes administrados a los esclavos y los castigos dejaron de ser ejecutados en plaza pública. No era una medida humanitaria, sino de control social.

A los numerosos disturbios señalados anteriormente, se sumó, con la creciente urbanización, la resistencia de los esclavos, la llegada de extranjeros pobres y rebeldes y la posibilidad de revueltas armadas por cualquiera de las milicias o incluso los encargados de mantener el orden, que, bajo pésimas condiciones de trabajo, algunas veces eran los primeros en romperlo.

\subsubsection{Creación de los modelos actuales de policía}

En 1832 fue creado el Cuerpo de la Guarda Municipal Permanente con la idea de sustituir a la Guarda Real de Polícia por un cuerpo de voluntarios de la policía, militares, personas pagadas, profesionales, con el fin de dar seguridad a las personas y sus bienes. Hasta entonces, el patrullaje de las calles era algo no deseado por la Guarda Nacional, ni por los voluntarios.

Es interesante señalar que los castigos corporales eran empleados no solamente contra las personas detenidas, sino también contra los militares que 


\section{Dimensiones histórico-sociológicas de la tortura en comisarías de Brasil: el caso Pernambuco}

practicaban infracciones. Con la creación del nuevo cuerpo de policía permanente, fue eliminado el uso de castigos corporales contra los propios policías. Mientras tanto, la costumbre continuaba en el Ejército y en la Marina (en la Marina se utilizó hasta $\left.1910^{93}\right)$.

Según Vellasco, casi sólo había presencia policial, hasta mediados del siglo XIX, en las capitales de las principales provincias y en las otras pocas provincias en que había policía ésta era precaria, con número de policías insuficiente, de efectivos mal remunerados. Es más, apenas podían hacer frente a los borrachos, alborotadores, vagabundos y pequeños ladrones, siendo muy poco probable que haya ejercido el papel de órgano responsable del "control social", como arguyeron frecuentemente los historiadores de la época ${ }^{94}$.

La violencia se produjo bajo las dos formas siguientes: de la policía contra la sociedad y de la sociedad contra la policía. A veces por ser considerada esta última como el brazo armado del grupo que había sido depuesto, a veces como una insurgencia contra cualquier forma de control social, pero principalmente, por el repudio de sus actos violentos ${ }^{95}$. La "nueva" Policía Militar también era víctima de

93 En 1910, los marineros sublevados por la aplicación de violencia física como forma de disciplina crean el movimiento que fue denominado "Revolta da Chibata" (Chibata" es un aparato usado para castigar los caballos en un carruaje [látigo] y que fue muy utilizado para castigar a los negros). Liderados por Joao Cândido, asaltan a cinco buques de la Marina y amenazan bombardear el Río de Janeiro si los castigos no cesaban. El Congreso Nacional acepta la reivindicación y pone fin a la revuelta.

94 (VELLASCO, 2007).

95 "Como substituta da brutal e odiada Guarda Real de Polícia e como principal instrumento de força usado pelo novo Estado que lutava para controlar a ordem social, baseada en última instância na coerção, a Polícia Militar desfrutava de una posição pouco invejada. Já naqueles primeiros anos, tudo indicava que o cumprimento da função a ela atribuída no sistema não haveria de granjear-lhe muitos amigos. A hostilidade entre os membros da corporação e a sociedade, que por delegação eles deviam manter sob controle, manifestou-se desde cedo e persistiu. una das formas de hostilidade era física - as constantes agressões que os soldados da Polícia Militar cometiam contra as pessoas nas ruas, tanto antes como depois da prisão”. (HOLLOWAY, 1997: 135). 


\section{Dimensiones histórico-sociológicas de la tortura en comisarías de Brasil: el caso Pernambuco}

violencia por parte de los miembros más favorecidos de la sociedad ${ }^{96}$. Cabe señalar que a veces, esa élite, se quejaba también de la ausencia de violencia, cuando se trataba de los negros ${ }^{97}$.

No había reglas claras para el trabajo policial ${ }^{98}$. Las actividades eran transmitidas a través de la observación y pasaban del policía veterano al más joven. Lo que valía para las relaciones sociales también era aprovechado por la policía, o sea, para determinar quién puede ser encarcelado, quién puede ser castigado y así sucesivamente $^{99}$. Aunque haya habido una reducción significativa de los azotes cuando pasaron a ser ejecutados por el Estado, los castigos eran muy severos ${ }^{100}$.

A fines del siglo XIX, los negros no sólo sufrieron los abusos de la policía, sino que fueron, sin duda, los más afectados por ellos. Con la abolición de la esclavitud (1888), los negros pasaron a integrar un cuadro más amplio de

(HOLLOWAY, 1997: 136).

"Em 1873, houve una enxurrada de reclamações da parte dos senhores acusando o pessoal do Calabouço de tratar os escravos con brandura, de não raspar-lhes a cabeça na entrada conforme a prática usual e de valer-se de seus serviços para finalidades particulares durante o período de detenção". (HOLLOWAY, 1997: 214).

98 "Em 4 de julho de 1880, três guardas urbanos prenderam um negro por conduta desordeira na rua do Riachuelo e dirigiram-se con ele para a delegacia, surrando-o o tempo todo 'sem piedade'. Quando um transeunte censurou-lhes tal comportamento, o chefe da ronda afirmou que estavam apenas seguindo ordens".(HOLLOWAY, 1997: 221).

99 'No Rio, os critérios eram en grande parte determinados pela 'condição' dos objetos de atenção da polícia, incluindo-se aí identidade racial, maneira de falar e vestir, e comportamento do suspeito, bem como local e hora do dia. Mas a decisão de parar e revistar era arbitrária”.(HOLLOWAY, 1997: 139).

100 "De modo geral o açoitamento diminuiu, mas os casos extremos desmentem a noção de que as regras haviam mudado. Em agosto de 1844, João, escravo crioulo, foi mandado ao Calabouço para ser punido con 700 açoites, sentença imposta pelo júri por ter causado ferimentos graves a outra pessoa. Após receber o total de 500 açoites, 50 por vez - graças à reforma 'humanitária' do início da década de 1830 -, intercalados por períodos de recuperação, João morreu em 3 de abril de 1845 em decorrência das 'feridas e contusões na região glútea, complicadas por disenteria'”.(HOLLOWAY, 1997: 193). 


\section{Dimensiones histórico-sociológicas de la tortura en comisarías de Brasil: el caso Pernambuco}

perseguidos ${ }^{101}$ : esto es, negros, pobres y extranjeros sin una actividad regular ${ }^{102}$. Además, posteriormente, en la primera República entraría en escena un nuevo tipo: "las clases peligrosas" ${ }^{103}$ compuesto por los sindicalistas, miembros de movimientos obreros y anarquistas ${ }^{104}$.

A pesar de que hubo muchos cambios modernizadores acometidos con la proclamación de la República (1890), tales como una creciente profesionalización de la policía, que entonces pasó a trabajar a tiempo completo y con profesionales remunerados, no hubo muchos cambios con respecto al foco de actuación de la policía $^{105}$ : negros ${ }^{106}$, pobres e inmigrantes ${ }^{107}$. Pero sin duda, lo que más incomodaba

101 "Finalmente, há os "elementos" do jargão policial, cidadãos de terceira classe. São a grande população marginal das grandes cidades, trabalhadores urbanos e rurais sem carteira assinada, posseiros, empregadas domésticas, biscateiros, camelôs, menores abandonados, mendigos. São quase invariavelmente pardos ou negros, analfabetos, ou con educação fundamental incompleta. Esses “elementos" são parte da comunidade política nacional apenas nominalmente. Na prática, ignoram seus direitos civis ou os têm sistematicamente desrespeitados por outros cidadãos, pelo governo, pela polícia".(CARVALHO, 2001: 87).

102 "Nas esferas econômicas, legal e judicial não houve rupturas bruscas com o passado. No início do século, a polícia funcionava como extensão, sancionada pelo Estado, do domínio da classe proprietária sobre as pessoas que lhe pertenciam. A polícia cresceu acostumada a tratar os escravos $e$ as classes inferiores livres de maneira semelhante, e, com a diminuição gradativa do número de escravos na população após meados do século, as atitudes e práticas dos sistemas de repressão foram aos pouco sendo transferidas para as classes inferiores não-escravas - $e$ perduraram”.(HOLLOWAY, 1997: 214-215).

103 Vellasco llama la atención para el equívoco de utilizar la expresión "clases peligrosas" en Brasil, pues cree que el contexto en el Imperio era bien distinto del escenario europeo donde la expresión había sido acuñada. (VELLASCO, 2007).

104 "Paralelamente às correntes pacifista, havia entre os anarquistas os defensores da ação direta, em outras palavras, do emprego da violência contra as classes dominantes, tal qual ficou registrado, no início do século XX, em panfletos anexos aos processos contra militantes cariocas, onde consta a defesa do assassinato sistemático de 'burgueses' através do envenenamento do leite com biclorato de mercúrio”.(DEL PRIORE \& VENÂNCIO, 2001: 288).

105 "No início dos século, no primeiro período republicano quando houve um surto notável de criminalidade, predominaram os atentados à ordem pública como razão para prender pessoas. Boris Fausto comparou o número de detidos por esse motivo com o número de pessoas que foram processadas efetivamente em São Paulo. Descobriu que, entre 1912 e 1916, as prisões por vadiagem, 


\section{Dimensiones histórico-sociológicas de la tortura en comisarías de Brasil: el caso Pernambuco}

a la élite brasileña en aquella época era la cantidad de negros, pardos y pobres (incluso inmigrantes ${ }^{108}$ ) que vivían en favelas cada vez más grandes en las principales Capitales ${ }^{109}$.

La molestia estaba causada por al menos dos razones: la inseguridad generada por robos y otras transgresiones a los costumbres, tales como batuques, rodas de capoeira ${ }^{110}$, y también el alejamiento cada vez más grande del modelo

embriaguez e desordem, que apenas desobedeciam a regras de comportamento público no município, correspondiam a 86\% de todas as prisões". (ZALUAR, 1998: 268-269).

106 "A opção pelo trabalhador imigrante nas áreas regionais mais dinâmicas da economia e as escassas oportunidades abertas ao ex-escravo em outras áreas resultaram em uma profunda desigualdade social da população negra. Fruto em parte do preconceito, essa desigualdade acabou por reforçar o próprio preconceito contra o negro. Sobretudo nas regiões de forte imigração, ele foi considerado um ser inferior, útil quando subserviente ou perigoso por natureza, ao ser visto como vadio e propenso ao crime”. (FAUSTO, 2002: 124-125).

107 "A partir do início do século XX, principalmente no eixo Rio de Janeiro e São Paulo, os conflitos entre polícia e operários entrariam em ebulição. Embora não tivessem a força dos movimentos europeus, foi suficiente para preocupar os dirigentes brasileiros que responderiam con a coerção policial e "a promulgação, en 5 de janeiro de 1908, da lei Adolfo Gordo. Por esta lei o estrangeiro que, por qualquer motivo, comprometesse a segurança nacional ou a tranqüilidade pública, poderia ser expulso”. (FRAGOSO, 1990: 195).

$108 \quad$ [...] os homens recém-vindos do Japão, não hesitaram em se desvencilhar de todas as suas vestes, e en pêlo, de um salto, mergulharam no rio. O assombro da platéia brasileira foi imensurável. Nem os nativos tomariam tal atitude! Que bárbaros eram aqueles japoneses! Consternados, correram a avisar a polícia local. A autoridade, mais sensata, no lugar da esperada providência enérgica simplesmente declarou tratar-se de una diferença de hábitos [...]. (ZULEICA, 1998: 261).

$109 \quad$ "O chefe de polícia da capital deu ordens para que toda e qualquer pessoa abordada no centro da cidade que não pudesse comprovar emprego e residência fixos, fosse detida. Como a tripla reforma criara um imenso déficit habitacional e como a maioria da população vivia de expedientes temporários, num mercado de emprego instável, esse decreto envolvia praticamente toda a população pobre. Os detidos eram levados para a ilha das Cobras, onde eram despidos e violentamente espancados, para então ser espremidos nos porões de vapores que partiam incontinenti para a Amazônia.” (WISSENBACH, 1998: 26).

110 "A capoeira - reprimida pela polícia do final do século passado e incluída como crime no Código Penal de 1890 - é oficializada como modalidade esportiva nacional em 1937. Também o samba passou da repressão à exaltação, de 'dança de preto' a 'canção brasileira para exportação'. Definido na época como uma dança que fundia elementos diversos, nos anos 30 o samba sai da marginalidade e ganha as ruas, enquanto escolas de samba e desfiles passam a ser oficialmente subvencionados a partir de 1935." (SCHWARCZ, 1998: 196). 


\section{Dimensiones histórico-sociológicas de la tortura en comisarías de Brasil: el caso Pernambuco}

europeo, en especial parisiense ${ }^{111}$, tan deseado por la élite brasileña que era obligado a convivir con tanta miseria, condiciones sanitarias precarias y un gran atraso social $^{112}$.

\subsubsection{Los períodos dictatoriales}

Desde la implantación de la República de Brasil, hubo una creciente preocupación por su equiparación jurídica y social con otras naciones. Eso significó una mejora en la legislación y en el trato con los criminales y la población

111 "As pessoas que não pudessem se trajar decentemente, o que implicava, para os homens, calçados, meias, calças, camisa, colarinho, casaco e chapéu, tinham seu acesso proibido ao centro da cidade. Mais que isso, nas imediações, as tradicionais festas e hábitos populares, congregando gentes dos arrabaldes, foram reprimidos e mesmo o Carnaval tolerado não seria mais o do entrudo, dos blocos, das máscaras e dos sambas populares, mas os dos corsos de carros aA1s, das batalhas de flores e dos pierrôs e colombinas bem-comportados, típicos do Carnaval de Veneza, tal como era imitado em Paris”. (SEVOCÊENKO, 1998: 26-27).

112 "Em São Paulo, durante as duas primeiras décadas republicanas, as prisões por desordens aumentaram em 40\%, enquanto as por embriaguez cresceram quase 400\%. Paralelamente a isso, a exclusão dos egressos do cativeiro no mercado de trabalho livre acentuava a prática de furtos. em cidades como Campinas do início do século XX, negros e pardos representavam apenas $20 \%$ da população total, mas respondiam por cerca de metade da população carcerária. Os dados cariocas mostram, por sua vez, que imigrantes europeus nem sempre desfrutaram melhores condições. Em 1903, cerca de 114 portugueses, residentes na Capital Federal, foram expulsos do Brasil, sob a acusação de vadiagem e roubo, e, entre 1915-1918, responderam por 32\% dos processos criminais, apesar de constituírem apenas $15 \%$ da população masculina adulta do Rio de Janeiro”.(DEL PRIORE \& VENÂNCIO, 2001: 292). 


\section{Dimensiones histórico-sociológicas de la tortura en comisarías de Brasil: el caso Pernambuco}

socialmente más vulnerable. En general, más bien esto fue fruto de un deseo de parecerse a otras naciones más desarrolladas que de hacer justicia social. Sin embargo, hubo un camino inverso cuando hablamos de la adquisición de derechos. Al contrario de lo ocurrido en el continente europeo, primero fueron reconocidos los derechos sociales y después los derechos políticos, para más tarde dar paso a los derechos civiles.

Si verificamos que a lo largo de toda la construcción de la nación brasileña hubo tortura y violencia por parte del Estado, no podríamos esperar que en un período dictatorial, donde los derechos civiles y garantías fundamentales son suspendidos, fuera diferente. Las dictaduras representaran un absurdo aumento de la violencia como condición para su propia existencia, pues donde hay respeto a los derechos individuales no hay espacio para dictaduras.

Las dictaduras se valieron de una nueva unidad policial que surgió a principios del siglo XX: esto es, la policía política ${ }^{113}$. Se creó inicialmente para reprimir los movimientos anarquistas ${ }^{114}$ y sindicales constituidos principalmente por inmigrantes italianos, pero se amplió su alcance a cualquier movimiento político que amenazara el "orden social” establecido.

Justamente ese tipo de unidad policial será uno de los grandes responsables de la extensión del uso de la tortura contra miembros de la sociedad que hasta entonces tenían poquísimas probabilidades de sufrir torturas. Esto primero ocurrió en

\footnotetext{
113 "Ao mesmo tempo que a repressão ideológica alarga seus horizontes através da oficialização, avulta o papel da Polícia Secreta, chefiada por Felinto Muller. Tal como nos regimes totalitários europeus, a Polícia Secreta se especializa en práticas violentas reprimindo, através da tortura e do assassinato, os indivíduos considerados nocivos à ordem pública." (KOSHIBA \& PEREIRA, 1978: 262).

114 Capelato al se referir a la represión policial durante la dictadura de Vargas: "Houve repressão forte - prisões, tortura, exílios, censura - , que atingiu tanto os considerados subversivos (comunistas, socialistas, anarquistas) como os opositores liberais". (CAPELATO, 2003: 131).
} 


\section{Dimensiones histórico-sociológicas de la tortura en comisarías de Brasil: el caso Pernambuco}

la dictadura de $\operatorname{Vargas}^{115}$ y después llegó a su ápice en la dictadura militar, desde 1964 hasta 1984.

En esos períodos de excepción, la policía, y en especial la policía política ${ }^{116}$, ejerce una represión extremadamente violenta en el curso de la cual la tortura y los asesinatos representan una práctica cotidiana ${ }^{117}$.

Cabe resaltar que en los periodos dictatoriales la violencia es más "democrática", pues cualquiera puede convertirse en víctima, con independencia de la clase social, color de la piel o status político, mientras en los períodos autodenominados democráticos sólo están sujetos a la tortura los pobres, grupos minoritarios y con dificultad para defenderse. Es como si en los períodos de excepción dictatorial la policía recibiese una patente de corso para ejercer sobre la totalidad de la población y sin disimulo lo que siempre hizo con los pobres y demás marginados de la sociedad.

La violencia fue especialmente fuerte en el periodo de la Dictadura Militar, que va de 1964 a 1984, período marcado por la lucha contra el avance del comunismo, en el que los excesos fueron los más significativos no sólo por el incremento de la violencia estatal ${ }^{118}$, sino también porque los derechos ya

115 "Desde os anos 20 - com o incremento do movimento anarquista - esta prática vinha recrudescendo: muitos militantes políticos foram presos e torturados. Da mesma forma, durante a ditadura de Getúlio Vargas, conhecida como Estado Novo (1937-1945), muitos opositores sofreram suplícios nas polícias políticas de diferentes Estados."(COIMBRA, 2001:13).

116 "Criada, oficialmente, em 23 de dezembro de 1935, o Dops é chamada de delegacia e assim foi até meados de 57, início de 60, quando vai haver uma grande reestruturação e ela passa a atender com outras prerrogativas. Então, inicialmente, a Delegacia de Ordem Política e Social era uma seção de Ordem Política e Social e teve seu início em 1931 após a Revolução de 30, numa grande reforma que se deu na administração pública.”(GAMA, 2007: 151).

117 "Veteranos repórteres policiais denunciaram que as torturas eram do tipo usado para arrancar confissões de suspeitos de crimes comuns. (SKIDMORE, 1988: 57).

118 La "siniestra institución educativa que se concentró en la acción anti-insurreccional y anticomunista y que sentó las bases de la denominada Doctrina de la Seguridad Nacional (DSN) 


\section{Dimensiones histórico-sociológicas de la tortura en comisarías de Brasil: el caso Pernambuco}

incorporados en la sociedad estaban muy avanzados cuando hubo un recrudecimiento de esta práctica, al contrario de otras épocas en las que la violencia era mejor aceptada por el colectivo social.

Pasado el período dictatorial de 1964, Brasil cambia su Constitución Federal y pasa a tener una Constitución bastante garantista de los derechos individuales y fundamentales. Junto con las nuevas leyes, entran en escena nuevas posibilidades de control del Estado ejercido por la fiscalía, las ONG, la prensa etc.

No pretendemos aportar relatos históricos relativos a los períodos de las dictaduras por dos razones: la violencia policial de ese periodo ha sido exhaustivamente investigada y planteada; se trata de una violencia en un período de excepción, en la que los derechos habían sido suprimidos, había otro contexto histórico-político, había participación de otros actores y la violencia policial era mucho más fuerte. Como buscamos justamente los patrones generales de violencia y ya nos extendemos demasiado en las referencias históricas, preferimos dejar a un lado los períodos de excepción.

adiestró a los mayores torturadores de América Latina. (...) La 'Escuela' puede considerarse de este modo uno de los embriones de los actuales escándalos de tortura en Abu Ghraib y Guantánamo. (...) La preocupación se amplifica si tenemos en cuenta que actualmente la Escuela de las Américas se denomina Instituto de Cooperación para la Seguridad Hemisférica (Western Hemisphere Institute for Security Cooperation, WHINSEC) y es sólo una pequeña parte de una amplísima y compleja red de programas Estadounidenses de formación de fuerzas militares y policiales extranjeras. Existen en la actualidad aproximadamente 275 Academias e instalaciones militares de este tipo que ofrecen más de 4.000 cursos, lo que supone que EEUU proporciona cada año formación sobre técnicas de combate y doctrina policial y militar Estadounidense para un mínimo de 100.000 policías y militares extranjeros procedentes de más de 150 países.” (GASCÓN, 2008: 77-78). 


\section{Dimensiones histórico-sociológicas de la tortura en comisarías de Brasil: el caso Pernambuco}

\subsubsection{Conclusión}

Frente a lo que muchos afirman, que la tortura policial es una práctica heredada de la Dictadura de $1964^{119}$ y fruto de la misma, queda claro que desde el descubrimiento de Brasil hasta hoy día siempre hubo tortura con independencia del período histórico y del régimen político.

Con el ocaso de los regímenes de excepción, la policía empieza, poco a poco, en la medida que el Estado de Derecho se va regenerando, a disminuir sus prácticas abusivas y también a restringir el grupo de afectados por tales abusos. Con todo, incluso con nuevas leyes y nuevos agentes, la policía continúa torturando y, en muchas comisarías de Brasil, la tortura es considerada como un mero procedimiento de investigación ${ }^{120}$ que es aplicado, a menudo, a los "no-ciudadanos".

Aunque se utiliza cada vez menos, pues los mecanismos para investigar delitos son más eficientes que otrora, e incluso los mecanismos de control son más avanzados, aún se utiliza con una intensidad alarmante ${ }^{121}$. Es así hasta el punto de

\footnotetext{
119 "Dezesseis anos após ter a ditadura militar cedido lugar à democracia presidencial, o uso da tortura e dos maus-tratos continua a ser feito no mesmo grau e permanece geralmente impune. No Brasil de hoje, tortura e maus-tratos deixaram de ser armas de repressão política e se transformaram nas ferramentas essenciais da rotina policial diária”. (AMNISTIA INTERNACIONAL, 2001: 05)-

${ }_{120}$ "Assim como disse à Justiça várias vezes, Renato, o primeiro a ser preso naquela manhã em que acharam o corpo de Vanessa, afirma ter sido levado para um matagal na estrada do Cabuçu e ter sido torturado por PMs para confessar o crime. Além de espancamentos, Renato diz que os PMs também jogaram gás pimenta en seus olhos.(...). Os três relataram à Justiça que também foram torturados diversas vezes, inclusive com aplicação de choques com uma máquina de manivela e com a colocação de sacos plásticos em suas cabeças para sufocamento, dentro do $1^{\circ} \mathrm{DP}$. O delegado que fez a prisão do trio e outros policiais civis também são investigados pela tortura. (FOLHA, 2008: C3)."

121 "Mesmo a polícia civil, que não tem treinamento militarizado, se vem mostrando incapaz de agir dentro das normas de uma sociedade democrática. Continuam a surgir denuncias de prática de
} 


\section{Dimensiones histórico-sociológicas de la tortura en comisarías de Brasil: el caso Pernambuco}

que una ONG escribió un "manual" de cómo protegerse de la violencia policial: "Cartilha de Defesa dos Direitos Humanos contra a Violência Policial. Violência Policial, Não: Porque Todos Têm Direito a Dignidade”. (CEAP, 2002) ${ }^{122}$.

Los discursos y la leyes cambiaron mucho ${ }^{123}$, pero en una cosa la historia no cambió, los marginados o excluidos son las víctimas preferenciales y, casi siempre, únicas de la tortura. Fueron los negros e indígenas inicialmente, después los negros $^{124}$, los pobres y los miserables ${ }^{125}$. En esa práctica, la policía cuenta con la complicidad y condescendencia de una cantidad representativa de la población y de gran parte de las autoridades ${ }^{126}$. O como dijo Paixão (1988), en un escenario de

tortura de suspeitos dentro das delegacias, apesar das promessas de mudança feitas pelos governos estaduais." (CARVALHO, 2001: 213).

122 Véase: "relatório sobre a tortura no Brasil produzido pelo relator especial da Comissão de Direitos Humanos da ONU, 2001. (www.global.org.br/relatoriotortura.htm).

$123 \quad$ “.... o país tem uma legislação penal sintonizada com o que há de melhor no pensamento jurídico liberal e humanitário, mas que simplesmente não funciona; falta-lhe a sintonia fundamental com a realidade sócio-econômica da nação". (COELHO, 1998: 164).

124 "Testamentos examinados por Kátia Mattoso mostram que $78 \%$ dos libertos da Bahia possuíam escravos. Na Bahia, em Minas Gerais e em outras províncias, dava-se até mesmo o fenômeno extraordinário de escravos possuírem escravos. De acordo com o depoimento de um escravo brasileiro que fugiu para os Estados Unidos, no Brasil 'as pessoas de cor, tão logo tivessem algum poder, escravizariam seus companheiros, da mesma forma que o homem branco'.

Esses dados são perturbadores. Significam que os valores da escravidão eram aceitos por quase toda a sociedade. Mesmo os escravos, embora lutassem pela própria liberdade, embora repudiassem sua escravidão, uma vez libertos admitiam escravizar os outros. Que os senhores achassem normal ou necessária a escravidão, pode entender-se. Que libertos o fizessem, é matéria para reflexão. Tudo indica que os valores da liberdade individual, base dos direitos civis, tao caros à modernidade européia e aos fundadores da América do Norte, não tinham grande peso no Brasil.”(CARVALHO, 2001: 48-49).

$125 \quad$ “(...) se atentarmos para o fato de que essas ações dirigem-se sistematicamente contra os segmentos colocados nas posições mais baixas da estratificação social, não há como se negar o caráter classista das mesmas." (OLIVEIRA, 1985: 86).

126 "A maioria dos entrevistados disse acreditar que a justiça criminal discrimina, conforme cor e condição econômica. Se uma pessoa negra e uma branca praticarem o mesmo crime, a justiça vai tratar a negra mais rigorosamente, segundo 66,4\% dos entrevistados. Esta crença ̀̀ maior entre os negros (70,9\%), mas não muito menor ente os brancos (64,5\%). Se uma pessoa rica e uma pobre 


\section{Dimensiones histórico-sociológicas de la tortura en comisarías de Brasil: el caso Pernambuco}

imposición del orden público en una sociedad democrática, pero socialmente injusta, se irroga la policía la misión de seleccionar qué individuos tienen derecho a sus derechos constitucionales.

praticarem o mesmo crime, a justiça vai tratar a pobre mais rigorasamente, segundo 95,8\% dos entrevistados. As pessoas de nível econômico baixo entrevistadas desacreditam um pouco menos na justiça (92,5\% deles emitiram esta mesma resposta). Estes dados sugerem que há um consenso entre a população de que não há isonomia nas ações da justiça, variando conforme cor ou condição social de cada infrator. $O$ que indica que há um paradoxo para as instituições democráticas brasileiras e para o Estado de Direito: a lei é igual para todos, mas não parece ser aplicada igualmente para todos." (FERREIRA, 2002: 43). 


\section{Dimensiones histórico-sociológicas de la tortura en comisarías de Brasil: el caso Pernambuco}

\section{ASPECTOS ÉTICOS LEGALES DE LA TORTURA}

\subsection{Los resultados de la tortura}

A lo largo de la Historia la tortura fue usada como ofrenda a los dioses; como método de investigación para descubrir la autoría de algún acto contrario a las leyes y costumbres de la época; como método punitivo ${ }^{127}$ del poder instituido ${ }^{128}$; o, como venganza (ojo por ojo, diente por diente); incluso se llegó a usar como método de intimidación para evitar la práctica de crímenes y es por ello que muchos suplicios eran públicos.

La gran distinción del uso de la tortura hasta la Edad Moderna y la actualidad es que hoy es considerada moral y jurídicamente inaceptable. Con todo, en lo tocante a la motivación para practicarla, ésta sigue siendo la misma desde hace diez siglos: es decir, su presunta "eficiencia", pues bien sea como una ofrenda a los dioses o para descubrir la autoría de un delito, sólo practican la tortura quienes creen que es eficiente para tal fin. Por ello, no es posible hablar sobre las razones de la

\footnotetext{
127 "En Grecia, los propietarios romanos de esclavos tenían el derecho absoluto de castigar y torturar a sus esclavos, cuando sospechaban que eran culpables de delitos contra ellos dentro de sus propiedades. Este derecho no fue abolido en la ley romana hasta el 240 d. de C., por un rescripto del emperador Gordiano (Código 9.41.6)”. (PETERS, 1987: 35).

128 "O Papa Inocencio I (401-417) escreve em sua Epístola VI: 'Pediram-nos a opinião sobre aqueles que, após haverem recebido o batismo, tiveram cargos públicos e exerceram a tortura, ou aplicaram sentenças capitais. A este respeito nada nos foi transmitido'. Iniciava-se, pois, o consentimento implícito às normas processuais romanas, apesar da suposta cristianização do processo.” (SZNICK, 1998: 27).
} 


\section{Dimensiones histórico-sociológicas de la tortura en comisarías de Brasil: el caso Pernambuco}

persistencia del uso de la tortura sin hablar sobre su eficiencia potencial ${ }^{129}$. Así que, antes de que discutamos sobre si es moralmente aceptable o no, tenemos que aclarar este punto. Pues, si no fuera eficiente, sería sólo cuestión de demostrarlo y difundir tal información. No obstante, si es de alguna manera "eficiente", costará más implantar otros métodos de investigación tan accesibles como éste y con el mismo grado de operatividad, o en su caso, hemos de esforzarnos para encontrar razones morales suficientes que imposibiliten su uso, aunque sea "eficiente".

A pesar de que este planteamiento parezca obvio, no es algo muy sencillo, pues se trata de una cuestión cargada de emoción y prejuicio, en la que el simple enunciado "eficiencia de la tortura" ya genera reacciones violentas e indignadas, incluso en los medios académicos ${ }^{130}$. Esto es así sobre todo en Brasil, donde la

\footnotetext{
129 "Sin embargo, a favor de la tortura creo que hay un factor no valorado debidamente por los filósofos ilustrados: su eficacia. Si nos preguntamos acerca de la justicia de la tortura, podremos calificarla de injusta, tan injusta como una ordalía; si analizamos su crueldad, podremos considerarla incluso más cruel y cruenta que muchas ordalías; pero como procedimiento para averiguar la verdad, aunque ciertamente falle en muchos casos y pese a que provocará con toda seguridad más confesiones que confesiones veraces, es innegable que resulta mucho más eficaz que cualquier rito mágico ordálico. Sobre todo teniendo en cuenta que su eficacia opera en un doble sentido: como medio para descubrir la verdad, y como instrumento para intimidar al torturado y a quienes se sienten potencialmente en su lugar. Si no fuera eficaz la tortura en su doble efecto inquisitivo e intimidatorio, no estaríamos aquí y ahora hablando de ella; si no fuese eficaz no habría sobrevivido durante siglos ni habría resurgido en el nuestro; si no fuese eficaz no sería, como ha sido y tal vez sigue en cierta medida siendo, procedimiento empleado en períodos de fortalecimiento del poder, y en función principalmente de los delitos que hayan podido o puedan poner en cuestión los mecanismos y resortes últimos de ese mismo poder". (TOMÁS Y VALIENTE, 2000: 209).

130 "Howard Becker (1967) afirma que estudar grupos rotulados como 'desviantes' pode levantar a suspeita de que os pesquisadores aceitam o ponto de vista 'ilegítimo' desse grupo colocando o pesquisador em posição de ser rotulado como 'enviesado' ou até mesmo como desviante". (HUGGINS et al, 2006: 78).
} 


\section{Dimensiones histórico-sociológicas de la tortura en comisarías de Brasil: el caso Pernambuco}

tortura practicada durante la Dictadura de 1964 alcanzó mayoritariamente a los académicos $^{131}$.

Cuando confrontamos los relatos de Verri ${ }^{132}$ o Beccaria ${ }^{133}$ sobre la baja eficiencia de la tortura, una vez que alguien débil puede confesar algo que no hizo para terminar con el martirio y, por el contrario, alguien fuerte puede resistir y pasar impune por una tortura, tenemos que reconocer el peso de tales argumentos y aceptarlos. Sin embargo, podríamos cuestionar si la no aceptación de la tortura sería solamente una obligación moral o una práctica útil. Cuando un policía tortura a

“'explica que, como o movimento estudantil 'era o mais ativo e articulado, era ali que se
recrutavam militantes'.
Assim, os estudantes viram alvo principal dos militares, em ações de operação bélica, mais
que policial. Segundo o projeto-livro Brasil Nunca Mais, 'num período em que a população de nível
superior no Brasil atingia 1,4\% da população, este pequeno contingente contribuía com $39 \%$ dos
casos de morte por razões políticas, $26 \%$ dos casos de tortura e $21 \%$ dos casos denunciados'.

Ou seja, proporcionalmente, a morte se abatia sobre os estudantes 28 vezes mais do que sobre outras categorias; a tortura, 18 vezes mais; e havia 15 vezes mais denúncias sobre estudantes atingidos do que sobre pessoas de outras categorias".(CAROS AMIGOS, 2007; 227).

132 "La mayor parte de los jueces se han habituado gradualmente a los espasmos de las torturas por un principio respetable, esto es, sacrificando el horror de los males de un hombre solo, tenido por delincuente, en vista del bien general de la sociedad entera. Aquellos que defienden la práctica criminal, lo hacen creyéndola necesaria para la seguridad pública y persuadidos de que, si se aboliese la severidad de la tortura, los delitos quedarían impunes y se privaría al juez de la vía para investigarlos. Yo no reprocho ningún defecto a quien razona así, pero creo que están en un error evidente, y en un error cuyas consecuencias son crueles. También los jueces que condenaban a la hoguera a las brujas y los hechiceros en el siglo pasado, creían purgar la tierra de los más fieros enemigos, y, sin embargo, no hacían sino inmolar víctimas al fanatismo y la locura." (VERRI, 1977: $3-4)$.

133 "Un hombre no puede ser llamado culpable antes de la sentencia del juez, ni la sociedad puede quitarle la protección pública sino cuando se haya decidido que violó los pactos con los que aquella protección le fue acordada. ¿Cuál es, pues, el derecho, sino el de la fuerza, que concede poder a un juez para aplicar una pena a un ciudadano mientras se duda si es culpable o inocente? No es cierto o incierto; si es cierto, no le corresponde otra pena que la establecida por las leyes, y los tormentos son inútiles en tal caso, como inútil es la confesión del reo, si es incierto, no se debe atormentar a un inocente, porque tal es según las leyes un hombre cuyos delitos no están probados." (BECCARIA, 1982: 95). 


\section{Dimensiones histórico-sociológicas de la tortura en comisarías de Brasil: el caso Pernambuco}

alguien para saber dónde están los objetos robados y los encuentra, o cuando tortura a un asesino y descubre dónde está un cadáver y cómo se produjo su muerte, también tenemos que admitir, contrariando el argumento anterior, su "eficiencia". Incluso cuando un inocente confiesa algo que no hizo no quiere decir que la tortura es, en principio, "ineficiente", pero sí que es falible.

Ante tales argumentos ¿podríamos decir que la tortura es "eficiente”? Creemos que no. Para que (al margen de la "indiscutible" objeción moral) consideremos la tortura "eficiente" deberíamos encontrar una relación entre la alta resolución de crímenes y el bajo riesgo de inculpar inocentes.

Y no es eso lo que encontramos cuando investigamos su utilización. La única manera de lograr la ecuación de la resolución asociada al bajo riesgo de inculpar inocentes, dependería de que, antes de torturar, los policías recogieron la mayor cantidad de pruebas posibles, disminuyendo así el riesgo de torturar a una persona inocente. Sin embargo, cuando se recoge una gran cantidad de indicios, también disminuye la "necesidad" de torturar. De esa manera la tortura será tanto más eficiente cuanto más innecesaria sea. Por lo contrario, si no se busca tales indicios la probabilidad de alcanzar inocentes será muy alta y por eso mismo ineficiente. Por lo tanto, un método que tiene por objetivo encontrar los verdaderos culpables, y hasta llegar a ellos tortura muchos inocentes no puede ser considerado eficiente.

La tortura de "culpables" de un delito "tendría cabida" como una mera forma de rellenar los espacios en blanco de las cuestiones no explicadas. Con todo, ¿eso sería justificable? Creemos que no, al menos por las siete razones que siguen:

Primero porque es ilegal. Y no sólo en la legislación penal, sino también, con mucho énfasis, en la Constitución Federal. Sólo con eso ya no habría más que decir, porque no es imaginable que una policía que tiene como atribución la resolución de crímenes sea la primera en cometerlos. 


\section{Dimensiones histórico-sociológicas de la tortura en comisarías de Brasil: el caso Pernambuco}

Segundo, por cuestiones morales. Nuestro sistema de justicia es falible y pueden darse casos de inocentes que fueran penalizados. Pero éste no se establece en pilares injustos. La idea de multiplicidad de recursos se ampara en la posición de que es mejor absolver a un culpable por falta de pruebas o de tiempo, que condenar a un inocente por falta de recursos o tiempo escaso para su defensa. Otro principio es el de la presunción de inocencia, por el que el sospechoso será considerado inocente hasta la condena final, cuando no sea posible otro recurso. Lo que ocurre con la tortura es exactamente lo contrario. Pues si hay certeza de la culpa no hay razón para torturar. Y si no hay tal certeza - respetando el principio de inocencia - jamás debería ser torturado.

La tercera razón es porque hace dos siglos que se abolió la tortura. Eso es un reflejo de los avances históricos y culturales alcanzados durante siglos, o de lo que podríamos denominar "proceso civilizador". Permitir la tortura es ser negligente con toda la evolución de los derechos humanos y avances de los principios éticos, jurídicos y políticos. Lo que hace la tortura inadmisible hoy es que parte de métodos abominados por nuestra cultura actual: la violencia para obtener informaciones. Y peor aún, no es sólo un método terrible, sino que se utiliza mal, y esto es aún más cruel, puesto que aplica la violencia a seres inocentes.

La cuarta razón es por racionalidad, pues cuando observamos que en muchos casos la tortura es practicada para la resolución de crímenes patrimoniales, vemos cuán absurda es su utilización: la pena establecida por la sociedad para los crímenes patrimoniales es menor que la pena que implica la tortura. Es como si la policía practicase un delito más grave para descubrir el autor de un delito menos grave.

La quinta razón es el respeto al sistema de justicia criminal puesto que todos los sistemas criminales de los países democráticos están basados en un proceso, que busca pruebas sobre la inocencia o culpabilidad de algún sospechoso, para después, 


\section{Dimensiones histórico-sociológicas de la tortura en comisarías de Brasil: el caso Pernambuco}

basándose en las pruebas adquiridas infligir un castigo. El uso de la tortura por la policía rompe ese sistema ya que castiga antes del proceso. Y además penaliza de una forma más cruel que la que podría tener si fuera probada su culpa.

La sexta razón es el peligro que representa la permisividad con determinadas prácticas delictivas de generar otros crímenes. Como es algo clandestino, la tortura obliga a sus practicantes a esconderse, crea una complicidad con la ilicitud que estimula la práctica de otras ilicitudes. Eso puede ser verificado en muchos relatos donde el torturador no sólo buscaba la información principal sino que también cometía violaciones, hurtos, extorsiones y homicidios. Para algunos, después de algún tiempo la búsqueda de la información principal se convertiría en sólo un pretexto para practicar los delitos arriba citados.

La séptima razón para erradicar la tortura es porque existen otros métodos distintos. Es más, las policías consideradas más eficientes son las que menos torturan. La explicación es que con el control ejercido sobre la práctica de la tortura, la policía fue obligada a perfeccionarse. Cuanto mayor es el control, mayor es la necesidad de buscar nuevos métodos que sean más eficientes ${ }^{134}$, acordes con el ordenamiento legal.

Lo que hace tan odiosa la tortura no es tan sólo la posibilidad de que un inocente sufra daños. Eso también ocurre en el sistema de justicia criminal y no genera un movimiento para extinguirlo. Bastaría preguntarse por qué mantener un método que es ilegal e inmoral cuando hay otras posibilidades disponibles para

\footnotetext{
$134 \quad$ "Sobre a Inglaterra, escreve Jacó Federico Bielfeld, Barão de Bielfeld (1716-1770), natural de Hamburgo: 'Desde que a experiência fez ver que na Inglaterra e na Prússia os delitos se descobrem e se punem, que a justiça se exerce e a sociedade não sofre, é quase bárbaro não se abolir o emprego da tortura. Quem quer que tenha entranhas e haja visto uma vez uma violência tal à naturalidade humana, não os pode, creio eu, ser de parecer diverso.' (Inst. Políticas, Haia, 1760)". (SZNICK, 1998: 35-36).
} 


\section{Dimensiones histórico-sociológicas de la tortura en comisarías de Brasil: el caso Pernambuco}

combatir el delito. Porque no estamos hablando de un hipotético abuso en una investigación, sino de un procedimiento que tiene por regla el abuso.

No obstante, en las evidencias discursivas o prácticas que pesan contra la tortura en los trabajos policiales hay una situación que genera dudas en muchos policías, incluso entre los que son contrarios a la tortura: esto es, cuando existe una situación de riesgo de muerte de una tercera persona. Por ejemplo, un secuestrador fue encarcelado y no quiere decir dónde está la víctima ${ }^{135}$. En consecuencia ella puede morir de hambre o sed si la policía no la encuentra a tiempo. La duda expresada a partir de tal hipótesis teórica es la siguiente: ¿sería legítimo el uso de la tortura para salvar una vida? ¿Sería un típico caso de legítima defensa? Recordemos que esa es una situación extremadamente rara y que en todos los casos de tortura que llegaron a nuestro conocimiento, la policía usó la tortura, no para salvar vidas, sino para investigar crímenes ya ocurridos. Y, principalmente, crímenes patrimoniales.

Es importante llamar la atención sobre los crímenes que parecen ser más susceptibles de tortura. Al contrario de lo que podríamos imaginar de inmediato: que la búsqueda de solución para los crímenes más violentos fuera la regla, son los crímenes contra el patrimonio los que incentivan más la actuación de policías torturadores. ¿Cuál es la razón de eso? Posiblemente la recompensa. Al menos esa fue la explicación más común en las entrevistas.

\footnotetext{
135 Hubo un caso reciente en Alemania, dónde un niño fue secuestrado y la policía consiguió capturar al secuestrador, pero no sabía dónde estaba el niño. « La policía detuvo al asesino cuando se disponia a cobrar el dinero. Esperando aún poder encontrar con vida al pequeño, dos agentes que interrogaban a Gäfgen le amenazaron con 'grandes sufrimientos' si no revelaba dónde se encontraba el niño. El sospechoso confesó dónde habia escondido el cuerpo de la víctima. Gäfgen, que actualmente tiene 36 años, recibirá los 3.000 euros de indemnización porque los policías 'atentaron gravemente contra la dignidad humana' durante el interrogatorio, declaró el juez del Tribunal de Gran Instancia de Fráncfort, Christoph Hefter.». (TERRA, 2011).
} 


\section{Dimensiones histórico-sociológicas de la tortura en comisarías de Brasil: el caso Pernambuco}

\subsection{El debate sobre los justificantes "morales" esgrimidos para el uso de la tortura en casos "límite".}

Cuando se discute el principio de inaceptabilidad de la tortura no faltan quienes intentan contrastarlo con algunos ejemplos de actos terroristas que se plantean como desafíos teóricos a la posición de inflexibilidad ante esta práctica.

Son ejemplos hipotéticos, como el del avión lleno de pasajeros y con una bomba cuyo instalador terrorista estuviera preso y se negara a decir dónde está la bomba. Si no se descubriera a tiempo la ubicación de ésta, todos los pasajeros van a morir $^{136}$. ¿Es legítimo torturar al terrorista para que diga dónde está la bomba y así salvar cientos de vidas? ${ }^{137}$ Podemos sustituir ese ejemplo por muchos más, aunque sean muy raros, como el de una bomba puesta en una escuela de niños o el de una bomba en centros comerciales, etc.

Quienes formulan tales hipótesis lo hacen para plantear de inmediato la pregunta que viene a continuación: ¿No es justificable el sacrificio de un principio

\footnotetext{
136 “Imaginez qu'un terroriste ait été arrêté et qu'il soit, avec assez d'indices pour emporter une conviction raisonnable, suspecté d'avoir posé une bombe dans une école de la ville, imaginez que dans l'une de ces écoles se trouvent vos propres enfants. Toutes les méthodes d'interrogatoire légales ayant été employées en vain, l'homme se refusant à parler, ne serait-il pas légitime dans ce cas d'avoir recours à la torture?" (TERESTCHENKO, 2008: 73).

137 "Les penseurs, philosophes et juristes que nous convoquerons sont généralement des défenseurs ardents des droits civils, des libéraux progressistes, hostiles par principe à toute forme de violence ou de brutalité d'Etat, et parfaitement conscients que la torture est un mal. Mais, au nom du réalisme et du principe de responsabilité, ils concèdent que c'est parfois un mal nécessaire. Une nécessité qui s'impose en situation d'exception et d'urgence extrême, où l'on n'a tout simplement pas le choix des moyens, parce que des milliers de vies humaine sont en jeu, que le temps fait défaut et que toute solution alternative présente un risque qu'il serait totalement irresponsable de courir; ou encore, dans sa version utilitariste, qu'entre deux maux, il faut choisir le moindre.". (TERESTCHENKO, 2008: 11).
} 


\section{Dimensiones histórico-sociológicas de la tortura en comisarías de Brasil: el caso Pernambuco}

moral para salvar muchas vidas? ¿Por qué aceptamos con tanta tranquilidad que un criminal que está poniendo la vida de un rehén en peligro sea ejecutado por un tirador de élite y al mismo tiempo no aceptamos que un torturador profesional detenga con su método una información que salve vidas, quizá miles de vidas?

¿No estaríamos ante una situación en la que es mejor elegir el mal menor (torturar a alguien) para evitar un mal mayor (la muerte de inocentes)? ¿El respeto a la integridad física del terrorista o criminal es más importante que la vida de otra persona o muchas otras personas? Estaríamos - sostiene Terstchenko - ante el dilema de optar por dos posiciones: por un lado, la Kantiana con los principios imperativos categóricos; por el otro, la pragmática o realista evaluando los principios en razón de sus efectos sobre el número mayor de personas ${ }^{138}$.

¿Cómo podemos cambiar muchas vidas por el respeto a la integridad física de solamente un hombre, que, además, la puso en riesgo cuando asumió las consecuencias de su acto?

Cuando hablamos de principios siempre hay una posibilidad de conflicto entre distintos principios. Así podemos llegar a una difícil situación de tener que elegir uno. ¿La vida no es más importante que la integridad física? Algunos pensadores americanos hacen una defensa de la tortura cuando se destina a salvar vidas.

\footnotetext{
138 "Ainsi se trouvent mises en balance deux visions éthiques opposées. Pour le dire en bref, d'un côté, une conception déontologique des actions humaines (inspirée de la philosophie de Kant), qui dérive de principes impératifs catégoriques, indifférents à toute situation d'exception (position au fondement du droit international et de l'action des ONG de défense des droits de l'homme comme Amnesty International, Human Rights Watch, etc.); de l'autre, une conception qui se présente comme plus 'réaliste', évaluant ces principes en fonction de leurs effets sur le plus grand bien des personnes en fonction de leurs effets sur le plus grand bien des personnes concernées et qui admet que, dans certaines circonstances, ils peuvent et doivent même être suspendus."(TERESTCHENKO, 2008: 77).
} 


\section{Dimensiones histórico-sociológicas de la tortura en comisarías de Brasil: el caso Pernambuco}

Según Alan Dershowitz (2002), profesor de derecho de Harvard Law School y abogado conocido por la defensa de los derechos civiles, "es imposible de evitar el dilema moral de tener que elegir entre dos males", como por ejemplo, cuando hay una situación de terrorismo que pone en peligro la vida de muchas personas y tenemos que escoger entre la vida de las personas o el respeto a determinados principios. Para Dershowitz, en situaciones como esa, la tortura sería considerada un mal menor ${ }^{139}$, y, por eso mismo, un "bien".

Es una idea utilitarista que nos remite a Maquiavelo cuando cree que "mal" es aquello que reporta más problemas y sufrimientos para un mayor número de personas.

Dershowitz muestra una gran preocupación por la transparencia de los actos públicos, por la accountability del Estado. Por ello cree que cuando hay una regulación es posible establecer los límites y conocer mejor los abusos que cuando ello hace a escondidas, y peor aún, cuando los dirigentes saben que se hace y actúan como si no lo supieran. Dershowitz defiende por ello la regulación de la tortura y vincula su uso a la aprobación por un juez.

Es interesante señalar que con tales argumentos, la iniciativa americana de aprobar una ley que permitía la tortura, después de pasar por el Congreso americano, no hacía del acto de los EUA una aberración jurídica, sino que, todo lo contrario, se pudo presentar como un avance en lo que se refiere a la accountability.

Hay tres ideas básicas en la posición de Dershowitz: es decir, la necesidad de control público de los actos del Estado, la utilidad de la tortura en casos límite y el

139 "La réalité tragique est que la torture marche parfois, bien que beaucoup voudraient qu'il n'en soit pas ainsi. Il est de nombreux cas dans lesquels la torture a produit des informations véridiques, nécessaire à la prévention de maux envers des civils, et prouvant son efficacité" (DERSHOWITZ, 2002, 136). 


\section{Dimensiones histórico-sociológicas de la tortura en comisarías de Brasil: el caso Pernambuco}

reconocimiento de la moralidad de esa práctica. Para defender su posición se ampara en la premisa de evitar la arbitrariedad y la hipocresía ${ }^{140}$.

Frente a tales posicionamientos, Terestchenko afirma que hay una contradicción fundamental en la argumentación de Dershowitz cuando él hace un raciocinio utilitarista que plantea que cuando la tortura es un mal menor y necesario, eso quiere decir que ésta es un bien, una acción que debe ser aprobada y legalizada en ciertas circunstancias. Para él, en tal argumento hay una sobreimposición del Estado a la ley. Esto se produciría cuando, si el Estado no está cumpliendo la ley, cambiamos la ley, cuando es el Estado que debe someterse a ley.

Otro pensador americano, Michael Walzer ${ }^{141}$, uno de los filósofos americanos contemporáneos más influyentes, reconoce que la tortura puede producir informaciones útiles para la protección de vidas, pero no está de acuerdo con su reglamentación, ni tampoco con su prohibición absoluta.

Walzer reconoce que hay situaciones en las que puede ser útil la tortura, pero también reconoce el peligro de su regularización en razón de los principios ya establecidos y que son muy importantes para nuestra sociedad. Tampoco acepta que se ponga toda la responsabilidad y reproche social sobre el agente que tiene que tomar una decisión a favor de la comunidad.

Para Walzer, no debemos sacrificar los principios por la seguridad, pero tampoco los individuos que creen que es imprescindible tal acción. Para él, los responsables deben responder, individualmente, por la transgresión y asumir las consecuencias morales y penales de su decisión.

140 A pesquisadora norte-americana Kathrin Sikking revelou que no Brasil, à diferença de outros países da América latina, a polícia mata mais hoje, em plena democracia, do que no período militar. Mata porque pode matar. Mata porque nós continuamos a dizer tudo bem. (KEHL, 2011).

141 (WALZER, 1973). 


\section{Dimensiones histórico-sociológicas de la tortura en comisarías de Brasil: el caso Pernambuco}

Para Slavoj Zizek ${ }^{142}$ lo peor no es el uso de la tortura, que excepcionalmente pudiera ser aceptable como un acto humano y particular en situaciones extremas, sino la reglamentación o su utilización por el Estado. Esto es así porque, una vez aceptada y reglamentada, el mal ya estaría establecido como una necesidad inexorable. Walzer admite la posible necesidad ocasional de transgredir la regla de no torturar, pero jamás una reglamentación que la acepte como algo normal.

La discusión del uso de la tortura por el Estado, dejaría abierta, por lo tanto, al menos tres caminos: promulgar una ley que aceptase la tortura como un medio suplementario de obtención de informaciones en casos especiales; utilizar los excluyentes de ilicitud cuando ella fuera utilizada en condiciones justificadas; no aceptarla en ninguna situación.

Con la primera opción adoptaríamos la sugerencia de Dershowitz de reglamentar la tortura y con eso disminuir la arbitrariedad y la hipocresía. Es decir, establecer límites para evitar el abuso. Aumentar la seguridad desplazando la decisión de torturar o no, de los policías a los jueces. El problema es que no hay ninguna evidencia que demuestre que eso sea posible. Si hoy está prohibido y aun así se practica a menudo, no habría razón para pensar que si ampliamos la posibilidad de uso, ésta vaya a disminuir. Lo que parece es que ésta aumentaría puesto que pasaría a obtener un respaldo legal hasta entonces inexistente. O sea, el efecto probable sería el contrario del sugerido por Dershowitz. Así, una de las posibilidades sería que además de los casos ilegales de tortura que ya ocurrían antes, ahora en mayor número, tuviésemos también los casos "legales", practicados por quien antes no los practicaba. Es demasiado peligroso porque transformaríamos algo que es considerado bárbaro y criminal para considerarlo como un medio procesal. Es como

$142 \quad$ (ZIZEK, 2007). 


\section{Dimensiones histórico-sociológicas de la tortura en comisarías de Brasil: el caso Pernambuco}

si hubiéramos retrocedido dos siglos hacia atrás. Y peor aún, caminaríamos hacia una banalización del mal.

La segunda posibilidad sería aplicar los excluyentes de ilicitud a la tortura una vez cumplidos todos los requisitos: utilización de la tortura como defensa contra una agresión injusta, actual e inminente; que no se haya dado causa; proporcionalidad de los medios. Así es, habría delito, pero no habría punición, por la presencia de los excluyentes de ilicitud. Los mismos principios que se aplican a los demás crímenes.

Veamos el ejemplo del homicidio en legítima defensa. Matar está prohibido pero no es una prohibición absoluta. Es delito pero hay casos en los que es posible que haya una excluyente de ilicitud. Por ejemplo, cuando se mata para proteger a otra vida.

En verdad se trata de un principio ya previsto en prácticamente todos los códigos penales como causas excluyentes de ilicitud. $\mathrm{O}$ sea, el acto practicado es considerado delito, pero en caso de que estén presentes determinadas circunstancias el agente será beneficiado por una exclusión de la ilicitud.

\section{Exclusão de ilicitude}

Art. 23. Não há crime quando o agente pratica o fato:

I - en Estado de necessidade;

II - en legítima defesa;

$[\ldots]$

"Excesso punivel

Parágrafo único: $O$ agente, en qualquer das hipóteses deste artigo, responderá pelo excesso doloso ou culposo."

Estado de necessidade 


\section{Dimensiones histórico-sociológicas de la tortura en comisarías de Brasil: el caso Pernambuco}

Art. 24. Considera-se en Estado de necessidade quem pratica o fato para salvar de perigo atual, que não provocou por sua vontade, nem podia de outro modo evitar, direito próprio ou alheio, cujo sacrifício, nas circunstâncias, não era razoável exigir-se.

$\S 1$. Não pode alegar o Estado de necessidade quem tinha o dever legal de enfrentar o perigo.

$\S$ 2..Embora seja razoável exigir-se o sacrifício do direito ameaçado, a pena poderá ser reduzida de um a dois terços.

Legítima defesa

Art. 25. Entende-se en legítima defesa quem, usando moderadamente dos meios necessários, repele injusta agressao, atual ou iminente, a direito seu ou de outrem.

[CÓDIGO PENAL BRASILEIRO].

Se trata de un postulado presente en todos los códigos occidentales y no hay diferencia entre la legítima defensa del código brasileño y el español.

Art. 20. Están exentos de responsabilidad criminal:

[...]

4.. El que obre en defensa de la persona o derechos propios o ajenos, siempre que concurran los requisitos siguientes:

Primero. Agresión ilegítima. En caso de defensa de los bienes se reputará agresión ilegítima el ataque a los mismos que constituya delito o falta y los ponga en grave peligro de deterioro o pérdida inminentes. En caso de defensa de la morada o sus dependencias, se reputará agresión ilegítima la entrada indebida en aquélla o éstas.

Segundo. Necesidad racional del medio empleado para impedirla o repelerla.

Tercero. Falta de provocación suficiente por parte del defensor.

5... El que, en Estado de necesidad, para evitar un mal propio o ajeno lesione un bien jurídico de otra persona o infrinja un deber, siempre que concurran los siguientes requisitos:

Primero. Que el mal causado no sea mayor que el que se trate de evitar.

Segundo. Que la situación de necesidad no haya sido provocada intencionalmente por el sujeto.

Tercero. Que el necesitado no tenga, por su oficio o cargo, obligación de sacrificarse.” 


\section{Dimensiones histórico-sociológicas de la tortura en comisarías de Brasil: el caso Pernambuco}

[Código Penal Español]

Por ese principio, cualquiera puede matar a una persona que está poniendo en riesgo la vida de un tercero. Tenemos una situación en la que se cambia una vida por una vida. No necesitamos pasar por nuevos debates filosóficos sobre lo que es posible o no para salvar una vida puesto que el tema ya ha sido suficientemente discutido $^{143}$.

Finalmente nos planteamos la tercera opción, de no tolerar la tortura en ninguna circunstancia. Tal es la apuesta de muchos teóricos que van en la dirección del discurso internacional de los Derechos Humanos ${ }^{144}$.

Veamos el artículo 2.2 de la Convención Contra la Tortura y Otros Tratos o Penas Crueles Inhumanos o Degradantes:

“Art. $2^{\circ}$.

$1[\ldots]$

143 Es dominante la creencia en la existencia de un doble fundamento: por una parte individual, como expresión de un derecho subjetivo, de origen romano, y por otra parte colectivo, vinculado a la idea de defensa del orden jurídico, de raigambre germánica. La perspectiva colectiva se expresa en la idea hegeliana de que 'el Derecho no tiene por qué ceder al injusto' y parte del presupuesto de la atribución al sujeto de un poder de auto tutela ahí donde el titular de la potestad punitiva no se encuentra presente para hacer frente a un ataque al orden jurídico (lo cual, remontándonos a una concepción contractualista como la de Rousseau se plantearía como una recuperación momentánea del Estado previo al contrato social). (SUMALLA, 2008: 214).

144 "El derecho a la vida puede, legítima aunque restrictivamene, ser transgredido en la guerra. Además, los instrumentos internacionales no han derogado la pena de muerte, a pesar de su vocación abolicionista.

La prohibición de la tortura, en cambio, es absoluta. Absoluta en la paz y absoluta en la guerra. El derecho no autoriza circunstancia alguna en que pueda ser transgredida". (GARRETÓN, 2004: 145). 


\section{Dimensiones histórico-sociológicas de la tortura en comisarías de Brasil: el caso Pernambuco}

2. En ningún caso podrán invocarse circunstancias excepcionales tales como Estado de guerra o amenaza de guerra, inestabilidad política interna o cualquier otra emergencia pública como justificación de la tortura."

Aún más explícita es la Convención Interamericana para Prevenir y Sancionar la Tortura de 1986:

“Art. $5^{\circ}$.

No se invocará ni admitirá como justificación del delito de tortura la existencia de circunstancias tales como Estado de guerra, amenaza de guerra, Estado de sitio o de emergencia, conmoción o conflicto interior, suspensión de garantías constitucionales, la inestabilidad política interna u otras emergencias o calamidades públicas.

Ni la peligrosidad del detenido o penado, ni la inseguridad del establecimiento carcelario o penitenciario pueden justificar la tortura."

Para algunos intérpretes de la ley penal, esto englobaría las excluyentes de ilicitudes que tampoco podrían ser arguiidas. Para otros no, pues lo que esos tratados establecen son directrices a las que los Estados están obligados a cumplir incluso en períodos de excepción, y no hay una mención explícita en los tratados o convenciones a las excluyentes de ilicitudes - técnica contenida en la parte general de los códigos penales y, referente a los individuos-. Y si no se veta de forma explícita, no podemos excluir por lo tanto que se trata de un derecho del acusado que no podemos restringir. Interpretar tal negación como absoluta implicaría para ellos reconocer que si un agente público practica la tortura contra un psicótico, terrorista o secuestrador que mantiene a alguien en cautiverio, bien sea en un avión lleno de pasajeros o una escuela de niños, este agente público que la practica en cualquier de esas circunstancias no tendrá ningún atenuante por su acto. 


\section{Dimensiones histórico-sociológicas de la tortura en comisarías de Brasil: el caso Pernambuco}

Por el contrario, si rechazamos la aplicación de los excluyentes de ilicitud para ese caso nos encontraríamos con la situación en la que un agente que practicase un acto motivado por salvar vidas tendría una pena más alta que una persona que torturase por un motivo menor o torpe, pues la legislación brasileña consideró la tortura como un delito común, que puede ser cometido por cualquiera, incluso por los particulares $^{145}$, sin embargo, para los empleados públicos que actúan en razón de sus trabajos, la pena es más grave.

Había también una discusión respecto al peso de los tratados sobre la legislación brasileña ${ }^{146}$, cuestión que ya está resuelta con la introducción del $\S 3^{\circ}$ del Art. $5^{\circ}$ que definió la situación de los tratados y convenciones internacionales ${ }^{147}$.

Aunque quien practica la tortura para salvar vidas pudiera ampararse en el excluyente de ilicitud, apoyándose en que no hay una norma que diga lo contrario y que no podemos hacer una interpretación penal restrictiva para perjudicar el acusado, eso jamás podría servir para un caso de tortura en una investigación, como ocurre a menudo en Brasil, puesto que en esos casos además de las razones expuestas más

145 Hay, en Brasil, una divergencia doctrinal sobre la inconstitucionalidad o no de la inclusión de los particulares, como autores del delito, en la Ley de Tortura, una vez que las convenciones sólo se refieren al empleado público o agente del Estado. La idea de algunos especialistas es que como la CF de Brasil ratificó los tratados y convenciones internacionales relativos a los derechos humanos, la norma penal brasileña no podría ser divergente de tales tratados. Según nuestra opinión, no hay ninguna incompatibilidad ya que la norma brasileña no restringe los tratados, sino todo lo contrario, va más allá que éstos. Todo eso está en consonancia con los Tratados que admiten explícitamente, aunque no sea necesario, que los países signatarios amplíen la protección en sus ordenamientos ordinarios.

146 "Há quatro correntes acerca da hierarquia dos tratados de proteção dos direitos humanos, que sustentam: a) a hierarquia supraconstitucional destes tratados; b) a hierarquia constitucional; c) a hierarquia infraconstitucional, mas supralegal $e ; d)$ a paridade hierárquica entre tratado e lei federal." (PIOVESAN, 2002: 94).

$147 \quad$ Art. $5^{\circ}, \$ 3^{\circ}$. : Os tratados e convenções internacionais sobre direitos humanos que forem aprovados, em cada Casa do Congresso Nacional, em dois turnos, por três quintos dos votos dos respectivos membros, serão equivalente às emendas constitucionais.” (CF, 1988). 
Dimensiones histórico-sociológicas de la tortura en comisarías de Brasil: el caso Pernambuco

arriba sobre la ineficiencia de la tortura, faltarían también otros requisitos que permitiesen la utilización de excluyentes de ilicitudes. 


\section{Dimensiones histórico-sociológicas de la tortura en comisarías de Brasil: el caso Pernambuco}

\subsection{Conclusión}

La intención en ese capítulo no fue la de tomar posición sobre el tema, sino mostrar las discusiones existentes respecto a él y que la prohibición absoluta es objeto de polémica, aceptando algunos autores la tortura sin dar la espalda a las discusiones "morales", con las que se pretende legitimarla. Pero las discusiones tratan de una posibilidad que es muy poco frecuente: torturar para salvar una vida. Y tal como los excluyentes de responsabilidad, se exige para tal excusa el potencial de peligro concreto, inmediato y la proporcionalidad de la agresión. Y esa situación en que la tortura es considerada por algunos "aceptable" es excepcional y inusual. Excepto en el ejemplo ocurrido en Alemania (pág. 83) no hemos tenido noticia de ningún caso así en Brasil u otras partes del mundo.

Frente a esa posibilidad rara, en Brasil, la costumbre extendida en la Policía Judicial es la práctica de tortura para investigar crímenes ya ocurridos, en su gran mayoría crímenes patrimoniales, donde ningún teórico hablaría ninguna posibilidad de "excusas" para tal práctica. No se trata de conflicto de principios donde se elige entre torturar o preservar vidas. Se trata de una ausencia de principios, pues se tortura porque resulta más sencillo, "práctico", y las personas torturadas no son consideradas, por los policías, como portadoras de derechos o siquiera "personas". Los policías no ven conflictos de principios y si una oportunidad de ganancia, directamente a través de recompensas o incluso de la apropiación indebida de los bienes sustraídos, o indirectamente (a través de elogios, promociones y ascensos profesionales). 


\section{Dimensiones histórico-sociológicas de la tortura en comisarías de Brasil: el caso Pernambuco}

\section{CULTURA CORPORATIVA}

La cultura corporativa ${ }^{148}$ es un conjunto de valores, creencias, ideologías, hábitos, costumbres y normas que comparten los individuos en la corporación y surgen de la interacción social, generando patrones de comportamiento colectivos que establecen una identidad entre sus miembros, identificándolos con la corporación a cual pertenecen y diferenciándolos de las otras. Es una manera, formal e informal, compartida de percibir la vida y la participación en la corporación, que mantiene a sus miembros unidos e influye en lo que piensan de sí y de su trabajo.

El término "cultura" sugiere, en este caso, un conjunto de valores, creencias, rituales, símbolos y conductas apreciadas por el colectivo de una corporación ${ }^{149}$. A los cuales Freitas ${ }^{150}$ añade los ritos, ceremonias, historias y mitos, tabúes, héroes, normas y comunicación.

Los "valores" son las definiciones de lo que es importante para que la organización alcance el éxito. Las "creencias" son los términos usados como

148 Según Robles, "los grupos humanos desarrollan sistemas culturales que contienen reglas de conducta, valores morales o sentidos de identidad. En las sociedades industrializadas, las instituciones, organizaciones, grupos profesionales o medios de comunicación de masas tienen un papel clave en la producción y reproducción de valores. La importancia de los valores consiste en que son depositarios de pautas colectivas de acción y reflexión”. (ROBLES, 1009: 43).

149 “ Cerimônias: eventos especiais nos quais os membros de uma organização celebram os mitos, heróis e símbolos da empresa; ritos: atividades cerimoniais destinadas a comunicar idéias específicas ou a realizar determinados propósitos; rituais: ações regularmente repetidas para reforçar normas $e$ valores culturais; historias: relatos de eventos passados que ilustram e transmitem normas e valores culturais mais profundos ;mitos: historias imaginárias que ajudam a explicar atividades ou eventos que de outro modo poderiam ser confusos; heróis: as pessoas de sucesso que corporificam os valores e o caráter da organização e de sua cultura; símbolos: objetos, ações ou eventos dotados de significados especiais e que permitem aos membros da organização trocarem idéias complexas e mensagens emocionais; linguagem: um conjunto de símbolos verbais que geralmente reflete a cultura particular da organização”. (WAGNER III \& HOLLENBECK, 2003:).

$150 \quad$ (FREITAS, 1991). 


\section{Dimensiones histórico-sociológicas de la tortura en comisarías de Brasil: el caso Pernambuco}

sinónimo para expresar "aquilo que é tido como verdade na organização"151. El concepto de Deal \& Kennedy ${ }^{152}$ en que los "ritos", "rituales" y "ceremonias" son ejemplos de actividades planeadas que tienen consecuencias prácticas expresivas, haciendo que la cultura organizacional sea más tangible y cohesionada, dando sentido a cualquier acontecimiento. Considera a las historias como narrativas basadas en eventos ocurridos, que informan sobre la organización, refuerzan el comportamiento existente y dan énfasis al ajuste de ese comportamiento con el ambiente de la organización. Los "mitos" se refieren a las historias consistentes con los valores de la organización, no sostenidos por los hechos. Los "tabúes" ponen en evidencia el aspecto disciplinar, con énfasis en lo permitido. Los "héroes", para Deal \& Kennedy ${ }^{153}$, personifican los valores y condensan la fuerza de la organización. Según ellos, los héroes hacen que el éxito sea accesible y humano, aportan modelos, simbolizan la organización para el mundo exterior, preservan lo que la organización tiene de especial, establecen patrones, motivan a los empleados, y, influyen por mucho tiempo en la organización. Las normas son denominadas por Robert F. Allen como "todo o comportamento que é esperado, aceito ou apoiado pelo grupo, esteja tal comportamento fixado formalmente ou não. Assim a norma é o comportamento sancionado, através do qual as pessoas são recompensadas ou punidas, confrontadas ou encorajadas, ou postas em ostracismo quando violam as normas" (apud Freitas, 1991:33). La “comunicación”, analizada por Freitas (1991), es considerada como el proceso inherente a las organizaciones que crea una cultura, que se da a través de una red formal o informal, que hace efectiva la cultura corporativa.

En el proceso de ayudar a crear una comprensión mutua de la vida de la corporación, la cultura corporativa actúa con cuatro funciones básicas. Primero, da a los miembros una identidad organizacional. Compartir normas, valores y

\footnotetext{
$151 \quad$ Idem: 19.

152 (DEAL \& KENNEDY, 2000).

153 Idem.
} 


\section{Dimensiones histórico-sociológicas de la tortura en comisarías de Brasil: el caso Pernambuco}

percepciones proporciona a las personas un sentido de unión que ayuda a promover un sentimiento de objetivo común. Segundo, facilita el compromiso colectivo, el propósito común que se desarrolla desde una cultura compartida puede propiciar un sólido compromiso en todos aquellos que aceptan la cultura como la suya propia. Tercero, promueve la estabilidad corporativa: Al alimentar el sentido común de identidad y compromiso, la cultura favorece la permanente integración y cooperación entre los miembros de una corporación. Cuarto, moldea el comportamiento al ayudar a los miembros a dar sentido a sus ambientes. La cultura de una corporación sirve como una fuente de significados comunes para explicar por qué las cosas ocurren del modo como ocurren.

¿Cómo se expresan esas normas y valores fundamentales? ¿Cómo se transmiten de una persona a otra? Según Dias (2007) la cultura corporativa debe su existencia a dos factores: la voluntad consciente o inconsciente de sus fundadores transmitida a cada generación y el aprendizaje de sus miembros a lidiar con situaciones críticas de lo cotidiano. Ciertos elementos superficiales de la cultura ayudan a sus miembros a interpretar eventos cotidianos en la corporación y son los principales medios por los cuales las normas y los valores culturales son comunicados de una persona a la otra.

Sin embargo, no podemos creer que en una corporación de grandes dimensiones y descentralizada como la policía, va existir solamente una cultura ${ }^{154} \mathrm{o}$ la cultura de los “fundadores". Martin y Frost ${ }^{155}$ sostienen la idea de la posible existencia de una o diversas culturas en una corporación. Tal crítica viene de las limitaciones inherentes a un universo consensual y armonioso, así como de las distorsiones que nacen de un modelo ideal y monolítico de ver, actuar e interpretar el

$154 \quad$ Outros autores, como Nystron (1986), Schall (1983), Miller (1986), Davis (1984), Gregory (1983), Meyerson e Martin (1987) e Riley (1983), também partilham da existência de múltiplas culturas em uma mesma organização. (FREITAS, 2007: 45).

155 (MARTIN Y FROST, 2001). 


\section{Dimensiones histórico-sociológicas de la tortura en comisarías de Brasil: el caso Pernambuco}

mundo a partir de la perspectiva de un grupo muy específico como la alta dirección de una corporación o de sus fundadores, dejando para los demás miembros la repetición continua de aquello que ellos aceptaran como verdad absoluta.

La cultura de una corporación no existe cuando esta empieza, pues su formación se da de forma gradual a través del tiempo y jamás termina. La formación y consolidación de una cultura corporativa están directamente ligadas a la permanencia de un cierto grupo de empleados. En una organización donde hay un cambio excesivo de miembros difícilmente se llegan a consolidar valores, pues la formación de la cultura se produce en el contexto de las relaciones interpersonales.

En toda organización formal de cargos y relaciones estructurales, hay una organización informal de reglas, procedimientos y relaciones no oficiales. Esa organización informal es perceptible cuando los miembros hacen cambios espontáneos, no autorizados, en la manera de hacer las cosas. En la medida que esos cambios moldean y alteran la manera formal de proceder, surge una cultura de actitudes y nociones que pasa a ser compartida entre colegas de trabajo. Morais ${ }^{156}$ recuerda que el universo cultural de las organizaciones, mismo las burocráticas, no se limita a las normas y valores formalizados, ni a lo ceremoniales propios de esas instituciones. En verdad, todo el acervo no escrito, pero incorporado a la História, así como las creencias orales de los integrantes, incluso lendas y tabúes, consolidan la llamada cultura corporativa.

La cultura puede ser un patrón de suposiciones básicas - inventadas, descubiertas o desarrolladas por los miembros de una corporación para lidiar con problemas de adaptación externa e integración interna - que funcionan con eficacia suficiente para ser consideradas válidas y, después, son enseñadas a los nuevos miembros como la manera correcta de percibir, pensar y sentir esos problemas.

$156 \quad$ (MORAIS, 2008). 


\section{Dimensiones histórico-sociológicas de la tortura en comisarías de Brasil: el caso Pernambuco}

Como sostiene $\operatorname{Schein}^{157}$, la cultura corporativa es un producto que surge con la experiencia grupal y sin el grupo, no puede existir cultura y, sin la existencia de un cierto grado de cultura en realidad, todo lo que podemos hablar es de un montón de personas y no de un grupo ${ }^{158}$.

En la medida que se produce la constitución de un grupo se dará manifestación de determinadas formas de pensamientos, valores, que son el resultado de la experiencia compartida en el modo de hacer las cosas Así la cultura corporativa, como otra cualquiera, es un producto de un proceso histórico y social de experiencias vividas y acumuladas por la corporación y transmitidas a las nuevas generaciones de miembros a través de un proceso de socialización (DIAS, 2007).

Los valores, creencias y patrones de comportamiento son características determinantes en cualquier organización, porque forman su núcleo, su identidad. Pero si aplicamos la metáfora de un iceberg, los patrones de comportamiento de las personas reflejan la punta de ese, que es visible y, por eso, más vulnerable a las transformaciones del ambiente. Los valores y las creencias constituyen la base sumergida más protegida $\mathrm{y}$, al mismo tiempo, con mayores dificultades para ser modificada $^{159}$. A lo largo de la trayectoria de una organización se van a constituir un conjunto complexo de tradiciones, hábitos, costumbres, opiniones, actitudes, prejuicios, reglas, modos típicos de arreglar problemas..., que pueden ser comprendidos en cuatro grupos:

\footnotetext{
$157 \quad$ (SCHEIN, 1992).

158 "A cultura organizacional é o modelo de pressupostos básicos, que determinado grupo tem inventado, descoAl ou desenvolvido no processo de aprendizagem para lidar com os problemas de adaptação externa e adaptação interna. Uma vez que os pressupostos tenham funcionado bem o suficiente para serem considerados válidos, são ensinados aos demais membros como a maneira correta para se perceber, se pensar e sentir-se em relação àqueles problemas”. (Schein, 2001:07).
} 159 (ARAÚJO \& GARCIA, 2009: 316). 


\section{Dimensiones histórico-sociológicas de la tortura en comisarías de Brasil: el caso Pernambuco}

- “sistema normativo, refiriéndose a los mecanismos de regulación en los niveles de poder, de la autoridad y de la decisión; el conjunto de reglas y valores que conducen la vida organizacional, incluyendo política administrativa, estilos gerenciales, o costumbres sociales, rituales, tradiciones, tabúes, dogmas, puniciones o conductas esperadas;

- el conjunto de las disciplinas organizacionales, cuáles sean: los modos de organización del espacio y del control del tiempo, así como los mecanismos de vigilancia internalizada;

- el saber tecnológico, que trata de los instrumentos y procesos propios y específicos de la naturaleza de la actividad organizacional, incluyéndose el lenguaje especializado, las metodologías de trabajo o del dominio de instrumentos y técnicas;

- el modo peculiar como se estructura la red de vínculos, lo que incluye los patrones de interacción afectiva y los procesos de establecimiento, valorización o interrupción en el campo de las relaciones interpersonales." 160

Esos fenómenos se interconectan construyendo la trama de la tela de la organización, donde actúan tanto elementos deseables cuanto destructibles. En una organización grande y con un grado de informalidad muy alto, como la policía, la cultura corporativa es un aspecto esencial para comprender su ethos. Internamente fomentan y mantienen sistemas de valores mediante roles, ritos o carreras personales como medio para aumentar la cohesión, el control y el funcionamiento coordinado ${ }^{161}$.

Según Rivera ${ }^{162}$, la cultura corporativa ${ }^{163}$ representa lo que puede y lo que no puede ser hecho dentro de la organización, afirmando que la cultura corporativa es

160 (CARDOSO \& CUNHA, 2001: 92).

161 La cultura organizativa crea un orden colectivo donde se restringen las opciones y donde se aprenden, reproducen y legitiman pautas de comportamiento y de pensamiento. (BERGER \& LUCKMANN, 1968).

162 (RIVERA, 1994: 38).

163 Según Torquato, la cultura corporativa es "o somatório dos inputs técnicos, administrativos, políticos, estratégicos, táticos, misturados às cargas psicossociais, que justapõem fatores humanos individuais, relacionamentos grupais, intergrupais e informais" (1991:03). 


\section{Dimensiones histórico-sociológicas de la tortura en comisarías de Brasil: el caso Pernambuco}

un conjunto de valores implícitos que ayudan las personas en la corporación a comprender que acciones son consideradas aceptables y cuales son consideradas inaceptables. Para Torquato ${ }^{164}$ la cultura corporativa es "o somatório dos inputs técnicos, administrativos, políticos, estratégicos, táticos, misturados às cargas psicossociais, que justapõem fatores humanos individuais, relacionamentos grupais, intergrupais e informais".

Un buen ejemplo son los rituales de entrega de medallas, diplomas o elogios oficiales, pues, en general, son una buena muestra de los valores explícitos y ocultos de una corporación. También forman parte de la cultura de una corporación los espacios físicos: edificios, distribución de oficinas, uso del espacio, etc. Así, la cultura corporativa es el conjunto de valores, creencias y entendimientos importantes que los integrantes de una corporación tienen en común, determinando formas de actuación de acuerdo con tales valores ${ }^{165}$. Para nuestro trabajo dividiremos la cultura en dos partes: incentivos y medios disuasorios. Buscamos evidencias de que en las actividades diarias de la organización inducen a determinados comportamientos a través de prácticas, rituales y ejemplos (comúnmente caracterizados como cultura

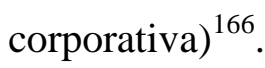

\footnotetext{
164 (TORQUATO, 1991: 03).

165 Podemos dizer que a cultura organizacional é um sistema de valores e crenças compartilhadas que interage com pessoas, estruturas da organização, processos de tomada de decisões e sistemas de controle de uma empresa para produzir normas de comportamento (de como devem ser feitas as coisas numa organização em particular). (DIAS, 2007: 41).

$166 \quad$ "Nosso próprio estudo de caso das atrocidades policiais durante o período militar no Brasil postula que una busca das causas das atrocidades - quer nos Estados autoritários militares, quer em democracias emergentes ou consolidadas - deve ir além da perspectiva simplista e personalista da "maçã podre", ou da vaga perspectiva de uma "excepcional cultura da violência" disseminada por toda a sociedade. Nenhuma delas - nem a perspectiva psicobiológica, nem a determinista cultural geral - responde pelos efeitos dos sistemas burocratizados que permitem ou estimulam os mecanismos sóciopsicológicos e culturais que podem engendrar a conduta policial violenta e que concedem impunidade tanto aos perpetradores quanto aos facilitadores. Algumas pesquisas sobre a violência policial nos Estados Unidos têm indicado poucas teorias explicativas viáveis como alternativa a essas perspectivas inadequadas - por exemplo, as que situam a violência policial dentro
} 


\section{Dimensiones histórico-sociológicas de la tortura en comisarías de Brasil: el caso Pernambuco}

\subsection{La Cultura Corporativa en el contexto de la Teoría Económica del Delito}

El gran desafío para este capítulo es cómo contextualizar el aprendizaje corporativo u organizacional - Teoría de la Cultura Corporativa, con una teoría que explique por qué las personas eligen practicar un delito - Teoría del delito. Debemos recordar que no tratamos del delito en toda su generalidad, pero de un delito específico: la tortura. Y con otra especificidad: todos los autores son policías licenciados en Derecho, es decir, con conocimiento legal. El camino que nos pareció más natural fue trabajar con teorías que fueran compatibles con la cultura corporativa y, casi todas lo eran. Entonces buscamos las que tenían focos más específicos que se acercaban de la cultura corporativa y dos se acercaban mucho: "Teoría de la Economía del Delito"167 y "Teoría de las Abordagens de Actividades Rutineras"

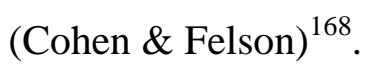

de "culturas operacionais", "estilos de liderança” e "mandados organizacionais". Contudo, embora em sua maioria essas teorias permitam uma compreensão imediata de algumas situações de violência policial, não conseguem explicar de modo adequado os apoios estruturais em maior escala dados às atrocidades praticadas por forças de segurança. Ao contrário, são as perspectivas menos viáveis que predominam na maioria das explicações da mídia sobre atrocidades policiais, ao mesmo tempo em que informam algumas análises acadêmicas e freqüentemente dão forma aos argumentos legais utilizados na defesa ou na condenação de policiais violentos.” (HUGGINS, 2006: 33).

167 Según Becker, hay una elección racional, valorándose ganancias y pérdidas que pueden derivarse de la práctica de un delito. El individuo elige entre prácticas lícitas o ilícitas de acuerdo con las ventajas y desventajas o de los incentivos positivos o negativos resultantes de tales prácticas. Para Becker, el criminal evalúa las consecuencias de la práctica criminal y sólo la realiza si los benefícios esperados excedieren los costos por tal acto criminal. (BECKER, 1968).

168 Para que un delito ocurra es necesario una convergencia en el tiempo y espacio de tres elementos: ofensor motivado, que, por alguna razón esté dispuesto a cometer un delito; objetivo disponible, ente, o persona, que pueda ser atacada; y ausencia de guardianes que sean capaces de prevenir delitos. (COHEN \& FELSON, 1979: 588-608). 


\section{Dimensiones histórico-sociológicas de la tortura en comisarías de Brasil: el caso Pernambuco}

Aunque la conclusión del trabajo se acerque mucho de la "Teoría Ecológica del Delito" 169 hay una dificultad de ajuste entre la cultura corporativa y la teoría ecológica en razón del carácter generalista de la teoría ecológica: múltiples factores ayudan a condicionar a un individuo a actuar en las más diversas conductas delictivas. En nuestro estudio no buscamos la generalización. Buscamos explicaciones para un único tipo de delito: la tortura, practicado por un tipo muy específico de autor: policías sometidos a una experiencia corporativa única: la organización policial ${ }^{170}$. Como se trata de torturadores de diversos Estados de Brasil, con experiencias de vida y condiciones sociales y culturales muy distintas, lo que dificultaba encontrar patrones de influencia, buscamos el elemento común a todos: la organización en que trabajaban y el conocimiento de la ley.

Así que optamos por combinar la Teoría de la Cultura Corporativa con la Teoría de la Economía del Delito. Creamos dos grupos que tratan de las "ventajas" y “desventajas" de la práctica de la tortura. A las ventajas les llamaremos: incentivos

169 Bronfenbrenner (1987) propone una perspectiva ecológica del desarrollo de la conducta humana. Esta perspectiva concibe al ambiente ecológico como un conjunto de estructuras seriadas y estructuradas en diferentes niveles, en donde cada uno de esos niveles contiene al otro. Bronfenbrenner denomina a esos niveles el microsistema, el mesosistema, el exosistema y el macrosistema. El microsistema constituye el nivel más inmediato en el que se desarrolla el individuo (usualmente la familia); el mesosistema comprende las interrelaciones de dos o más entornos en los que la persona en desarrollo participa activamente; al exosistema lo integran contextos más amplios que no incluyen a la persona como sujeto activo; finalmente, al macrosistema lo configuran la cultura y la subcultura en la que se desenvuelve la persona y todos los individuos de su sociedad. Bronfenbrenner (1987) argumenta que la capacidad de formación de un sistema depende de la existencia de las interconexiones sociales entre ese sistema y los otros. Todos los niveles del modelo ecológico propuesto dependen unos de otros y, por lo tanto, se requiere de una participación conjunta de los diferentes contextos y de una comunicación entre ellos. (BROFENBRENNER, 1987)

170 Ratton, al hablar de la teoria organizacional moderna y de como los mecanismos internos a las organizaciones policiales favorecen y posibilitan prácticas profesionales violentas, afirma que "se quisermos aplicar tal formulaçao geral ao caso das Polícias, perceberemos a existencia de alguns traços organizacionais recorrentes nas polícias - perigo, autoridade e eficiencia - que se combinam para gerar respostas comportamentais próprias a polícia, configurando o que talvez possa ser chamado de uma 'personalidade ocupacional"'. (RATTON, 2007: 141). 


\section{Dimensiones histórico-sociológicas de la tortura en comisarías de Brasil: el caso Pernambuco}

para la tortura, con los subgrupos de "asimilación de tortura", "presunta eficiencia del método", "ascenso/prestigio" y "corrupción”. A las desventajas les llamaremos: "métodos disuasorios de la tortura", con los subgrupos "presión interna", "presión externa". Así tenemos los incentivos positivos y negativos para la práctica del delito.

No creemos plausible que la práctica de un delito se deba tan sólo a un proceso racional de análisis de pérdida y ganancia, o a los costes socio-económicos resultantes de la impunidad o punibilidad. Hay otras teorías, que incluso hacen el planteamiento contrario ${ }^{171}$. Pero, en ese caso específico, el de los comisarios, nos parece que es la teoría más razonable, pues todos tienen conocimientos jurídicos, no están obligados a seguir ninguna orden o encargo ilegal, como licenciados en Derecho ellos lo saben muy bien y además ellos son los jefes de sus equipos y tienen una visión muy clara de las probalidades de éxito de acciones criminales. ¿Por qué iban a poner sus carreras en riesgo, incluso sus libertades, para usar la tortura cómo medio de investigación sin obtener algo a cambio?

\footnotetext{
171 "Inicialmente, o ato de cometer um crime, ou seja, violar uma regra socialmente aceita, pode ou não envolver um custo moral. Mesmo que do ponto de vista financeiro a melhor decisão pareça ser a opção pelo mercado ilícito, a inclusão de um custo moral no modelo pode criar a barreira necessária para a entrada neste mercado. Block e Heinecke (1975) apud Cerqueira e Lobão (2003b) destacam que existem diferenças éticas e psicológicas envolvidas no processo de decisão do indivíduo na escolha entre os mercados lícitos e ilícitos e, portanto, o processo de decisão envolve certamente um aspecto moral. A eficiência do custo moral como barreira à entrada na atividade ilícita é condicionada a um julgamento moral executado pelo indivíduo sobre seu ato. Surge então a necessidade de entender como se processa no indivíduo a construção deste julgamento. Neste ponto, os economistas têm muito a aprender com outras ciências, tais como a sociologia, a antropologia, mas principalmente, com a psicologia.” (OLIVEIRA (b), 2005: 04).
} 


\section{Dimensiones histórico-sociológicas de la tortura en comisarías de Brasil: el caso Pernambuco}

\subsubsection{Incentivos a la tortura}

\subsubsection{Asimilación de la tortura}

Hemos preguntado a los entrevistados por los incentivos que llevan a torturar a los policías. En un primer bloque de preguntas buscamos su percepción sobre la existencia, o no, de la tortura en las comisarías. Si la tradición cultural brasileña apuntaba a una continuación de la práctica de la tortura frente a los sospechosos "no ciudadanos", después de las entrevistas que siguen, tal teoría resulta mucho más evidente.

Habiéndoseles preguntado si conocían a algún policía que practicara la tortura, todos los entrevistados contestaron de forma positiva:

Conozco, conozco. $(C 1){ }^{\text {viii }}$

Sí. En convivio personal. (C2). ${ }^{\text {ix }}$

Conozco a varios. Agentes y comisarios. Algunos que la practican ocasionalmente, otros frecuentemente y, hasta un comisario psicópata. Sin hablar de aquellos que saben que los agentes la practican y fingen que no saben nada. (C3). ${ }^{\mathrm{x}}$

Hay, desafortunadamente todavía existen policías con ese tipo de mentalidad... Los conocí y ya oí hablar de ellos. Mira, hay algunos que por lo que yo oí, según ellos sólo conseguirían resolver aquel crimen con la información del autor, Entonces por eso intentaban por esa práctica obtener la información. Sé de otro que yo creo que debe tener algún disturbio mental. Porque hace cosas que no son necesarias hacerlas. Y así, no hay justificativa. Es 


\section{Dimensiones histórico-sociológicas de la tortura en comisarías de Brasil: el caso Pernambuco}

como si fuera solo cuestión de que le hace bien a él, ver a otro ser sometido a determinados sufrimientos físicos. (CA6). ${ }^{\mathrm{xi}}$

Sí. Lo supe a través de otros policías. En nuestra institución hay policías que se hicieron famosos y hasta respetados por el uso de la tortura. (C4). ${ }^{\text {ii }}$

$\mathrm{Si}$, casi todos los policías cuando no tienen elementos científicos probatorios suficientes para formular un informe sobre la investigación, acaban por recurrir a prácticas de “interrogatorios" violentos o a abandonar la investigación por falta de opciones. (CA5). ${ }^{\text {iii }}$

Si, conozco algunos policías que se destacaron por el uso de la tortura y todavía son aplaudidos por esta práctica. (C13). ${ }^{\text {iv }}$

Conozco, comisarios, agentes. (A1). ${ }^{\mathrm{xv}}$

Conozco a comisarios, agentes, inspectores que aplican realmente la tortura. Entonces el tipo confiesa que mató hasta a Jesucristo. (A4). ${ }^{\text {xi }}$

Conozco, agentes, comisarios, policías militares. (A2). ${ }^{\mathrm{x} v i i}$

Los conozco. Algunos de mis policías. Los mejores, como dije antes, son los que practican la tortura. En principio rechacé la idea, pero ellos me convencieron de que solo actuando así, fluían las investigaciones. $(\mathrm{C} 12){ }^{\mathrm{xviii}}$

Esa "trivialización" de la tortura permite que los policías vean la práctica de un delito como algo normal de la actividad policial. Además, eso sirve para facilitar 


\section{Dimensiones histórico-sociológicas de la tortura en comisarías de Brasil: el caso Pernambuco}

el ingreso de nuevos policías en esa práctica y refuerza la impunidad para los que ya la practican.

Preguntados sobre si habían presenciado la tortura alguna vez, once policías, de un total de trece entrevistados que contestaron la pregunta dijeron que sí:

Ya. Yo entré en el cuerpo de policía hace ya un tiempo y en las prácticas entré en una comisaría especializada, Todavía no estaba destinado, y vi. Incluso sabiendo el policía que había por allí gente que estaba esperando destino en el cuerpo de policía, no tuvo el menor cuidado de pararlo, esconderlo. (...) Lo presencié, trabajé en una comisaría de guardia donde había un tío que zurraba a la gente por todo. Hasta por poner un pie sobre el banco. Por ejemplo, el creía que era algo indebido, feo, entonces él los corregía torturándolos (...) (C1). ${ }^{\text {xix }}$

Sí. Con normalidad teniendo en cuenta la necesidad del resultado esperado. (C2). ${ }^{\mathrm{xx}}$

$\mathrm{Si}$, desde el primer contacto con la práctica policial, era casi un "regalo" que te llevaran a ver o colaborar a una sesión de tortura para aprender a ser un poli duro. La reacción inmediata fue pedir la dimisión. Pero fui inmediatamente tachada de "buenecita" y de "cobarde", y evidentemente de mala policía. No servía para ser policía, al menos no me adecuaba al molde de policía de aquella época. (CA5). ${ }^{\mathrm{xxi}}$

Si ya. Solamente una vez. Fue en una ciudad de la zona rural del estado de Pernambuco donde yo era comisario. Cuando fui a hablar con el oficial de la PM (Policía Militar) de la ciudad, él estaba en la cárcel, y cuando lo encontré, estaba torturando a un preso que habíamos detenido hacía algunos días. (C3). ${ }^{\text {xii }}$

No, nunca lo presencié. No, realmente creo que nunca quise pensar en eso. Pero es así, creo que intentaría impedir que algo así sucediera... y siendo sincero no sé qué pasaría al final, si sería capaz de formalizar aquello para que fuese investigado, no lo sé, dependería de la situación creo, realmente no lo sé. (CA6). ${ }^{\text {xiii }}$ 


\section{Dimensiones histórico-sociológicas de la tortura en comisarías de Brasil: el caso Pernambuco}

No. (C4). ${ }^{\text {xiv }}$

Una vez tuve que impedir una tortura. Los policías no reaccionaron porque soy comisario, pero seguro, que si hubiese sido de su misma categoría funcional no habrían cedido y encima habrían reaccionado violentamente. (C13). ${ }^{\mathrm{xxv}}$

Al principio de la carrera si y rechacé la situación. Hoy en día sé que torturan, no me gusta, pero lo veo necesario en muchos casos. Nunca torturé, solo lo he permitido, Aunque, algunas tortas he dado, pero no surtieron efecto. (C12). ${ }^{\text {xvi }}$

$\mathrm{Si}$, ya. Como llevo relativamente un cierto tempo de policía, entonces yo ya participé, ya la apliqué. Entiendes. Es así, cuando yo no la puse en práctica o participé, estuve allí. (A1). ${ }^{\text {xvii }}$

Ya. Bueno, a priori, mi reacción cuando entré en la Policía Civil... Te da cosa, te llevas aquel susto. ¿Funciona así? ¿Es esa la imagen que yo tengo de la policía para llegar a los resultados? Pero luego viene aquella cosa personal, aquella búsqueda del resultado. Ves que aquello en determinados casos obtuvo resultados satisfactorios. El uso de la fuerza hizo que tú realmente, directamente hicieses justicia. Porque usaste la fuerza para llegar a determinado fin y a través de aquella fuerza realmente llegaste a aquel determinado fin... Entonces a priori era algo que me incomodaba, pero después pasó a formar parte de las funciones. En determinados casos específicos el uso de la fuerza era necesario para llegar a determinado fin. (A2). ${ }^{\text {xviii }}$

Ya, ya lo presencié. Eran muchas palizas. Los amigos les daban electroshock, los ataban a la silla, aquello del saco, "pau-de-arara" (percha de papagayo)... Yo vi de todo porque pasé por comisarías en las que de madrugada era común... (A4). xxix

La violencia era el día a día. Era práctica común en la época, era la manera de hacer el trabajo, era siempre usar la violencia. También se usaba la tortura psicológica, pero la mayoría era física. El método generalmente es el saco porque el saco no suele dejar marcas... (A3). ${ }^{\mathrm{xxx}}$ 


\title{
Dimensiones histórico-sociológicas de la tortura en comisarías de Brasil: el caso Pernambuco
}

\author{
¿Y cuál fue el sentimiento presenciando tales actos? \\ Si lo es, No me ablandé, no quise que parara, no reprendí a quien lo hacía, siendo su \\ inmediato, parte, superior o subordinado. Y a menudo cuando lo presencié esa fue mi \\ reacción. (A1). ${ }^{x x i}$ \\ Incomodidad, pena del ser humano siendo golpeado. (A4). ${ }^{\text {xxii }}$ \\ Cuando se trataba de un crimen por el cual yo pensaba que la persona se lo merecía, entonces \\ yo también lo aceptaba. (A3). ${ }^{\text {xxxiii }}$
}

La práctica de la tortura es vista con tanta naturalidad que los policías que no la practican tienen que esforzarse para disfrazar su incomodo delante de tal violencia. El comportamiento ante la tortura, en general, es de demostrar indiferencia para parecer integrado. Los tres policías que contestaron a esta pregunta mencionaron la palabra "novinho" (novato). Ese es un estereotipo que sirve para decir que la persona no tiene experiencia, aún no sabe como trabajar. El gran deseo de policías incipientes es pasar de esa fase y sentirse un policía de "verdad". Intentar impedir la agresión o convencer los colegas para dejar de torturar es algo que sólo policías más viejos y con bastante experiencia se arriesgan a hacer.

\section{¿Al principio se manifestó en contra?}

En la PM (Policía Militar). En la PM (Policía Militar) sí. Ellos decían: tú no sabes una mierda, no, novato. Tú tienes que aprender novato. Entonces siempre las broncas eran de 


\section{Dimensiones histórico-sociológicas de la tortura en comisarías de Brasil: el caso Pernambuco}

ese tipo, de manera que me sintiese fuera del grupo. Ellos ponían el dedo en la llaga, porque quien es novato no quiere que lo llamen novato. Quieres ser parte del grupo, quieres ser parte importante del grupo, entonces cuando ponían el dedo en la llaga. Ya veo que eres un blandengue, ya veo que eres un flojo, tenías que ser un recluta. Entonces me tocaban el ego, de alguna manera me apartaban, y de cierto modo decirme apóyanos que tú eres del grupo. No sabes nada, tú no estás apto para ser policía. (A1). ${ }^{\text {xxiv }}$

Cuando entré aquí, ya al principio, en el departamento yo era el fuerte y entonces el tío me decía, novato vas a pegar a fulano. Entonces iba y le decía al preso, te voy a pegar despacio y tú gritas mucho. Voy a golpear la mesa, en la pared y tu grita. Y entonces yo decía que no había soltado nada. El director, que ya murió, me dijo una vez, chaval sólo tienes tamaño, fuerza y flojera. Para qué todos esos músculos si no sirven para pegar a nadie. Entonces yo llegaba a casa y decía: voy a dejar la policía, voy a optar por la educación. Pero luego, toda la vida se pagó muy mal en la educación. Y entonces acababa quedándome. (A4). ${ }^{\mathrm{xxv}}$

Como novato yo no podía. (A3). ${ }^{\mathrm{xxxvi}}$

Sobre la participación del comisario, los entrevistados cuentan que hay tres tipos de implicación del mismo en la tortura: los que participan directamente; los que determinan que los agentes "hagan lo que tienen que hacer" y no participan; y los que fingen que no saben cómo los agentes consiguieron la información, aunque eso sea completamente evidente. Aunque sabemos que hay comisarios que no admiten la tortura, incluso entre los entrevistados, nadie se refirió a ellos, incluso C1 que empezó hablando que hay comisarios de todos los tipos, no se refirió a ninguno que no la aceptara de ninguna manera. 


\title{
Dimensiones histórico-sociológicas de la tortura en comisarías de Brasil: el caso Pernambuco
}

\author{
¿Cómo se da la participación del comisario? ¿Él participa directamente o
} no?".

Los hay de todos los tipos. Está aquel que cierra los ojos, tiene un crimen, tiene una investigación entre manos, tiene un sospechoso, el comisario sabe que va a ser torturado y cierra los ojos. Para mí, eso es participar, o sea, él sabe que lo están "haciendo el trabajo" es una expresión muy utilizada, que quiere decir, torturar. Está el otro que no se ensucia las manos y está aquel otro que participa, que son los menos, y que lo hace para demostrar a la tropa que es un tipo que debe ser respetado porque él es capaz de hacer aquello. (C1). ${ }^{x x v v i i}$

La mayoría de las veces da señal tácita de la necesidad del recurso de la tortura o ha sido informado que el método a ser usado era este y espera la información obtenida. (C2). ${ }^{\text {xxxviii }}$

Por mi experiencia, hay policías que están tan acostumbrados en su día a día a hacer aquella práctica, no solo la tortura como otras irregularidades, que sólo sabe trabajar de ese modo. Entonces lo destinen a una unidad donde la práctica del comisario titular, su jefe, no es de esta manera, él busca otro destino porque sabe que no va a tener aquella continuidad y que no le vale... Hay otro, no... Hay otro, no, que a pesar de esta práctica se amolda a la práctica de su jefe, así, él sabe hasta dónde puede llegar con aquel comisario, él sabe que no puede cruzar esa línea. Porque no va a tener apoyo, al contrario, va a ser advertido, si aquella situación se descubre va a ser suspendido y va a responder, porque su jefe va a comunicar lo que ha hecho. (CA6). ${ }^{\text {xxix }}$

Están aquellos que participan directamente para mostrar al equipo que son unos tipos duros. Están aquellos que no tienen valor para hacerlo, pero quieren que los agentes lo hagan. Están aquellos que ni valor para hacerlo ni valor para asumir las consecuencias, entonces fingen que no saben lo que los agentes hacen, para no involucrarse. Si sale mal van a decir que no sabían nada. No sabina lo que el agente quería decir con: "¿puedo sacar el trabajo adelante señor?". (C3). ${ }^{\mathrm{xl}}$

Conozco los tres modos de participación: practicando directamente, mandando que se practique la tortura o simplemente omitiéndolo, desde que el caso se solucione. Tales 


\section{Dimensiones histórico-sociológicas de la tortura en comisarías de Brasil: el caso Pernambuco}

posturas existen inclusive con comisarios que ocupan cargos administrativos de policía. (C4). ${ }^{\text {xli }}$

Depende del perfil del Comisario. Hay perfiles para todos los gustos. En general, lo estimulan, lo apoyan, pero no participan directamente. Muchos no "se ensucian" las manos directamente, pero son permisivos con la práctica y hasta imponen un cierto "límite" para controlar la vigilancia externa. (CA5). ${ }^{\text {xlii }}$

Bueno, ya participé y ya vi varias posturas. Estaba aquel que lo ignoraba y decía yo no estoy viendo nada, pero también si estalla la culpa es tuya... También vi aquel otro que no participaba efectivamente, pero tampoco lo prohibía, era consciente de ello. Que para mí era el peor. De las especies para mí era el peor. Porque también estaba aquel que era efectivo, era él el que decía: mira el primer golpe es mío y lo que pase yo cargo con ellos. Como sucedió en algunas situaciones y él aguantó, Sucedió en algunos casos... Y de gran proporción, y él fue macho y aguantó. Como hay otros que sólo quieren los laureles. Él les mete en la cabeza a los policías que está en contra, pero que los policías pueden hacerlo en busca de un resultado digno para él el comisario, pero el día que estalle la bomba, él el comisario, va a decir que no lo sabe, porque no tiene ninguna orden por escrito. Y el policía, es lo de siempre, solo cae quien es el torturador, el mentor nunca cae. (A1). ${ }^{\text {xliii }}$

Realmente la participación del comisario es la omisión. Es algo así, voy a soltar a mis mejores perros de caza a la búsqueda de determinada presa, para llegar a determinada finalidad. Y lo que les voy a dar es carta blanca para que ellos trabajen. No voy a participar, no voy meter mano en aquello, pero yo sé lo que están haciendo. Yo sé que para llegar a ese resultado estoy dando indirectamente apoyo total. Pero yo no vi a ningún comisario que usase él mismo la fuerza. (A2). ${ }^{\text {xliv }}$

Hay unos que van. Hay unos que fingen que no lo ven, lo saben todo, pero en el momento de caer dicen que no saben nada, que no vieron nada. Lo dicen, si pasa eso yo allí no estaba. Háganlo, si sale bien, pero si no sale bien, que cada uno responda por sus actos. (A4). ${ }^{\text {xlv }}$ 


\section{Dimensiones histórico-sociológicas de la tortura en comisarías de Brasil: el caso Pernambuco}

Algunos participaban directamente y otros no querían saber de qué manera sucedía. Querían el resultado. (A3). ${ }^{\text {xlvi }}$

Lo mismo pasó cuando hicimos igual pregunta a los agentes de policía. La pregunta de si hubo algún comisario que no aceptara de ninguna manera la práctica de la tortura, tuvo dos contestaciones contrarias: el entrevistado más nuevo conocía a varios comisarios que no aceptaban la tortura; el entrevistado que estaba casi jubilado no conocía a ninguno.

¿Hubo alguno que no aceptara?

Que yo recorde, no. (A3). ${ }^{\text {xlvii }}$

Ya, principalmente hoy en día, en la realidad de la Policía Civil, es mucho más común encontrarte comisarios que valoran la investigación, inteligencia, que el uso de la fuerza. Hace nada que he trabajado con un comisario que era, justamente, totalmente lo contrario. Era exmilitar, recién salido de la academia, entonces decía: "policía es golpe, tiro y partir la cara. Es lo que los delincuentes se merecen". Él mismo era el líder del equipo y por eso el equipo estaba influenciado por él. Durante algunos meses el equipo funcionó, pero trabajando en ese esquema. Funciono y prosiguió durante algún tiempo. Hasta que el equipo fue desmembrado por otros motivos administrativos, no relacionados con la tortura. $\mathrm{La}$ filosofía de este comisario era trabajar con el uso de la fuerza. (A2). ${ }^{x l v i i i}$ 


\title{
Dimensiones histórico-sociológicas de la tortura en comisarías de Brasil: el caso Pernambuco
}

\author{
¿Y después, cómo actuaba cuando su equipo le practicaba?
}

\begin{abstract}
Varias veces. Así es, varios momentos yo me manifesté en contra. Decía, 'Eh, se acabó, no va a pasar más', porque yo veía que estaba tomando una proporción en la que el propio torturador ya no tenía control. Es cuando se vuelve peligroso. (A1) ${ }^{\mathrm{xlix}}$
\end{abstract}

Lo que yo podía hacer para aliviar aquella tortura lo hacía... por ejemplo, no apretaba mucho, le preguntaba si quería agua, aquello de decir, chaval infelizmente el sistema es así, por qué no colaboras... Ya hasta discutí con un colega porque el tío ya había abierto el juego y mi colega fue a golpearle y le dije que para qué si ya había colaborado. Entonces se creó ese malestar entre mi colega y yo inclusive no nos hablamos hasta hoy... Generalmente íbamos a las 3 o las 5 de la mañana a buscar delincuente, entonces era importante estar a bien con los colegas porque si no algo podía salir mal... Entonces a mí no me gustaba ver a los colegas echando puertas abajo, arrastrando gente, pero intentaba juntarme con otros colegas que pensaban parecido a mí y nosotros intentábamos calmar a los más violentos. (A4). ${ }^{1}$

Cuando se trataba de un crimen que yo pensaba que la persona lo merecía, entonces yo también aceptaba. (A3). ${ }^{\text {li }}$

Cuando los entrevistados fueron preguntados sobre la percepción que tenían de la práctica de la tortura en la policía en el momento en que ingresaron en ella, todos tenían la percepción que la mayoría de los comisarios la practicaban o la aceptaban. Algunos han mencionado que ha disminuido mucho, pero también hubo quien dijo que los policías novatos (novinhos) también la practicaban a menudo.

Y cuando usted entró en la policía, ¿observaba que había más o menos comisarios que la practicaban? 


\section{Dimensiones histórico-sociológicas de la tortura en comisarías de Brasil: el caso Pernambuco}

Todos o la gran mayoría. Cuando entré era la cultura general que prevalecía, era la de la violencia. Claro que había excepciones, pero eran minoría casi no identificada. Los llamados “intelectualizados" estaban siempre en el ostracismo, también tenían miedo a que confesaran y pagaran por eso y no pudieran gozar de los privilegios que ofrece el poder. (CA5). ${ }^{\text {lii }}$

La gran mayoría la practicaba $(\mathrm{C} 1){ }^{\text {liii }}$

Los que la toleraban alcanzan el setenta por ciento, intentando demostrar que no sabían que eso ocurría transfiriendo la responsabilidad para el equipo policial. (C2). ${ }^{\text {liv }}$

Más de la mitad de ellos (la practicaban). (C4). ${ }^{\text {lv }}$

Yo conozco a comisarios que la practican directamente y hay algunos que utilizan al policía subordinado para hacerlo, pero están informados. (CA6). ${ }^{\text {lvi }}$

Yo creo que la minoría tortura. No lo sé. Ahora estaba pensando en mis colegas más próximos y la mayoría no tortura, ni admiten que sus policías torturen. Pero cuando pienso en otros grupos dentro de la policía, creo que esa relación se invierte. Conozco grupos de comisarios en que la excepción son los que no la practican. (C3). ${ }^{\text {lvii }}$

La proporción era enorme, no tengo ni idea, no obstante, yo no lo hacía, por eso no tenía nada de éxito en el área. (C12). ${ }^{\text {lvii }}$

Más de la mitad de los que trabajaban en el área operacional. (C13). ${ }^{\text {lix }}$

La imagen que se nos vende es que es el veterano el que es torturador, el novato no es torturador. ¡Son los legalistas, al extremo! El agente entra con esa idea y hasta nuestra predisposición para trabajar con los novatos porque nosotros no queremos bronca, esa es la palabra, porque el agente está todavía a prueba y el agente no busca bronca, aunque la verdad eso es medio leyenda porque existe mucho veterano legalista y mucho novato que no tiene freno. Creo que vio mucho "Tropa de Elite” y todavía está acelerado. (A1). ${ }^{\mathrm{lx}}$ 


\section{Dimensiones histórico-sociológicas de la tortura en comisarías de Brasil: el caso Pernambuco}

Hoy se practica menos que antes. Si coges una época ahí por los años 80, de la dictadura. El propio asunto de los derechos humanos está más a la vista hoy que antes... Hoy el policía tiene esa consciencia de que si lo pillan lo van a penalizar. (A2). ${ }^{\text {lxi }}$

Hoy ha mejorado mucho, de 30 años para acá. A causa de los estudios, los comisarios tienen mejor cabeza. Cuando entré era más del $50 \%$ y hoy un $10 \%$... A veces quieres respetar a la persona. Pero hay delincuentes que no quieren respetar a nadie. No respeta a su padre, no respeta a su madre, no respeta parientes, no respeta a nadie. Entonces tienen que respetar a alguien. Y ese alguien tiene que ser la policía. Entonces nosotros hacemos eso... (A4). ${ }^{\text {lxii }}$

La percepción es la de que la casi totalidad de torturadores son hombres. Una de las razones puede ser el bajo número de mujeres en la actividad investigadora ${ }^{172}$. Como hablamos de una corporación "machista" en un Continente donde predomina el machismo y en una región de Brasil también conocida por su alto machismo, es fácil imaginar que las mujeres, en general, son puestas en actividades administrativas, menos duras. También cuando tratamos de la percepción o presunta eficiencia de la tortura, a veces, el único discurso contrario era el de las mujeres.

¿Quién practica más, hombres o mujeres?

(...) las mujeres torturan menos, es un hecho, Aunque hay torturadoras mujeres y en muchas ocasiones aquellos hombres que no se adherían a la tortura eran considerados muy ('), extremamente tímidos en su vida social y no se adherían hasta por falta de carácter, digámoslo así, no eran operacionales. El operacional en un determinado tiempo en la policía significaba también aquella persona disponible para usar la tortura. (C1). lxiii $^{\text {. }}$

$172 \quad$ "Hoje é possível encontrar mulheres em diferentes atividades, desde o comando até o operacional. No entanto, a maior parte delas continua atuando em postos administrativos, mais identificados com o feminino". (CARTA CAPITAL, 2013). 


\section{Dimensiones histórico-sociológicas de la tortura en comisarías de Brasil: el caso Pernambuco}

Seguro hombres. Creo que la fuerza masculina impone. Primero que la mujer es más sensible a ver sangre, las lesiones, ese tipo de cosas, en mi opinión. El hombre por su fuerza física cree, está hasta el refrán que dice: "Palos que no resuelven es que fueron pocos palos" ( $p a u$ que não resolve é quando o pau é pouco). Entonces piensa que mientras él no diga nada ha de ir intensificando la práctica de la tortura porque él cree que fueron pocos palos. . (C14). lxiv $^{\text {. }}$

Los hombres. La hormona de la testosterona dice mucho. Son pocas las mujeres que lo hacen, sin embargo existen muchas que lo permiten. (C12). ${ }^{\text {xv }}$

Los hombres, pues los métodos con frecuencia exigen fuerza física. Pero muchas mujeres lo toleran o incentivan. (C13). ${ }^{\text {lxvi }}$

No hay acuerdo en torno a la pregunta de si, para resolver ciertos casos específicos, la tortura sería imprescindible. Cuando preguntamos si hay algún tipo de delito en que es necesaria la práctica de la tortura, seis dijeron que no había justificación; cuatro justificaran con el combate a los traficantes de drogas; tres, para salvar una vida; dos, para solucionar crímenes contra el patrimonio.

¿Crees que para algunos tipos de crímenes o criminales puede ser necesaria, en algunas situaciones, la práctica de la tortura? Si es que sí ¿para qué tipos?”

Sí. En caso de terrorismo y crimen organizado, en los casos de cuadros criminales más violentos. (C2). ${ }^{\text {lxvii }}$

No es posible asociar la tortura a determinado tipo penal, pero en algunos como extorsión mediante secuestro, robo a banco y camión acorazado su utilización es más común. Los policías que utilizan esa práctica dicen que esos criminales son más brutos y no conocen otro idioma. (C13). ${ }^{1 \text { viii }}$ 


\section{Dimensiones histórico-sociológicas de la tortura en comisarías de Brasil: el caso Pernambuco}

En algunos tipos de tráfico para probar la materialidad y no existiendo interceptación, sí. Muchos traficantes no van a confesar solamente en la conversación para confesar donde está la droga. (C12). ${ }^{\text {lxix }}$

Sí. Estupefacientes por ejemplo. (A1). ${ }^{\mathrm{lxx}}$

No vislumbro esta hipótesis. (C4). ${ }^{\text {Ixi }}$

No. Nunca. (CA5). ${ }^{1 \times x i i}$

En verdad entiendo, De cara a la realidad de las condiciones, que los crímenes contra el patrimonio muestran una cierta necesidad de violencia en el trato con los criminales, y traen con ellos mismos un cierto código de honor, y la presión por el resultado inmediato en los crímenes de esta naturaleza apuntan a métodos de este tipo. (C2). ${ }^{\text {Ixxiii }}$

Digámoslo así, que si la vida de una tercera persona estuviese en riesgo. Un secuestrador que mantiene la vida de la persona que va a morir, pero eso se trata de una cosa puntual que el tío va a tener que solucionar solo. La institución no puede defender la conducta. Tiene que cambiar la ley, porque muchas veces la gente confunde la tortura en el día a día en la cárcel, en el sistema penitenciario, en las comisarías, con la tortura terrorista, suena a asunto muy complicado. (C1). ${ }^{\text {lxiv }}$

Para salvar una vida. En legítima defensa o estado de necesidad. (C3). ${ }^{1 \times x v}$

No. llevo 11 años como policía y nunca trabaje usando esa práctica... (CA6).). ${ }^{\text {Ixxvi }}$

La tortura es utilizada para obtener confesiones sobre la práctica de un crimen o para penalizar a la persona de la cual se tiene seguridad que practicó un crimen. No vislumbro, en ambas hipótesis, un tipo penal que justifique tal práctica. (C4). ${ }^{1 \times x v i i}$ 


\section{Dimensiones histórico-sociológicas de la tortura en comisarías de Brasil: el caso Pernambuco}

No, para mi ningún crimen es admisible que sea investigado a través de la tortura. (CA5). ${ }^{\text {lxxviii }}$

Hoy en día ya no, sin embargo, cuando hay denuncia de tráfico e incautas solo una piedra, la mayoría de las veces el sospechoso entrega el restante de la droga a través de la tortura, no lo dudo. En caso contrario, respondería como usuario y volvería a traficar, perjudicando a muchas familias. $(\mathrm{C} 12){ }^{\text {lxxix }}$

No. $(\mathrm{C} 13){ }^{\operatorname{lxxx}}$

Sí. Estupefacientes por ejemplo. (A1). ${ }^{\text {lxxxi }}$

Hay una frase que oí que dijo un policía, también tiene miedo, tiene hijos. Entonces va para un caso en el que fue violada una chica de la edad de su hija... el policía no consigue separar, él se involucra en el caso emocionalmente... es como un desahogo para el policía, pues el tipo comete un crimen bárbaro y sólo va a pasar 5 o 4 años y lo van a soltar. El policía no acepta eso... Entonces él realmente se mete en actos de violencia, no sólo para llegar al resultado. (A2). ${ }^{\text {lxxxii }}$

Algunos tipos de crímenes: Creo... Elementos que merecen ser torturados porque ellos hoy se aprovechan, y la ley los favorece, y dejan que llegues hasta el último recurso para si tú tienes inteligencia y material de trabajo ahí lo vas a descubrir, si no, él se va a quedar callado hasta la conclusión del interrogatorio, de la investigación. Si no se consigue probar va a ser favorecido. Y hay personas que sólo funcionan a palos, es de la índole de la persona. No confiesa, de ninguna manera, sólo confiesa si se lleva unos palos. Pero desafortunadamente, o afortunadamente hoy en día ya no se práctica. (A3). ${ }^{\text {lxxiii }}$

No. Creo que no. (A4). ${ }^{\text {lxxxiv }}$ 


\section{Dimensiones histórico-sociológicas de la tortura en comisarías de Brasil: el caso Pernambuco}

Los entrevistados no tenían claro dónde se practica más la tortura, si es en la Capital o en el interior. Por un lado es más fácil que haya tortura en las comisarías donde hay más presión por resultados, es decir, en las comisarías de la Capital, de las grandes ciudades y comisarías especializadas. Por otro lado en el interior hay menos control y fiscalización y así es más fácil torturar.

¿Dónde se practica más la tortura, en la Capital o en el interior?

En la Capital. Debido a la demanda y a la presión. (C2). ${ }^{\text {lxxxv }}$

Creo que en las ciudades más pequeñas. Por estar más distantes de los órganos supervisores. (C4). ${ }^{\text {lxxxvi }}$

No sé contabilizar si uno es mayor que el otro, pero yo sé que hay en los dos, en la Capital y en las ciudades del interior del Estado. (CA6)). . $^{\text {xxxvii }}$

En la PC (Policía Civil) es difícil decir eso, no hay como hacerse una idea. Yo creo que en las ciudades del interior del Estado se practica más... ahora, es muy difícil decir eso. (C1). ${ }^{\text {lxxxviii }}$

No sé decirte. Tengo la impresión que en las comisarías especializadas (están en la Capital) se practica más. Pero es sólo una intuición. (C3). ${ }^{\text {lxxix }}$

Se práctica donde hay menos control y donde la sociedad tiene menos acceso. (CA5). ${ }^{\mathrm{xc}}$

En la capital, donde están las comisarías especializadas que están preocupadas por presentar resultados. $(\mathrm{C} 13){ }^{\mathrm{xci}}$ 


\section{Dimensiones histórico-sociológicas de la tortura en comisarías de Brasil: el caso Pernambuco}

En la región metropolitana, donde vive la mayor parte de la población pobre. Pero digo eso no por ser pobre y si por no poder contar con un abogado que lo defienda, como a los ricos. $(\mathrm{C} 12){ }^{\mathrm{xcii}}$

En las ciudades del interior, en el "sertão". Donde la policía tiene los ojos tapados hacia esto. Porque además de no existir inspección como existe en la capital, porque en la capital está la magistratura, hay cámaras por todos lados, hay gente mejor formada, y en la zona rural, ¿Que hay allí? En la zona rural hay un tipo que probablemente no llego ni a secundaria, casi no sabe ni firmar, que no sabe nada de derechos humanos, que para él llevarse un golpe de un policía, forma parte del trabajo policial. Tú llegas a Recife, el delincuente, por muy “desgraciado" (pé-rapado) que sea tiene cierta noción del asunto "Yo soy un criminal pero tú no me puedes tocar, tengo derechos humanos, tengo abogado". En la zona rural, el criminal no tiene esa idea, entonces para él llevarse un palo de la policía es más que correcto, es el trabajo de la policía... (A2). ${ }^{\text {xiii }}$

En la capital, porque la violencia es mayor en la capital. (A4). ${ }^{\text {xciv }}$

Capital, porque hay un volumen mayor de trabajo. (A3). ${ }^{\mathrm{xcv}}$

Aunque esté ubicada en esta parte del trabajo, en las entrevistas dejamos el final para preguntar al entrevistado si él ya había torturado. De diez entrevistados que han contestado la pregunta, nueve, ya habían torturado.
¿Ya practicó?
Sí. (C2) ${ }^{\mathrm{xcvi}}$
Sí. (C1). ${ }^{\text {xvii }}$ 


\section{Dimensiones histórico-sociológicas de la tortura en comisarías de Brasil: el caso Pernambuco}

Yo mismo no. Algunos bofetazos en las espaldas y en la cara, sí, pero nada que machacase el investigado. (C12). ${ }^{\mathrm{xcviii}}$

No. $(\mathrm{C} 13){ }^{\mathrm{xcix}}$

Ya, infelizmente sí. (A4). ${ }^{\mathrm{c}}$

Sí. Algunas veces. No solía ocurrir tanto como cuando era PM. (A2). ${ }^{\text {ci }}$

Practicaba, algunas veces sí. (A3). ${ }^{\text {iii }}$

Sólo cuando era necesario para la investigación. (C15). ${ }^{\text {iii }}$

Ya. (A1). ${ }^{\text {civ }}$

Algunos admiten seguir torturando, otros dicen que pararon, pero pueden volver a practicar...

Há alguma situação em que você se sentiria tentado a voltar a praticar?

Casos de violación a niños o ancianos. Hacer barbaridades. Realmente yo tengo terror a ese tipo de gente. Entonces en esos casos yo busco a quien acercarme para no perder el control (A4). ${ }^{\mathrm{cv}}$

¿Qué pasó para que parase de torturar?

Todavía no paré, pero repito, la violencia que yo practico es muy suave. No practico "saco", electroshock y si tortas, sin embargo, permito lo primero con restricciones. (C12). ${ }^{\mathrm{cvi}}$ 


\section{Dimensiones histórico-sociológicas de la tortura en comisarías de Brasil: el caso Pernambuco}

(C2 no quiso contestar esa pregunta). ${ }^{\text {cvii }}$

Como dije anteriormente, ves que no vale la pena el resultado al que has llegado. Por mejor que haya sido, por más satisfactorio el trabajo profesional, pero, ¿y tú moral? ¿Y tu bien estar? Colocar la cabeza en la almohada y dormir... Entonces cuando se llega a ese punto, ¿Ha valido la pena?... Entonces vas a tener que cambiar los medios... ¿Será que existe una forma más inteligente de llegar al resultado? (A2). ${ }^{\text {cviii }}$

\section{¿Usted encontró esa forma más inteligente?}

Hoy ya lo encuentro, pero no existen los medios, los aparatos, ni el apoyo necesario... Uno lo intenta, pero la policía no te lo da ... Entonces uno tiende a evitar llegar a aquel camino, pero es extremamente difícil porque el reproche permanece la propia, policía no quiere saber que has cambiado de mentalidad. No quieren saber de teoría, ni de filosofía. quieren saber que tú no estás durmiendo. Quieren resultados. El reproche continúa y tú te encuentras en aquel túnel sin salida. Entonces es cuando pasa lo que está pasando con buena parte de los policías. Ellos entran, no están de acuerdo, y se largan... Tú no vas cambiar el sistema, ¿el sistema de la Policía Civil? No, no lo vas a cambiar. Entonces la única solución es que te largues. (A2). ${ }^{\text {cix }}$

Usted ha dicho que pretendía jubilarse en la policía ¿y las noches de sueños?

El resultado va a tener que llegar. De una forma, o de otra. Yo entiendo ahora que va a ser de una forma gradual. No puedes cambiar radicalmente. Entonces, al principio vas a tener que ser maleable... Yo pretendo cambiar, pero sé que no va a ser fácil, ni se puede decir: yo no practico eso nunca más, de ninguna manera. Yo no soy tan radical. Y admito que en determinados casos pueda ser que use ese recurso. (A2). ${ }^{\mathrm{cx}}$ 


\section{Dimensiones histórico-sociológicas de la tortura en comisarías de Brasil: el caso Pernambuco}

Cuando buscamos las razones para parar de torturar percibimos que la organización no ejerce ninguna presión. C1 alegó que tal práctica estaba afectando a sus relaciones personales.

La conciencia. (A4). ${ }^{\text {cxi }}$

Yo creo que debe haber sido madurez para saber que, lo primero, que todo tiene una consecuencia, para el propio torturador. (C1). ${ }^{\text {cxii }}$

Yo creo que son las consecuencias del acto. (C1). ${ }^{\text {cxiii }}$

Llama la atención el caso de $\mathrm{C} 1$, pues cuando había ingresado en la policía y era agente de policía jamás había torturado y estaba en contra de la práctica de la tortura. Sin embargo, cuando hizo una oposición para comisario pasó a torturar, pues sentía el peso de la presión para obtener resultados. Ahora él no era ya uno más del equipo, él era el responsable por el equipo. También podemos mirar por el foco de la autoridad.

C3 también atribuye a sus relaciones personales el cambio de idea frente a la tortura.

Yo nunca torturé. Pero antes me hubiese gustado tener un agente que pudiera torturar, aunque nunca lo haya encontrado en todas las comisarías en las que he trabajado. Ni nunca tuve valor para pedírselo, ni al contrario, ellos pedirme autorización para torturar. Yo echaba de menos no disponer de ese recurso. Tener una reserva estratégica para los casos más complicados... Hoy, no. Hoy ya no quiero esa facilidad. ¿Que qué ha pasado? No lo sé...Quizá he madurado... No lo sé... Tal vez la preocupación por los resultados también haya disminuido... Tal vez la aproximación con algunos grupos más legalistas que me rechazarían si hubieran sabido que yo era tolerante con eso... Realmente, no lo sé. (C3). ${ }^{\text {cxiv }}$ 


\section{Dimensiones histórico-sociológicas de la tortura en comisarías de Brasil: el caso Pernambuco}

Hemos visto algunos casos de cambio de posicionamiento ante la tortura. La policía facilita la absorción de valores violentos pero no facilita la pérdida de tales valores. Cuando ocurre que un policía deja de torturar, en general, lo hace por presión de sus relaciones personales.

Llama la atención la referencia frecuente a la búsqueda de resultados. Podemos decir que "resultados" es una de las palabras más usadas por los entrevistados...

¿Y la anterior preocupación con los resultados?

Continua. Pero con más pudor. Quiero los resultados, pero no a cualquier precio. $(\mathrm{C} 3){ }^{\mathrm{cxv}}$

Continua igual, aunque sin las preocupaciones del reconocimiento institucional, y si con un resultado práctico frente a la sociedad. (C2). ${ }^{\text {cxvi }}$

Se buscan resultados, no importan los medios. Como ya dije antes, sí. (C12). ${ }^{\text {cxvii }}$

Primero intenté obtenerlo a través de la red de informantes y después con modernas técnicas de investigación, como la interceptación telefónica. $(\mathrm{C} 13) .{ }^{\text {cxviii }}$

A medida que el tiempo va pasando vas alcanzando una madurez y si inicialmente estabas preocupado con lo que pensaban de ti, como la institución iba a acogerte, con el paso del tiempo pasas a preocuparte con los propios valores. La institución pasa a estar en un segundo plano. Y vas entendiendo que el día que seas ineficaz vas a ser substituido. (A1). ${ }^{\text {cxix }}$

¿Cómo el torturador lidia con tales actos? 


\section{Dimensiones histórico-sociológicas de la tortura en comisarías de Brasil: el caso Pernambuco}

En principio yo pienso así, que el día a día, en su cabeza se mete que sólo lo va a conseguir, de aquella manera. Y es como si el tío, hasta por estar obstinado en aquella práctica, hasta ya está acostumbrado, sabiendo que tipo la policía va pillar, va a pasar por aquello. Y en aquel momento, en aquella investigación esto no le molesta, pero va a llegar un momento en la vida del policía que aquello va a molestarle. Es como si eso se quedase guardado, llega un momento en el que aquello va a estallar de algún modo. O que él se va a volver loco o se va a transformar... En aquel momento específicamente, en mi opinión eso no le molesta, no le incomoda porque piensa que aquello es normal en la investigación. (CA6). ${ }^{\text {cxx }}$

Mientras salga bien, tortura con la misma naturalidad que realiza una citación o registra una denuncia. El problema está cuando sale mal (la víctima denuncia, o muere...). Entonces empieza a darse cuenta que estaba solo en eso. Todos se rajan y él se transforma en un monstruo de la noche al día. (...). Como va a lidiar con eso en el futuro no tengo la más mínima idea. Sólo sé que los que practican la tortura hoy no son en nada diferentes de los que no la practican. Son buenos padres, cariñosos con las compañeras, religiosos. Creo que algunos no se dan cuenta de la locura que practican y piensan que están haciendo un trabajo normal. (C3). ${ }^{\text {cxi }}$

(...)Yo ya vi esta frase, no recuerdo donde. "Antes de nada la tortura deshumaniza al torturador". Antes inclusive que a la víctima, porque la victima está allí sufriendo una injusticia, es víctima de un crimen, no es por opción, mientras el torturador está en su profesión. Yo pienso que la tortura como en cualquier otro crimen, la practica reincidente de cualquier crimen afecta al equilibrio emocional, a la salud mental de las personas. Un hombre que está habituado al mundo del crimen está perturbado. (C1). ${ }^{\text {cxxii }}$

Ellos también hablan de la presión para presentar resultados rápidos ${ }^{173} \ldots$

173 "O fato de, mesmo nas democracias, a atividade policial conter pressões inerentes no sentido do desrespeito à lei indica que as atrocidades dos policiais brasileiros podem fazer parte de um 'continuum' organizacional de violência policial. Poderia afirmar-se que, nas democracias em situações padronizadas de ação policial, mais que em emergências especializadas, a violência policial brota das pressões associadas a uma 'personalização de trabalho' 'normal' do policial. Esse ponto de vista do policial cria a suspeita que pode promover a violência e isola a atividade policial 


\section{Dimensiones histórico-sociológicas de la tortura en comisarías de Brasil: el caso Pernambuco}

¿El comisario sufre una presión ${ }^{174}$ más grande para obtener resultados ${ }^{175}$ ? ¿Pasa a tener una evidencia más grande en la Institución?

Pasa, porque dentro de un contexto, no es uno más, es el responsable de todo un sector que va a ser responsable de investigar una gama de crímenes, cuya ineficiencia va a recaer sobre sus hombros. (C1). ${ }^{\text {cxxiii }}$

Claro. Él es el jefe del equipo. Toda la carga recae sobre él. (C3). ${ }^{\text {cxxiv }}$

\subsubsection{Presunta eficiencia del método}

Descubrir cómo se ha producido un delito, revelar detalles que el autor intenta esconder de todas las maneras no es tarea fácil. Si además de eso hay muchos más delitos que personas para investigarlos, si no hay medios suficientes para resolverlos,

de alguns dos controles sociais externos que podem regular o comportamento dos policiais". (HUGGINS, 1986: 349).

174 Cuando hay el encuentro de la autoridad con el sospechoso y la presión por eficiencia el resultado probable es que el policía busque el camino contrário a la ley, pues la demanda de resultados crea una práctica policial donde la preocupación con las leyes es mínima. (SKOLNICK, 1966).

175 A pressão pública sobre os policiais para resolver crimes rapidamente e a custos mais baixos possíveis resulta em que os delegados têm de cortar caminho e permitir que seus policiais sejam "não profissionais". Assim, em vez de "fazer uma operação contra um só homem (que pode exigir) cinco homens para (o) capturar e interrogar", um delegado pressionado permitirá que seus homens empreguem duas horas de tortura e obtenham o que necessita. (HUGGINS, 2006: 202). 


\section{Dimensiones histórico-sociológicas de la tortura en comisarías de Brasil: el caso Pernambuco}

la tortura puede ser un medio tentador. Incluso quien no práctica la tortura admite, en Brasil, su funcionalidad.

¿Por qué usar la tortura?”

Yo ya oí comentarios de alguien que usa esa práctica, que decía, atracador de banco, ladrón, sólo habla si le pegan. (CA6). ${ }^{\text {cxxv }}$

Un cierto reconocimiento de eficiencia. (C2). cxxvi $^{\text {. }}$

En los casos que conozco el policía siente placer en practicar la tortura y/o obtener los resultados esperados, creyendo ser su deber, y hasta como forma de proteger a la sociedad contra aquel criminal. (C4). ${ }^{\text {cxxvii }}$

Resultado fácil. Resultado implica promoción, elogio, reconocimiento profesional y social. $\mathrm{Y}$, si es deshonesto, dinero. (C3). cxxviii $^{\text {. }}$

En primer lugar la satisfacción personal de un enfermo mental. Obviamente un torturador no es una persona que goza de sus facultades mentales normales. Segundo porque atiende también al interés de otros enfermos como él. (CA5). ${ }^{\text {cxix }}$

No hay duda de que casi todos los entrevistados creen que la tortura es "eficiente". El tema de la "eficiencia" está presente en nueve, de diez, discursos.

¿Cree que los buenos resultados favorecen la permanencia de la tortura en las comisarías?" 


\section{Dimensiones histórico-sociológicas de la tortura en comisarías de Brasil: el caso Pernambuco}

Sí. En estos casos la tortura es asumida como un "método" que funciona. (C4). ${ }^{\text {cxxx }}$

Sí. Se acumulan la ausencia de metodología y la ineficaz represión. (C2). ${ }^{\text {cxxxi }}$

Nadie se arriesgaría a practicarla si no diese buenos resultados. Sólo los locos o los sádicos, pero esos son la excepción. (C3). ${ }^{\text {cxxxii }}$

No creo que haya buenos resultados en las comisarías. La policía es muy poco eficiente y seguramente la tortura contribuye a esa ineficacia. Casos de buenos resultados sin uso de la tortura son la excepción y no la regla general. Hoy en día, los policías que no torturan no "trabajan", es eso lo que se oye y lo que se ve. La actual dirección tiene todo un discurso progresista, pero no consigue sensibilizar ni tampoco controlar al gran efectivo de los policías. No tienen alternativas. (CA5). ${ }^{\text {cxxxiii }}$

Puede ser. Puede ser. (CA6). ${ }^{\text {cxxxiv }}$

El resultado es siempre usado como justificación. Una forma de disminuir (la tortura) es proporcionar otras formas de investigación y capacitar a los policías para utilizar técnicas modernas de investigación. $(\mathrm{C} 13){ }^{\mathrm{cxxxv}}$

Sí. Desgraciadamente la verdad tiene que ser dicha. Si no quieres practicar la tortura, vete a trabajar en una especializada tipo, consumidor, estafa, turista... en las otras en que los crímenes son más graves, estoy seguro de que "se reparte leña” (o pau canta). (C12). ${ }^{\text {cxxxvi }}$

Exactamente, porque no se puede dejar de decir que existe una cierta eficiencia. Si no tuviera resultado, naturalmente acabaría por ser un medio obsoleto. Pero como hay eficacia con el uso de esa metodología aún sobrevive. (A1). ${ }^{\text {cxxxvii }}$

Yo creo que la tortura tiene una gran participación en los buenos resultados. Aunque no en la mayoría. (A2). ${ }^{\text {cxxxviii }}$

Infelizmente sí. (A4). ${ }^{\text {cxxxix }}$ 


\section{Dimensiones histórico-sociológicas de la tortura en comisarías de Brasil: el caso Pernambuco}

Cuando analizamos algunos fragmentos de las entrevistas abajo vemos que prácticamente todos los policías entrevistados consideran la tortura como un medio eficiente de investigación y tienen la creencia de que si desaparece la tortura habrá una disminución en la resolución de delitos, principalmente, por la falta de preparación y estructura de trabajo actual.

“Crees que sin el uso de la tortura la resolución de delitos sería menor?”

Creo que si hoy se acabase de una vez con la tortura habría un aumento significativo de casos no investigados, porque muchos no saben trabajar de otra forma. Son necesarias dos acciones paralelas: enseñar a investigar y reprimir la tortura. (C3). ${ }^{\text {cxl }}$

En mi institución, sí. Porque no existe preparación profesional ni material para poder obtener las pruebas necesarias de la materialidad y de la autoría. (C4). ${ }^{\text {xli }}$

Sí. Debido a la falta de medios que posibiliten una investigación serena y legal. (C2). ${ }^{\text {cxlii }}$

Realmente yo no sé, si yo no la usara, si la resolución de los crímenes sería inferior, realmente no lo sé... (CA6). ${ }^{\text {cxliii }}$

No. Porque pienso que la conclusión de los crímenes tendría un mejor resultado si la policía fuera dotada de nuevos, mejores y más adecuados métodos de investigación y evidentemente si los policías supieran cuál es su real misión dentro de la policía. (CA5). ${ }^{\text {cxliv }}$

Lógicamente que sí. Digo y repito. Sin métodos modernos como la interceptación (es difícil conseguir pruebas para la petición) y otros, no hay como llegar al autor del crimen a no ser torturando, aunque sea psicológicamente. $(\mathrm{C} 12) .{ }^{\text {cxlv }}$ 


\section{Dimensiones histórico-sociológicas de la tortura en comisarías de Brasil: el caso Pernambuco}

No. Incluso porque en los últimos años cayó drásticamente la práctica de la tortura y aumentó la resolución de crímenes. $(\mathrm{C} 13){ }^{\text {cxlvi }}$

En la capital no caería tanto, pero en la zona rural profunda (sertão), donde sólo hay un comisario con la mano larga para hacerlo todo, allí sí caería drásticamente. Caería drásticamente. (A1). ${ }^{\text {cxlvii }}$

Las "caritas" iban a estar todas en rojo (índice de resolución de crímenes: rojo, por debajo de las metas establecidas). Principalmente en la zona rural. (A2). ${ }^{\text {cxlviii }}$

Sí, porque tiene que haber otro método para sustituir a aquel. Un método inteligente para sustituir a la tortura. (A4). ${ }^{\text {cxlix }}$

Creo, yo creo que si se torturase se descubrirían más cosas, yo creo. Que en realidad la palabra correcta, que era muy usada en la época, no es tortura, sino "hacer el trabajo" (tirar serviço). Esa palabra, tortura, nunca es usada. Esa palabra, tortura, viene de la época de la dictadura... Entonces, esa palabra, tortura, es muy usada por (los de los) derechos humanos. Ellos la usan mucho. Pero la propia policía no, desde que yo estoy dentro, nadie nunca la usó. Tortura a fulano, vamos a torturarlo, a mengano, no. Vamos a "hacer el trabajo" (tirar serviço). Entonces, los que usaban mucho esa palabra eran los militares, pero la policía de investigación, la judicial, no, nunca usó ese término. (A3). ${ }^{\mathrm{cl}}$

Los entrevistados relacionaron la tortura, principalmente, con la investigación de delitos patrimoniales por las comisarías especializadas. Casi todos los entrevistados hicieron alguna referencia a lo que ocurría en estas en las investigaciones de todo tipo de delitos, como podemos ver abajo:

¿Hay comisarías que son más proclives a la práctica de la tortura?” 


\section{Dimensiones histórico-sociológicas de la tortura en comisarías de Brasil: el caso Pernambuco}

"Yo estuve al frente de una comisaría (crímenes contra el patrimonio) una vez y alguien vino a decirme que tendría que haber algún nivel de tortura para tener algún tipo de resultado en la comisaría que investigaba los crímenes contra el patrimonio." $(\mathrm{C} 1) .{ }^{\text {cli }}$

En el aspecto ambiental estético no lo veo, pero en lo que respecta a la naturaleza de los crímenes, los que son contra el patrimonio emocionan en la práctica. $(\mathrm{C} 2){ }^{\text {clii }}$

"Mira, desde que yo entré (en la policía) escucho comentarios de que el practicante, esa cosa de los crímenes patrimoniales, el autor de crímenes contra el patrimonio, determinados crímenes contra el patrimonio, solamente se consigue con alguna cosa así... Entonces, no sé, las especializadas que investigan este tipo de crimen..." (CA6). ${ }^{\text {cliii }}$

"Yo tengo la impresión de que las especializadas, principalmente las de crímenes contra el patrimonio. Desde que entré en la policía, yo tengo la impresión de que es el lugar más podrido de la policía. Pero realmente no estoy seguro de eso." (C3). ${ }^{\text {cliv }}$

Seguramente hay. Las comisarías direccionadas a crímenes de difícil resolución, narcotráfico, anti-secuestros, crímenes contra el patrimonio, son comisarías de crímenes complejos. (A1). ${ }^{\text {clv }}$

Totalmente (...) Los propios delincuentes tienen miedo de determinadas comisarías. Tú coges al tipo y le dices: si no cuentas todo, te vas a robos y hurtos, y ya sabes tú cómo son las cosas allí. Yo digo eso porque ya lo vi. (...). Así que hay ciertas comisarías que ya tienen su propia fama. (...) Está el GOE, el propio DENARC, DHPP (...) (A2). ${ }^{\text {clvi }}$

Hay. Robos y hurtos, hurto de vehículos, estupefacientes (A4). ${ }^{\text {clvii }}$

Generalmente son las comisarías que actúan directamente con el delincuente violento: robos y hurtos, hurtos de vehículo, GOE. Esos son más propensos porque trabajan con crímenes más graves... Si ellos la practican, yo no lo sé, pero ellos tienen todos los elementos que provocan los estímulos para que eso pase. (A3). ${ }^{\text {clviii }}$ 


\section{Dimensiones histórico-sociológicas de la tortura en comisarías de Brasil: el caso Pernambuco}

Eso sirve para disminuir la creencia o justificación de policías que atribuyen la práctica de la tortura a razones humanitarias, tales como salvar vidas. También queda claro quién es susceptible de ser torturado ${ }^{176}$. "C12” afirmó que las comisarías más proclives a practicar tortura son las de los barrios pobres, por la falta del abogado que ampare al detenido.

Sí. Generalmente las comisarías localizadas en los barrios más pobres, se permiten más la tortura. Ricos aparecen con abogados y es difícil investigar, a pesar de que para los policías no hay restricciones para torturar ricos o pobres. Las comisarías localizadas en los barrios pobres, por los motivos ya expuestos, y aquellos que practican crímenes violentos como violación, homicidio y robo, además del tráfico de drogas y porte de armas. (C12). ${ }^{\text {clix }}$

Sobre las razones para la práctica de la tortura parece haber un consenso: el resultado fácil. Tanto los entrevistados que admiten haber torturado, como los que dijeron que jamás torturaron explican esta aberración del mismo modo: la presión para obtener resultados y la creencia de que la tortura es una vía segura a tal fin, impulsa su práctica.

Los que admitieron que habían torturado lo justificaran así:

Exactamente. La responsabilidad del resultado, la responsabilidad final es del comisario. Entonces la presión de la sociedad, la suya propia, es mucho mayor. Y muchas veces para afirmarse delante de los propios policías. (C1). ${ }^{\mathrm{clx}}$

176 “' 'Os piores crimes são feitos por filhos de papai, porque nestes a gente não pode por a mão, eles têm toda a cobertura de políticos, de magnatas e da própria polícia' (69); 'nos casos que tem gente grande envolvida, você começa a mexer, mas tem que parar quando chega neles, senão vai para a Corregedoria e lá eles falam que a gente está caluniando, prensando' (70); 'se você vier bem vestido, com todos os dentes, limpinho, você é ouvido, mas muito raramente é preso' (71)” (PAIXÃO, 1980: 20). 


\title{
Dimensiones histórico-sociológicas de la tortura en comisarías de Brasil: el caso Pernambuco
}

En realidad entiendo, de cara a la realidad de las condiciones, que los crímenes contra el patrimonio muestran una cierta necesidad de violencia en el trato con los criminales, y traen consigo un cierto recto código de honor y la presión por el resultado inmediato en los crímenes de esta naturaleza apuntan para métodos de este tipo. (C2). ${ }^{\text {clxi }}$

Los dos entrevistados que dijeron que jamás habían torturado también explicaron esa práctica a través del resultado:

\begin{abstract}
Hice esta pregunta en algunos grupos de policías, en cursos de formación y en cursos de perfeccionamiento, en los cuales tuve la oportunidad de impartir clases. Las respuestas: obtener pruebas ("tirar serviço"), incluso confesión; castigar al criminal; perversidad del policía (sadismo); humillar al criminal. (C4). ${ }^{\text {cxii }}$
\end{abstract}

Para mostrar resultados. No siempre hay pruebas suficientes ni medios para encontrarlos. No quieres ser conocido como incompetente, quieres ser promovido, quieres recibir las recompensas por los resultados... (C3). ${ }^{\text {clxiii }}$

Por sadismo y otras enfermedades emocionales; por crueldad y deformación del carácter; por permisividad y omisión de los órganos de control; por total falta de preparación y desconocimiento de la misión a la que se presta; por ausencia de métodos científicos y adecuados de investigación; por permisividad de la sociedad. (CA5). ${ }^{\text {cxiv }}$

Falta claridad en los entrevistados sobre hasta dónde es prescindible la tortura. Incluso cuando los comisarios demostraban ser irreductibles sobre su posición de no practicarla, parecían tener dudas o comprender cuándo otros la practicaban. Por al parecer, todos la ven como "eficiente", aunque la rechacen o prefieran otros métodos, reconocen que esa práctica produce "resultados" y sostienen que fundamentalmente está dirigida a obtenerlos. 


\section{Dimensiones histórico-sociológicas de la tortura en comisarías de Brasil: el caso Pernambuco}

Para C1, que ya torturó en un determinado momento de su carrera como comisario, la tortura no era "eficiente" y había conseguido probarlo, pues fue destinado a una comisaría que tenía una larga tradición al respecto. Cuando C1 prohibió explícitamente el uso de la tortura, dejando muy claro que quien la practicase sería responsabilizado por eso, pudo verificar que después de casi dos años en la dirección de esa comisaría, el número de investigaciones resueltas antes (con tortura) y después de su llegada (sin tortura) eran iguales o mejores.

\footnotetext{
"ellos con toda aquella tortura hicieron muchos interrogatorios. Uno consigue descubrir un crimen tal y hace un interrogatorio, ¿vale?, identifica al autor de aquel crimen, reúne las pruebas y hace un interrogatorio. Ellos tenían una media de interrogatorios que, incluso yo con menos escribientes y menos comisarios, porque yo tenía menos escribientes y comisarios que ellos, yo conseguí hacer igual o un poquito más, y la tortura era la regla, la regla (para el equipo anterior). Por lo tanto, si la tortura fuera muy eficiente, la regla sería que sin tortura habría caído drásticamente la realización de interrogatorios." (C1). ${ }^{\text {clxv }}$
}

Su conclusión era que trabajando con menos policías y comisarios que en el período en que se torturaba, la comisaría bajo su mando (sin tortura) había mejorado en algunos casos o había quedado igual en en número de atestados (inquéritos investigaciones) con relación al período antecedente. Para él no había duda que era posible mantener o mejorar la gestión policial sin utilizar la tortura. Aunque no le satisfacía plenamente poder superar, sin tortura, los números de investigaciones resueltas por los que torturaban, era una manera de confirmar su carencia de ventaja comparativa.

Por otra parte, pese a haber llegado personalmente a la conclusión de que no se necesita la tortura para ser considerado "eficiente", él reconoce que otros piensan de modo diferente: 


\section{Dimensiones histórico-sociológicas de la tortura en comisarías de Brasil: el caso Pernambuco}

El deseo de echar mano de ese discurso como una forma de mostrar resultados es latente. Yo vi a gente recién nombrada, vi a gente que había cumplido 30 años, vi a gente que entró en la policía recientemente y que vino de la clase media, sin ningún problema financiero que solucionar, sin cosas pendientes, sin una pena, ¿vale?, digamos así profunda, con traumas, echar mano de ese discurso por tenerlo como eficiente. Siempre hay esa tentación, entre comillas, de echar mano porque da resultado, y quiere mostrar resultados. $(\mathrm{C} 1){ }^{\text {clxvi }}$

Y en la misma línea,

Si no hay un gran castigo, siempre habrá tortura porque es mucho más fácil que pedir autorización para hacer una escucha, mandatos, reunir pruebas, convencer a alguien para ser testigo, etc. $(\mathrm{C} 3){ }^{\text {clxvii }}$

Mientras CA6, comisaria que dijo que jamás practicó la tortura, y afirmó categóricamente que jamás la practicaría, al responder a la cuestión de si los resultados de la policía serían menores si se excluyese la tortura ella contestó que tenía dudas:

Realmente yo no sé si sin esta práctica, si los resultados de las investigaciones serían peores, realmente no sé... (CA6). ${ }^{\text {clxviii }}$

Y para C3, C2 y C4 la tortura es "eficiente" (o puede serlo):

Es eficiente. Moralmente inaceptable, pero en la mayoría de los casos eficiente. (C3). ${ }^{\text {clxix }}$

Depiende de la ótica. $(\mathrm{C} 2){ }^{\text {clxx }}$

Sí, en términos de producción de investigación. (C4). ${ }^{\text {clxxi }}$ 


\section{Dimensiones histórico-sociológicas de la tortura en comisarías de Brasil: el caso Pernambuco}

\subsubsection{Ascenso/prestigio}

Muy explicativo resulta comprobar que los entrevistados creen - aunque con matices - que la tortura puede influir de manera positiva en el ascenso profesional o que la relación entre costes y beneficios de su práctica es positiva.

“A quién prefieren los jefes, a un policía que tortura y consigue buenos resultados o a uno que no tortura y obtiene menos resultados?"

Yo creo que sí. Yo creo que sí. Es como aquel comportamiento, aquella cosa, mientras no pase nada, mientras no salga a la luz es como si fuera absuelto en nombre del resultado. (C1). ${ }^{\text {clxxii }}$

Seguro que prefieren a esos que torturan y traen resultados, pero que no traen problemas legales. (C2). ${ }^{\mathrm{cl} x \mathrm{xii}}$

Creo que ellos prefieren no saber cómo aparecieron los resultados, desde que aparezcan. Si los resultados son buenos ellos se llevan los laureles porque fueron buenos administradores. Si aparece alguna historia de tortura, como ellos no lo sabían y no participaron, aun podrán decir que los culpables serán severamente castigados, etc. O sea, otra razón por la que creo que sólo les importan los resultados es porque jamás vi una campaña o declaración de ningún jefe de policía en contra de la tortura. (C3). ${ }^{\text {clxxiv }}$

Los jefes que también son malos, prefieren a los policías malos. Si es un buen jefe y preparado, difícilmente va a preferir un mal policía (CA5). ${ }^{\mathrm{clxxv}}$

La primera opción, lógicamente. Pero eso es peligroso, pues muchos jefes no van a querer comprometerse, si se descubre. $(\mathrm{C} 12){ }^{\mathrm{cl} x x v i}$ 


\section{Dimensiones histórico-sociológicas de la tortura en comisarías de Brasil: el caso Pernambuco}

Creo que en el pasado eran los que torturaban y mostraban resultados, pero esa realidad está cambiando. (C13). ${ }^{\text {clxxvii }}$

Depende del tipo de trabajo. El comisario de una ciudad tranquila no quiere problemas con la tortura, pero el comisario de una circunscripción dura, ese quiere al torturador. (A1). ${ }^{\text {clxxviii }}$

La mayoría de las veces yo creo que sí. Porque la persona del comisario vive del resultado que muestra. Estás en la comisaría del Espinheiro y rindes, está todo el mundo contento contigo. Si no rindes, van a mandarte para Cabrobó y esconderte allí. Un comisario no quiere eso para él, él quiere destacar. Entonces, si él está poniendo las manos en la masa, pero tiene resultados, eso fue con la mayoría con los que yo trabajé, entonces su equipo está bien. El equipo está dando el resultado que él quiere. Los líderes de la Policía Civil están más preocupados con números y con las "caritas" (índice de evaluación de resultados) que con lo que se anda haciendo en las calles. (A2). ${ }^{\text {clxxix }}$

Eso va a depender del jefe. (A4). ${ }^{\text {clxxx }}$

¿Y en las últimas 4 comisarías en que trabajó cuál era el perfil del jefe?

Infelizmente eran violentos. (A4). ${ }^{\text {clxxxi }}$

También llama la atención la creencia de que si practicasen la tortura podrían ascender en la carrera más rápido. Si bien la mayoría hace depender la promoción del "resultado" obtenido torturando (o no), lo que todos tienen claro es que torturar no impedirá en todo caso dicha promoción. 


\section{Dimensiones histórico-sociológicas de la tortura en comisarías de Brasil: el caso Pernambuco}

“Crees que si su equipo practicase la tortura como método de investigación, vosotros tendríais un ascenso más rápido o seríais más elogiados?"

Conocí varios casos de comisarios que eran conocidos torturadores y ocuparon puestos más significativos dentro de la estructura policial. Tanto de la civil como de la militar. (C1). ${ }^{\text {clxxxii }}$

¡Sin duda! (C3). ${ }^{\text {clxxxiii }}$

Evidentemente. Eso ya ocurrió varias veces con otros policías. (CA5). ${ }^{\text {clxxxiv }}$

En mi institución, sí. Incluso conozco casos de esta naturaleza. (C4). ${ }^{\text {clxxxv }}$

Claro que sí, pues nadie diría que todo fue hecho por medio de la tortura. (C12). ${ }^{\text {clxxxvi }}$

Creo que no. (C13). ${ }^{\text {clxxxvii }}$

No. Existen varios factores, lo que es necesario es hacer y es dar resultados. (C2). ${ }^{\text {clxxxviii }}$

Si ese equipo, con tortura o no, consigue los resultados a los que aspiran los superiores, va a ascender. Lo que importa son los resultados. (A1). ${ }^{\text {clxxxix }}$

Yo creo que practicando la tortura se llega al resultado, entonces si ese resultado te lleva por ese camino, entonces yo no podría negar esa realidad. (A2). ${ }^{\text {cxc }}$

Diez de once entrevistados conocían a personas que fueron ascendidos y eran reconocidos como torturadores habituales. 


\section{Dimensiones histórico-sociológicas de la tortura en comisarías de Brasil: el caso Pernambuco}

“¿Conoces a alguien que siendo conocido por la práctica de la tortura aún así fue ascendido o elogiado o es muy reconocido por los compañeros?"

Yo creo que eso pasa. No es por la práctica de la tortura. Es algo como, ellos son conocidos como policías que eventualmente hacen determinados, ¿vale? ellos usan esas prácticas, pero eso no impide que asciendan, que sean promovidos dentro de los cargos de comisarios ni que asuman puestos más altos en comisarías que son importantes. (CA6). ${ }^{\text {cxi }}$

Varios. (C3). ${ }^{\text {cxcii }}$

Sí. Policía operacional da resultado. (C2) ${ }^{\text {cxciii }}$

Conozco a algunos que lo son y otros que, con las mismas prácticas, no lo son. Si consigue resultados (concluir interrogatorio con autoría), es promovido, reconocido, elogiado. $(\mathrm{C} 4)^{\text {cxciv }}$

Seguro. No sólo uno, sino una unidad entera de policías. El buen torturador era también idolatrado y poderoso, además de ser temido. Era reconocido como un hombre fuerte y muchas veces líder. (CA5). ${ }^{\text {cxcv }}$

Sí, muchos. Los resultados lo mostraron. (C12). ${ }^{\text {cxcvi }}$

Sí que conozco. En la época en que eso ocurrió, la cúpula de la Policía valoraba los resultados, se obtuviesen como se obtuviesen. (C13). ${ }^{\text {cxcvii }}$

Conozco. (A1). ${ }^{\text {cxcviii }}$

No. Así, explícitamente conocido no. No fue promovido por eso. Entonces el sistema no reconoce eso. El sistema asciende al comisario que llegó al resultado. Cómo llegó al resultado, no interesa... (A2). ${ }^{\text {cxcix }}$ 


\section{Dimensiones histórico-sociológicas de la tortura en comisarías de Brasil: el caso Pernambuco}

Conozco a varios. Rápidamente ascendidos. Yo tardé 18 años en ascender y conozco compañeros que fueron ascendidos en 6 años, gracias a ese tipo de trabajo. (A4). ${ }^{\text {cc }}$

Hay... Hay, muchos. (A3). ${ }^{\text {cci }}$

Todos vincularon el ascenso a los resultados (aunque estos fueran obtenido a través de la tortura), de aquí que la tortura puede ser utilizada con el fin de ascender si con ella se obtuvieran buenos resultados.

¿Por qué?

Creo que por los buenos resultados. Resulta difícil decir que todo resultado fue utilizando eso ahí porque no conocemos el día a día, la práctica, sería imposible decir eso. Pero si asciende no es porque usó esta práctica, sino porque demostró un buen trabajo por donde pasó. (CA6). ${ }^{\text {ccii }}$

Por los buenos resultados. Ahora mismo hay una política de premiar en función de los resultados. Incluso hay encuentros con el Gobernador donde vas a explicar tu éxito o tu fracaso. Dudo mucho que el gobernador, o cualquier jefe, antes de premiar algún comisario por el éxito de su trabajo vaya a investigar si anda torturando. El gobernador, el jefe de policía, el director, de esa o de cualquier otra Policía está preocupado con los números. Pues de eso depende su permanencia en el poder (cadeira preta). Con la tortura, ellos sólo se van a preocupar si estalla algún escándalo en la prensa. Ahí van a decir que no toleran eso, que van a investigar, bla, bla, bla. (C3). ${ }^{\text {ciii }}$

¿Es posible que la usen como forma de ascenso profesional? 


\section{Dimensiones histórico-sociológicas de la tortura en comisarías de Brasil: el caso Pernambuco}

Ocurre que a veces incluso cuando a un policía se le da la misión de investigar un crimen de repercusión (...). Entonces él va a usar el método que ya usaba para obtener un resultado rápido, porque él sabe que va a ser elogiado por el gobernador, por la sociedad, que va a tener la foto en el periódico. Y muchas veces va a tener una carrera meteórica en la policía y puede ser hasta fuera de ella, como hacerse político por ejemplo. (...). (C1). ${ }^{\text {cciv }}$

Sí. En cuenta de los resultados. (C2). ${ }^{\text {ccv }}$

Sí. Buenos resultados generan elogios y ascensos. (C3). ${ }^{\text {cvi }}$

Sí. Esto pasó cuando un alto mando de la policía era, reconocidamente, un policía adepto a la práctica de la tortura. $(\mathrm{C} 4){ }^{\text {ccvii }}$

No sólo es posible como todavía se utiliza, desgraciadamente. No creo que actualmente sea el primer criterio, pero aún cuenta, con un gran peso para el modelo de policía que aún domina en nuestras sociedades. (CA5). ${ }^{\text {ccviii }}$

Por supuesto. La propia sociedad comulga con el pensamiento de que hay que pegarle al criminal. Ya me ocurrió una vez que, una señora que había sido atracada, al descubrir que su nieto estaba involucrado en el crimen, me pidió que le diera una paliza. (C13).). ${ }^{\text {ccix }}$

Creo que las personas ascienden profesionalmente por el trabajo realizado, pero nadie va a analizar si lo consiguió por medios ilegales. (C12). ${ }^{\text {ccx }}$

Exato. (A4). ${ }^{\text {ccxi }}$ 


\section{Dimensiones histórico-sociológicas de la tortura en comisarías de Brasil: el caso Pernambuco}

Podemos confirmar la creencia en el "valor" de la tortura, como forma de ascenso profesional cuando preguntamos cuál era el beneficio derivado de practicar la tortura, que nadie negó.

\section{¿Cuáles son los beneficios?}

Se ganan la confianza del jefe, que muchas veces no admite la tortura pero al que le gusta el resultado. (...) Sí y mucho. En la ciudad del área metropolitana donde trabajé, la utilización de la tortura dio un resultado positivo en la disminución de la violencia. El número de homicidios en el área cayó más de la mitad en media cada mes (...) Creo que ningún policía siente placer en hacerlo. Lo hace para agradar a la autoridad y decir que consiguió investigar y arrestar a alguien, sin embargo, masoquismo yo no he conseguido verlo todavía. (C12). ${ }^{\text {ccxii }}$

Proyección profesional (...) Algunos resultados acaban ocurriendo, pero siempre hay riesgos de que se cometan injusticias y de una fragilidad de la autoridad cuando se somete a practicar crímenes para solucionar otros. $(\mathrm{C} 13){ }^{\text {ccxiii }}$

La sensación del deber cumplido. La satisfacción de llegar con el resultado al jefe. A lo mejor quiere ser más policía, más hombre que el otro. (A4). ${ }^{\text {ccxiv }}$

El agente quiere verse reconocido por su comisario. Quiere que el comisario lo mire y le diga que él tiene un policía que le muestra resultados. "Yo tengo un policía competente; yo tengo un policía en el que confío, al que yo le voy a dar determinado caso y él lo va a solucionar para mí’. Entonces, el agente quiere tener esa relación con el comisario. Él quiere agradar al comisario, que el comisario se sienta bien trabajando con él... Entonces, la mayoría de los policías civiles, incluso yo, quiere hacerse un nombre en la institución, quiere ser reconocido. Cada uno usa sus medios para hacer eso. Unos usan la tortura, otros usan medios burocráticos. Tú quieres conseguir tu espacio en la policía civil... (A2). ${ }^{\mathrm{ccxv}}$

Credibilidad, privilegios, promociones, respeto de los compañeros y del jefe. (A3). ${ }^{\text {ccxvi }}$ 


\section{Dimensiones histórico-sociológicas de la tortura en comisarías de Brasil: el caso Pernambuco}

\subsubsection{Tortura y corrupción}

Uno de los aspectos más interesantes que surge de los discursos de los entrevistados es la asociación de la tortura con la corrupción ${ }^{177}$. Y de cómo la práctica de la tortura para obtener informaciones sobre una investigación puede derivar fácilmente en una práctica que busca obtener ganancias ilícitas.

Preguntados sobre si había una relación entre tortura y corrupción, once de doce entrevistados que contestaron esa pregunta afirmaron que sí, hay relación entre tortura y corrupción.

\footnotetext{
"Ahora, me parece que la tortura queda más impregnada en cualquier red policial cuando existe el componente de la corrupción porque el tipo se obcecado en obtener un resultado no sólo para presentar al jefe, sino porque también tiene prisa para tener dinero en el bolsillo (...). Es sólo que hay un componente que no pensamos cuando hablamos de tortura. Creo que también lo pensamos pero no lo decimos. Donde existe tortura como práctica rutinaria existe ganancia de dinero para las personas que participan en ello. El tío de la comisaría, existe mucha tortura principalmente en las comisarías de crímenes contra el patrimonio. En estas comisarías de crímenes contra el patrimonio donde la tortura es una cosa permanente, rutinaria, se gana dinero, sea de la víctima, sea por la extorsión al propio delincuente." (C1). ${ }^{\text {ccxvii }}$
}

Gran relación. No hay ningún freno frente a la corrupción para quién tortura sistemáticamente, o sea, el tipo coge el dinero. (C2). ${ }^{\text {ccxviii }}$

Sí. Me he enterado de algunos casos de esa relación, cuando la intención era "librar" al corrupto. (C4). ${ }^{\text {ccxix }}$

\footnotetext{
${ }^{177}$ Aquí usamos la palabra tortura solamente en el sentido jurídico de sobornar el agente público con dádivas para hacer o dejar de hacer algo en contra de la ley.
} 


\section{Dimensiones histórico-sociológicas de la tortura en comisarías de Brasil: el caso Pernambuco}

Estricta e íntima relación. (CA5). ${ }^{\text {ccxx }}$

En mi cabeza tortura y corrupción están más asociadas a las (comisarias) especializadas. Ya trabajé en homicidios y no allí vi casos de tortura. Tal vez en las especializadas en crímenes contra el patrimonio. (C3). ${ }^{\text {ccxxi }}$

Existe una cierta relación porque el propio delincuente no quiere sufrir. Si vas a "trabajarte" determinado delincuente y él sabe que está en sus manos puede darte determinada ventaja. Yo estoy totalmente en contra, pero ya lo he visto, o sea, ya lo he oído... Principalmente en comisarías como el DENARC (comisaría especializada en el combate a las drogas), donde el delincuente ya tiene una cuantía preparada para el policía. Prefiere dar esa gran ventaja, a que le peguen y lo arresten... (A2). ${ }^{\text {cxxii }}$

Iba todo junto, porque para que tú consiguieses algo, y el tío con miedo de ser torturado, pues te lo ponía fácil. Para que al tipo no le pegasen, conseguía (el dinero). Generalmente, iba del jefe al último peón. Del primer escalafón al último. Era mucho más que ahora. (A3) (cxxiii $^{\text {cxii }}$

Hay, hay una relación. La tortura muchas veces se usa para que la persona descubra un beneficio para ellos. Muchos policías van por esa línea. (A4). ${ }^{\text {ccxiiv }}$

... tú practicas la tortura para castigar al autor de un crimen contra una persona rica que seguro va, seguro va a darte dinero, tú practicas la tortura para recibir información de coches robados para que los devuelvas al propietario y eso va a darte dinero... Yo creo que gran parte de la tortura está unida a la corrupción por la necesidad que tienes de la compensación de la ventaja ilícita que vas a tener. (C14). ${ }^{\text {cxxv }}$

Normalmente, policías torturadores acaban corrompiéndose. De tanto vivir al margen de la ley, ellos creen que necesitan ser recompensados con algún tipo de ingreso extra. (C13). ${ }^{\text {ccxxvi }}$

No. Tengo policías que torturan y son honestos. Seguro. $(\mathrm{C} 12){ }^{\text {ccxxvii }}$ 


\title{
Dimensiones histórico-sociológicas de la tortura en comisarías de Brasil: el caso Pernambuco
}

\begin{abstract}
Algunos hacen mención explícita de como la corrupción y tortura están identificadas con las comisarías especializadas en crímenes contra el patrimonio.
\end{abstract}

\subsubsection{Medios disuasorios de la tortura}

\subsubsection{Presión interna}

\subsection{Academia de Policía}

La Academia es el primer contacto que alguien tiene cuando entra en la policía. Los valores, las técnicas ${ }^{178}$, la experiencia, el ethos. Todo eso será, o debería ser, visto por primera vez en la Academia. Y es justamente por eso que no se puede descuidar de lo que llamamos formación profesional.

Las organizaciones de policías en América Latina estuvieron alejadas de la sociedad por un largo período. Esa situación empezó a cambiar en la última década cuando la policía empezó a buscar una mejor integración con la comunidad y, al mismo tiempo, a preocuparse con la realización de estudios teóricos más cercanos a

178 "Uma área importante de preocupação é a questão das técnicas de interrogatório, já que policiais carentes de formação e dos recursos necessários para empreender investigações de forma profissional e científica passaram a considerar as confissões assinadas como único meio de assegurar a ação legal'. (AMNISTIA INTERNACIONAL, 2001: 21). 


\section{Dimensiones histórico-sociológicas de la tortura en comisarías de Brasil: el caso Pernambuco}

los nuevos paradigmas del proceso de democratización de las sociedades. Pero ese cambio es lento, gradual y, muchas veces, se retrasa por falta de interés corporativo en cambiar ${ }^{179}$.

Para Soares (2002: 26) es necesario salvar la policía del pasado, tornarla contemporánea del presente democrático y reinventarla para un nuevo contexto político. Es preciso sacarla del armario en que guardamos los fantasmas históricos. Librar a la policía del pasado significa invertir su identidad y sus fines institucionales: ella existe para garantizar las libertades y derechos, consagrados en las leyes, inscritos en la Constitución democrática. Ella sólo puede exigir que las personas cumplan las leyes si es la primera en cumplir.

Parece que las prácticas no se coadunan con los discursos de una "policía ciudadana" integrada en un Estado Democrático de Derecho. ¿Si el discurso es “proteger y servir”, dónde están los policías aprendiendo a “torturar y matar”? ¿Hasta qué punto las instituciones policiales favorecen la asimilación de comportamientos violentos, o, caso contrario, ayudan a disminuir tales características aprendidas a través de las relaciones sociales?

Considerando que el objetivo de la policía es el de posicionarse como una "policía ciudadana" y mantenedora del respeto a las leyes; considerando que cualquier entrenamiento y, aún más, una "formación”, busca atender a los objetivos predeterminados de las instituciones a que se vinculan, entonces, sólo hay un corolario posible para ese caso: el de que cualquier entrenamiento y, mucho más, cualquier formación policial pretende preparar a sus miembros para desarrollar tareas policiales con estricta observancia de los principio de ciudadanía.

179 "Los agentes desarrollan una sensibilidad especial por las formas, y suelen tener actitudes conservadoras ante nuevos valores. Como todas las profesiones y organizaciones, la Policía tiene sus propias teorías y visiones sobre la realidad. Uno de los procesos más interesantes es cómo los/as agentes nuevos pasan por diversos ritos mientras internalizan esos contenidos simbólicos y construyen parte de su identidad social basándose en él. El proceso comienza con la selección y socialización de nuevos miembros en un proceso de formación”. (ROBLES, 1997: 41). 


\section{Dimensiones histórico-sociológicas de la tortura en comisarías de Brasil: el caso Pernambuco}

No hay como imaginar resultado distinto para este silogismo, a menos que la policía sea incompetente para planear su formación con el fin de atender sus objetivos. O que por el contrario, sea bastante competente para establecer una falsa premisa: "policía ciudadana", lo que permitiría huir de la fuerte presión de las organizaciones no-gubernamentales e incluso gubernamentales.

Tal afirmación puede ser sostenida incluso considerando los diferentes fines dados a la formación policial. Sea como un "factor clave para los cambios" (PostGary 1992; Burger 1998; Palmiotto 2000), sea relativizada en razón de la influencia del propio trabajo policial (Gayre et alli 1996) o de su "cultura corporativa" (Albuquerque \& Machado, 2001). Antes de examinar si determinada formación produjo los resultados deseados, conviene esclarecer a que pretendía tal formación.

La educación técnica busca, en principio, transmitir contenidos específicos para el desarrollo de determinadas tareas y, al mismo tiempo, contenidos generales de carácter pedagógico, social, político y filosófico que permitan una mejor compresión y participación de la vida en sociedad. Incluso cuando se dirige exclusivamente al conocimiento técnico, la acción educativa expresa posiciones ideológicas que, aunque no estén en los currículos oficiales, está presente, de forma implícita en el ambiente profesional. Tal fenómeno puede ser entendido como el aprendizaje a través de actitudes, comportamientos, valores y orientaciones que permiten una asimilación de reglas corporativas "invisibles" que facilitan la aceptación en el grupo del educando y posibilitan su creciente funcionalidad.

No obstante, en cualquier de los dos casos, el aprendizaje está impregnado de “razones" políticas ${ }^{180}$, pues, antes de todo, procede de una serie de elecciones

\footnotetext{
$180 \quad$ "O interesse - às vezes manifesto - de políticos e ideólogos é que os estudantes saiam da instituição escolar não apenas preparados para as funções que terão de desempenhar no contexto social (socialização funcionalista), mas também, e sobretudo, perfeitamente harmonizados com a concepção de mundo, com o tipo de homem e sistema social mais próximos da ideologia que sustentam”. (GUTIÉRREZ, 1998: 20).
} 


\section{Dimensiones histórico-sociológicas de la tortura en comisarías de Brasil: el caso Pernambuco}

políticas: la elección de establecer una actividad; la creación de criterios para postular el servicio; la disposición de la capacitación profesional y la estipulación del perfil profesional deseado.

Si la educación básica es implementada por la necesidad de ratificación de los fundamentos de un sistema político ${ }^{181}$, preparando a las futuras generaciones para actuar en conformidad con sus principios, no podría ser distinto el caso de la educación profesional, tanto más cuanto que los educadores tienen la facilidad de trabajar con grupos específicos. Tal formación, por si sola, no tiene el poder de transformar, corregir o modificar fenómenos sociales. Pero puede contribuir, ratificar, fomentar tales fenómenos, de forma considerable. Admitiendo que un fenómeno socio-político puede ser alterado o mantenido a través del uso de la represión o de la ideología, tenemos en la formación policial la combinación de esos componentes explosivos. De ahí la razón para no descuidar su dirección políticoideológica, incluso porque es indispensable una elucidación de los objetivos de esa formación.

Aunque su lema sea el de la "seguridad ciudadana", la policía da más miedo que seguridad. Es la primera en incumplir las leyes que justifican su propia existencia. Tortura, mata, corrompe y discrimina a determinados segmentos de la sociedad. Comprender eso implica comprender la distancia entre discursos y prácticas, distinguiendo cuál es el valor de un eventual discurso formal de "proteger y servir", cuando en los cánticos internos cantan, diariamente, algo bien distinto:

181 "A escola é a instituição social que, por sua natureza, suas funções e estrutura, cumpre, como nenhuma outra, objetivos políticos. O sistema escolar, de qualquer sociedade, é o reflexo fiel da política e da ideologia dos grupos governantes e dos partidos políticos no poder". (GUTIÉRREZ,, 1998: 17). 


\section{Dimensiones histórico-sociológicas de la tortura en comisarías de Brasil: el caso Pernambuco}

“'Soldado do BOPE mais temido do Brasil’, grita el jefe. Y los policías contestan: 'Mata um, mata mil!' "182 o “(...) faca, faca, faca, na caveira (...)"183.

Es importante analizar las divergencias entre el discurso corporativo ${ }^{184} \mathrm{y}$ el discurso de los alumnos, preguntando, constantemente, en qué medida la orientación político-ideológica de la formación policial puede contribuir al mantenimiento de graves violaciones de los derechos humanos. Y no se puede buscar significados distintos que "contribuir", pues, como ya fue dicho, hay muchos factores que convergen para que tenga lugar la violencia y, además, aunque no hay corporación que pueda tener la violencia como un fin en si mismo, si puede considerarla el "medio" para alcanzar sus fines.

Cuando la educación practicada en una institución policial no produce los resultados que ella mismo declara, no siempre se puede decir que ella falló. Puesto que puede haber alcanzado plenamente otros objetivos, no declarados, pero muy relevantes según sus dirigentes. Es necesario comprender las contradicciones entre los discursos institucionales y sus respectivas prácticas, sin olvidar que, si bien no siempre buenos contenidos generan buenos resultados (pues pueden carecer de una eficiente metodología), jamás veremos que malos contenidos generaren buenos resultados (sea cual sea el método).

De acuerdo con las contestaciones de los entrevistados la Academia no cumple su papel, al menos el papel oficial, aquello que está en sus principios y

182 GOIS, Anselmo. Soldados cantam bordão curioso durante Cooper. Jornal do Comércio, Ano LXXXIII, $n .^{\circ} 273, p .2$, 30/09/02.

183 Canción utilizada por la Companhia Independente de Operações Especiais - CIOE/PM/PE y muy utilizada en las academias de polícia militares.

$184 \quad$ "Sabe-se que o currículo corresponde a uma seleção da cultura, realizada em um universo mais amplo de possibilidades. Ao enfatizar determinados saberes e ao omitir outros, essa seleção expressa uma posição político-ideológica que opera a favor dos interesses de determinados grupos." (CANEN, Ana. MOREIRA, C4 Flavio B. (Orgs.). Ênfases e omissões no currículo. Campinas/SP: Papirus Editora, pág. 7, 2001.). 


\section{Dimensiones histórico-sociológicas de la tortura en comisarías de Brasil: el caso Pernambuco}

anuncios institucionales. Jamás se dan clases para enseñar a torturar, pero jamás se hace hincapié en inhibir tal práctica. Eso permite que en los intervalos entre clases, la idea de la tortura crezca con mucha naturalidad.

Preguntados sobre la eficiencia de la Academia en el combate al delito de tortura, la contestación más descomprometida, o favorable, es la falta de recuerdos. La peor, es la de los que la recuerdan como "eficiente" en prepararlos para ver la tortura como algo normal. En el mejor de los casos, los entrevistados o no recuerdan que el tema hubiese sido abordado durante el período que estaban en la Academia, o, cuando lo recuerdan, afirman que fue poco o nada tratado. Con los agentes de policía fue aún peor, pues ellos tenían mejores recuerdos de sus tiempos en la Academia. Según ellos había profesores que decían que los policías de verdad tenían que torturar y había profesores que no conseguían disuadir los grupos de alumnos que defendían la tortura durante la clase de derechos humanos.

Cuando fueron preguntados sobre el tratamiento que el tema de la tortura tuvo en el currículo y por los profesores, la contestación más benévola fue la de que no conseguían recordar que se hablara de ello.

Cuando fui alumno de la Academia no se tocaba en el asunto de la tortura, era como si no existiera, y en aquella época existía mucho más que hoy. $(\mathrm{C} 1){ }^{\text {ccxxviii }}$

No. Los contenidos jamás abordaban el tema tortura. Ese era un asunto tabú. Yo sabía que los policías torturaban, pero en la Academia estaba prohibido hablar sobre el tema. (CA5). ${ }^{\text {ccxix }}$

Este tema no formaba parte del contenido del curso de formación. En realidad, había algo de recelo en tocar este punto, por parte de los alumnos y de los profesores. Algunos profesores hicieron referencia al tema, pero de forma vaga. (C4). ${ }^{\text {ccxxx }}$

No me acuerdo. Hace mucho tiempo. No me acuerdo si ese tema fue discutido. (CA6). ${ }^{\text {ccxxxi }}$ 


\title{
Dimensiones histórico-sociológicas de la tortura en comisarías de Brasil: el caso Pernambuco
}

\begin{abstract}
No consigo acordarme de si este tema fue abordado durante el curso de formación. Me acuerdo que había un exceso de materia jurídica y que los alumnos estaban más preparados que los profesores, pues los alumnos habían estudiado para hacer las oposiciones que iban apareciendo y los profesores eran comisarios que estaban muy desactualizados. (C3). ${ }^{\text {ccxxxii }}$
\end{abstract}

No hubo en la academia este tipo de informaciones, pues mi academia duró sólo 45 días. (C12). ${ }^{\text {ccxxxiii }}$

Mientras en el primer bloque de entrevistados (comisarios) no había recuerdos muy significativos del contenido de las clases recibidas, y sí de lo transmitido fuera de ellas, en los corredores de la Academia, del "currículo oculto", en el bloque de entrevistas con agentes de policía se evidencia la importancia de lo recibido en las clases. Para nuestra sorpresa hubo quien las recordaba casi 30 años después y, también teníamos entrevistas de policías recién salidos de la Academia que se referían a ellas en detalle.

La Academia representa los primeros pasos del policía y el primero contacto con los valores y los principios de la corporación. Lo que vamos a ver a continuación es cómo empieza la formación de una policía violenta, que tortura mientras las autoridades firman tratados de derechos humanos. Los entrevistados afirman que hay dos tipos de profesores: los que defienden la tortura y los que la critican. Pero, fuera de la clase, el discurso informal de los alumnos, es casi unánime en tratarla como algo normal o imprescindible.

A diferencia de la Policía Militar que tiene una formación más regular, en la policía civil la formación es casi siempre una formalidad, donde un curso que debería tener al mínimo 6 meses, es concluido en 40 días; donde un policía debería experimentar al mínimo 200 disparos de arma de fuego, concluye con 3 o 5 disparos; tiene clases de legítima defensa donde no aprende el mínimo de defensa. O sea, hay una simulación de una formación policial. El problema es que los policías no 


\section{Dimensiones histórico-sociológicas de la tortura en comisarías de Brasil: el caso Pernambuco}

aprenden el currículo oficial, pero aprende el no oficial o informal, "oculto" "185. Hay una tradición oral muy fuerte donde el policía más viejo enseña al recién llegado.

¿Cómo fue tratado el tema de la tortura en la Academia de Policía?

Yo tuve la oportunidad de cursar dos academias, una de policía militar y una de policía civil, la última la estoy haciendo ahora. En ambas ese asunto fue bastante abordado. La declaración de los derechos humanos era leída y releída diversas veces. Pero siempre fue colocado de forma dogmática. Decían, mira, no puedes torturar. Tortura es crimen. Siempre de forma mecánica. Nunca se buscaba un abordaje del por qué, del cómo, para qué. Sobre ese asunto. Era hasta medio místico, era una asignatura pequeña donde la función única del instructor era repasar a los alumnos, vosotros seréis policías y no podéis torturar. Existe esa declaración de los derechos humanos, que os voy a leer, y existe la ley para los crímenes aberrantes y si vosotros lo hacéis seréis despedidos. E incluso arrestados. Sólo eso. De forma muy superficial. (A1). ${ }^{\text {ccxxxiv }}$

Este tema, por ser un tema actual, fue muy abordado durante la academia. Siempre subrayando bien que el policía civil debería tener plena conciencia de los derechos humanos... Las clases eran más formales, daban parte de la legislación específica de los derechos humanos, de la tortura. Pero no trabajaban con casos reales, ni había ninguna discusión ética. Eran más positivistas. $(\mathrm{A} 2) .{ }^{\operatorname{ccxxxv}}$

En mi época, entre el 82 y el 83, era interesante porque había un profesor que defendía la violencia, él decía que el policía tenía que ser bruto. Enseguida salía ese profesor y entraba una profesora diciendo que no podía ser así, que tenían que ser tratados correctamente... Existía ese juego: el profesor diciendo no le hagáis caso a la profesora porque ella quiere hacerlo todo bien bien, coger al delincuente en brazos... ¡Delincuente funciona a palos! La profesora decía no hagáis eso no, porque os van a expulsar a

185 Investigadores americanos ya demonstraban que los policías aprenden mucho más con sus companeros de trabajo que en las acadénmias (Bayley \& Bittner, 1984; Skolnick, 1966). 


\title{
Dimensiones histórico-sociológicas de la tortura en comisarías de Brasil: el caso Pernambuco
}

\begin{abstract}
todos, vais a ser procesados. Entonces siempre estábamos con ese dilema, salía uno, entraba otro. Y no era de un día para otro. Salía uno entraba el otro. Esa profesora daba clase de sociología y el profesor, de vigilancia en zona rural. Y el profesor tenía tan mal genio que daba miedo, decía, “en las chabolas hay que entrar derrumbándolo todo, rompiéndolo todo, arroyándolo todo. En las áreas nobles no, si hacéis eso os despiden enseguida si trabajáis en Boa Viagem, Espinheiro. Y otra cosa también es la cultura de la gente, no puedes llegar tan delicadamente al Coque, dando buenos días, buenas tardes... porque uno u otro entiende, pero la mayoría allí no lo entiende, no. Desgraciadamente esa es la verdad. En las chabolas es así, ellos sólo entienden a lo bruto. Si hablas educadamente se creen superiores, que la policía les tiene miedo. Que le sacan ventaja a la policía. Entonces, desgraciadamente así es la vida del policía trabajando en las chabolas. (A4). ${ }^{\text {cxxxvi }}$
\end{abstract}

Cuando un profesor criticaba la tortura los alumnos contestaban con mucho énfasis...

¿Y los alumnos, contestaban?

Varios, varios, principalmente los que tenían una formación militar. En esa última Academia, 60\% ya fue PM (Policía Militar). Entonces era incluso unánime. Cuando el instructor hablaba los alumnos que tenían experiencia en las calles lo contradecían inmediatamente. "Eso es porqué tú no estás en la calle para saber cómo funciona esto". Entonces sólo había siempre ese tira y afloja y nunca se llegaba a un denominador común. A mí me parecía importante decir que yo estaba en contra de la tortura, yo estoy en contra de toda y cualquier forma de tortura, pero es necesario que se aborde de forma más profunda este tema porque hay pros y contras. Hay asperezas que tienen que ser limadas. (A1). ${ }^{\text {cxxxvii }}$

En el grupo había opiniones muy diferentes. Algunos estaban a favor, dependiendo del caso. Otros estaban totalmente en contra. (A2). ${ }^{\text {ccxxxviii }}$ 


\title{
Dimensiones histórico-sociológicas de la tortura en comisarías de Brasil: el caso Pernambuco
}

\begin{abstract}
Sobre el papel de la Academia y su influencia para deshacer ideas preconcebidas sobre la tortura, los entrevistados fueron más rotundos que con la pregunta anterior. Para ellos, o la Academia no sirvió de nada o, peor, sirvió para introducir el tema de la tortura, aunque de forma indirecta, como algo normal e inevitable.
\end{abstract}

“Los contenidos vistos durante la Academia servirán para cambiar la idea que ya tenía sobre la tortura?"

No. (CA6). ${ }^{\text {ccxxxix }}$

No. Tales contenidos no ayudaron para nada a formar un concepto, una actitud relativa hacia la tortura. (C4). ${ }^{\text {ccxl }}$

No. En realidad los contenidos se mostraron insuficientes para la teoría y práctica de la investigación dentro del Estado democrático de derecho. Había una preocupación, que era sólo formal, de decir que la tortura era algo ilegal según las leyes de represión actuales. (C2). ${ }^{\text {ccxli }}$

No tanto por los contenidos, pero sí por el ambiente de fuera de las aulas. Yo antes estaba totalmente en contra y comencé a tener una opinión más flexible durante la Academia. (C3). ${ }^{\text {ccxlii }}$

No, al contrario, los profesores valoraban al policía operativo y éste tenía buen concepto de quien obtenía información aunque fuese con tortura. (C13). ${ }^{\text {ccxliii }}$

No. Yo tenía una imagen muy mala sobre la tortura. (C12). ${ }^{\text {cxliv }}$ 


\section{Dimensiones histórico-sociológicas de la tortura en comisarías de Brasil: el caso Pernambuco}

Los agentes, una vez más, fueron más tajantes que los comisarios. Para ellos, la Academia no cumplía su rol, peor, sirvió para introducir el tema de la tortura, aunque de forma indirecta, como algo normal e inevitable.

Las clases marcaban un norte... así es porque post-academia también se nos enseña... Eso es complicado... Administrar información de esa manera porque también se nos enseñaba en otras asignaturas en las que se decía: Tú ahora tienes poder de policía. Entonces los alumnos, ¿Y de que va ese poder de policía? El instructor de forma metódica y didáctica decía. 'Es el poder que el estado te da para en su nombre, Estado y del bien común, disminuir el bien y el derecho de un individuo'. Entonces mira la forma como fue asimilada esa información por varios mundos. Porque cada alumno es un mundo. Cada alumno una realidad. Y esa información llegó a todos los alumnos, la de que ahora estaban investidos con el poder de policía. Entonces estoy yo ahora, alumno, sabiendo que el Estado me dio ese poder, ¿y como usarlo? Maquiavelo decía, los fines justifican los medios (...). (A1). ${ }^{\text {cxlv }}$

No. La academia sirvió más para mostrar la parte positivista del asunto... Fue válida porque los instructores, a pesar de valorizar la parte más legal del asunto, mostraban los riesgos que había de practicar la tortura, perjudicar la carrera o la imagen de la corporación. (A2). ${ }^{\text {ccxlvi }}$

Antes de entrar yo era contra... A veces tenía encontronazos con el profesor y decía no es necesario hacer eso, no... Yo creo que conversando conseguimos muchas cosas... Porque si el informante no es bueno, el delincuente puede morir a palos y no va a decir nada... Yo siempre estuve contra la tortura... Y algunos compañeros decían, ah chaval, el policía tiene que ser bruto, truculento y "astabiriado", un nombre de ese tipo. El policía tiene que ser feo, grande $\mathrm{y}$ fuerte, era aquella imagen de antiguamente. Y cuando fui a trabajar realmente existían aquellos comisarios que daban gritos y pegaban a la gente y yo le decía que aquello no era necesario, que de eso nada tú eres un novato ahí estudiando en la facultad quiere cambiar a la policía. Tiene que ser grosera tiene que pegar...Pero no, joder, voy a salir de esto. Y mi padre, que también era policía, me decía, tenga paciencia hijo mío, estudia y saca otras oposiciones y entonces sales de aquí... (A4). ${ }^{\text {ccxlvii }}$ 


\title{
Dimensiones histórico-sociológicas de la tortura en comisarías de Brasil: el caso Pernambuco
}

\author{
Algunos dejan claro que se volvieron más tolerantes con la tortura después de \\ pasar por la Academia de Policía.
}

¿Podemos decir que usted era más flexible en cuanto al uso de la tortura después de haber pasado por la Academia?

Perfecto. Perfecto, perfecto, porque tal vez sin esa experiencia, incluso para una persona que no pasó por la academia pero que sabe torturar, es crimen. Todo y cualquier crimen de tortura está equivocado tanto del punto de vista legal como del ético. Pero esa dimensión de proteger el bien, la historieta de superman... es complicado... (A1). ${ }^{\text {cxlviii }}$

Sí. $(\mathrm{C} 13){ }^{\text {ccxlix }}$

Al salir de la academia y al inicio de la carrera yo no toleraba la tortura. Mi intención no era la de seguir la carrera policial al principio y no me destacaba trabajando en el área, pues no permitía que policías utilizaran tales métodos y eso generaba descontento entre los subordinados que decían que no podían hacer nada para investigar un crimen frente a las dificultades y falta de estructura. $(\mathrm{C} 12){ }^{\mathrm{ccl}}$

Sobre el ambiente fuera de clase o "currículo oculto" los entrevistados no dejan dudas sobre cómo la tortura era banalizada allí. Es decir, se facilitaba su asimilación por los nuevos integrantes ${ }^{186}$, entre otras cosas porque los que eran militares o policías antes de ingresar en la Policía Civil tienen gran influencia sobre

\footnotetext{
${ }^{186}$ El nuevo policía aprende en la convivencia con los más viejos el modus operandi del trabajo externo. A través de la observación de cómo los policías más viejos actúan delante de nuevas situaciones ellos empiezan a elaborar su concepción de la profesión policial. Es esa experiencia la que va cubrir los vacíos que la teoría no enseña. Pero, principalmente, se posicionarán para alcanzar el respeto de sus colegas de trabajo (WESTLEY, 1970: 189).
} 


\section{Dimensiones histórico-sociológicas de la tortura en comisarías de Brasil: el caso Pernambuco}

los demás ${ }^{187}$. En ese caso no hay ninguna diferencia entre los discursos de comisarios o agentes.

“Y sobre el tratamiento extracurricular, es decir, cómo el tema era tratado fuera de la clase?"

Era tratado como un mal necesario. Había gente que decía: "en ciertos casos no hay opción". (C1). ${ }^{\text {cli }}$

Sin interés. Las personas tenían miedo de comentar. (CA5). ${ }^{\text {clii }}$

Con normalidad, como algo necesario en la práctica, una vez que la práctica dentro de la legalidad no se mostraba eficiente en la práctica. (C2). ${ }^{\text {cliii }}$

Muchas veces yo oía bromas sobre torturas y otras veces oía relatos de casos que eran solucionados con tortura. Pero no había ningún pudor sobre eso. Era como si fuera algo normal, banal. Al contrario, si había algún pudor era el de demostrar que nos oponíamos a la tortura. Era como si eso hiciera parecer que no se nos daría bien ser policías. Los policías más antiguos nos miraban a nosotros, a los jóvenes policías cómo si nos faltara algo, como si no sirviéramos para el trabajo porque éramos muy educados... no sé, como muy legalistas... Era como si no fuésemos policías... Si dijésemos algo contra la tortura entonces sí que pareceríamos extraterrestres. (C3). ${ }^{\text {ccliv }}$

Informalmente charlábamos sobre el tema haciendo referencia a algún caso de crimen con gran repercusión en los medios de comunicación y, en esas ocasiones, algunos alumnos que ya formaban parte de los cuadros de la policía civil - agentes o escribientes - decían que en

187 Un veterano ofrece confianza a sus compañeros porque domina las situaciones. Los guardias tienen una imagen de cada compañero y calculan sus reacciones probables ante una situación de riesgo. Esos valores acentúan el paternalismo y autoridad de los más antiguos sobre los nuevos. La experiencia, el ser "gato viejo", es un escalafón informal de autoridad paralelo a le jerarquía formal. (ROBLES, 1997: 46). 


\section{Dimensiones histórico-sociológicas de la tortura en comisarías de Brasil: el caso Pernambuco}

aquellas investigaciones el "método" utilizado fue el de la tortura. Eso era visto con naturalidad por aquellos alumnos. $(\mathrm{C} 4){ }^{{ }^{\mathrm{cclv}}}$

Las experiencias que nos contaban siempre incluían torturas donde el policía tenía éxito al realizarlas y sólo los perezosos eran los que se conformaban con el testimonio sin tortura. C13). ${ }^{\text {cclvi }}$

Fuera del aula el tema era tratado con críticas en relación a aquellos alumnos que no tenían vocación para ser policías y estaban allí sólo para tener un empleo, sin embargo, los que se decían con vocación siempre trataban la tortura como necesaria. $(\mathrm{C} 12){ }^{\text {cclvii }}$

Es un asunto que para los jóvenes que ingresaban sonaba hasta un poco despectivo. Muchos decían, ¿qué pensáis vosotros de la tortura? 'La madre que lo parió, hay que torturar de verdad... delincuente bueno...tiene que llevarse palos, porque sólo con porrazos se abre...' Entonces, como era así de mecánico por parte del instructor, había esa ligereza por parte del alumno. 'No, tiene que ser con porrazos, porque sólo con porrazos se soluciona...' ¿Te enteras? Nunca hubo una vía para intercambiar experiencias, no sería tanto para intercambiar experiencias, porque experiencia no había. Pero, un canal más abierto, uno “¿por qué crees cree que hay pegarle al delincuente?”. Eso nunca se preguntaba. Sólo se repetía que siendo o no delincuente, no se le podía pegar. (A1). ${ }^{\text {cclviii }}$

Son determinados grupos que se forman dentro de la propia clase, como la tendencia es la de acercarte al grupo con el que más te identificas... Y entonces había grupos que venían de la PM (Policía Militar) y eran favorables al uso de la tortura... Y entonces estaban los más conservadores, que vinieron de cursos de psicología, que eran los que nunca tuvieron experiencia policial callejera en la vida... Entonces la opinión general que prevalecía dentro de mi grupo era la de que dependía de la necesidad según el trabajo. (A2). ${ }^{\text {cclix }}$ 


\section{Dimensiones histórico-sociológicas de la tortura en comisarías de Brasil: el caso Pernambuco}

El contenido fuera de la academia estaba influenciado por los que ya eran policías y decían que allí fuera, sin dar palos, la gente no respetaba a la policía y que sí que había que dar porrazos, la policía daba caña de verdad, en 86 . (A3). ${ }^{\text {cclx }}$

Otra forma de comprender los discursos "ocultos" es observar los chistes más comunes en la Academia.

¿Muchos chistes de tortura?

Sí, mucha gente decía que debería haber asignaturas como tortura 1 , tortura $2 \ldots(\mathrm{C} 12) .{ }^{\text {clxi }}$

Sí, la tortura era vista con una cosa normal, desde que existiera una investigación policial. $(\mathrm{C} 13){ }^{\text {cclxii }}$

Ah, seguro. Por parte de los alumnos siempre sonaba de forma despectiva. Y yo me acuerdo que cuando estaba en la academia fue cuando surgió la legendaria 'Tropa de Élite'. Entonces, después de esa película, dar clase de derechos humanos se volvió más difícil. Se volvió mucho más difícil. El alumno siempre tenía una respuesta que justificaba una posible tortura. $\mathrm{Y}$ demasiados casos que eran presentados por los alumnos de forma sensacionalista: oh, a fulano le dieron una paliza y cantó... (A1) $)^{\text {clxiii }}$

Sin duda. Como había muchos policías militares, entonces cada uno contaba su historia. Entonces, ellos tenían una frase que recuerdo mucho, siempre decían: derechos humanos para los humanos. Si estás lidiando con un delincuente, él no se lo va a pensar dos veces antes de quitarte la vida, no se lo va a pensar dos veces antes de violar a una chica de 14 años. Que no se lo va a pensar dos veces antes de un latrocinio. Entonces esa persona no merecía ser considerada por los derechos humanos porque en mi grupo no era considerada humana. (A2). ${ }^{\text {cclxiv }}$ 


\title{
Dimensiones histórico-sociológicas de la tortura en comisarías de Brasil: el caso Pernambuco
}

\begin{abstract}
Si buscamos comprender porqué se utiliza la tortura como método de investigación necesitamos descubrir la importancia dada a otros métodos de investigación de acuerdo con los principios legales y morales. Y una vez más queda clara la "ineficiencia" de la Academia de Policía en actuar de acuerdo a sus objetivos, pues las técnicas de investigación estaban ausentes de su docencia.
\end{abstract}

“Y cómo las investigaciones eran tratadas en clase? ¿Hubo una buena formación en investigación policial?”

No. Muy superficialmente. Yo hice 45 días de curso. (C1). ${ }^{\text {cllxv }}$

El curso era como de broma. En 45 días de curso yo di cinco disparos con un revólver viejo y nunca tuve una clase que enseñara a investigar. Aprendí todo lo que sé en el día a día. (C3). ${ }^{\text {cllvvi }}$

No. A mí, por lo menos, mi práctica de Academia no me enseñó nada, no. Yo aprendí en el día a día. Y por lo que sé de otras formaciones en otras épocas de Academia, creo que tampoco había eso no. (CA6). ${ }^{\text {cllxvii }}$

No. Los contenidos no tenían el enfoque práctico, no había estudios de caso ni ejercicios prácticos de búsqueda de información y de relacionarla con pruebas técnicas. (C2). ${ }^{\text {cclxviii }}$

No. Lo que se nos decía es que el mejor investigador era aquel que tuviera la mejor red de informantes $(\mathrm{C} 13){ }^{\text {cclxix }}$

Aunque éste sea, desde mi punto de vista, el principal aprendizaje que el policía civil debería tener, no cumplió con mis expectativas. Los principales motivos de este fallo en el proceso de aprendizaje fueron: falta de preparación de los profesores; poca carga horaria para la asignatura; falta de una visión más contemporánea de los métodos de investigación, incluyendo técnicas científicas referentes a la recolección de pruebas. (C4). ${ }^{\text {clxx }}$ 


\title{
Dimensiones histórico-sociológicas de la tortura en comisarías de Brasil: el caso Pernambuco
}

\begin{abstract}
No sé exactamente si era bueno o malo, pero eran los mismos métodos utilizados desde hacía más de treinta años. La Academia se preocupaba más con que los alumnos aprendieran a copiar los procedimientos con que propiamente a buscar una verdad científica para sus investigaciones, inclusive ese era un papel reservado para los Comisarios de Policía y no para los Agentes. (CA5). ${ }^{\text {cllxxi }}$
\end{abstract}

En la academia, como ya he dicho, no hubo ninguna preparación para la vida policial, ya que duró sólo 45 días. $(\mathrm{C} 12)^{\text {cclxxii }}$

Cuando preguntamos sobre el aprendizaje de investigación los agentes son menos críticos que los comisarios.

La formación es buena. Yo la veo como una formación de calidad. Hoy la policía dispone de mecanismos y dispositivos que ayudan en ese proceso investigativo. Sin embargo, yo creo por mi experiencia que la vivencia es lo que te hace un policía bueno o malo. La Academia no tiene influencia para nada en ese aspecto. (A1). ${ }^{\text {cclxxiii }}$

La parte teórica fue satisfactoria. Aunque faltó una parte práctica. No hubo una parte práctica, de casos prácticos, de una investigación policial...Hubo una parte teórica muy rica, pero faltó práctica (A2). ${ }^{\text {cllxxiv }}$

Era muy bueno. Si se siguiese lo que manda la persona, se investigaría mucha cosa...es que hoy en día nadie tiene paciencia, ni tiempo. (A4). ${ }^{\text {cclxxv }}$ 


\section{Dimensiones histórico-sociológicas de la tortura en comisarías de Brasil: el caso Pernambuco}

Es importante subrayar que en ese momento ellos elogian las clases de investigación de la Academia, pero la desvalorizan. Después, cuando son preguntados sobre qué se puede hacer para disminuir la tortura, ellos vuelven a valorar la Academia.

Lo que se puede observar a partir de los entrevistados es que la Academia no actúa de manera eficiente para disuadir a los policías de la práctica de la tortura. Por el contrario, aun cuando no actúa de forma expresa en ese sentido, acaba por favorecer una actitud de aceptación.

En un ambiente donde los nuevos miembros de la corporación quieren parecer totalmente integrados con los veteranos ${ }^{188} \mathrm{y}$, descubriendo que es una práctica corriente en la policía, la Academia, en cuanto no consigue disuadirlos de forma eficiente, acaba por ser un ambiente que favorece la asimilación y ampliación de los comportamientos agresivos.

Es importante subrayar que a falta de un buen aprendizaje académico, el peso de la imitación del día a día pasa a tener un sobrevalor, lo que refuerza la influencia de la cultura corporativa. Considerando el poder informal y la influencia de los veteranos en la formación, preguntamos a los agentes de policía sobre la experiencia práctica, "la experiencia de calle"...

“Cómo fue el aprendizaje diario, en las calles ${ }^{189}$ ? ¿Fue una buena experiencia?"

\footnotetext{
188 "Parte del rito de iniciación consiste en que los/as noveles tienen que luchar por el reconocimiento de sus compañeros antes de ejercer su trabajo con total autonomía. Si se trata de una novicia, la lucha aún es mas dura. El poder informal y la influencia de los veteranos en la formación de los recién llegados es decisiva”. (ROBLES, 1997: 45-46).

189 "La socialización más importante ocurre en la fase de prácticas. Al final de la etapa teórica salen a realizar prácticas vestidos de uniforme bajo la tutoría de un guardia veterano. Se produce entonces lo que Westley llama un reality shock. Hasta ese momento la formación del futuro agente es marcadamente teórica y formalista pero en la calle todo es informal, conflictivo y desordenado. La
} 


\section{Dimensiones histórico-sociológicas de la tortura en comisarías de Brasil: el caso Pernambuco}

De ninguna manera. $(\mathrm{A} 1){ }^{\mathrm{cclxxvi}}$

Los policías con más antigüedad tenían una frase que es típica, tanto en la policía militar como en la civil...ellos te llaman de novatos, que son los policías que se acaban de formar, entonces cuando vas a practicar ellos solían decir: novato olvida todo lo que aprendiste en la Academia, porque aquí en la práctica la policía es otra cosa...lo que has aprendido en la Academia es teoría, pura formalidad, porque la vas a aplicar muy poco. Desgraciadamente, en una buena parte de los casos hasta tenían razón. (A2). ${ }^{\text {clxxvii }}$

Y como. Aprendí que los delincuentes sólo respetan a la policía con un tratamiento que no encaja con los derechos humanos....Aprendí, cuando realmente comencé a trabajar en la Policía que sólo con métodos no convencionales que contrariaban los derechos humanos se conseguía "hacer algo" (tirar serviço), como el sitio donde estaban escondidas armas, drogas...de otra forma no había éxito en el trabajo. Pero en mi caso, yo siempre respetaba los límites para que los policías no exagerasen. $(\mathrm{C} 12){ }^{\text {cclxxviii }}$

Sí, pero a partir de experiencias personales y mucha reflexión. $(\mathrm{C} 13){ }^{\text {cclxxix }}$

No. No es suficiente no. Tenemos que juntar las dos cosas. La información teórica y la parte práctica. Incluso porque a veces tú no conoces la técnica y podrías utilizarla mejor y dejas de obtener más frutos de los que podrías porque no la conoces. (CA6). ${ }^{\text {cclxxx }}$

No. Tú llegas a una comisaría donde eres el jefe máximo y no sabes por dónde va nada. Por suerte hay funcionarios que ya están allí y te van enseñando. Pero también pueden ser muy cabrones al darse cuenta de tu falta de experiencia. A veces ellos se aprovechan para hacer lo que no pueden y a veces se aprovechan para divertirse a tu costa. Hasta que llegar el día en que te sientes seguro, pudo haber mucha mierda por tu falta de preparación. (C3). ${ }^{\text {clxxxi }}$

realidad y sus compañeros veteranos se rigen por dinámicas informales y poco ortodoxa si se comparan con lo aprendido sobre el papel”. (ROBLES, 1997: 45). 


\section{Dimensiones histórico-sociológicas de la tortura en comisarías de Brasil: el caso Pernambuco}

No. Como la deficiencia en la formación es un hecho antiguo, encontré policías que sabían poco acerca de métodos de investigación. La llamada policía científica no disponía de equipos adecuados. Fue necesario invertir en lecturas y cursos específicos. $(\mathrm{C} 4){ }^{\text {cclxxxii }}$

No, pues hay obstáculos que sólo con el conocimiento sistemático y científico es capaz de producir resultados prácticos. $(\mathrm{C} 2){ }^{\text {cclxxxiii }}$

Dentro del universo reservado al papel de la propia policía sí, incluso porque en muchos casos los nuevos agentes eran obligados a "despreciar" el conocimiento formal, teórico y a aprender en la realidad cotidiana con los otros compañeros. En eso claro, no había ninguna participación de la Academia de Policía u otra unidad de recursos humanos. (CA5). ${ }^{\text {cclxxxiv }}$

Al ser preguntados sobre las dificultades para erradicar la tortura ${ }^{190}$, los entrevistados siempre hablan de la deficiencia de la Academia en preparar a los policías para que investiguen y también de la escasez de medios para investigar demasiados delitos. Preguntados sobre cuál sería la solución, todos apuntaron al entrenamiento y una mejor formación en investigación ${ }^{191}$.

Sí. Hay métodos de investigación que permiten recolectar y trabajar con pruebas de forma sistemática (...). Invertir en la formación del policía en métodos de investigación;

$190 \quad$ "Respecto a las dificultades aludidas en el epígrafe se ha destacado un amplio abanico. La negligencia de las instituciones con relación a la denuncia, el miedo por parte de las víctimas, la dificultad en la aplicación de la Ley, la carencia de instrumentos de trabajo y de equipamientos modernos de investigación, la precaria infraestructura, la falta de autonomía de los órganos periciales y la cultura policial, han sido las más destacadas". (SILVA, 2006: 252).

191 "Las dos sugerencias más frecuentes de los que creen que es posible realizar algo para romper con la continuidad de la práctica de la tortura ha sido, por un lado, la educación y la educación en derechos humanos; y, por otro, la formación y capacitación específica de las fuerzas de seguridad. De lo que se deduce que los entrevistados creen en la eficacia pedagógica para el cambio de actitud, de mentalidad, y que este cambio sería el responsable de disminuir dicha práctica". (SILVA, 2006: 261). 


\section{Dimensiones histórico-sociológicas de la tortura en comisarías de Brasil: el caso Pernambuco}

perfeccionar los mecanismos para responsabilizar a los que practican ese crimen; equipar a las unidades policiales, es la llamada policía científica. (C4). ${ }^{\text {cclxxxv }}$

Sí. La meticulosa recolección de vestigios en el local de crimen, con una relación íntima con los profesionales de la policía científica involucrados en la investigación, con un intercambio constante e insistente de información bien direccionada. Además del estudio y práctica de la relación con la naturaleza humana, considerando la inevitable necesidad de recolección de prueba oral, obtenida de testigos, víctimas, sospechosos e informantes. (C2) ${ }^{\text {cllxxxvi }}$

Primero, enseñar a investigar. Segundo, poner los medios necesarios para que pueda ocurrir una investigación. Hoy hay muchos más casos que personal y medios para investigarlos. Cuando hay presión y tú no consigues responder a la demanda, puede ser muy tentador recurrir a la tortura. $(\mathrm{C} 3){ }^{\text {cclxxxvii }}$

Yo creo que en la Academia, ya en la formación, se debería dejar bien claro que la tortura no es una cosa bienvenida. Pero yo creo que aún hay profesores que dejan ver entre líneas, dejan entrever, que es una cosa que debe ser cultivada. Entonces debería estar prohibido que alguien que es adepto a ese tipo de postura pueda enseñar, por ejemplo. Pero eso es muy difícil. Primero, como es una práctica muy corriente tendría que haber una asignatura cuyo principal asunto fuese la tortura, no sé exactamente cuál, pensé en eso ahora y no sé exactamente que asignatura sería posible. Interrogatorio. Dentro de la asignatura de interrogatorio tendría que estar muy claro que ese tema debería ser más evidente. Hoy tenemos la asignatura de derechos humanos en la Academia y yo creo que hasta la asignatura de derechos humanos habla poco del combate a la tortura. Y yo creo que tiene que comenzar en la Academia, lo que creo que es obvio. Y la policía tiene que adoptar patrones, para, por ejemplo, constar en todos los testimonios del imputado, preguntas sobre la tortura. Y tendrían que coger crímenes, yo creo que sería eficiente si Asuntos Internos cogiese aleatoriamente casos in fraganti, interrogatorios policiales de homicidio $\mathbf{y}$ crímenes contra el patrimonio, principalmente de esos dos, y llamar a esas personas, llamar a las víctimas, llamar a los imputados, hacer una investigación sin que necesariamente sea una provocación $\mathrm{Si}$ yo sé que aquel interrogatorio mío, Asuntos Internos puede cogerlo y verificarlo, si ve contradicciones... Porque muchas veces 


\section{Dimensiones histórico-sociológicas de la tortura en comisarías de Brasil: el caso Pernambuco}

contradicciones llevan a creer que hubo tortura. Entonces los interrogatorios no son leídos por Asuntos Internos como forma de prevenir y detectar que hubo tortura en aquel interrogatorio. Entrevistas con los presos. (...) Entonces todo el mundo que pasó por comisaría debería ser entrevistado por un órgano, sea secretaría de salud, de educación, sea la que sea, para ver si se detecta algo. Yo creo que si el comisario sabe que aquel preso va a ser oído en Asuntos Internos aunque él no lo denunciase, aunque la pericia no lo acuse del crimen de tortura, él se lo pensaría dos veces. Yo creo que debería ser por muestreo. Que las comisarías tengan cámaras, no puede haber salas donde las personas se encierren sin ser vistas, sin saber lo que están haciendo, bien iluminadas (...). La estructura física, el cómo las comisarías están construidas, ayuda a disminuir la tortura o ayuda a aumentarla. Formaciones de entre cuatro y cinco años. Seminarios anuales. Yo creo que las asociaciones de comisarios de Brasil, incluso de policías militares, jamás van a colocar en pauta la tortura, incluso comisarios que están contra la tortura no colocan eso en pauta para no disgustar. (C1). ${ }^{\text {cclxxxviii }}$

Facilitar a los policías otras técnicas y formas lícitas de obtener resultados y concienciarlos de que la tortura también los hace criminales. (...) Creo que la lucha contra la tortura no se solucionará en tan sólo una generación. Aún somos una generación que no olvidó la dictadura militar como forma de gobierno, o sea, estamos acostumbrados con el Estado represor, omnipotente. Ciertamente la profesionalización de la policía y la constante renovación de los cuadros policiales contribuirán para que acabe la tortura. Pero como la actividad policial consiste en el uso de la fuerza, siempre habrá necesidad de un monitoreo para que la tortura no sea utilizada. (C13). ${ }^{\text {cclxxxix }}$

La policía debe tener un discurso no sólo de combate a la tortura, sino también de construcción de una nueva misión para la Policía y de un nuevo papel para el policía. Para eso creo que aún estamos a años luz, porque eso sólo podría pasar con la efectiva participación de la sociedad. Y la sociedad aún está interesada en mantener una tolerancia hacia los actos de corrupción y consecuentemente con la tortura. Creo que trabajos de esta naturaleza pueden contribuir por lo menos para que se haga un diagnóstico un poco más realista sobre el tema en las instituciones. (CA5). ${ }^{\text {ccxc }}$ 


\section{Dimensiones histórico-sociológicas de la tortura en comisarías de Brasil: el caso Pernambuco}

Sólo métodos técnicos. Existe también el poder de persuasión. Muchas veces amenazas y palabras hacen que los testigos y los propios investigados "abran el juego", facilitando las investigaciones. Los riesgos de la tortura son grandes para los policías, sin embargo, aquellos que practicaron torturas, digamos leves, siempre se destacaban en relación a aquellos que no torturaban. $(\mathrm{C} 12){ }^{\mathrm{ccxci}}$

Creo que la valorización de la interceptación telefónica como medio de investigación es muy importante en ese sentido. Suministra tantos elementos probatorios que ya no se necesita ninguna confesión, lo que constituye un importante instrumento para cambiar la cultura de la tortura. Pero la interceptación no es el único medio. Es preciso estimular otras formas de investigación que den soporte y complementen el interrogatorio, tales como la vigilancia, la quiebra de sigilo, la búsqueda de otras informaciones contenidas en bases de datos, etc. $(\mathrm{C} 13){ }^{\text {ccxcii }}$

Otro punto que merece destacarse es la importancia que se concede a la confesión. Peters ya llamaba la atención sobre ello en los códigos de proceso penal y tribunales, así como sobre la burocratización de la justicia como un incentivo a la tortura.

Preguntados sobre si se da mucha importancia a la confesión:

Se hace mucho hincapié. Tanto que quién no tortura no se preocupa con quien no confiesa. Es incluso mejor cuando no confiesa porque es uno de los indicadores de que no fue torturado. Y si consigues probar el crimen sin confesión va a tener mucha más credibilidad. Es interesante porque, muchas veces, cuando comienza un interrogatorio en el que tienes pruebas mínimas contra aquella persona, si no confiesa, no sufres ningún estrés. $(\mathrm{C} 1){ }^{\text {cxciii }}$

Sí. Creo que eso es lo más interesante que puede pasar. El sueño de todo investigador. Y ahí ya podemos pasar para el próximo caso. Cuando tienes cien casos que atender, no sobra espacio para ningún romanticismo. Si hay una confesión, es un caso menos. (C3). ${ }^{\text {ccxiv }}$ 


\section{Dimensiones histórico-sociológicas de la tortura en comisarías de Brasil: el caso Pernambuco}

(...) cuando trabajé en las comisarías de la zona rural, todo el trabajo es hecho basado en la confesión, porque no tienes los medios técnicos, y entonces no tienes las pruebas materiales. Entonces en estos sitios, la confesión es imprescindible. Ya en la capital como tienes los recursos, aunque aún no son utilizados de forma satisfactoria, entonces creo que la confesión pasa a ser un tema accesorio. Pero en las comisarías de provincias la confesión es prácticamente $90 \%$ de la investigación. (A2). ${ }^{\text {cxcv }}$

No. No veo importante la confesión. Si el investigador entrega el "servicio" en la base de tortura "aceptable", como por ejemplo el "saco" y consecuentemente se halla el arma del crimen, la droga, no se hace necesaria la confesión. Al fin y al cabo, han sido raros los casos de confesión espontánea, en trece años de policía y de experiencia en el área. $(\mathrm{C} 12) .{ }^{\text {cxcvi }}$

Sí. (C13). ${ }^{\text {ccxcvii }}$

También hablaron los entrevistados del escaso uso de una técnica que viene demostrando ser muy eficiente para la disminución de la tortura, que es el servicio de información (inteligencia policial) y de las escuchas telefónicas. Una vez más se refuerza la idea de que la técnica disuade el recurso a la tortura.

Una técnica que observamos y que incluso ya se está comentando que se debe tener cuidado para que no se vuelva usual, es la "parte de inteligencia" y, principalmente, la interceptación telefónica. Hemos observado que el uso de esa técnica permite que formalices la prueba del crimen y la identificación de la autoría. Existe alguna información sobre quién sería el autor o practicante de determinado crimen, a partir de un determinado caso esa persona pasa a ser investigada usando estas técnicas de interceptación y otras y se llega realmente a tener la prueba y a formalizar la autoría y son realizadas detenciones y por lo que yo sé no se necesita esa práctica. (CA6). ${ }^{\text {ccxcviii }}$ 


\section{Dimensiones histórico-sociológicas de la tortura en comisarías de Brasil: el caso Pernambuco}

He observado que tras la utilización de las escuchas telefónicas hubo un aumento de las investigaciones. Se volvieron más eficientes y los comisarios que las usan en general no recurren a la tortura. Pero aún es poco utilizada. (C3). ${ }^{\text {ccxcix }}$

Da privilegios a los que usan las técnicas de inteligencia. Pon a disposición herramientas de trabajo y metodología. (C2). ${ }^{\mathrm{ccc}}$

Varios, varios. La propia inserción del método de policía comunitaria. Donde la población se vuelve un tercer ojo de la policía. Trabajar con Servicios de información, la propia inteligencia tecnológica de la que hoy disponemos es un medio que ayuda mucho en las investigaciones. Entonces es como que, la propia policía está invirtiendo en esto, en logística y está facilitando bastante el proceso investigativo. A diferencia de los tiempos de mi padre, por ejemplo, en que se sujetaba al tipo y era a base de golpes. Sólo había ese método. Y lo peor es que aún existen vestigios de ese tipo de policía en nuestro medio... Hay policías aún en la activa que fueron del antiguo DOPS (Departamento de Orden Político y Social)... La dictadura fue ayer... Donde sí era lícito torturar... Entonces, ¿cómo sacarle de la cabeza a esos policías que la tortura no da resultados? (...). (A1). ${ }^{\text {ccci }}$

Inteligencia policial. Cuando vas un paso por delante do lo que el delincuente va a hacer. Es el mejor método que la Policía Civil tiene, aunque no pueda abarcar todo el Estado. (A2). ${ }^{\text {ccii }}$

¿Por qué no usarlas?

Falta enseñanza y gestión. Primero porque en la Academia no enseñan las técnicas más necesarias. Segundo porque los gestores no están capacitados para estimular a sus subordinados a emplearlas. $(\mathrm{C} 3) .{ }^{\text {ccciii }}$ 


\section{Dimensiones histórico-sociológicas de la tortura en comisarías de Brasil: el caso Pernambuco}

\subsection{Intolerancia con la tortura}

Cuando los entrevistados fueron preguntados sobre cómo reaccionarían al presenciar, hoy, un acto de tortura, respondieron de modo diferente: dependiendo del caso, aseguraron que se mostrarían indiferentes, o no lo aceptarían, o adoptarían una respuesta moderada. Varios confesaron que dudaban sobre qué harían. Es decir, no cabía esperar una condena unánime.

Es interesante observar cómo los policías se comportan ante una práctica de tortura, o de su perturbación ante de una hipotética práctica. De lo extraído, podemos concluir que quien la practica no tiene que preocuparse mucho con la reacción de sus iguales.

Preguntados los entrevistados sobre la reacción de los policías con otros policías que practican la tortura, dejan claro que hay una tolerancia muy amplia con los torturadores cuando éstos no son considerados "corruptos" o cuando consiguen buenos resultados. Es como si hubiera una esquizofrenia frente a la tortura, "no", pero "sî".

¿Y cuál fue la reacción al presenciar la tortura?”

Me sentía mal, el comisario terminó teniendo (esa postura), eso fue antes de la CF 88 (Constitución Federal del 88), yo era de opinión minoritaria, algunos también se sentían molestos porque... principalmente cuando se agredía a un tipo que no había cometido ningún crimen. $\mathrm{O}$ sea, si hubiera cometido algún crimen aún era justificable, la paliza, ese era el pensamiento dominante de la policía en aquella época. Y yo me sentía muy mal con su presencia inclusive, con estas actitudes. El ciudadano venía a poner una queja, una denuncia 


\section{Dimensiones histórico-sociológicas de la tortura en comisarías de Brasil: el caso Pernambuco}

(BO- Boletim de Ocorrência), y ya hubo algún ciudadano al que le dieron una paliza allí. (C1). ${ }^{\text {ccciv }}$

Yo me sentí muy mal, pero no quería que los policías milites se dieran cuenta y creyeran que yo era débil o que no tenía valor para ser policía. Fingí que era la cosa más normal del mundo, conversé con el oficial del asunto que tenía para tratar con él, además pregunté si el preso había vomitado alguna cosa (dado alguna información) para parecer lo más tranquilo posible. (C3). ${ }^{\mathrm{ccc} v}$

Buscan estar ausentes en la práctica, muestran malestar al tener que admitirla. (C2). ${ }^{\text {ccvi }}$

Nunca lo presencié no. Yo realmente creo que nunca quise pensar en eso no. Pero así, yo creo que voy a intentar impedir que eso pase... y sinceramente no sé qué pasaría, si yo iría a formalizar aquello para que fuera investigado, no sé, iba a depender de la situación creo, realmente no sé. (CA6). ${ }^{\text {cccvii }}$

Interferiría seguramente y, como no confío en las unidades de inspección internas, pondría una denuncia a la Fiscalía (CA5). ${ }^{\text {cccviii }}$

Dependiendo del caso, por la realidad que vivimos, lo vería con cierta normalidad, pero con la seguridad de que no podría eximirme de la responsabilidad penal. (C2). ${ }^{\text {cccix }}$

Si fuera practicado por un subordinado mío no lo permitiría. Si fuera practicado por un compañero comisario, no se lo aconsejaría. (C4). ${ }^{\text {cccx }}$

Yo ya lo presencié y no me gustó. Hoy reacciono muchas veces e intento contener a los agentes para que no actúen con excesos, sin embargo, muchas veces siento que es necesario, desafortunadamente. Pero intento siempre sentir si aquella persona realmente se merece aquello, si tiene antecedentes o si estoy seguro de que cometió el crimen. $(\mathrm{C} 12){ }^{\text {cccxi }}$

Hoy, en el ambiente en el que trabajo yo me declaro abiertamente contra la tortura... Mira, hoy estoy en contra de toda y cualquier tipo de tortura. Pero recientemente ha ocurrido un 


\section{Dimensiones histórico-sociológicas de la tortura en comisarías de Brasil: el caso Pernambuco}

crimen de gran complejidad, involucrando, en un lugar desierto, un homicidio y una violación, y la única víctima era la persona violada. Y de la única cosa de la que ella se acordaba era de pequeñas características del acusado, algunos tatuajes. Y salimos en busca del acusado hasta que lo encontramos. ¿Cómo solucionar esto? ¿Y cómo actuar sabiendo con tanta seguridad que era él? Evidentemente él no iba a confesar. Y hubo tortura y él confesó, dando detalles. Tanto que la tortura ocurrió en el local de los hechos. Y él confesó bajo acción de tortura. Y yo estoy seguro de que si no hubiera sido hecho así él no habría hablado. (...). Lo que yo creo... la tortura es un crimen y como todo crimen, tiene sus excepciones (...) yo creo en los casos en que... es complicado porque todo depende del caso concreto... Existen situaciones en que se necesita de la materialidad del crimen y en el caso del... Pero volviendo a la respuesta yo estoy en contra y abiertamente en contra a toda forma de tortura. No hay más tortura delante de mí... es complicado... en fin, particularmente, yo creo que en los casos en que yo pensara que iría a necesitar mucho, creer que si tenía aquella información... y así pudiera obtener aquella información, yo torturaría sin ningún problema. (A1). ${ }^{\text {ccxii }}$

\section{“Y cuál sería la reacción al volver a presenciar la tortura?”}

Yo no lo encubriría. No participaría no. Tampoco denunciaría, ni daría consejos. No vi nada, no vi nada, no vi nada, no sé de nada. (A3). ${ }^{\text {cccxiii }}$

No sé.....No sé.... (C3). ${ }^{\text {cccxiv }}$

Si fuera posible evitarlo, es eso lo que haría. También podría investigar e intentar castigar a los policías que actuasen de ese modo. (C13). ${ }^{\text {ccxv }}$

(...) hoy, es muy complicado esto, cuando tú, hoy en día, yo tomaría una actitud, con más experiencia, más maduro, incluso a esa edad, sabiendo lo que sé hoy, no trabajaría más en ese lugar, por ejemplo. Pero en aquella época, no hice eso, el comisario estaba enterado y no le molestaba y nosotros veíamos que ese tipo era muy desequilibrado, más de lo normal, (C1). ${ }^{\text {cccxvi }}$ 


\section{Dimensiones histórico-sociológicas de la tortura en comisarías de Brasil: el caso Pernambuco}

La mayoría de ellos no tortura, pero la ignora, ya que muchos agentes afirman que no existe otra forma de investigar determinados crímenes, convenciendo así al comisario, pues este siempre quiere tener éxito en sus investigaciones y desafortunadamente tiene que someterse a tales métodos. $(\mathrm{C} 12){ }^{\text {cccxvii }}$

Afortunadamente, hoy prevalecen los comisarios legalistas, que no toleran la tortura. Los agentes suelen actuar en consonancia con la orientación del comisario, entonces, la tortura disminuyó bastante. $(\mathrm{C} 13) .{ }^{\text {cccxviii }}$

A4 hace mención a la posición de inferioridad que tiene un policía novato, pese a decir que ahora "a gente tem o direito de falar mais alto":

Hoy que tenemos el derecho a hablar más alto y yo digo no hagas eso no que vas a ser castigado. Voy a comunicarlo, voy a escribirlo, voy a poner una denuncia. No admito que se haga eso donde trabajo. La primera cosa que digo es que no admito violencia. La PM (Policía Militar) también llega con toda su violencia y yo digo no vamos a hacer eso no, porque hoy todo el mundo tiene una cámara en el móvil, tiene los derechos humanos y nos va a salpicar. Entonces reducen la violencia. (A4). ${ }^{\text {cccxix }}$

¿En los últimos cinco años necesitó decir eso a alguien?

Necesité. En la civil y en la militar. ${ }^{\text {cccxx }}$

¿Y en los últimos dos años?

Necesité. Y en el último año también. (A4). ${ }^{\text {cccxxi }}$ 


\section{Dimensiones histórico-sociológicas de la tortura en comisarías de Brasil: el caso Pernambuco}

Ninguno de los entrevistados dudó en admitir que hay tolerancia con la tortura en la policía.

¿Crees que hay tolerancia en la policía con la tortura?”

Se condena mucho más la corrupción que la tortura. La tortura, a veces, es hasta tolerada cuando, digamos, hay un policía que tortura, pero que las personas lo tienen como no corrupto. Hasta es soportada. Como yo, que conozco a un comisario de policía que las personas lo sabían, bromeaba en público, y, como que lo toleraban, después yo supe que ciertos actos que él hacía, cualquier psiquiatra, cualquier persona consciente iría a considerarlos como una cosa de enfermedad mental (refiriéndose al entrevistado C10). Y no es cien por cien verdad que no fuera corrupto también, pero tenía esa apariencia de ser sólo torturador. (....). (C1). ${ }^{\text {cccxxii }}$

Sí. (C2). ${ }^{\text {cccxxiii }}$

Sí, de forma velada. (C4). ${ }^{\text {cccxiv }}$

Sin duda. Todos a los que conozco, conocen algún caso de tortura y nunca vi una reacción indignada o algún movimiento para extinguirla. Si eso no es tolerancia, yo no sé lo que es. (C3). ${ }^{\text {cccxxv }}$

Evidentemente. (CA5). ${ }^{\text {ccxxvi }}$

Hoy en día anda disminuyendo con la existencia de métodos modernos de investigación, como la interceptación telefónica. Sin embargo, frente a las dificultades de la judicatura para analizar o por tardar en analizar, las pruebas pueden desparecer y la única forma de hacer que eso no pase es utilizar los métodos ilegales. (C12). cccxxvii $^{\text {con }}$ 


\section{Dimensiones histórico-sociológicas de la tortura en comisarías de Brasil: el caso Pernambuco}

Aún hay tolerancia, a pesar de haber disminuido significativamente en los últimos diez años. (C13). ${ }^{\text {cccxxviii }}$

Existe. Existe sí. Yo creo que en la institución es lícita la tortura, desde que no sea descubierta. Hoy existe una dinámica de la institución por la búsqueda incesante de resultados. La institución quiere resultados, la institución quiere autoría, quiere materialidad. Lógicamente está en contra de la tortura, castiga a los torturadores, eso es evidente, como una institución legal, castiga, pero como te dice que "quiere esos resultados para ayer", y no te da recursos, implícitamente, tácitamente, te está dando un aval para torturar, con una pega: mira, quien coge la bomba eres tú. Y a veces el torturador es un torturado porque la tortura está no en la tortura física, pero en aquella tortura psicológica porque yo tengo una autoridad, y para preservar esa autoridad, ese plus, yo tengo que dar resultados... (A1). ${ }^{\text {ccxxix }}$

Yo creo que hay. Porque existe una total, total, búsqueda del resultado. Hoy la PC (Policía Civil) Pernambuco quiere el resultado y muchas veces a nadie le importa como ese resultado será obtenido. Tú simplemente llegas a un subordinado y dices yo quiero determinado resultado mañana $\mathrm{Y}$ dices, pero no tengo las condiciones que necesito... Búscate la vida, pero yo quiero ese resultado mañana... Entonces hoy yo creo que la Policía Civil es fanática por números. La Policía Civil no está preocupada con la calidad de sus servicios, ni como está el policía, ni lo que él necesita... Se preocupa de, si hubo 5 homicidios en aquel área yo quiero 5 homicidios solucionados... Si tú dices yo tengo el resultado, ella no quiere saber cómo se obtuvo el resultado... Entonces mándame eso que vamos a alimentar una plantilla, que va a alimentar una plantilla, que va a alimentar tal plantilla que va a llegar al Gobernador... Entonces, hoy yo creo que indirectamente la propia Policía Civil no sólo está influenciando, como incentivando la práctica de la tortura... Como mínimo está haciendo caso omiso al no preocuparse por como los policías están llegando a tales resultados. (A2). ${ }^{\text {cccxxx }}$

Parece haber más tolerancia corporativa con quien practica la tortura que con quien no la practica. Y todo parece depender de la razón por la que se practica. De lo extraído en las entrevistas parece que quien es incapaz de practicarla será considerado como un mal policía, débil, "legalista", incapaz para el trabajo. Y quien 


\section{Dimensiones histórico-sociológicas de la tortura en comisarías de Brasil: el caso Pernambuco}

tortura, a menos que sea un psicópata o un corrupto, será visto como un policía diligente, trabajador, etc. ${ }^{192}$.

CA6, al referirse a un comisario que ella ya había calificado antes de "psicópata", relativiza diciendo:

Él es una persona muy extrovertida, hace amistad con mucha facilidad y es una persona divertida... Entonces, aunque se tenga conocimiento de esas prácticas suyas, él no es rechazado, él es una persona divertida, es una persona... es por ahí. (CA6 refiriéndose al entrevistado. (C10). ${ }^{\text {cccxxxi }}$

C4 se refiere a la obtención de resultados como un atenuante de la tortura y CA5 habla de los "falsos discursos" condenatorios de dicha práctica.

Si son de jerarquía superior a la del comisario torturador, lo ignoran, desde que se obtenga el resultado. Tal conducta incluso estimula la práctica de la tortura. Si son del mismo grado jerárquico, sólo se dan por enterados. (C4). ${ }^{\text {cccxxxii }}$

192 Paixão, estudiando la organización policial, percibió una autorreferencia de los policías civiles como "basureros de la sociedad". "Ser 'basurero de la sociedad' implica la protección de la sociedad contra el residuo marginal, la 'escoria' y, prácticamente, esta protección significa la imposición autoritaria de valores céntricos en la "periferia social"' (Paixão, 1982: 80). Kant de Lima llegó a resultados muy similares. Tratando de la cultura policial, el autor sugiere que hay en la policía la presencia de una visión evolutiva de la sociedad en la que las clases populares pertenecen a un nivel inferior, la violencia es lenguaje corriente y los códigos jurídicos de castigo no se aplican. "Cuando los litigantes son de estatus social bajo, la violencia es asumida por la policía como parte integrante del cotidiano de estas personas. Para adecuarse a esos patrones, la policía aplica un código que juzga esas 'agresiones' de forma diferente, legitimando, a la vez, el uso que ella hace, eventualmente, de la violencia contra esos segmentos de la población: "Ese es el único lenguaje que esta gente entiende", (1998: 77). (FERREIRA, 2002: 131). 


\section{Dimensiones histórico-sociológicas de la tortura en comisarías de Brasil: el caso Pernambuco}

En general toleran con algún límite. Ellos manejan ese límite, pero tienen el discurso de evitar la violencia. (CA5). ${ }^{\text {cccxxxiii }}$

C1 y C3 hacen referencia a la corrupción como la zona limítrofe entre la aceptación o la condena.

Cuando es sólo torturador él tiene una aceptación mucho mayor. Fulano hace eso, pero fulano es trabajador, pone mucho empeño. Mucho más grave que hurtar es el crimen de torturar para descubrir la autoría del crimen. $(\mathrm{C} 1){ }^{\text {cccxxiv }}$

En general yo no pienso en eso. No hablamos sobre eso. Hablamos cuando el policía es corrupto, pero no comentamos cuando tortura eventualmente. Es como si fuera un mal menor. A menos que sea un psicópata o un sádico... (C3). ${ }^{\text {cccxxxv }}$

“Vio que algún policía fuera rechazado por no admitir la tortura bajo ningún supuesto?"

Sí, incluso despedido de los cuadros por no acatar órdenes superiores. (CA5). ${ }^{\text {cccxxxvi }}$

Sí. Fue visto como policía débil y poco práctico. Ineficiente. $(\mathrm{C} 2){ }^{{ }^{c c c x x x v i i}}$

Ellos inclusive, posteriormente me apodaron de "corta rollos" (empata foda), el comisario que está en contra de la tortura es visto por sus subordinados como un "corta rollos" (empata foda), es aquel que, es una cosa muy... aparentemente una broma de mal gusto, pero es muy seria porque el tío está diciendo que tiene placer, porque el joder (a foda) que conocemos es una cosa placentera y quién nos impide joder está impidiéndonos que tengamos placer. 


\section{Dimensiones histórico-sociológicas de la tortura en comisarías de Brasil: el caso Pernambuco}

Entonces quién impide la tortura impide la jodienda (a foda) es un corta rollos del crimen (empata crime). Corta rollos sufrimiento (Empata sofrimento). (C1). ${ }^{\text {cccxxxviii }}$

Ya sí. Los policías mejores, como dije, rechazan a los policías considerados como "miedosos", diciendo que ellos no quieren trabajar o no saben ser policías y sé también que la mayoría no tortura por miedo a responder a procesos, pues muchos están buscando nuevas carreras. (C12). ${ }^{\text {cccxxxix }}$

Nunca vi una represalia expresa, pero tácitamente era muy común que los policías se refirieran a ese policía cómo vago solamente porque él no estaba de acuerdo con la tortura. $(\mathrm{C} 13){ }^{\operatorname{cccxl}}$

Efectivamente rechazado... no lo sé. Realmente él es señalado ¿vale? como muy legalista ${ }^{193}$, muy correcto, son términos que usan para identificarlos. Pero yo creo que eso no es una forma de avergonzar a nadie no. (CA6). ${ }^{\text {cccxli }}$

Rechazado no. Pero ya vi ser tachado de radical o legalista. Un tío poco flexible, que no sabe esquivar las situaciones... (C3). ${ }^{\text {cccxlii }}$

Ya vi en la PM (Policía Militar)... En la Civil, no. (A1). ${ }^{\text {cccxliii }}$

Varias veces, varias veces, tanto en la policía civil, cuánto en la PM (Policía Militar). Cuando entras en un destacamento el más antiguo dice, es lo siguiente, es VOC: ver, oír, callar. Lo que ves aquí, se queda aquí. Si no te adaptas a esto di que yo te voy a poner a hacer guardia en la cárcel, en una cárcel que está con el techo cayéndose sobre tu cabeza; si no tienes estómago para trabajar de esta forma te voy a poner a trabajar en una permanencia; no te vas a quedar en el coche. O tienes el perfil para quedarte en un coche o no lo tienes. Y hoy voy a decir una cosa, como mínimo, a pesar de toda esa cultura de derechos humanos, más del 50\% de nuestro efectivo usaría la fuerza si fuese necesario. (A2). ${ }^{\text {ccxliv }}$

193 Las estructuras discursivas controladas por esa categoría global son por ejemplo el uso de pronombres deícticos de grupo, como nosotros y ellos, típicamente en discursos ideológicos de "ingroups vs. outgroups", y en el uso de pronombres por organizaciones y empresas. (DIJK, 2001: 76). 


\section{Dimensiones histórico-sociológicas de la tortura en comisarías de Brasil: el caso Pernambuco}

Ya, ya vi. Cambiaban de comisaría, decían, oye tú no sirves para el trabajo no, tú eres muy tranquilo, una chica, vete a la oficina, a buscar un trabajo administrativo. (A4). ${ }^{\text {cccxlv }}$

Ya, ya... Pocos... porque en su mayoría practicaba (la tortura). Esos pocos no se mezclaban, eran considerados unos blandengues, un tipo que en vez de ayudar estorba, perjudica el trabajo de la policía, no es policía. Vete a ser profesor de ballet. Vete a otro lugar, no aquí a la policía. Tu perfil no es de policía. Has venido al lugar equivocado. Ve a la escuela a enseñar... era completamente excluido. (A3). ${ }^{\text {cccllvi }}$

¿Cuáles son las consecuencias para quien intenta denunciar?

Depende, cada caso es un caso, digamos. En ese momento en que no hubo acción nuestra existía toda la cultura policial de que aquello era una cosa correcta. Sólo de decir que aquello estaba mal no tenías ni a donde ir. (...).El grupo en general, no sólo de aquella unidad. Eso también porque también había esa cuestión de que las personas que cometían el crimen eran del mismo nivel jerárquico, eran subordinados. Tanto los que observaban el crimen como quién lo practicaba. Ahí queda más difícil la intromisión, tú tienes que tomar la medida radical de salir, abandonar el servicio y buscar al día siguiente el sector y decir porque quieres salir de allí. (...). (C1). ${ }^{\text {cccxlvii }}$

Si hubieras sido un policía bien visto por los demás después pasarías a ser un traidor de la noche al día. Va a parecer que fuiste tú el que cometió un crimen. (C3). ${ }^{\text {ccxlviii }}$

“Crees que es necesario ser condescendiente con esa práctica para no tener problemas con los demás compañeros de trabajo?" 


\section{Dimensiones histórico-sociológicas de la tortura en comisarías de Brasil: el caso Pernambuco}

Sí. No con tus subordinados, pues llegas y dices yo no acepto esto y los que sólo sepan trabajar así que se muden a otra comisaría o que se atengan a las consecuencias. Está solucionado. Pero con los otros es diferente. Si llegas a un grupo donde alguien está divirtiéndolos contando como torturó a un criminal y tú dices que no toleras ese tipo de broma o práctica, van a pensar: está loco, pesado, inconveniente, cualquier cosa desagradable. Si entras en una comisaría y ves que están torturando e intentas impedirlo o vas a Asuntos Internos a denunciarlo, vas a ser muy mal tratado por tus colegas. (C3). ${ }^{\text {ccxlix }}$

De cierta manera. $(\mathrm{C} 2){ }^{\mathrm{cccl}}$

Creo que hace algún tiempo, dependiendo de tu función ese tipo de problema podría ocurrir. Pero ha disminuido bastante ese tipo de ocurrencia. $(\mathrm{C} 13)$ cccli $^{\text {ch }}$

Muchos lo son, incluso yo. Muchos policías dicen: quieres que se descubra dónde está el arma, la droga, entonces no hay otra forma, "suelta"... (C12). ${ }^{\text {cclii }}$

Yo nunca voy a ser permisivo con esa práctica no... hay algunos lugares donde dicen que pasa ese tipo de situación, que aquellos crímenes investigados allí solamente son solucionados mediante ese tipo de práctica... Pero, mi recelo de ir allá no es porque tal vez tuviese que practicar eso, porque yo no iría a hacerlo, vale, pero es por los policías que iría a encontrar allí, porque no sé si yo tendría autorización para echarlos a todos, para poder trabajar con quien yo quisiese. (CA6). ${ }^{\text {ccliii }}$

Mira. En mi presencia no se hace. Si lo están haciendo allí y yo lo sé, tampoco voy allá (...) porque yo creo que si alguien lo está haciendo allí es porque busca algún resultado, si alguien lo está haciendo es porque alguien lo autorizó, entonces es una red muy grande en la que yo particularmente no me meto (...). (A1). ${ }^{\text {ccliv }}$

No. No es necesario que actúes de esa forma, pero es necesario que busques tu espacio. Porque la policía es como una gran familia, vas a tener un espacio si lo buscas y haces por merecerlo. Hay equipos que trabajan sólo con tortura, hay, tanto en la PM (Policía Militar) como en la Civil, si tú no encajas en aquello cabe a ti buscarte el lugar donde encajas mejor para trabajar y vas a ser respetado por eso. Lo que pasa mucho en la PM (Policía Militar) y 


\section{Dimensiones histórico-sociológicas de la tortura en comisarías de Brasil: el caso Pernambuco}

un poco en la Civil es si intentas ocupar un espacio que no te corresponde. Tú quieres trabajar en un destacamento callejero y no tienes estómago para eso, pero quieres, te parece bonito estar en un coche, pero el grupo no te va a aceptar. Si mantienes el vínculo de amistad con ese grupo, pero sabes que te identificas más con un trabajo burocrático, ese grupo que trabaja en la calle va a respetarte. Hoy en día la mejor forma, y lo que más ocurre es que finjas que no ves. Porque si empiezas a meterte en ese trabajo, como está pasando, vas a ser considerado un chivato, aquel que en cualquier momento puede entregar al compañero a Asuntos Internos. Entonces, hoy, en la práctica, lo ignoras. O lo ignoras o cambias de lugar. (A2). ${ }^{\text {cclv }}$

Eso, exactamente, finges que no estás viendo nada, miras hacia otro lado. (A4). ${ }^{\text {cclvi }}$

Nunca. A mí no importa tener o no tener problemas con colegas de trabajo. Nunca fui tolerante con prácticas ni corruptas ni violentas. Las dos son de igual gravedad. (CA5). ${ }^{\text {cclvii }}$

No. (C4). ${ }^{\text {ccclviii }}$

¿Crees que no practicar puede disminuir su autoridad como jefe?

Ya lo hice, cuando vi que la persona que comenzaba a ser torturada no tenía nada que ver con el crimen y ellos me respetaron, como siempre respetan. $(\mathrm{C} 12){ }^{{ }^{c c c l i x}}$

Creo que no. (C13). ${ }^{\text {ccclx }}$ 
Dimensiones histórico-sociológicas de la tortura en comisarías de Brasil: el caso Pernambuco

\subsection{Asuntos Internos}

Usamos los gráficos producidos por Passos (2010) respecto a la contabilización de los delitos de tortura en la Corregedoria de Polícia de Pernambuco, el equivalente a Asuntos Internos en España. La idea era comparar una práctica tan común, según los discursos de los policías, con los números de policías punidos por tal práctica.

Despido de policías civis de la Secretaria de Defensa Social de Pernambuco ${ }^{194}$

\begin{tabular}{|c|c|c|c|c|}
\hline Demissões de Civis - Tipos & $\mathbf{2 0 0 7}$ & $\mathbf{2 0 0 8}$ & $\mathbf{2 0 0 9}$ & $\mathbf{2 0 1 0}$ \\
\hline Homicídio & 5 & 2 & 0 & 2 \\
\hline Abandono de cargo & 5 & 0 & 0 & 1 \\
\hline Concussão & 3 & 3 & 0 & 3 \\
\hline Tortura & 0 & 2 & 0 & 0 \\
\hline Tentativa de homicídio & 1 & 1 & 1 & 0 \\
\hline Estelionato & 0 & 1 & 0 & 0 \\
\hline Roubo & 0 & 1 & 0 & 0 \\
\hline Acumulação de cargo & 1 & 0 & 0 & 0 \\
\hline Peculato & 0 & 1 & 0 & 0 \\
\hline Ameaça & 1 & 0 & 0 & 0 \\
\hline Corrupção passiva & 1 & 0 & 0 & 0 \\
\hline Dano ao patrimônio & 1 & 2 & 0 & 0 \\
\hline Tráfico de drogas & 19 & 13 & 1 & 6 \\
\hline
\end{tabular}

194 Fonte: Departamento de Correição e Estatística da Corregedoria Geral/SDS. 


\section{Dimensiones histórico-sociológicas de la tortura en comisarías de Brasil: el caso Pernambuco}

Como se puede ver en el gráfico, en cuatro años de actividad de asuntos internos, sólo dos hombres de la Polícia Civil, una corporación con más de 5.000 hombres y mujeres, fueron dimitidos por la práctica de tortura. Según el grafico hubo más policía civil dimitido por tráfico de drogas que por tortura. Es difícil creer que un delito tan reconocido en los discursos de los policías sea tan poco denunciado e investigado por el departamento de asuntos internos ${ }^{195}$.

También es muy extraño el bajo número de policías denunciados en la Corregedoria de Polícia de Pernambuco. En dos años, véase gráfico abajo, sólo diez policías civiles fueron denunciados.

Policías denunciados por los crímenes de tortura en los años 2007 y 2008

\begin{tabular}{|c|c|c|c|c|c|c|}
\hline Polícia & Ano & Local & Tipo & Proced & Ano & Vítima \\
\hline PM & 2001 & $\begin{array}{c}\text { Não } \\
\text { informado }\end{array}$ & Não informado & SAD & 2007 & Menor \\
\hline $\mathrm{PC}$ & 2006 & Delegacia & Não informado & SAD & 2007 & Homem \\
\hline $\mathrm{PC}$ & 2006 & Delegacia & $\begin{array}{l}\text { - Ameaça com } \\
\text { arma; } \\
\text { - Aprisionamento } \\
\text { em mala do carro; } \\
\text {-Espancamento. }\end{array}$ & SAD & 2007 & Homem \\
\hline $\mathrm{PC}$ & 2005 & Delegacia & - Espancamento & SAD & 2007 & Homem \\
\hline
\end{tabular}

195 "De acordo com os dados obtidos observa-se que entre os anos de 2007 e 2010 (tabelas 2 e 3), num universo 207 (duzentas e sete) exclusões/demissões, apenas 02 (dois) servidores da Secretaria de Defesa Social de Pernambuco foram demitidos com base no crime de tortura, o que confirma o problema na tipificação de tal delito e a consequente dificuldade de erradicação dessa conduta nos organismos de segurança pública em nosso Estado”. (PASSOS, 2010: 33). 


\section{Dimensiones histórico-sociológicas de la tortura en comisarías de Brasil: el caso Pernambuco}

\begin{tabular}{|c|c|c|c|c|c|c|}
\hline $\mathrm{PC}$ & 2005 & Delegacia & $\begin{array}{l}\text {-Espancamento } \\
\text { seguido de } \\
\text { chibatadas nos pés }\end{array}$ & SAD & 2007 & Homem \\
\hline PM & 2008 & Rua & - Espancamento & SAD & 2008 & Menor \\
\hline PM & 2007 & Rua & - Espancamento & SAD & 2008 & Homem \\
\hline ASP & 2006 & Penitenciária & - Espancamento & SAD & 2008 & Mulher \\
\hline $\mathrm{PC}$ & 2004 & Delegacia & $\begin{array}{l}\text { - Sufocamento; } \\
\text { - Aprisionamento } \\
\text { em mala do carro; } \\
\text { - Espancamento. }\end{array}$ & SAD & 2008 & Homem \\
\hline $\mathrm{PC}$ & 2004 & Delegacia & - Espancamento & SAD & 2008 & Homem \\
\hline PM & 2005 & Residência & - Espancamento & $\mathrm{CD}$ & 2007 & Homem \\
\hline PM & 2007 & Rua & $\begin{array}{l}\text { - Espancamento; } \\
\text { - Aprisionamento } \\
\text { em mala do carro; }\end{array}$ & $\mathrm{CD}$ & 2007 & Homem \\
\hline PM & 2007 & Rua & - Seqüestro & $\mathrm{CD}$ & 2007 & Homem \\
\hline PM & 2007 & Rua & $\begin{array}{l}\text { - Espancamento; } \\
\text { - Extorsão. }\end{array}$ & $\mathrm{CD}$ & 2007 & Homem \\
\hline $\mathrm{PC}$ & 1992 & Rua & $\begin{array}{l}\text { - Choques } \\
\text { elétricos }\end{array}$ & PAD & 2007 & Homem \\
\hline $\mathrm{PC}$ & 2006 & Delegacia & $\begin{array}{l}\text { - Espancamento; } \\
\text { - Seqüiestro. }\end{array}$ & PAD & 2007 & Homem \\
\hline
\end{tabular}




\section{Dimensiones histórico-sociológicas de la tortura en comisarías de Brasil: el caso Pernambuco}

\begin{tabular}{|c|c|c|c|c|c|c|}
\hline $\mathrm{PC}$ & 2006 & Delegacia & $\begin{array}{l}\text { - Espancamento; } \\
\text { - Seqüiestro. }\end{array}$ & PAD & 2007 & Homem \\
\hline PC & 2006 & Delegacia & $\begin{array}{l}\text { - Espancamento; } \\
\text { - Sufocamento; } \\
\text { - Choques } \\
\text { Elétricos } \\
\text { - Outros. }\end{array}$ & PAD & 2008 & Homem \\
\hline
\end{tabular}

Fonte: Departamento de Correição e Estatística da Corregedoria Geral/SDS.

Legenda: SAD (Sindicância Administrativa); CD (Conselho de Disciplina); PAD (Procedimento Administrativo Disciplinar); PM (Policial Militar); PC (Policial Civil); ASP (Agente de Segurança Penitenciária).

No hay un número razonable de punidos para una práctica tan común. Podemos pensar en algunas posibilidades que justifiquen la cifra modesta: a) puede ser fruto de un desvío de denuncias: las víctimas, por ignorancia, buscan comisarías para hacer la denuncia y no la presenta a Asuntos Internos; b) el miedo de sufrir daños más grandes por denunciar a un policía; c) el corporativismo ${ }^{196}$ de los policías que dificultan el registro de denuncias contra sus colegas de trabajo.

Otro punto que merece destaque es el hecho de que el policía que trabaja en Asuntos Internos forme parte de la misma corporación que el investigado. Es decir,

196 "É importante observar que as unidades de investigação interna, ou corregedorias, compõem-se de integrantes dos mesmos órgãos sob investigação. Muitos integrantes das corregedorias eventualmente retomam suas funções habituais na polícia, às vezes para trabalhar ao lado daqueles que investigaram". (ANISTIA INTERNACIONAL, 2001: 53-54). 


\section{Dimensiones histórico-sociológicas de la tortura en comisarías de Brasil: el caso Pernambuco}

el policía de AI que hace una investigación hoy puede, mañana, trabajar e incluso estar bajo el mando de quien él investigaba.

Hay otro número que parece muy extraño. En las entrevistas con policías civiles que venían originalmente de la Policía Militar todos eran unánimes en afirmar que en la PM ellos practicaban y asistían a muchas más torturas que en la Polícia Civil, pero en el gráfico vemos, por el contrario, 10 casos de la PC y 7 de la PM. Hay tres consideraciones importantes: la PM tiene tres veces más número de policías que la PC; la PM hace un trabajo de calle y por eso es la primera a intervenir tornándose más sujeta a situaciones de conflicto con las víctimas de la tortura; el nivel de estudios es menor entre los policía militares (véase Almeida, 2007 - el bajo nivel de estudios genera mayor tolerancia con la tortura); por eso nos parece más fiable la versión de los entrevistados que la información del gráfico.

Volviendo a los policías civiles, otra información que llama la atención es la referente al local donde se practica la tortura. De los diez casos de tortura practicada por policías civiles, nueve tuvieron lugar en la comisaría.

\begin{tabular}{|c|c|}
\hline LOCAL DO CRIME $^{197}$ & QTD \\
\hline Delegacia & 09 \\
\hline Rua & 06 \\
\hline Penitenciária & 01 \\
\hline Residência & 01 \\
\hline
\end{tabular}

197 Fonte: Departamento de Correição e Estatística da Corregedoria Geral/SDS. 
Dimensiones histórico-sociológicas de la tortura en comisarías de Brasil:

el caso Pernambuco

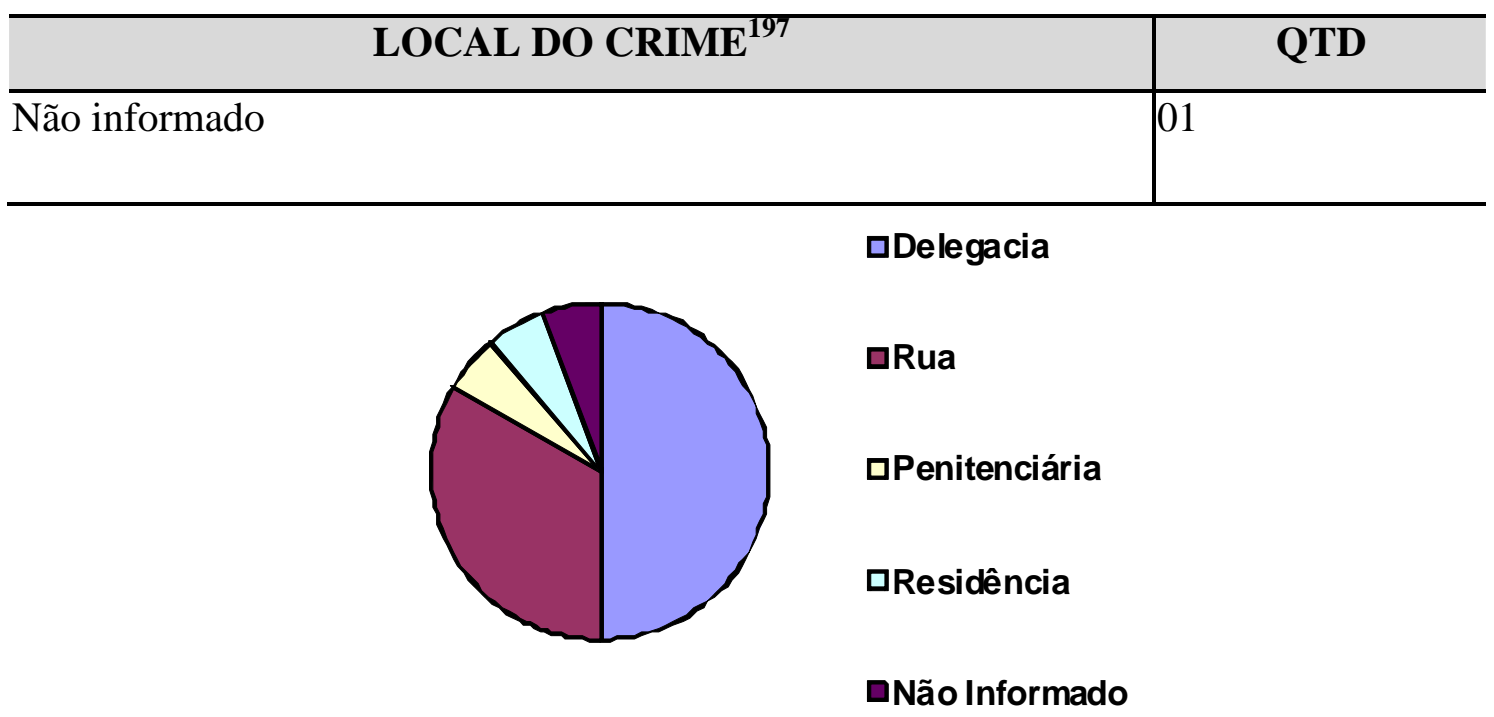




\section{Dimensiones histórico-sociológicas de la tortura en comisarías de Brasil: el caso Pernambuco}

Eso es un dato importante cuando se piensa en políticas públicas de prevención, pues la delimitación de un sitio específico facilita acciones de prevención y control.

Otro dato que llama la atención es el número de hombres y mujeres torturados. Frente a 17 hombres que fueron víctimas de tortura sólo hubo una mujer $^{198}$.

\begin{tabular}{l|l}
\hline \multicolumn{1}{c|}{ PERFIL DAS VÍTIMAS $^{199}$} & \multicolumn{1}{c}{ QTD } \\
\hline Homem & 15 \\
Mulher & 01 \\
Menor & 02 \\
\hline
\end{tabular}

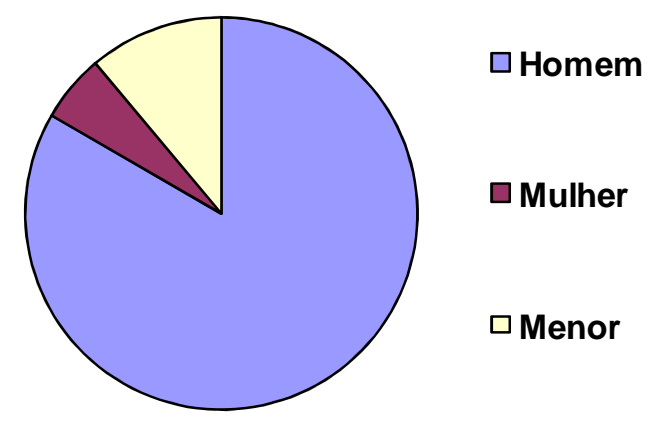

198 Com relação ao perfil das vítimas que denunciaram os crimes de tortura identifica-se a predominância do sexo masculino, em idade adulta e, conforme depoimentos relatados, entre as formas de tortura empregadas pelos policiais estão: a tortura psicológica, ameaça com arma de fogo, espancamento, aprisionamento em mala dos carros, chibatadas nos pés, cárcere privado, choques elétricos, saco na cabeça, pau-de-arara, entre outros. (PASSOS, 2010: 31).

199 Fonte: Departamento de Correição e Estatística da Corregedoria Geral/SDS. 
Dimensiones histórico-sociológicas de la tortura en comisarías de Brasil: el caso Pernambuco

\begin{tabular}{l|l}
\hline \multicolumn{1}{c|}{ MOTIVO $^{200}$} & \multicolumn{1}{c}{ QTD } \\
\hline Confissão & 07 \\
Não Relatado & 09 \\
Extorsão & 02 \\
& \\
\hline
\end{tabular}

๑ Confissão

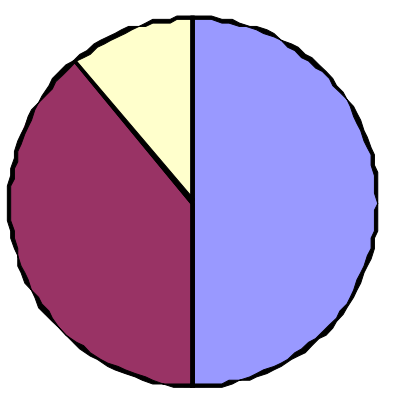

ם Não Relatado

口Extorsão

\begin{tabular}{l|l} 
TIPO $^{201}$ & QTD
\end{tabular}

200 Fonte: Departamento de Correição e Estatística da Corregedoria Geral/SDS.

201 Fonte: Departamento de Correição e Estatística da Corregedoria Geral/SDS. 
Dimensiones histórico-sociológicas de la tortura en comisarías de Brasil: el caso Pernambuco

\begin{tabular}{l|c}
\hline \multicolumn{1}{c|}{ TIPO $^{201}$} & QTD \\
\hline Espancamento & 14 \\
Aprisionamento em mala do carro & 03 \\
Seqüestro & 03 \\
Sufocamento & 02 \\
Choque elétrico & 02 \\
Ameaça com arma & 01 \\
Chibatada nos pés & 01 \\
Extorsão & 01 \\
Não informado & 02 \\
Outros & 01 \\
\hline
\end{tabular}

¿Espancamento

口Mala

口Sequestro

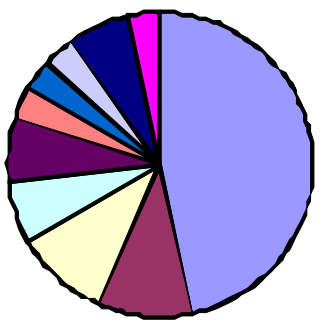

口Sufocamento

- Choque

口Arma

口Chibatada

पExtorsão

- Não Informado

口Outros 


\section{Dimensiones histórico-sociológicas de la tortura en comisarías de Brasil: el caso Pernambuco}

Passos señala que el discurso de intolerancia con la tortura no es suficiente si no hay acción en el sentido de cambiar la cultura de la corporación y sus prácticas internas. $^{202}$.

Aunque se halla muy extendida la creencia de que torturar comporta ventajas para el torturador, también se sabe que puede comportar riesgos. Así, la ecuación entre ganancias y pérdidas puede ser decisiva a la hora de optar por la práctica de la tortura, pero de las respuestas que obtuvimos se desprende que no parece haber mucho riesgo para quien la practica. Los entrevistados no parecían creer en la eficiencia del control interno de Asuntos Internos (Corregedoria), aunque los agentes la temen más que los comisarios.

¿Los Asuntos Internos consiguen punir eficientemente a quien practica la tortura? ¿Por qué crees eso?”

Yo creo que el crimen de tortura es muy difícil conseguir caracterizarlo. Asuntos Internos, como es la realidad de la policía, tiene una demanda mayor que el efectivo para investigar. Y tropezamos, yo ya investigué casos de ese tipo y tropezamos en algunas dificultades. Que es en la materialidad, no siempre el informe indica las lesiones, ni siempre hay, nos quedamos con la versión del policía contraria a la versión de la víctima de la tortura, y claro que divergen y no tenemos una tercera persona para corroborar o no el informe, o entonces que indique la materialidad, que ayude a saber quién dice la verdad. Es un crimen muy difícil... Entonces, yo no sé si podrían ser más eficientes o no. (CA6). ${ }^{\text {ccclxi }}$

No pueden castigar de forma eficiente porque no tienen estructura suficiente. Y mira que en nuestro Estado hasta que está bien. Yo conozco otros estados donde la situación es bastante peor. Y no es sólo la cuestión de castigar. Igual de importante, es la cuestión de inspeccionar y orientar. El castigo sería la última fase y Asuntos Internos no consigue hacer bien ninguna de ellas. (C3). ${ }^{\text {ccclxii }}$

$202 \quad$ (PASSOS, 2010: 39). 


\section{Dimensiones histórico-sociológicas de la tortura en comisarías de Brasil: el caso Pernambuco}

No. Por los ridículos índices de resolución de los casos, o incluso inexistentes. $(\mathrm{C} 2) .{ }^{\text {ccclxiii }}$

No. De entrada, hay una dificultad muy grande para denunciar la práctica de tortura (el miedo prevalece). En segundo lugar está la cuestión de la prueba, cuando el tipo de tortura empleada no deja vestigio. Finalmente, existe un serio problema que es el hecho de que los de Asuntos Internos son comisarios de policía que, nombrados momentáneamente para aquella función, juzgan a los compañeros, los cuales podrán estar en otra ocasión, nombrada para esa misma función. (C4). ${ }^{\text {cclxiv }}$

Yo creo que hay pocos casos así. Yo creo que se castiga, pero el problema es que tal vez el número de castigos sea muy inferior a la práctica de la tortura que existe. Es difícil de probar, porque muchas veces no deja vestigios, es la palabra de la víctima contra la palabra del policía. $(\mathrm{C} 1){ }^{\text {ccclxv }}$

Depende de si el torturador tiene o no una buena protección política interna. Si no tiene, es castigado severamente para servir de ejemplo. Pero la práctica de las investigaciones de Asuntos Internos s es más severa con crímenes de corrupción que de tortura. Aún hay una cierta tolerancia en muchos casos. No hay una clara interpretación del propio Asuntos Internos de lo que es o no es tortura. Las orientaciones internas son deficientes y no hay una formación que prevenga y combata la práctica de torturas. (CA5). ${ }^{{ }^{c c c l x v i}}$

No se consigue. Es difícil de probar. El llamado "saco" no deja marcas. Es la palabra del delincuente contra la del policía. Generalmente no se tienen testigos. Se abre una IP (investigación policial) y nada. Sólo si hay muerte y la cosa es descarada, lo que es difícil que ocurra. (C12). ${ }^{\text {ccclxvii }}$

No, pues muchas no dejan pruebas y otras veces la persona tiene miedo de denunciar. (C13). ${ }^{\text {ccclxviii }}$ 


\section{Dimensiones histórico-sociológicas de la tortura en comisarías de Brasil: el caso Pernambuco}

Los últimos años, no sólo Asuntos Internos de la Policía Civil, sino también de la SDS (Secretaria de Defensa Social) ha sido implacable. Llega a ser hasta un tribunal de excepción... Fue tortura, abren un PAD (Proceso Administrativo Disciplinar) y van a ser muy rigurosos... incluso porque hay una ONG y toda una exigencia sobre ellos. (A1). ${ }^{\text {ccclxix }}$

Sí. Asuntos Internos hoy viene haciendo un trabajo que yo no veía hace siete años... Hoy, tú haces guardias y llega una denuncia, quieres librarte de aquel tío. Porque el comisario no quiere que lleguen allí y pregunten: ¿qué está haciendo ese preso aquí? ¿Por qué no fue a la cárcel?... Entonces, si Asuntos Internos impone ese miedo es porque está dando resultado es porque está castigando a alguien. Pero si falta Asuntos Internos, si no hay efectivo para todo el Estado, ¿cómo un efectivo reducido va a hacer efecto? (A2). ${ }^{\text {ccclxx }}$

Cuando se dan cuenta es porque ya se han hecho más de mil. (A4). ${ }^{\text {cclxxi }}$

Castiga eficientemente pero algunas veces exagera. Extrapola un poquito, porque algunas veces dificulta la defensa del policía. Creo yo. Coloca cáscaras de plátano para dificultar la defensa del policía. (A3). ${ }^{\text {ccclxxii }}$

¿Crees que Asuntos Internos influye en la disminución de la práctica de la tortura?

No. Creo que quién no practica es gracias a sus propios valores o por miedo a que salga a la luz y que el Ministerio Público (equivalente al Tribunal Supremo) haga una denuncia. Nosotros hasta nos olvidamos de que Asuntos Internos existe. (C3). ${ }^{\text {ccllxxiii }}$

Inocua. (C2). ${ }^{\text {ccclxxiv }}$

Deficiente. Asuntos Internos actúa muchas veces presionado por entidades externas. No demuestra claramente que tiene una política interna y moderna volcada en la destrucción 


\section{Dimensiones histórico-sociológicas de la tortura en comisarías de Brasil: el caso Pernambuco}

específica de la tortura. Todas las infracciones tienen el mismo peso. El castigo es el que va a variar según las circunstancias de lo cometido o del "estatus" del policía. (CA5). ${ }^{\text {cclxxv }}$

Poca, no conozco ningún caso de agente de policía que haya sido despedido por practicar tortura. $(\mathrm{C} 13){ }^{\text {ccclxxvi }}$

La inspección influencia. Sin embargo, en los Asuntos Internos donde yo trabajo están los mayores torturadores de la PC (Policía Civil), que hoy prefieren combatirla. (C12). ${ }^{\text {ccclxxvii }}$

Aunque $\mathrm{C} 4$ y $\mathrm{C} 1$ hayan dicho que $\mathrm{AI}$ ejerce influencia para impedir nuevos casos de tortura, creemos que se refieren a la hipotética situación de que AI funcione con efectividad, o bien se resisten a admitir su inefectividad. Los mismos afirmaron en la pregunta anterior que AI no era eficaz y, más adelante, reconocen que no saben decir de un solo caso de un policía punido por $\mathrm{AI}^{203}$.

Yo creo que sí. Ahora depende de cada caso. Dejan de practicar, disminuyen o tienen más cuidado. A partir del momento en que Asuntos Internos actúa más, muestra más casos castigados, cuando los crímenes de tortura son revelados, porque Asuntos Internos actúa y el tío es despedido, es castigado. Entonces eso la inhibe. $(\mathrm{C} 1) .{ }^{\text {ccclxxviii }}$

Quién practica la tortura pasa a tener más cuidado para no dejar rastro. (C4). ${ }^{\text {ccclxxix }}$

\section{¿AI es considerada corporativista?}

203 "Trata-se, basicamente de crime que geralmente escapa à punição, seja pelos órgãos disciplinares internos, seja, o que é mais importante, pela justiça criminal nos termos da lei pertinente". (AMNISTÍA INTERNATIONAL, 2001: 06). 


\section{Dimensiones histórico-sociológicas de la tortura en comisarías de Brasil: el caso Pernambuco}

Sí. Algunas veces eso es importante para que no haya injusticias, algo muy común cuando eres evaluado por alguien que no tiene ni idea de lo que es tu trabajo, ni en qué condiciones trabajas. Pero también está el lado de que no quieras quemarte con tus compañeros. (C3). ${ }^{\text {ccclxxx }}$

Eso tal vez exista para/en algunas personas. Yo no lo veo como una imagen de Asuntos Internos. No lo veo así no. Creo que la mayor dificultad es operacional y la propia dificultad del crimen. Es la cuestión de materializar. Muchas veces la persona, la víctima de la tortura en aquel primer momento en que se revela contra la práctica y va a tomar alguna medida, ella comunica, notifica a los órganos que serían los de atribución para conocer e investigar eso, pero como no hay condiciones de dar una respuesta rápida, entonces la propia tardanza, cuando vamos atrás de aquella información, para conducir mejor la investigación las personas ya ha pasado aquel primer momento, a veces ya no colaboran de la misma forma a como estaban dispuestas en aquel primer momento y eso confunde. (CA6). ${ }^{\text {ccllxxxi }}$

Uno de los aspectos más impresionantes para nosotros fue cuando preguntamos si conocían algún caso de policía punido por tortura. Todos los entrevistados han admitido que sigue existiendo tortura y todos conocen algún torturador aunque ningún entrevistado conocía un solo caso de castigo por la práctica de tortura ${ }^{204}$.

¿Conoces a algún policía punido por la práctica de la tortura?

Mientras yo respondía la cuestión anterior estaba pensando, sólo de tortura, yo no me acuerdo, pero hubo, pero yo no me acuerdo. $(\mathrm{C} 1){ }^{\text {ccclxxxii }}$

204 "Impunidade generalizada para os perpetradores da tortura, agravada por omissao sistemática na aplicação da Lei da Tortura. Fracasso institucional da justiça criminal, em nível estadual, para assegurar a implementação da Lei da Tortura". (AMNISTIA INTERNACIONAL, 2001: 11). 


\section{Dimensiones histórico-sociológicas de la tortura en comisarías de Brasil: el caso Pernambuco}

Personalmente, por tortura no. (CA5). ${ }^{\text {ccllxxxiii }}$

No. (C2). ${ }^{\text {ccclxxxiv }}$

No. Ningún. (C3). ${ }^{\text {ccclxxxv }}$

No. Al menos no recuerdo. (C4). ${ }^{\text {ccllxxxvi }}$

Tortura específicamente... Yo tampoco sigo los resultados... Pero escucho más hablar de suspensión y despido como consecuencia de la corrupción... De tortura específicamente yo no me acuerdo no. (CA6). ${ }^{\text {ccclxxxvii }}$

No. $(\mathrm{C} 13){ }^{{ }^{\text {ccclxxxviii }}}$

No. (C12). ${ }^{\text {ccclxxxix }}$

Conozco a personas de mi promoción y de los veteranos que perdieron el cargo por tortura que resultó en muerte. Y es interesante que de esos tres policías, uno llevaba más de 30 años de policía, otro más de 10 años de policía y otro que es de mi promoción, 3 años de policía. (A1). ${ }^{\operatorname{cccxc}}$

Conozco militares. Policías civiles, no. (A2). ${ }^{\text {ccxci }}$

Conozco a unos 4. Fueron dos torturas que fueron famosas aquí en Pernambuco y que el tipo no aguantó y murió. (A4). En el medio policial, él es discriminado. ${ }^{\text {cccxcii }}$

Por tortura, no. (A3). ${ }^{\text {cccxciii }}$

¿Crees que hay impunidad? 


\section{Dimensiones histórico-sociológicas de la tortura en comisarías de Brasil: el caso Pernambuco}

Si la investigación de la tortura fuera más frecuente, si fuese una prioridad y los resultados de aquellas investigaciones fueran ampliamente divulgados yo creo que eso serviría también para inhibir un poco la práctica. Porque desgraciadamente algunos casos de irregularidades practicadas por policías no son investigados. Los jefes, digámoslo así, ellos se enteran de que un determinado comisario, agente o escribiente tiene una conducta irregular, pero ahí no se busca materializar aquella conducta para que sea castigado. ¿Qué es lo que se hace? Se le transfiere de una unidad a otra, como si aquello hiciese que, tal vez, que él no use más aquella práctica. O se le suspende temporalmente de la actividad, se queda en stand by, sin función específica, sin unidad para trabajar. (CA6). ${ }^{\text {cccxciv }}$

Para mí, es lo mismo que ocurre con otros crímenes. Si no hubiera tanta impunidad no habría tanta tortura. Necesitamos de campañas de concienciación que hagan que el comisario perciba que no es normal practicar. Y necesitamos también castigos para los que insistan en practicar. (C3). ${ }^{\text {cccxcv }}$

Es difícil combatirlo. Si yo identifiqué que disminuyó no fue por una acción institucional, no es una campaña lo que hace que se acabe. $(\mathrm{C} 1){ }^{\text {cccxcvi }}$

CA6 alegó que había dificultades para investigar los delitos de tortura por la dificultad de obtener testigos, pero olvidó que eso también pasa con otros delitos y eso no es excusa para no investigarlos.

Hay muchos casos en los que dependemos de declaraciones de testigos que no siempre conseguimos con facilidad, en los que no tenemos cómo garantizar su seguridad, que lo que fue relatado sea reservado y, consecuentemente, la seguridad para aquella persona. Pero aún es muy importante la información de quien oyó hablar y de quien presenció el hecho. (CA6). ${ }^{\text {ccxcvii }}$

¿Es común que los testigos cambien sus versiones? 


\section{Dimensiones histórico-sociológicas de la tortura en comisarías de Brasil: el caso Pernambuco}

No sé si ocurre mucho, pero pasa. Cuando hay un cambio, a veces da la impresión de que fueron amenazadas, pero ellas no dicen que los fueron. (CA6). ${ }^{{ }^{c c c x c v i i i}}$

Y C3 también insistió en la falta de seguridad para los testigos y de cómo la policía no puede contar mucho con ellos:

\footnotetext{
Es común que ellos no digan nada de lo que vieron para no sufrir amenazas o incluso que los maten. Ya vi casos en los que los testigos de homicidios (cuando son grupos de exterminio) fueron asesinados tras sus testimonios. Y, finalmente, es muy muy común un testigo que cuando llega al juicio, y tras ser amenazado por los criminales, cambia todo el testimonio dado en la comisaría. ¡Es muy difícil trabajar así! (...)En algunos casos es como si la única forma de llegar a la verdad fuera a través de un testigo, pero, a la vez, presionarlo para testificar es cómo condenarlo a la muerte. (C3). ${ }^{\text {ccxxcix }}$
}

Surgió también el argumento de que cuando hay denuncias de tortura u otra práctica delictiva, los policías son penalizados sólo con una traslado (procedimiento informal) y que eso es muy común.

“¿Por qué ese procedimiento irregular?” (de trasladar para otra sección cuando se debería castigar)

A veces es porque ellos no tienen realmente ningún indicio, ningún indicador para iniciar aquella investigación... Lo que yo creo es que desafortunadamente aún existe el corporativismo y para algunas personas no es interesante que eso sea investigado... Porque los jefes también habrían utilizado aquella práctica en algún momento, porque tal vez aquel policía ya hizo algún favor para el jefe y ahí el jefe va devolverle aquel favor (...). 


\section{Dimensiones histórico-sociológicas de la tortura en comisarías de Brasil: el caso Pernambuco}

Y a veces es falta de valor, realmente. Yo creo que, en algunos casos, no sólo en la investigación de la tortura porque hay determinados policías que si hay conocimiento de que realmente son muy contundentes en las prácticas irregulares, yo creo que existe miedo, ellos son temidos. $(\mathrm{CA} 6){ }^{\mathrm{cd}}$

¿Temidos por sus relaciones con los políticos?

De su valor en determinadas conductas. En prácticas criminales, no específicamente violentas, de tortura. $(\mathrm{CA} 6){ }^{\text {cdi }}$

Si no es fácil denunciar, tampoco lo es elucidar un delito de ese tipo, algo que comprenderemos escuchando sus discursos sobre las consecuencias de quien lo intenta. Todos los entrevistados reconocieron que hay presión sobre quien intenta investigar a un compañero de trabajo.

“Ha tratado algún caso de un policía acusado de tortura y sufrió alguna presión para no profundizar en la investigación?”

Con relación al Ministerio Público (equivalente al Tribunal Supremo) y al Juez no. Con relación a los compañeros, sí, sufrí presión. Es muy difícil investigar tortura. (CA6). ${ }^{\text {cdii }}$

“Conoces a algún policía que sufriera presión por investigar a un compañero?”

Conozco. El policía, cuando es acusado de tortura, principalmente si está siendo acusado por alguien del mundo del crimen, primero cree que ni debería estar siendo investigado, porque es una cosa más pequeña. (...). (C1). ${ }^{\text {cdiii }}$ 


\section{Dimensiones histórico-sociológicas de la tortura en comisarías de Brasil: el caso Pernambuco}

Conozco algunos. $(\mathrm{C} 4){ }^{\text {cdiv }}$

Sí. (C2). ${ }^{\text {cdv }}$

Sí. Conozco una comisaria que sufrió mucha presión porque estaba investigando un caso de tortura. Los compañeros la llamaban, censuraban su conducta, pues alegaban que el investigado no era ningún delincuente. $(\mathrm{C} 3){ }^{\text {cdvi }}$

Sí. Conmigo mismo ya ocurrió. Acabé siendo retirado de la investigación con el argumento de que debería asumir otra comisaría y que esta era muy agitada, lo que me impediría continuar con la investigación. $(\mathrm{C} 13){ }^{\text {cdvii }}$

No. $(\mathrm{C} 12){ }^{\text {cdviii }}$

Yo no diría presión, pero hay un rechazo. No está bien visto, no es aceptado. No lo llaman para tomar una caña. (A1). ${ }^{\text {cdix }}$

Esa visión es trivial. El policía que trabaja en Asuntos Internos no está bien considerado. Está mal visto. Si él está allí es siempre para perjudicarte... En la cabeza de los policías él está allí porque quiere destacarse gracias a tu error. Él quiere obtener la respuesta perjudicándote para mostrarle él el resultado a su jefe... (A2). ${ }^{\text {cdx }}$

En el medio policial está discriminado. De cualquier forma, se está inspeccionando su trabajo y a nadie le gusta ser inspeccionado. (A3). ${ }^{\text {cdxi }}$ 


\section{Dimensiones histórico-sociológicas de la tortura en comisarías de Brasil: el caso Pernambuco}

\subsubsection{Presión externa}

\subsection{Influencia de la Constitución Federal de 1988}

Cuando entró en vigor la nueva Constitución Federal ella prohibió, rotundamente, la tortura ${ }^{205}$. Eso era la demostración del fin de la dictadura que había torturado a académicos, periodistas y artistas. Pero eso no produciría muchos cambios, pues antes de la CF ya estaba prohibido torturar. El principal cambio introducido por la $\mathrm{CF}$ fue establecer reglas objetivos para las oposiciones, dar fuerza a la Fiscalía y establecer el compromiso de fiscalizar la policía y, sobre todo, garantizar los derechos a los ciudadanos.

¿Hoy se practica la tortura más o menos que antes? ¿La Constitución Federal tuvo alguna influencia en ello? ¿Por qué crees eso?”

Con relación a la CF (Constitución Federal) específicamente yo no creo que se haya alterado, tal vez yo creo que hoy, de unos dos años para acá, por el propio cambio, en algunas situaciones dentro de la policía, yo creo que eso disminuyó un poco, hasta los instrumentos de investigación que facilitan la prueba del crimen, realmente eso yo creo que disminuyó. No hay por qué hacerlo más. (CA6). ${ }^{\text {cdxii }}$

Existe menos, de cara a la venida de nuevos cuadros y una pequeña mejora en la investigación. (C2). ${ }^{\text {cdxiii }}$

205 "A longa tradição (e experiência) de uma polícia de gente, dócil em relação aos privilégios de classe e status em sua atividade rotineira de imposição da ordem, e de uma polícia de moleque, nunca hesitante em usar o chicote no trabalho de domesticação das rebeldias individuais e coletivas das classes baixas traduziu o problema do controle social coercitivo nos termos de alguma redução do poder de polícia no Brasil, como condição de construção da democracia no plano das interações sociais rotineiras e cotidianas". (PAIXÃO, 1998: 01). 


\section{Dimensiones histórico-sociológicas de la tortura en comisarías de Brasil: el caso Pernambuco}

¡No tengo dudas en cuanto a eso! Menos por la condena de la Constitución a la tortura, sino que es más por los poderes que se le dieron al Ministerio Público (equivalente al Tribunal Supremo) y, principalmente, por el ingreso de nuevas generaciones a la policía (gracias a la imposición de las oposiciones públicas). Los nuevos comisarios no tienen el perfil de antes y son cada vez menos tolerantes con la tortura. (C3). ${ }^{\text {cdxiv }}$

Se practica menos que antes. No creo en la influencia de la Constitución o de la ley ordinaria porque quién practica la tortura lo hace con conocimiento de su ilegalidad. Lo que cambió fue la nueva generación de policías, que ingresaron en la institución por medio de oposiciones, que no aceptan esa práctica antigua. (C4). ${ }^{{ }^{d d x v}}$

Evidentemente que sí (hubo reducción). Porque existen nuevos actores también responsables por las garantías constitucionales individuales. La sociedad como un todo es más ciudadana y cuestiona más las arbitrariedades cometidas por la policía, además claro del papel del Ministerio Público (equivalente al Tribunal Supremo) al ejercer el control externo de las actividades policiales. La Academia está un poco más sensibilizada por el tema, pero a pesar de todo, no tiene una política clara de formación hacia los derechos humanos. (CA5). ${ }^{\text {cdxvi }}$

Menos. Sí, creo que la Constitución al vetar algunas prácticas como la prisión para averiguaciones y al instituir algunos mecanismos de control, y también la libertad de prensa contribuyó. Se hizo famoso en Recife el caso en que fue encontrada en una comisaría una palmeta (instrumento de tortura). (C13). ${ }^{\text {cdxvii }}$

Menos, seguro. La inspección es más intensa. Sí, el art. $5^{\circ}$ que trata de los derechos fundamentales actúa directamente en relación a las leyes que castigan la tortura y la práctica investigativa ilegal. (C12). ${ }^{\text {cdxviii }}$ 


\section{Dimensiones histórico-sociológicas de la tortura en comisarías de Brasil: el caso Pernambuco}

\subsection{Fiscalía}

Algunos creen que la fiscalía ejerce alguna presión para que los policías trabajen en conformidad con la ley, otros llegan a decir que la fiscalía a veces es connivente con la tortura ${ }^{206}$.

“Y la fiscalía influyó de alguna manera en esa disminución de la tortura?”

Claramente. El Ministerio Público (equivalente al Tribunal Supremo) es de fundamental importancia en la disminución de la tortura en las comisarías policiales por las denuncias que hace (CA5). ${ }^{\text {cdxix }}$

(...) el Ministerio Público (equivalente a la Fiscalía) pasó a ejercer lo que ellos llaman control externo de la actividad policial. Que implica visitas de los inspectores a las comisarías, a veces dos o tres inspectores en el mismo momento, en las que visitan las instalaciones físicas, piden ver y, se les facilitan todos los libros de registro, piden la relación de investigaciones instauradas y remitidas a la Justicia, piden el cuantitativo del efectivo, para tener una idea de la estructura física de la comisaría, coincidentemente eso comenzó a ocurrir también tras ese cambio de, a mi entender, un cambio de prácticas en la investigación y prácticas en la administración.... Eso viene ocurriendo hace algo más de un año... No oí comentarios, pero como ellos van frecuentemente y, no siempre avisan, claro que yo creo que quién tiene determinadas prácticas irregulares va a tener más cuidado con esas prácticas. (CA6). ${ }^{\text {cdxx }}$

206 "A Anistia Internacional observou também com preocupação que os numerosos relatos minuciosos e documentados de incidentes de tortura reunidos pelos promotores não foram encaminhados para abertura de processo nos termos da Lei da Tortura pela vara criminal da Promotoria". (ANISTIA INTERNACIONAL, 2001: 56). 


\section{Dimensiones histórico-sociológicas de la tortura en comisarías de Brasil: el caso Pernambuco}

Yo creo que sí. Tras la Constitución del 88, el Ministerio Público (equivalente al Tribunal Supremo) pasó a tener un papel mucho más activo. Yo tengo cuidado en mi trabajo para no caer en sus manos y veo a los compañeros con el mismo cuidado. Por eso creo que tuvo un papel importante en la reducción de la tortura. Aunque ese no fuera su objetivo. Por la presión que ellos ejercen sobre la policía. $(\mathrm{C} 3){ }^{\mathrm{cdxxi}}$

Sí. Cuando demuestra proactividad, adelantando la producción de pruebas y solicitando investigación a órganos superiores, incluso del primer escalafón del Gobierno. $(\mathrm{C} 2){ }^{\text {cdxxii }}$

Sí, pero no tanto debido a su estructura deficiente. $(\mathrm{C} 13){ }^{\text {cdxxiii }}$

Yo creo que es muy insignificante, es insignificante. Una de las cosas con las que se deberían preocupar en relación a la tortura, es con modelos de procedimientos para el testimonio de víctimas, acusados y testigos, con que existan preguntas obligatorias sobre cómo fueron tratadas por la policía. Que tuvieran esa oportunidad. $(\mathrm{C} 1).){ }^{\text {cdxxiv }}$

No. El Ministerio Público (Fiscalía) está distante de la policía. (C4). ${ }^{\text {cdxxv }}$

No creo. Por lo menos muchos fiscales aquí en el Estado no están preocupados en como solucionan el crimen. Ellos quieren la solución. $(\mathrm{C} 12) .{ }^{\text {cdxxvi }}$

Los comisarios tienen claro que cuando la fiscalía ejerce su papel correctamente tiene una gran influencia sobre la policía. Incluso cuando ellos intentan disminuir la importancia de ese tipo de actuación dejan entrever que la actuación de la fiscalía es uno de los puntos fundamentales de presión sobre los comisarios.

¿La fiscalía consigue ser eficiente en los asuntos de tortura? 


\section{Dimensiones histórico-sociológicas de la tortura en comisarías de Brasil: el caso Pernambuco}

Ellos son diligentes, quieren estar presentes en todos los actos, por lo menos es mi experiencia aquí, y exigen conclusión y agilidad en el procedimiento. (CA6). ${ }^{\text {cdxxvii }}$

En la capital mucho más, pues las relaciones son muy impersonales Pero en la zona rural yo creo que es la excepción, el comisario y el fiscal, en general, tienen una buena relación y eso estorba para una mayor inspección del Ministerio Público (equivalente al Tribunal Supremo). $(\mathrm{C} 3){ }^{\mathrm{cdxxviii}}$

\subsection{ONGs}

Las ONGs consiguen ser eficientes, pero no se preocupan con la actividad policial de forma general y solamente se esfuerzan en la protección de personas que ellos están acompañando en un determinado caso. Por eso que los policías no consiguen verlas como una amenaza para el uso de la tortura.

Hay un caso emblemático en Brasil que es la existencia de algunas ONGs que se llaman "Tortura Nunca Mais" y tiene sede en algunas capitales. Tales ONGs tuvieron una acción destacada en la búsqueda de los desaparecidos, el acceso a los archivos públicos, reparaciones a las víctimas, etc. Pero parece que se ocupan únicamente de la tortura en el período de la Dictadura, como si sólo fuera importante la tortura política. En verdad no es la tortura política, son los torturados lo que importa. En la dictadura se torturó aquellos a los que normalmente no se tortura. Por eso la CF le dio énfasis fueron creadas ONGs contra la tortura.

No hay ninguna referencia de los policías a su actuación. Uno de ellos llegó a subrayar sus constantes cooperaciones en proyectos financiados por el Gobierno y al hecho de que la única presidenta de tal ONG, fundada en Recife, era empleada de confianza del Gobierno en la área de seguridad, sugiriendo una ausencia de imparcialidad. 


\section{Dimensiones histórico-sociológicas de la tortura en comisarías de Brasil: el caso Pernambuco}

Buscamos los sitios de internet de esa ONG en algunas capitales. No encontramos el sitio de la ONG de Recife, pero encontramos el sitio de Rio de Janeiro $^{207}$ y Sao Paulo ${ }^{208}$. En los dos el énfasis es casi absoluto sobre la tortura ocurrida en la dictadura. Son grupos que buscan encontrar los cuerpos de sus parientes, reparación para las familias y punición para los torturadores. Todo en el contexto de la dictadura de 1964-1984.

¿Y las ONGs actúan para disminuir la práctica de la tortura?

No, quedaron estigmatizadas cómo siendo defensoras de delincuentes, de modo que la propia sociedad no da crédito a la instituciones que defienden los derechos humanos, salvo en casos excepcionales, cuando hay errores y el torturado era inocente. (C13). ${ }^{\text {cdxxix }}$

Sobre esas, nadie ve que se hable de ellas. Son tragaperras. (C12) ${ }^{\text {cdxxx }}$

No están bien consideradas por la policía. Hacen un trabajo como el de la prensa... Están allí para exigirte, para ver algo mal y mostrarlo, "Oye, estamos aquí vigilándote". Es como si fuera un Asuntos Internos informal. Porque si una ONG de esas te pilla haciendo algo mal... (A2). ${ }^{\text {cdxxxi }}$

207 "O Grupo Tortura Nunca Mais/RJ (GTNM/RJ) foi fundado em 1985 por iniciativa de expresos políticos que viveram situações de tortura durante o regime militar e por familiares de mortos e desaparecidos políticos e tornou-se, através das lutas em defesa dos direitos humanos de que tem participado e desenvolvido, uma referência importante no cenário nacional. Considerando que o regime ditatorial contribuiu decisivamente para o esgarçamento e a deterioração de valores éticos, o GTNM/RJ constituiu-se em torno do resgate de valores, da dignidade, da defesa e dos direitos da cidadania. Desta maneira, tem assumido um claro compromisso na luta pelos direitos humanos, pelo esclarecimento das circunstâncias de morte e desaparecimento de militantes políticos, pelo resgate da memória histórica, pelo afastamento imediato de cargos públicos das pessoas envolvidas com a tortura, pela formação de uma consciência ética, convicto de que estas são condiçães indispensáveis na luta hoje contra a impunidade e pela justiça". (h t t $p: / / w w w$. to $r$ t u $r$ a n u $n$ c a m a is $-r j$ .org.br/Conteudos.asp? REfresh=2011121321515989882638\&Pagi n a $=Q$ u em Somos \& Titulo $=$ Quem\%20Somos). Acceso en 10/05/2011. 


\section{Dimensiones histórico-sociológicas de la tortura en comisarías de Brasil: el caso Pernambuco}

\subsection{Intolerancia de la sociedad con la tortura}

En Brasil sólo hay intolerancia con la tortura para los miembros de las clases media y alta. La tortura de los pobres sólo es intolerable cuando se difunde en periódicos y en la TV y entonces la gente se siente obligada a indignarse. Si funciona de manera discreta nadie pide explicaciones sobre el trabajo de la policía, aunque la mayoría sepa como "trabaja". Y es más, los más susceptibles de ser torturados son los que más aprueban tal práctica, al menos explícitamente (Almeida, 2007).

La paradoja es que están codo con codo aquellos que quieren una policía que mata y tortura y aquellos que desean una policía que respeta los derechos humanos y un sistema de prisión que sea capaz de resocializar los encarcelados (FERREIRA, 2002: 154) y no es raro verlos cambiar de posición cuando les toca ser las víctimas de delincuentes o policías.

Adorno $(1994)^{209}$, Pinheiro \& Sader $(1985)^{210}$ y Zaluar $\left(1985^{211}\right)^{212}$ ya han llamado la atención sobre la diferencia en la aplicación de las leyes de acuerdo con la

209 Para Adorno, el funcionamiento normativo del aparato penal tiene, por efecto, la objetivación de las diferencias y de las desigualdades, la manutención de las asimetrías, la preservación de las distancias e yerarquias. (1994: 149).

210 "A atuação policial no Brasil sempre se exerceu prioritariamente contra as classes populares, contra a maioria dos cidadãos. Nunca prevaleceu nesse país a noção de que a função de polícia é uma delegação feita pelos cidadãos ao Estado para que a proteção, a segurança de todos seja melhor concretizada, sem que os cidadãos recorram à violência individual”. (PINHEIRO \& SADER, 1985: 79).

211 Según Zaluar no hay, en Brasil, la punición no es incondicional para todos los ciudadanos como está escrito en la ley, mas una condenación variable, de acuerdo con una 'moral de classe' de quien fue victima: "pobre ou um 'grande', um trabalhador ou uma empresa”. (1985: 148).

212 "Nao ter dinheiro para consumir os bens cada vez mais oferecidos no mercado equivale, para os pobres, especialmente se pertencentes a grupos raciais (como os negros) e residenciais (como os favelados), mas principalmente os despojados "menores de rua", a ser objeto da suspeita de cometer atos ilegais ou ilícitos ou, pior, de ser agente da violência. Fazer parte das chamadas classes 


\section{Dimensiones histórico-sociológicas de la tortura en comisarías de Brasil: el caso Pernambuco}

situación económica de los involucrados. Ferreira ${ }^{213}$ señalaba la gran aceptación de la tortura en la sociedad contemporánea de Brasil. Aún más, según Ferreira, Caldeira argumenta que esta defensa de infligir dolor al cuerpo funciona como un medio de garantizar un orden jerárquico. En este orden, la mayoría de la población no tiene sus derechos respetados y el castigo severo a los criminales debe marcar su condición inferior en esta jerarquía. (Ferreira, 2002:142).

La arraigada creencia de que la sociedad apoya el uso de la tortura queda clara en los siguientes discursos de policías...

¿Cree que la sociedad apoya el uso de la tortura?”

Del mismo modo La institución la apoya desde que no le cause daño, desde que no exponga a la sociedad a una situación vergonzosa, una situación embarazosa. Pero en ese caso de tortura que cité que la gente quería linchar al tipo, pero si muere, ahí la gente es la primera en pedir que se castigue a los policías. Es una relación de infidelidad entre sociedad y policía. Es todo cuestión de intereses. (A1). ${ }^{\text {cdxxxii }}$

perigosas colocou os membros das classes populares ou do proletariado em situação paradoxal $e$ dilema de difícil saída, como já apontaram inúmeros estudos. A experiência da exclusão política e social e do arbítrio e violência institucionais foi pensada com base nos códigos morais da vida privada e não nos do direito, da justiça e da cidadania, cuja lógica ainda lhes permanece estranha $e$ distante. Daí a perseguição violenta e, em algumas tristes cidades, a prática do que é chamado "extermínio" de crianças e adolescentes pobres - os "menores" - levada a efeito por grupos também integrados de policiais ou ex-policiais, em geral os que participam do crime organizado, extorquindo ou vendendo armas aos jovens envolvidos no tráfico, assalto e roubo”. (ZALUAR, 1994: 181).

213 “(...) despertou-me especial interesse opiniões recorrentes dos entrevistados em relação a crimes e punições. Uns reivindicando leis que estabelecessem a pena de morte e prisão perpétua para 'bandidos'. Outros defendendo execuções sumárias de assaltantes e traficantes por grupos de extermínio e policiais. Alguns apoiando o linchamento, ainda sustentando, como forma de conteçao da criminalidade e punição dos infratores, a ocorrência de novos massacres como o do Carandiru, onde morreram 111 presos em 1992 na Casa de Detençao de São Paulo, e o da Candelária, onde foram assassinados 8 adolescentes, moradores de rua, nas proximidades da Igreja da Candelária no Rio de Janeiro, em 1993. Em todas as falas o 'bandido' parece perder seus direitos à integridade física, à vida (...)”. (FERREIRA, 2002: 8). 


\section{Dimensiones histórico-sociológicas de la tortura en comisarías de Brasil: el caso Pernambuco}

Yo creo que la sociedad también apoya el resultado y no está preocupada en saber cómo fue obtenido. (A2). ${ }^{\text {cdxxxiii }}$

Sí. (C13). ${ }^{\text {cdxxxiv }}$

Claro. En crímenes violentos la mayoría absoluta de la población apoya. (C12). ${ }^{\text {cdxxxv }}$

No. (A4). ${ }^{\text {cdxxxvi }}$

La apoyaba, la apoyaba. Porque decían, ladrón merece que le zurren. El tío que lucha para conseguir una moto, una bicicleta... el miserable sale de no sé dónde para llevársela. Un cabrón de esos merece que le zurren, tiene que llevarse palos... ¿Y los familiares no protestaban? la minoría, porque si protestasen se llevaban palos también. A veces llegaba uno para quejarse y le decíamos si te parece mal ocupa su lugar, entonces ya decían no. (A3). ${ }^{\text {cdxxxvii }}$ 


\section{Dimensiones histórico-sociológicas de la tortura en comisarías de Brasil: el caso Pernambuco}

\subsection{Conclusión}

Cuando surgen escándalos sobre policías que han torturado a sospechosos la reacción de la sociedad e incluso de la corporación policial es de parecer escandalizada, percibiéndolos como monstruos o sádicos ${ }^{214}$. Pero una mirada más profunda puede ser suficiente para comprender que hay varios factores actuando en el interior de la organización policial que posibilitan que alguien que jamás practicó actos de violencia pueda tornarse un torturador profesional. Cuando observamos los discursos de los policías vemos que en el primer paso por la Academia de Policía, ellos empiezan a aprender que la tortura es imprescindible para resolver diversos casos, principalmente los crímenes patrimoniales. Tal aprendizaje no ocurre en las clases, sino en el ambiente de la Academia y, por supuesto, algunos ya llegan a ella con la creencia que es necesario torturar. Aunque no la enseñe en la clase, la Academia no está interesada en disuadir de la oportunidad de la tortura a los recién ingresados en la carrera policial.

También aprenden los policías en formación que los derechos humanos no funcionan en el trabajo de "verdad", en la práctica. Es el principio de la asimilación de la "creencia" o "mito" de que la tortura es "necesaria" 15 . Perciben que al torturar

\footnotetext{
$214 \quad$ "Embora seja tentador encarar os que torturaram e assassinaram no Brasil como personalidades patologicamente extraordinárias, grande parte das pesquisas sociopsicológicas em outros contextos nos afastam dessa conclusão. Impressionante conjunto de estudos, recentes $e$ antigos, que salientam a natureza "comum" dos que cometem atos inimagináveis de maldade demonstram que, em muitos casos, esses perpetradores são induzidos a praticar atrocidades. Eles foram sujeitos a poderosas forças situacionais que afrouxam os modos habituais de funcionamento moral (Bandura, 1999)." (HUGGINS, 2006: 258).

215 A reprodução destes elementos culturais informais se daria na rotina policial em que os neófitos aprendem 'praticamente' com os veteranos, configurando uma formação policial informal raval da formação dos cursos oficiais das instituições policiais. (RATTON, 2007: 146)
} 


\section{Dimensiones histórico-sociológicas de la tortura en comisarías de Brasil: el caso Pernambuco}

a quien puede ser torturado ${ }^{216}$ es muy raro que alguien sea punido y que hay una gran tolerancia con la práctica entre los policías y en la sociedad. Más que eso, perciben que la mayoría de los policías más presentes en portadas de periódicos son policías que torturan. Pues hay una parcela de la sociedad civil que desea una policía más represiva y violenta para los criminales $^{217}$, a partir de una concepción de derechos que se aplica solamente a los que son considerados "ciudadanos de bien".

Después, cuando salen de la Academia, van descubrir que la realidad es muy distinta de lo que algunos profesores decían. Que las condiciones de trabajo eran más precarias de lo que podrían suponer. Se sentirán abandonados, sin un "manual" que les diga que hacer en las más diversas situaciones, pues la policía brasileña es demasiado informal y sólo hay procedimientos predeterminados para los actos administrativos. El nuevo policía va a aprender todas las otras cosas que ocurren en una comisaría con sus colegas o arreglarlas a su manera. Por eso el conocimiento pasado de un policía para otro es fundamental. Tendrán nuevos "profesores": sus colegas más antiguos, que van a enseñarles cómo obtener resultados con pocos medios. Los estudios revelan, véase en el próximo capítulo, que los resultados de la violencia eran más efectivos cuando los "profesores" aprendían con otros "profesores". Es decir, la influencia de los colegas más antiguos para transmitir los

\footnotetext{
216 "Em relação à existência de grupos sociais que podem ser considerados merecedores da agressão física ou mesmo de privação da vida, há o estudo de Cardia (1994) sobre 'exclusão moral'. Segunda ela, esta exclusão dita que quem está fora da comunidade moral, ou se opõe a ela, não evoca injustiça. Assim, quaisquer danos ou maus tratos são justificados ou vitimização e exposição à violência num período recente (os últimos 12 meses que antecederam a entrevista).” (FERREIRA, 2002: 144).

217 "A questão sobre em que medida a violência no Brasil se encontra situada ao nível das relações culturais e suas representações, podemos dizer, com uma margem considerável de segurança, que o grande dilema brasileiro é o da verticalidade de um autoritarismo que subordina os direitos à ordem hieráquica, tornando aquilo que é de todos em espaço de ninguém, consequentemente, fazendo com que noções que deveriam representar a todos, como a de cidadania, também percam o sentido.” (ADERALDO, 2010: 25).
} 


\section{Dimensiones histórico-sociológicas de la tortura en comisarías de Brasil: el caso Pernambuco}

valores de la corporación a los más nuevos ${ }^{218}$. La precariedad de la Organización en establecer valores "oficiales" favorece la creación de valores ocultos y de "héroes" desviados.

La iniciación a través de rituales en los que el "oficial" casi no participa y los hábitos y costumbres, aunque ilegales ${ }^{219}$, de los más viejos sirven como el "manual de supervivencia" ayuda a crear una organización con una doble moral: una para los discursos externos y otra para las prácticas internas. Eso hace con que la tortura, penalizada en ley propia y presente de modo destacado en la Constitución Federal sea flexibilizada en la práctica policial. En ese "mundo policial" la tortura sólo es crimen si es usada como fuente directa de "corrupción". Fuera de esa situación, la tortura será bienvenida, como señal de que quien la practica es un policía trabajador y esforzado.

Es interesante observar como los discursos que justifican la tortura siempre la atribuyen a la presión para obtener resultados, considerándolos derivados de una gestión por resultados, con metas a alcanzar, que viene siendo implantada en Pernambuco desde hace 4 años. No obstante, en las entrevistas donde hubo detalles respecto la práctica de la tortura pudimos percibir que no se trata de presión por resultados vinculados a metas, sino, la presión de los medios de comunicación y de los políticos cuando la víctima es de alto nivel social o en los casos de gran repercusión social. No podemos olvidar que la presión para alcanzar metas es algo muy reciente y todos los entrevistados no dudaron en decir que la tortura ha

\footnotetext{
$218 \quad$ "Nesse nível final é que a ideologia é internalizada como um conjunto pessoal de valores e crenças, o treinamento paga seus dividendos ao sistema, modelando as mentalidades para cumprir as ordens dos superiores, as estruturas organizacionais orientam as ações individuais e as estratégias de grupo se traduzem nas táticas individuais e nas autopercepções dos operárioss da violência”. (HUGGINS, 2006: 449).

219 "Ousamos até afirmar que, em segurança pública, lidar com milhares de homens com poder discricionário legal e autônomos, pelas circunstâncias dos locais de decisão, a tolerância pode significar consentimento (a disseminação de práticas nocivas, não exemplarmente punidas, arraiga a interpretação permissiva). (MORAIS, 2008: 99).
} 


\section{Dimensiones histórico-sociológicas de la tortura en comisarías de Brasil: el caso Pernambuco}

disminuido mucho. O sea, la presión por resultados como incentivo para la tortura llegó mucho tiempo después, y en el curso del declive de la práctica de la tortura. Otro aspecto a subrayar es que justo cuando los niveles de tortura eran más altos, la eficiencia de la policía estaba en los niveles más bajos ${ }^{220}$. Lo que podemos concluir es que la presión por resultados es sólo una "buena justificación” y que la tortura se produce como siempre ocurrió, por otras razones tratadas en esta tesis. Tampoco podemos vincular la disminución de la tortura con el aumento de la eficiencia de la policía, pues el aumento de la eficiencia está vinculado a un control más rígido, con metas a alcanzar.

Si parece que cargamos demasiado fuerza en el poder de la organización policial $^{221}$ para influir en sus integrantes vale la pena recordar la lección de Huggins (1986) cuando llama la atención sobre la dificultad de evaluar las fuerzas que actúan sobre los individuos que ingresan en la actividad policial, cuando están inmersos en una situación nueva e intensa como el trabajo policial. Como dijo Huggins ${ }^{222}$, nos falta la comprensión porque no hacemos el esfuerzo necesario para comprender el

$220 \quad$ "A crítica humanitária aos métodos violentos de trabalho da polícia não pode negligenciar os efeitos devastadores - do ponto de vista dos direitos humanos - da baixa efetividade das organizações do sistema de justiça criminal no combate à criminalidade: um deles é o estímulo a resoluções extra-legais de agressões criminosas: outro, é a facilitação de cruzadas morais de forte conteúdo autoritário: de um e de outro resultam no plano da psicologia social, o reforço de atitudes de cinismo e descrença frente à competência de modelos democráticos de resolução de conflitos". (PAIXÃO, 1997: 02).

$221 \quad$ Castell (1999) afirma que las instituciones son constituídas para imponer el cumplimiento de las relaciones de poder existentes en cada período histórico, incluso los controles, límites y contratos sociales derivados de luchas de poder.

222 "Muitas dessas forcas, isoladamente, são sutis e comuns em muitos cenários diários, mas quando combinadas e centradas em uma missão, em uma tarefa, em um alvo, são poderosas e, em alguns casos, explodem com consequência letais. Essa tendência a subestimar o poder de forças situacionais externas junta-se tipicamente à tendência a superestimar o poder da força das tendências ou da personalidade na orientação do comportamento. Esse par de atriuicões errôneas passou a ser conhecido como o "erro fundamental de atribuição" (fundamental attribution error), que dá muito pouco peso às variáveis situacionais e peso demais às variáveis pessoais (Ross, 1977)”. (HUGINNS, 1986: 423). 


\section{Dimensiones histórico-sociológicas de la tortura en comisarías de Brasil: el caso Pernambuco}

peso de usar un arma, de poder controlar la conducta de otras personas, de vivir con el riesgo constante de morir en el trabajo, la necesidad de establecer vínculos de complicidad ante una situación de gran riesgo, o morir durante un robo cuando se revela la identidad policial del agente. O incluso situaciones "más sencillas", como la presión para hacer cosas ilegales o callarse ante las acciones ilegítimas de los otros. 


\section{Dimensiones histórico-sociológicas de la tortura en comisarías de Brasil: el caso Pernambuco}

\section{LA MORAL DE LOS TORTURADORES}

La tortura es un tema tabú para los policías. Quizá por el miedo de ser punido, quizá para no disminuir el valor de su investigación y también por vergüenza de actuar como un criminal o cobarde. En las entrevistas percibimos una gran dificultad para tratar del tema. Desde aquellos que se rehusaron a hablar hasta aquellos que aceptaron hacerlo pero parecían tener un nudo en la garganta. Los eufemismos ${ }^{223}$ usados para sustituir la palabra "tortura" y los discursos vacíos antes de empezar las entrevistas son un buen indicativo de que se trata de un tema tabú. Muchos practican o asisten tranquilamente a sesiones de tortura, como se percibe en las entrevistas, pero casi nadie habla respecto a eso ${ }^{224}$. De ahí la importancia del análisis de discurso para extraer las explicaciones que buscamos. Nadie pronunció la palabra "machismo", pero esto está presente en muchos discursos. Pasó lo mismo con los conceptos de "violencia burocrática", "poder jerárquico" y "deseo de integrarse".

Cuando ya habíamos terminado el bloque de entrevistas, hubo dos nuevas oportunidades, con los comisarios $\mathrm{C} 14$ y C15. Las dos entrevistas fueron tan ilustrativas que nos llevaron a crear un capítulo específico para ellas.

Con el comisario C14 hablábamos de temas de la policía cuando mencionamos algún aspecto subrayado por uno de nuestros entrevistados. En ese momento C14 dijo: "tengo un caso que sería interesante para tu tesis... y para mí también, poder hablar de eso con alguien". Por primera vez éramos nosotros los

\footnotetext{
223 Cambios linguísticos tales como el uso de expresiones como "tirar serviço" o "trabalhar o preso", tiene um efecto de tornar más fácil transpor las barreras morales cambiando la naturaleza del daño.

224 La excepción son los discursos confidenciales entre torturadores, donde la práctica de la brutalidad aparece como ejemplo de virilidad y la relutancia, al contrario, como cobardía o afeminamiento.
} 


\section{Dimensiones histórico-sociológicas de la tortura en comisarías de Brasil: el caso Pernambuco}

invitados para la entrevista. Pero incluso con el deseo de hablar, C14 no era capaz de decir todo sin nuestra ayuda y era perceptible la dificultad física y mental para aflorar tal experiencia. Tuvimos que esperar unos siete minutos de una charla incomprensible antes de empezar a hablar del caso de tortura que fue más impactante para él. E incluso cuando había terminado, tuvimos que provocarlo para decir más.

C15 fue un caso distinto de todos. Como conocíamos su fama de torturador creíamos que íbamos sufrir la misma recepción de C10, otro comisario apuntado como torturador por algunos policías y que fue un poco violento con nosotros, pero fue muy distinto. Cuando lo encontramos estábamos en la posición de profesor en una asignatura de derechos humanos y él como alumno. Cuando faltaba una clase para terminar la asignatura propusimos la entrevista y él prontamente aceptó. Tan prontamente, que inmediatamente empezó a contar un "bizarro" caso de tortura. Tuvimos que detenerlo para esperar hasta la entrevista que sería dos días después. Mi grado de excitación era más alto que en todas las otras entrevistas pues sabía que él tenía fama de hablar de sus torturas. Con una hora y media de retraso él llegó y empezó a contar algunas de sus experiencias antes de contestar a la entrevista. Los 14 años como policía, viviendo en la ciudad más violenta de Brasil, no fueron suficientes para prepararnos para escuchar las cosas absurdas que C15 dijo. Eso fue un caso claro donde la realidad superaba la más osada ficción. C15 representaba un tipo que no buscábamos en nuestras entrevistas: el psicópata. Pero, estábamos interesados en la red de apoyo al psicópata y de cómo la corporación actuaba respecto a él. 


\section{Dimensiones histórico-sociológicas de la tortura en comisarías de Brasil: el caso Pernambuco}

\subsection{La "violencia burocrática", el "machismo", el deseo de integrarse y el "poder jerárquico"}

Como ya vimos anteriormente hay una serie de factores sociales, culturales y económicos que llevan a la práctica de la tortura. Dado que algunos factores fueron subrayados en otras investigaciones (HUGGINS, 2006; MILGRAM, 1974) ahora sin duda, debemos buscar patrones de comportamiento.

\subsubsection{La "violencia burocrática".}

Huggins llamaba la atención sobre las excusas dadas por los policías que torturaron en la Dictadura de 1964 en Brasil, utilizando el argumento de la "guerra contra los comunistas" 225 . Comparando las entrevistas ejecutadas por ella con las nuestras parece que sólo cambió el foco de la "guerra", ahora contra la delincuencia.

... La población es bombardeada con noticias de violencia todos los días y piensa o yo o ellos. Por eso aceptan que la policía sea tan violenta. Es como una guerra, donde todo vale." (C3). ${ }^{\text {cdxxxviii }}$

Es fallo del estado no poder capacitar a su agente de policía para que él consiga investigar a través de otros medios en los que no sea necesaria la utilización de la tortura. Si el Estado no cumple con su parte de ofrecer estos medios entonces tiene que al menos ser condescendiente para que la sociedad no quede expuesta a que ningún caso pueda cerrarse, a que ninguna investigación sea concluida... (C14). ${ }^{\text {cdxxxix }}$

225 "Os relatos de 'causa justa' legitimavam a violência ou para salvar a vida de um 'cidadão de bem', ou para 'salvar' o Brasil de um inimigo interno, sendo este último argumento menos comum do que o anterior”. (HUGGINS, 2006: 362). 


\section{Dimensiones histórico-sociológicas de la tortura en comisarías de Brasil: el caso Pernambuco}

Pero el punto más fuerte, tanto en la encuesta de Huggins, como en nuestra, es el discurso del "profesionalismo"226. Al hablar sobre el discurso de uno de sus entrevistados, que había torturado y matado en la dictadura de 1964, Huggins (2006) señalaba el perfil del 'torturador profesional', que sólo torturaba 'legítimamente,227 en el 'estricto cumplimiento del deber'. Podemos percibir el mismo en nuestras entrevistas donde qquien admite la práctica de la tortura la trata como algo necesario ante los desafíos del trabajo policial:

La institución quiere resultados, la institución quiere autoría, quiere materialidad. Lógicamente está en contra de la tortura, castiga a los torturadores, eso es evidente, como una institución legal, castiga, pero como te dice que "quiere esos resultados para ayer", y no te da recursos, implícitamente, tácitamente, te está dando un aval para torturar, con una pega: mira, quien coge la bomba eres tú. Y a veces el torturador es un torturado porque la tortura está no en la tortura física, pero en aquella tortura psicológica porque yo tengo una autoridad, y para preservar esa autoridad, ese plus, yo tengo que dar resultados... (A1). ${ }^{c d x l}$

(...) Bueno creo que si aquel investigador no usa la tortura comúnmente puede ser mal visto por los colegas y no ser considerado un buen investigador (...). (C14). ${ }^{\text {cdxli }}$

Entonces se veía que la única forma de obtener éxito en las investigaciones era con la práctica de la tortura. Y entonces te dabas cuenta de que no eras sólo tú él que lo estaba haciendo y que otras personas, principalmente las que se destacaban... Entonces medio

226 "O 'profissionalismo', a explicacão mais comum para a tortura e o assasinato, mencionava ordens e pressoes ocupacionais como causas das atrocidades.” (Idem: 367).

227 Ratton afirma que la permanencia de la violencia policial estaría vinculada al significado que tal violencia adquire en el trabajo policial: "violência como recurso instrumental e como recurso moral". La dimensión instrumental está relacionada con una técnica eficiente de investigación policial, especialmente si considerarnos la insuficiente preparación de los policías brasileños. La dimensión moral estaría justificada en el "combate ao crime, entendido como um mal social que cabe à Polícia enfrentar. Volta-se ao tema da Polícia enquanto lixeiro da sociedade, que para livrá-la da escória, cria uma auto-imagem de sacralidade de sua missão que permite a utilização da violência não só como recurso técnico e instrumental, mas como instrumento moral'. (RATTON, 2007: 146). 


\section{Dimensiones histórico-sociológicas de la tortura en comisarías de Brasil: el caso Pernambuco}

parecía que quienes no practicaban la tortura eran los comisarios que no querían nada con el cuerpo de policía... (C14). ${ }^{\text {cdxlii }}$

No. Yo creo que, a pesar de la política del resultado, el jefe prefiere a un policía que no torture. Lógicamente que sería medio mago... Entonces preferiría al mago, que consiguiese averiguar sin torturar... (C14). ${ }^{\text {cdxliii }}$

Exactamente, porque no se puede dejar de decir que existe una cierta eficiencia. Si no tuviera resultado, naturalmente acabaría por ser un medio obsoleto. Pero como hay eficacia con el uso de esa metodología aún sobrevive. (A1). ${ }^{\text {cdxliv }}$

Si ese equipo, con tortura o no, consigue los resultados a los que aspiran los superiores, va a ascender. Lo que importa son los resultados. (A1). ${ }^{c d x l v}$

El agente quiere verse reconocido por su comisario. Quiere que el comisario lo mire y le diga que él tiene un policía que le muestra resultados. "Yo tengo un policía competente; yo tengo un policía en el que confío, al que yo le voy a dar determinado caso y él lo va a solucionar para mî́. Entonces, el agente quiere tener esa relación con el comisario. Él quiere agradar al comisario, que el comisario se sienta bien trabajando con él... Entonces, la mayoría de los policías civiles, incluso yo, quiere hacerse un nombre en la institución, quiere ser reconocido. Cada uno usa sus medios para hacer eso. Unos usan la tortura, otros usan medios burocráticos. Tú quieres conseguir tu espacio en la policía civil... (A2). ${ }^{c d x v i}$

Entonces a priori era algo que me incomodaba, pero después pasó a formar parte de las funciones. En determinados casos específicos el uso de la fuerza era necesario para llegar a determinado fin. ${ }^{\text {cdxlvii }}$

Es interesante ver tal como hemos apuntado antes como se sustituye la palabra "tortura" por "tirar serviço" (algo como "sacar trabajo adelante"). Esa especie de eufemismo puede ser un signo tanto de una burocratización de la violencia, donde se diluye todo el valor peyorativo de una acción y lo sustituye por 


\section{Dimensiones histórico-sociológicas de la tortura en comisarías de Brasil: el caso Pernambuco}

conceptos usuales de "trabajo" y así disminuye la resistencia de los agentes para ejecutarlo:

(...) donde sólo hay un comisario con la mano larga para hacerlo todo, allí sí caería drásticamente. Caería drásticamente. $(A 1){ }^{c d x l v i i i}$

En realidad la palabra correcta, que era muy usada en la época, no es tortura, sino "hacer el trabajo" (tirar serviço). Esa palabra, tortura, nunca es usada. Esa palabra, tortura, viene de la época de la dictadura... Entonces, esa palabra, tortura, es muy usada por (los de los) derechos humanos. Ellos la usan mucho. Pero la propia policía no, desde que yo estoy dentro, nadie nunca la usó. Tortura a fulano, vamos a torturarlo, a mengano, no. Vamos a "hacer el trabajo" (tirar serviço). Entonces, los que usaban mucho esa palabra eran los militares, pero la policía de investigación, la judicial, no, nunca usó ese término. (A3). ${ }^{\text {cdxlix }}$

El eufemismo constituye, además, una huida psicológica del torturador para justificar o excusar su atrocidad:

Hoy ya lo encuentro, pero no existen los medios, los aparatos, ni el apoyo necesario... Uno lo intenta, pero la policía no te lo da... Entonces uno tiende a evitar llegar a aquel camino, pero es extremamente difícil porque el reproche permanece la propia, policía no quiere saber que has cambiado de mentalidad. No quieren saber de teoría, ni de filosofía. Quieren saber que tú no estás durmiendo. Quieren resultados. El reproche continúa y tú te encuentras en aquel túnel sin salida. Entonces es cuando pasa lo que está pasando con buena parte de los policías. Ellos entran, no están de acuerdo, y se largan... Tú no vas cambiar el sistema, ¿el sistema de la Policía Civil? No, no lo vas a cambiar. Entonces la única solución es que te largues. (A2). ${ }^{c d l}$

Desafortunadamente, por la falta de una prueba científica capaz de elucidar los crímenes... Seguramente, si disminuyera esa práctica violenta disminuiría la elucidación de los crímenes. (C14). ${ }^{\text {cdli }}$ 


\title{
Dimensiones histórico-sociológicas de la tortura en comisarías de Brasil: el caso Pernambuco
}

\begin{abstract}
Ningún. Yo no veo ningún gano. Aunque ya tenga practicado y obtenido éxito en diversas investigaciones a través de ese medio cruel, yo no veo gano ningún en la práctica de la tortura. Creo que los compañeros con seguridad pueden usar eses medios crueles con el objetivo de ascender profesionalmente... por el resultado que la tortura posibilita. Como el Estado no ofrece los medios (para hacer una investigación científica) y hace caso omiso con la práctica delictuosa... (C14). ${ }^{\text {cdlii }}$
\end{abstract}

En ocasiones se culpa de la tortura a las víctimas y se sugiere que si ellos dijeran lo que se les preguntaba nadie iba sufrir, y de no hacerlo, el propio criminal sabe que le toca sufrir (son las reglas del juego).

En las ciudades del interior, el criminal no tiene esa idea, entonces para él llevarse un palo de la policía es más que correcto, es el trabajo de la policía... (A2). ${ }^{\text {cdliii }}$

Y es como si el tío, hasta por estar obstinado en aquella práctica, hasta ya está acostumbrado, sabiendo que tipo la policía va pillar, va a pasar por aquello. CA6) ${ }^{\text {cdliv }}$

Mientras salga bien, tortura con la misma naturalidad que realiza una citación o registra una denuncia. $(\mathrm{C} 3)^{\text {cdlv }}$

Por supuesto. La propia sociedad comulga con el pensamiento de que hay que pegarle al criminal. Ya me ocurrió una vez que, una señora que había sido atracada, al descubrir que su nieto estaba involucrado en el crimen, me pidió que le diera una paliza. $(\mathrm{C} 13) .{ }^{\text {cdlvi }}$

Si no se consigue probar va a ser favorecido. Y hay personas que sólo funcionan a palos, es de la índole de la persona. No confiesa, de ninguna manera, sólo confiesa si se lleva unos palos. Pero desafortunadamente, o afortunadamente hoy en día ya no se práctica. (A3). ${ }^{\text {clvii }}$ 


\section{Dimensiones histórico-sociológicas de la tortura en comisarías de Brasil: el caso Pernambuco}

\subsubsection{El machismo}

Algunos entrevistados mencionan palabras que nos remiten a una posible manifestación de "machismo" o como prefieren algunos autores, una "masculinidad burocratizante" 228 . Sin desear profundizar en ese tema, aprovechamos para subrayar algunas situaciones que parecen buenos ejemplos de cómo tales creencias pueden llevar a violencia ${ }^{229}$. No pretendemos decir que esas construcciones de masculinidad establecieron determinados tipos de atrocidades, como la tortura, pero no podemos desconsiderar la importancia de la construcción de la masculinidad en América

228 "O intercurso real e retórico entre desempenhos de papéis de atrocidades, sobre os quais temos falado, também é sugerido em certa literatura norte-americana sobre violência policial, que a encara como oriunda da cultura do agente policial "macho". O policial "macho" - que evita tudo quanto seja "feminino" possui um "ar masculino de dureza”, demonstra segurança e autoconfiança firmes e "exibe uma aura de agressividade (e) ousadia" (Crank, 1998: 181) - é a fonte de grande parte da violência policial. Crank afirma que como tradicionalmente os policiais são originarios da classe operária, em que esse tipo de apresentação de masculinidade tradicionalmente recebeu "grande apoio", o "meio cultural" do agente policial aceita e recompensa largamente a masculinidade de "macho" operário (p. 181). Para receber as recompensas de seus iguais, o policial "macho" "tem que ser agressivo, (...) atacar primeiro e agir com vigor e violência para suplantar o adversário” (p. 181). Uildriks e van Mastrigt (1991: 160) afirma que a dureza, e ser um homem vigoroso nas circunstancias “certas”, aumenta o status da pessoa como bom "tira” entre os demais agentes policiais”. (HIGGINS, 2006: 253-254).

229 "Nas disputas de masculinidade que incluem competição, aviltamento de outros homens $e$ exigência de respeito, a tênue linha entre agressão masculina "normal" e violência física é facilmente ultrapassada. Na verdade, Ramirez afirma que "viver segundo as exigências da masculinidade significa assumir um comportamento autodestrutivo de violência de alto risco" (p.77). Como são poucos os homens que conseguem bom resultado em demonstrar constantemente sua masculinidade em um sistema de competição generalizada por recursos de masculinidade escassos e esquivos, a agressão transforma-se facilmente em violência”. (HUGGINS, 2006: 174-175). 


\section{Dimensiones histórico-sociológicas de la tortura en comisarías de Brasil: el caso Pernambuco}

Latina y en especial en el Noreste de Brasil, Región que acuñó expresiones como “cabra macho",230 (la versión brasileña para macho ibérico).

A4 habla del deber cumplido como si la tortura fuera un método imprescindible para la investigación y también asocia la tortura con la masculinidad:

La sensación del deber cumplido. La satisfacción de llegar con el resultado al jefe. A lo mejor quiere ser más policía, más hombre que el otro. $(\mathrm{A} 4)^{\text {cdlviii }}$

Porque también estaba aquel que era efectivo, era él el que decía: mira el primer golpe es mío y lo que pase yo cargo con ellos. Como sucedió en algunas situaciones y él aguantó, Sucedió en algunos casos... Y de gran proporción, y él fue macho y aguantó. (A1 ${ }^{\text {cdlix }}$

Los demás siguen en la misma dirección al asociar el rechazo de usar la tortura como algo femenino y al mismo tiempo asocia lo femenino a algo débil e incapaz para la actividad policial.

Ya, ya vi. Cambiaban de comisaría, decían, oye tú no sirves para el trabajo no, tú eres muy tranquilo, una chica, vete a la oficina, a buscar un trabajo administrativo. (A4) $)^{c d l x}$

Ya, ya lo vi. Cuando ellos son iguales, están practicando la tortura entre iguales y uno intenta no hacerlo, realmente eres tachado de cobarde, nenaza, o cualquier cosa de ese tipo. Hasta compañeros comisarios ya han tenido su masculinidad colocada a prueba por que en el momento en que todos agredían él se quedó fuera y esa es una práctica que realmente no debe ser aceptada, pero que ya presencié. (C14). ${ }^{\text {cdlxi }}$

Ya veo que eres un blandengue, ya veo que eres un flojo, tenías que ser un recluta. (A1). ${ }^{\text {cdlxii }}$

230 (...) “Que é do sexo masculino. 2 Forte, robusto, varonil.” - MICHAELIS). 


\section{Dimensiones histórico-sociológicas de la tortura en comisarías de Brasil: el caso Pernambuco}

Ya, ya... Pocos... porque en su mayoría practicaba (la tortura). Esos pocos no se mezclaban, eran considerados unos blandengues, un tipo que en vez de ayudar estorba, perjudica el trabajo de la policía, no es policía. Vete a ser profesor de ballet. Vete a otro lugar, no aquí a la policía. Tu perfil no es de policía. Has venido al lugar equivocado. Ve a la escuela a enseñar... era completamente excluido. (A3). ${ }^{\text {cdlxiii }}$

El director, que ya murió, me dijo una vez, chaval sólo tienes tamaño, fuerza y flojera. $\underline{\text { Para }}$ qué todos esos músculos si no sirven para pegar a nadie. $(\mathrm{A} 4)^{\text {cdlxiv }}$

$\mathrm{C} 1, \mathrm{C} 2$ y $\mathrm{C} 3$ asocian la tortura con valores, liderazgo y respeto profesional:

Están aquellos que participan directamente para mostrar al equipo que son unos tipos duros. Están aquellos que no tienen valor para hacerlo, pero quieren que los agentes lo hagan. Están aquellos que ni valor para hacerlo ni valor para asumir las consecuencias, entonces fingen que no saben... (C3). ${ }^{\text {cdlxv }}$

(...) lo hace para demostrar a la tropa que es un tipo que debe ser respetado porque él es capaz de hacer aquello. $(\mathrm{C} 1){ }^{\text {cdlxvi }}$

El buen torturador era también idolatrado y poderoso además de ser temido. Era reconocido como un hombre fuerte y muchas veces líder. $(\mathrm{C} 2)^{\text {cdlxvii }}$

Así como los policías usan la violencia como forma de fortalecimiento de su masculinidad, usan la tortura sexual como una forma para afectar a la masculinidad del torturado: 


\title{
Dimensiones histórico-sociológicas de la tortura en comisarías de Brasil: el caso Pernambuco
}

\begin{abstract}
El objetivo es desmoralizar. Porque en general esos criminales quieren ser muy machos. El tío que mata, que viola, quiere mostrar que es el "puto amo". Y la cuestión sexual es desmoralizante. Él prefiere que lo desangren, prefiere que le arranquen un ojo a que le metan un dedo por el culo. Porque eso para el grupo, el grupo no acepta que a su líder le hayan metido un dedo por el culo, que se lo hayan follado, que le hayan metido el dedo en el culo. Porque pierde la fuerza y el respeto en el grupo. $(\mathrm{C} 15)^{\text {cdlxviii }}$
\end{abstract}

Incluso conociendo experimentos que sugieren que hay diferencia en la práctica de la tortura entre hombres y mujeres (véase Stanley Milgran) la percepción de los policías es de que hay muchos más hombres torturadores que mujeres por el hecho de serlo en un grado exagerado. Una posible explicación para eso puede ser el bajo número de mujeres en la investigación, fruto del propio machismo de la corporación policial.

Según HUGGINS, los "hombres de verdad", de acuerdo con la expectativa de la masculinidad patriarcal occidental, deben ser capaces de dominar a algunos hombres y a todas las mujeres. "Teste perfeito da dominação masculina são os confrontos que implicam perigo ${ }^{231}$ - seja físico, social ou intelectual ${ }^{232}$ ". Podemos ver eso en los discursos de A3 y A4:

\footnotetext{
231 "Messerschmidt (1993) afirma que determinados tipos de violência masculina constituem na verdade uma representação pública de masculinidades que incentivam o respeito e o controle da situação. Quando o controle masculino é, direta ou indiretamente, contestado - como, por exemplo, quando um suposto ou possível perpetrador deixa de demonstrar "respeito" suficiente por um policial - pode-se esperar que ocorra violência. Concordantemente, Adler e Polk (1996: 409) afirmam que onde há uma afronta perceptível à "integridade pessoal [de um homem], [ao] orgulho e [ao] domínio do ambiente social", a violência masculina pode resultar de uma "justa fúria" (Adler e Polk, 1996: 399). Essa reação à falta de respeito de um suspeito foi mencionada com frequência pelos entrevistados por nós chamados de policias "personalistas". (HUGGINS, 2006: 176-177) 232 (Idem: 172-173).
} 


\title{
Dimensiones histórico-sociológicas de la tortura en comisarías de Brasil: el caso Pernambuco
}

\begin{abstract}
Lo echo de menos, lo echo de menos. Porque hoy..., voy a ser bien claro, la gente ya no respeta, la gente hoy en día llega a la comisaría creyéndose con derecho, con derecho, aunque esté equivocado. No respetan al policía de guardia, no respetan al comisario de guardia. 'Hable con mi abogado...' Cosas que antes no pasaban... El tío llegaba, y si llegaba aquí y subiese la voz: al calabozo, dos o tres días... Era una lección para que aprendiera... (A3). ${ }^{\text {cdlxi. }}$
\end{abstract}

Desgraciadamente esa es la verdad. En las chabolas es así, ellos sólo entienden a lo bruto. Si hablas educadamente se creen superiores, que la policía les tiene miedo. Que le sacan ventaja a la policía. Entonces, desgraciadamente así es la vida del policía trabajando en las chabolas. (A4). ${ }^{\text {cdlxx }}$

También C14 y C15 no dejan dudas que incluso cuando ya tenían toda la información necesaria para encarcelar al criminal ellos torturaban por la confesión, como un último golpe a "enemigo derrotado":

(...) En aquel momento la rabia se manifiesta, a pesar de no tener nada que ver contigo o con tu familia, pero a la hora de la práctica de la tortura el policía asume ese papel como si sí tuviera que ver con él. Entonces la no confesión que empuja a la tortura hace como si estuviera faltando al respeto a la autoridad del policía, como si no estuviera atendiendo a la fuerza impuesta por el policía, entonces eso lo hace muy violento y es común que los comisarios miren para otro lado o hasta teman intentar pararlo. Yo he visto situaciones donde inclusive me llamó un superior para intentar impedir una práctica de tortura que estaba sucediendo. Entonces el superior que estaba en el local y tendría, en principio, la responsabilidad directa de impedir que aquello estuviese sucediendo, Lo ves saliendo de una residencia donde estaban pegando a alguien con barbarie (...) y la propia autoridad, que comandaba la operación sale del interior de la residencia y te pide por amor de dios, vete hasta allí y ve si consigues para aquello. $(\mathrm{C} 14){ }^{\text {cdlxxi }}$

\subsubsection{El deseo de integrarse}

El deseo de sentirse integrado y no ser visto más como un policía "novato", hace que muchos acepten como algo natural comportamientos que antes repudiaban. La primera fase de su educación informal es perder su personalidad: él ya no tiene un nombre, es conocido por todos con el apodo de "novinho" (novato). No importa si 


\section{Dimensiones histórico-sociológicas de la tortura en comisarías de Brasil: el caso Pernambuco}

tiene 22 o 42 años, ni lo que hacía antes de entrar en la policía. Ahora es sólo un "novinho":

En la PM (Policía Militar). En la PM (Policía Militar) sí. Ellos decían: tú no sabes una mierda, no, novato. Tú tienes que aprender novato. Entonces siempre las broncas eran de ese tipo, de manera que me sintiese fuera del grupo. Ellos ponían el dedo en la llaga, porque quien es novato no quiere que lo llamen novato. Quieres ser parte del grupo, quieres ser parte importante del grupo, entonces cuando ponían el dedo en la llaga. Ya veo que eres un blandengue, ya veo que eres un flojo, tenías que ser un recluta. Entonces me tocaban el ego, de alguna manera me apartaban, y de cierto modo decirme apóyanos que tú eres del grupo. No sabes nada, tú no estás apto para ser policía. (A1). ${ }^{\text {cllxxii }}$

Cuando entré aquí, ya al principio, en el departamento yo era el fuerte y entonces el tío me decía, novato vas a pegar a fulano. ( A4). cdlxxiii $^{\text {. }}$

(...) No se mezclaban, eran considerados unos blandengues, un tipo que en vez de ayudar estorba, perjudica el trabajo de la policía, no es policía. Vete a ser profesor de ballet. Vete a otro lugar, no aquí a la policía. Tu perfil no es de policía. Has venido al lugar equivocado. Vete a la escuela a enseñar... era completamente excluido. (A3). ${ }^{\text {cllxxiv }}$

Quieres ser parte del grupo, quieres ser parte importante del grupo...”. (A1). ${ }^{\text {cdlxxv }}$

\subsubsection{El poder jerárquico}

Finalmente, examinamos el "poder jerárquico" que es otro aspecto que contribuye a la práctica de la tortura. No de forma directa, con los jefes diciendo a los subordinados que deben torturar, pero si de una forma indirecta, cuando dejan claro que quieren resultados a cualquier precio.

Podemos establecer una comparación entre los efectos de esta pulsión subliminal y los resultados de experimentos que buscaban llevar a personas a 


\section{Dimensiones histórico-sociológicas de la tortura en comisarías de Brasil: el caso Pernambuco}

situaciones límites de violencia. Los científicos intentaban simular ambientes que son usualmente escenario de violencia o llevaban las personas a los límites de practicar violencia a través del poder de mando de un supuesto jefe. Los experimentos contaban con actores completamente distintos: estudiantes, personas que estaban buscando trabajo... La idea era descubrir hasta qué punto personas "normales", comunes, podrían reaccionar de manera "normal" cuando eran sometidas a condiciones anormales. Es decir, ¿las personas "normales" podrían ser capaces de actos típicamente sádicos o "monstruosos"?

Para comprobar si era así los investigadores reclutaron principalmente estudiantes universitarios que no sabían el objetivo de la investigación. Los voluntarios fueron sometidos a situaciones que simulaban una prisión ficticia y a otros experimentos que tenían la falsa apariencia de servir para ayudar a otros estudiantes.

El primero ejemplo es el de la Stamford prison experiment, donde hubo un estudio simulado de la vida en una prisión. La idea era poner a las "buenas" personas en un mal sitio - escenario que simulaba una prisión.

Los universitarios, voluntarios, que fueron bien evaluados, es decir, considerados normales después de una serie de exámenes clínicos, psicológicos, entrevistas, históricos, respecto a su pasado, fueron designados, aleatoriamente, para trabajar como guardias o encarcelados. Si en el inicio del trabajo los estudiantes, "guardias" o "encarcelados", no diferían en nada, al fin del experimento las diferencias eran muy expresivas.

Huggins $^{233}$ (1986), al tratar del tema, recordaba que aunque nadie haya recibido instrucciones de cómo actuar en sus nuevos trabajos, todos empezaron a

233 Os carcereiros desumanizavam os prisioneiros de muitos modos, punindo-os $e$ atormentando-os. Durante os longos turnos da noite, os carcereiros aliviavam seu tédio atormentando os prisioneiros, que tratavam como "brinquedos". Alguns dos rapazes escolhidos por ser normais, comecaram a agir sadicamente com os prisioneiros, aparentemente tendo prazer com 


\section{Dimensiones histórico-sociológicas de la tortura en comisarías de Brasil: el caso Pernambuco}

"entrar" en sus roles. Tal vez por lo que habían visto en películas o libros sobre la vida en la prisión. El experimento que había sido proyectado para durar dos semanas, tuvo que ser interrumpido después de seis días, pues la prisión se había vuelto demasiada "verdadera". En tan sólo seis días los guardias ya eran demasiado autoritarios y algunos hasta sádicos, mientras los encarcelados eran pasivos y totalmente sumisos. Algunos, elegidos por su buena salud física y psicológica - en el role de encarcelados - tenían niveles de estrés tan elevados que salieran del programa antes del final, algunos a partir de 36 horas del inicio. Sus colegas guardias ya se sentían tan violentos y agresivos que se estresaban con el límite establecido por el director de la prisión (Zimbarbo) para que no empleasen violencia física contra los encarcelados.

Otro ejemplo fue el desarrollado por Stanley Milgran (1974), donde creaba un escenario de autoridad. Invitó estudiantes de la Universidad de Yale, que serían los "profesores", a un experimento respecto la ayuda para mejorar la memoria de "estudiantes". El experimento consistía en aplicar descargas cada vez que los "estudiantes" no consiguiesen recordar su lista de actividades. Las descargas iban de 15 vatios (sin peligro) a 450 vatios (muy peligroso). Los "estudiantes" que debían recordar tal lista eran actores y la verdadera intención del investigador era verificar hasta qué punto la gente podría obedecer ciegamente las órdenes superiores. Los

sua inventiva crueldade. À medida que se desenrolavam os processos de desindividualizacão, desumanizacão e descomprometimento moral, já não importava aos carcereiros que estivessem "apenas" participando de um experimento como outros rapazes colegas seus que haviam sido aleatoriamente designados a representar "prisioneiros". No fim, os carcereiros percebiam os prisioneiros como "perigosos" - a tal ponto que decidiram que alguns precisavam ser mantidos acorrentados ou em "confinamento solitario” por mais tempo do que a duracão máxima permissível - e torturavam os prisioneiros para mantê-los na linha ou obrigá-los a submeter-se à sua autoridade. Alguns carcereiros achavam que estavam em uma prisão de verdade, ainda que gerida por psicólogos e não pelo Estado. As distorções da realidade chegaram a tal extremo que os "prisioneiros" esqueceram-se de que poderiam dizer: "Vou sair deste experimento". Ao invés disso, trabalharam nos limites do sistema e só solicitaram livramento condicional, que foi negado. (HUGGINS, 1986: 472-473). 


\section{Dimensiones histórico-sociológicas de la tortura en comisarías de Brasil: el caso Pernambuco}

estudiantes, "profesores", que eran invitados para aplicar las descargas no sabían de las verdaderas razones del experimento, tampoco de los actores. Ellos eran informados que los "estudiantes" que estaban sometidos al experimento estaban atados a una silla eléctrica y cada vez que se equivocaban recibían descargas, aplicadas por los "profesores". Los "estudiantes" estaban en una sala al lado de la de los "profesores", pero los "profesores" no podrían verlos, solamente escucharlos a través de un aparato intercomunicador. La norma era que, cuanto más grandes los errores, más grandes debían ser las descargas. Como los “estudiantes”, actores, estaban instruidos para jamás aprender todo el contenido, las descargas eran cada vez más grandes y los gritos de los "estudiantes" cada vez más altos. Cuando algún "profesor" se preocupaba con los gritos muy altos que eran escuchados por el aparato y preguntaba se debía continuar, llegaba la figura de la autoridad - con un chaleco blanco de laboratorio - e, insistía que el profesor debería honrar su contrato verbal y continuar enseñando a los "estudiantes". Después de los 375 vatios se escuchaba un grito y un ruido como un cuerpo cayendo en el piso. En ese momento la mayoría tenía miedo de continuar pero llegaba la autoridad y exigía continuar el experimento, pues de lo contrario el "profesor" podría ser punido. Cuando algún "profesor" preguntaba quién sería responsable en caso el "estudiante" llegase a morir, la autoridad decía que asumiría toda la responsabilidad.

Después del experimento, Milgran invitó cuarenta psiquíatras a presentar una estimativa de probabilidad de cuantos "profesores" llevaron la experiencia al nivel máximo, aplicar descargas cada vez mayores en un alumno que ya estaba inconsciente, pudendo llevarlo a la muerte. Los psiquíatras llegaron a la estimativa media de que menos del $1 \%$ de los "profesores" llegarían a ese nivel del experimento - solamente los sádicos tendrían ese tipo de comportamiento, creían. Pero, en 


\section{Dimensiones histórico-sociológicas de la tortura en comisarías de Brasil: el caso Pernambuco}

realidad, fueron el $65 \%$ de los estudiantes de Yale los que llegaron a ese nivel ${ }^{234}$. Pocos llegaron a desobedecer o desafiar a la autoridad. Prácticamente todos discordaban verbalmente, pero obedecían.

Milgran continuó con la experiencia llegando a más de mil participantes. Usando distintas variables, en algunas experiencias el nivel de obediencia del "profesor" llegó a 10\% y en otras al 90\%. El nivel máximo fue obtenido cuando el "profesor" miraba a un colega ejecutar el comportamiento deseable.

Uno de los paralelos que podemos hacer entre el estudio de Milgram y el caso de nuestros entrevistados es el referente al del poder de la autoridad. Los jefes exigen los resultados y los policías torturan para alcanzarlos o alcanzarlos de manera más rápida. Milgran también usó la demostración de un colega para obtener el grado máximo. Según nuestros entrevistados, primero el tema de la tortura es banalizado en la Academia de Policía, después, cuando empezaban a trabajar observaban como los policías más expertos torturaban y eran obligados implícita o explícitamente a callarse, después son empujados a hacerlos ellos mismos como una prueba de que eran "uno de ellos".

Medio siglo después, Jerry Burger - Universidad de Santa Clara - repitió el experimento de Milgran y comprobó que aún es válido. La principal diferencia fue que Jerry paraba el experimento en los 150 vatios, mientras que en el experimento de Milgran, que fue muy criticado por eso, iba hasta los "450 vatios", generando demasiado estrés en los voluntarios que aplicaban las descargas (los que recibían

\footnotetext{
234 "A falha dos psiquiatras em prever com precisão o resultado das demonstracões vigorosas de Milgram é um exemplo do 'erro fundamental de atribuicão' (Ross, 1977). Culturas individualistas centram-se tipicamente no ator e desprezam o cenário: assim, os efeitos são atribuídos às características pessoais de um agente e raramente às características comportamentais de cenário de uma acão. $O$ treinamento de psiquiatras, como o de muitos outros profissionais da área médica, centra seu olhar científico e clínico sobre problemas nas psiquês individuais e distantes dos determinantes ambientais do comportamento. Em contraposicão, uma orientacão de saúde pública busca os vetores ambientais que moldam as patologias individuais”. (HUGGINS, 1986: 456).
} 


\section{Dimensiones histórico-sociológicas de la tortura en comisarías de Brasil: el caso Pernambuco}

eran actores). Jerry invitó 29 hombres y 41 mujeres para repitieren el experimento de Milgran y constató que 7 de cada 10 voluntarios estaban dispuestos a aplicar descargas más grandes que 150 vatios.

En un dado momento, ponían un voluntario que sabía lo que estaba ocurriendo junto con los demás para negarse a aplicar las descargas. Incluso con esa negativa, el $63 \%$ de los voluntarios decidieron seguir aplicando descargas más grandes que 150 vatios. Tampoco había diferencias de comportamiento entre los voluntarios de 20 a 81 años de edad. Pero, la diferencia entre el número de personas que iban allá de los 150 vatios fue significativamente más pequeña.

Otra experiencia interesante para nuestro estudio muestra como la deshumanización de las víctimas puede actuar como una variable que lleva a un aumento de la violencia. También usando el uso progresivo de descargas como una experiencia "pedagógica” y contando otra vez con la participación de estudiantes, los investigadores Bandura, Underwood y Fromson (1975), añadieron una nueva variable: los comentarios respecto a los "estudiantes" que sufrirían las descargas. Los asistentes de los "profesores" hacían comentarios favorables, neutros o desfavorables a los "estudiantes" y los resultados correspondían a los comentarios: los que recibían buenos comentarios, descargas menores; malos comentarios, descargas mayores ${ }^{235}$.

235 "Os autores concluíram que a 'desumanizacão favorecia as justificativas de auto-excusa que, por sua vez, associavam-se ao aumento da punição’ (Bandura et al., 1975: 253). Esses resultados demonstram o poder desinibidor da rotulacão sobre o comportamento agressivo quando despoja as pessoas de qualidades humanas. Parece ser o que ocorre, mesmo sem a força adicional de justificações externas ou óbvias atitudes negativas pré-existentes relativamente à posição social das vítimas potenciais”. (HUGGINS, 1986: 461). 


\section{Dimensiones histórico-sociológicas de la tortura en comisarías de Brasil: el caso Pernambuco}

\subsection{El discurso más explícito de tres torturadores}

Abajo siguen tres relatos de distintos entrevistados con contenidos más rotundos que las demás entrevistas. Fueron relatos espontáneos y con fuerte emoción. Podemos decir con tranquilidad que fueron los momentos más difíciles para los entrevistados, aunque hablar del tema era visiblemente desagradable para todos.

La razón de dar una importancia más grande a esos relatos es que en tales casos, al contrario que en los demás, tenemos declaraciones explícitas de la práctica de la tortura. El contenido es tan absurdo que no parece real. Por eso hemos transcrito fragmentos de entrevistas más extensos. Ellos también contestaron a las preguntas usadas para los demás (véase anexo).

El primero es el discurso de C14, caso 1, comisario que se ofreció para darnos una entrevista cuando supo que hacíamos un doctorado respecto el tema: "Tengo un caso que creo sería interesante para tu tesis... y para mí también poder hablar con alguien sobre eso". El discurso de C14 tardó un poco en producirse tan grande era su dificultad de hablar. En los cinco minutos iniciales de grabación escuchamos a C14 hablar de la importancia de nuestro trabajo y otras cosas sin mucho sentido, mientras tomaba valor para empezar a hablar.

El segundo momento fue en la entrevista de A1, cuando contó un caso en que su equipo cogió un sospechoso y, durante la tortura descubrieron que se habían si equivocado de persona. Coincidentemente, pues trabajaban en comisarías distintas, otro entrevistado (A2) también participó del mismo trabajo y dio un relato más completo, caso 2.

El tercero, C15, fue el caso más dramático y al mismo tiempo era el entrevistado más tranquilo. Aunque usaba algunas muletillas lingüísticas, "certo", 


\section{Dimensiones histórico-sociológicas de la tortura en comisarías de Brasil: el caso Pernambuco}

"né”, a cada tres palabras, él, al contrario de los otros no tenía vergüenza de lo que contaba, al contrario, parecía sentir placer en recordar cada caso.

\subsubsection{C14, el casi arrepentido}

Fue el propio C14 el que se ofreció para una entrevista. Era obvia la tensión de mantener el secreto, aun a pesar de que varios policías hubieran participado de la tortura junto a él. Él mismo dijo que estaría bien hablar con alguien.

Caso 1:

"Me marcó mucho en virtud a la formación que tuve (...) que no tenía en mente ningún tipo de violencia en nuestra formación. (...) siempre fui contrario a la violencia (...) siempre me mantuve distante de cuestiones policiales, nunca me vi dentro de la policía, mucho menos en aquel aprendizaje horrendo que es de la década de los 60, que es del régimen militar. Esa policía que nosotros aprendimos a reconocer era una policía ostensiva, una policía castigo, meramente de castigo. Y eso siempre estuvo muy lejos de mi formación. Y casualmente caí, ¿vale?, en el ramo del Derecho (...). Y ya en la universidad tuve la oportunidad, ¿vale?, de presenciar, raramente, pero tuve la oportunidad de presenciar ese horror que es la práctica de la tortura en nuestro país. A través de algunas prácticas como estudiante de derecho en algunas comisarías de compañeros que ya ejercían la profesión, ¿vale?, y entonces yo pasé a ver los más diversos tipos de tortura, cuando compañeros, tales compañeros que me llevaban a conocer un poco lo que era ser comisario de policía, simplemente se emborrachaban para agredir a presos indefensos que estaban allí. Presos de delitos menores, que no representaban ningún peligro para la sociedad, pero que por haber delinquido estaban presos y servían como instrumento de tortura para comisarios alcohólicos que hacían eso por placer, simplemente. Y, por casualidad, y accidentalmente acabé en el cargo de comisario de policía, donde siempre me mantuve distante de eso, casualmente saqué unas oposiciones públicas. Y nunca siquiera me había imaginado como comisario de policía. Entonces yo mismo me sorprendí, realmente, al asumir el cargo. A encontrar en el ejercicio del cargo de comisario de policía 


\section{Dimensiones histórico-sociológicas de la tortura en comisarías de Brasil: el caso Pernambuco}

que podía ser más de lo que realmente el cargo suponía, los derechos y los deberes que el cargo impone. Entonces en el afán de dar una respuesta a la sociedad nos olvidamos de todas nuestras enseñanzas de vida, nuestra educación de familia humilde de campo y pasé a querer dar una respuesta para la sociedad de alguna manera como la poca experiencia que yo tenía, era aquella experiencia obtenida a través de los momentos en la ciudad de provincias donde un conocido era comisario de policía, o sea, a base de tortura. Entonces no satisfecho con las investigaciones, realizadas, aunque satisfactorias, que serían por si solas capaces de llevar a la condena, pero teníamos realmente ganas de a través de cualquier medio obtener confesiones y para satisfacer nuestro ego, costara lo que costara, ¿no?, inclusive por medio de la tortura. Es uno de los hechos que marcaron mi vida y que no solo denigre la carrera de comisario, si no sobre todo el tipo de ser humano que yo siempre tuve la oportunidad de ser por mi educación familiar... En determinada situación, donde un crimen bárbaro asustó a una determinada localidad en la que yo vivía, un estudiante universitario fue bárbaramente asesinado por una venganza, donde un determinado elemento planeó toda su muerte y de forma bárbara lo ejecutó en el auge de sus 23 años. Llevando ya de 2 a 3 años de investigaciones, cuando la sociedad clamaba realmente por justicia, los padres de la víctima realizaban manifestaciones, convocaban consejos, enviaban a los gobernantes de nuestro estado, eran múltiples reproches, ¿vale?, entonces nos sentimos en la obligación de concluir ese caso con el máximo de pruebas. Y así fue durante 3 años, un bello trabajo, que fue estropeado al final, cuando tuve la oportunidad de tener, trabajando conmigo, personas especializadas en un departamento, especialistas de nuestra policía, ¿no?, personas acostumbradas a trabajar bajo el régimen de la tortura, esas personas podrían haberme dado apoyo ponerse de mi parte. Ya con el caso concluido y con todas las pruebas capaces de llevar a indiciar al sospechoso, nosotros, en esa acción realmente tenebrosa de mi vida, lo cogimos bajo la sombra de la noche, cuando salía del trabajo, lo metimos en un saco de especias, fácilmente vendido en los mercados públicos, lo colocamos dentro del maletero de un vehículo y lo llevamos hasta otro Estado, dentro de una plantación de caña (canavial) y allí lo sometimos a todos los tipos de tortura posibles, desde la tortura física, vehemente, psicológica, ¿vale?, con disparo de arma de fuego cerca de su oído, sacos, la utilización de sacos para evitar que respirara, además de varios puñetazos y patadas y la víctima resistiendo a todo esto, a toda esta serie de torturas es un caso realmente para avergonzar a cualquier ser humano y mucho más a un profesional que pretende ser respetado. Después de toda esa serie de torturas el sospechoso, mismo siendo el autor del crimen, consiguió, heroicamente, sufrir 


\section{Dimensiones histórico-sociológicas de la tortura en comisarías de Brasil: el caso Pernambuco}

todos estos tipos de agresiones sin ablandarse. Realmente, aguantó todo y a todos, todas la agresiones sufridas sin confesar, cuál sería su mayor intención, ese hecho de él no confesar inclusive nos llevó a una sospecha que ya no existía más, cara a los innúmeros elementos y pruebas obtenidos durante toda la investigación. Entonces llegamos realmente a desconfiar que todo el trabajo se había ido por el desagüe, por las torturas que habían sido practicadas no haber surtido efecto. Y entonces, volvemos, con él, y lo tiramos en la calle como se tira una bolsa de basura, y lo dejamos en la calle, si se muere, que se muera, porque en aquel momento la ceguera del acto insano nos llevó a no tener respeto siquiera por la vida humana. Lo tiramos en la mitad de la calle a su suerte y él consiguió escapar. (...) $)^{\text {cdlxxvi }}$

¿Hubo violencia sexual?

Todos los tipos de actos fueron practicados contra él, ¿vale?, en cuanto a violencia sexual, hubo penetración con instrumentos en su ano, luego, ya con el objeto sucio, con heces, fue colocado en su boca, ¿vale?, realmente fueron actos practicados, y, además de los chorros de sangre que escupía, tenía que tragársela mezclada con tierra inclusive, hacía con que él se la tragase de nuevo, su propia sangre mezclada con arena, es duro hasta describirlo." (C14 entrevista Marzo/2012). ${ }^{\text {cdlxxvii }}$

Después de haber escuchado este sorprendente relato, pensamos que se trataba de un policía arrepentido. Pero, poco después, cuando nos encontramos con él nos confirmó que se sentía mejor y, aprovechó para contar otro caso en que había torturado a otro inocente. En ese segundo encuentro él ya estaba mucho más tranquilo y confesó que no había parado de torturar, pero cada vez más lo hacía con más cuidado y "sólo" cuando le parecía "imprescindible". 


\section{Dimensiones histórico-sociológicas de la tortura en comisarías de Brasil: el caso Pernambuco}

\subsubsection{A2, el indeciso.}

Durante la entrevista de A2 había momentos en que aseguraba que jamás torturaría otra vez y algunos momentos después admitía que sí podría volver a torturar. La duda estaba presente a lo largo de toda su entrevista.

Caso 2:

"Hubo un caso que me hizo volver a pensar esa cosa... Hubo unos robos a personas muy influyentes y empezamos a investigar. Monitoreamos 8 blancos, durante varios días. Entonces sucedió lo que llamamos de "fallo". La gente había sido monitoreada, con escuchas telefónicas y se descubrió la casa del jefe y que era una persona violenta, tenía armas... Entonces llamé a un equipo que sabía de que modo trabajaban, si necesitaban usar la violencia ellos la usaban, y les dije: mirad, este es el blanco principal, él tiene armas, es violento, entonces traernos resultados. Yo os estoy dando el blanco y quiero resultados. Entonces el equipo usó la fuerza y no encontraron nada. Echaron la puerta abajo, todo aquello y no encontraron nada. Entonces trajeron al blanco al punto cero, a la comisaría, le puse las escuchas telefónicas para que las oyese, y pasó algo que no había visto nunca, cuando la violencia es empleada con una finalidad. Porque generalmente un bandido que está siendo acorralado, tiende a entender, muchas veces, como si aquello fuera necesario. Él es el criminal y la policía trabaja de esa manera entonces merece llevarse aquella paliza, él merece llevarse aquellos puñetazos, para él, forma parte del servicio de la policía y es el riesgo que corre. Todo se ha descubierto y ahora él va a pagar por ello. Sólo que lo que pasó aquel día me dejo impresionado: porque cuando el blanco llegó y yo le dije tú eres fulano de tal y tengo tu conversación grabada... tu nombre es fulano de tal... le puse la escucha y me dijo - ese es mi nombre, pero esa no es mi voz -. ¿Ese es tú nombre? ¿Cómo que esa no es tu voz? Tengo testigos, escucha... ¿Como que no eres tú? Estas mintiendo descaradamente. Puede 'trabajar' el blanco. Y él fue trabajado. Y cada vez que se llevaba un golpe me miraba a los ojos y me decía: - yo te perdono, por lo que estás haciendo, pero soy inocente -. Y cada vez que me miraba y decía eso yo comentaba, chaval, nunca vi en mi vida a ningún criminal hacer esto. Ellos se quedan callados, hay unos que son de sangre fría, ni te miran, ni dicen nada... Pero cada vez que él se llevaba una zurra, él nos miraba a todos y nos decía: - yo os perdono a todos pero soy inocente -. Hasta que yo paré y le dije a mi equipo vamos a parar. Hay algún 


\section{Dimensiones histórico-sociológicas de la tortura en comisarías de Brasil: el caso Pernambuco}

error, esto no es normal. Y entonces dije: llamad al resto de la banda y vamos a confirmarlo con ellos. Cuando la banda llegó dijeron que nunca habían visto a aquel tío... Entonces el policía que había trabajado ese día (A1) vino y me dijo: Hace 4 días que no consigo dormir, por que cada vez que voy a dormir veo a aquel señor, diciéndome que me perdona. ¿Y qué? Llegué a la conclusión que no quiero más de eso. Estoy perdiendo mi paz... No sólo no quiero más de eso, como que perdí el interés de ser policía... Eso me quitó mi paz... Ya vi eso muchas veces y he descubierto que eso quita la paz. Que al final, por más que llegues al fin específico, por más que te sientas satisfecho por que llegaste al resultado, vas viendo que los medios que usaste te van quitando la paz, por eso no vale la pena... Entonces ese fue un acontecimiento que cambio la visión que yo tenía sobre la tortura. Fuimos injustos, aunque con esa operación recibimos elogios del jefe de policía, del gobernador, por que fue una gente muy influyente la que había sido robada...Yo_ya he presenciado mucha, mucha violencia, pero nunca había presenciado esa reacción de la víctima... Y ni siquiera había sido nada muy exagerado, hubo muchos puñetazos, golpes, empujones, pero nada excesivo. (A2). ${ }^{\text {cdlxxviii }}$

Este es el relato de un policía que aún no había cumplido tres años dentro del cuerpo y ya había visto "mucha, mucha violencia", y que consideraba la práctica de la tortura como un "trabajo", algo que "es parte del trabajo de policía” y que el delincuente sabe que ese es el "trabajo" del policía y por eso merece ser torturado cuando es capturado. Que esa es la función de un policía para obtener resultados, es decir, capturar delincuentes y "promover la paz" en la sociedad.

Quizá pueda parecer un relato de un psicópata, pero puedo garantizar que parecía una persona igual a tantas otras con las que he convivido en la escuela o en la universidad. Era muy extrovertido, me impresionó la facilidad con que hacía amistades en la ciudad donde estábamos trabajando y nos conocimos. Estaba en el final de su licenciatura en Derecho, tenía novia, era un "excelente" policía (siempre con disposición para trabajar) y expresaba de forma muy clara sus ideas. 


\section{Dimensiones histórico-sociológicas de la tortura en comisarías de Brasil: el caso Pernambuco}

Según A1, después de esa situación permaneció cinco noches sin dormir bien. Siempre veía la imagen del torturado diciendo: "yo os perdono a vosotros, pero soy inocente".

Después de ese caso A1 llegó a la conclusión de que ya no quería trabajar en la policía, su viejo sueño, y estaba estudiando para trabajar en la Justicia. Aun así, A1 confesó la práctica de la tortura después de ese caso y decía que estaba en contra, pero que la practicaría en otras ocasiones, si fuera necesario... Se mostraba completamente confuso...

"Mira... A día de hoy estoy contra todo y cualquier tipo de tortura. Pero hace poco ha sucedido un crimen de gran complejidad, involucrando un mismo lugar, un lugar deshabitado, un homicidio y una violación, y la única víctima y testigo era la persona violada. Lo único que ella recordaba eran pequeñas características del acusado, algunos tatuajes. Y salimos a la búsqueda del acusado hasta que lo encontramos. ¿Cómo solucionar esto? ¿Y como reaccionar frente a tanta seguridad de que era él realmente ? evidentemente no iba a confesar. Y hubo tortura y él confesó, dando hasta detalles. Que hasta la tortura se hizo en el local del hecho. Y él confesó bajo presión de tortura. Y estoy seguro que si no hubiese sido hecho de esta manera él no hubiese hablado . (...). Lo que yo llego a entender...la tortura es un crimen y como todo crimen, tiene sus excepciones (...) yo creo que en los casos que... es difícil porque todo va a depender del caso en concreto... Existen situaciones en las que se necesita de la materialidad del crimen y en el caso del... Pero volviendo a la respuesta yo estoy en contra y declaradamente contra cualquier forma de tortura. Ya no hay más tortura en mi presencia ... es complicado... en fin, particularmente, yo creo que en los casos que yo creyese que fuese a necesitarla mucho que pensase que así tendría aquella información y pudiese obtenerla yo torturaría sin ningún problema.” (A1). ${ }^{\text {cllxxix }}$ 


\section{Dimensiones histórico-sociológicas de la tortura en comisarías de Brasil: el caso Pernambuco}

\subsubsection{C15, el sádico}

Esta fue la más inesperada y la más excitante entrevista conseguida para esta tesis. De tanto escuchar referencias a la actuación violenta del comisario C15 nosotros imaginábamos que él se mostraría contrario al hecho de que estábamos realizando entrevistas respecto a la tortura. Ya habíamos tenido una mala experiencia al intentar entrevistar a otro conocido torturador. Pero esta vez fue muy diferente. Él fue muy amable, hablaba con buena disposición, la entrevista duró casi 2 horas y media, y creemos que sentía placer en relatar sus experiencias. Al principio pedimos que nos relatara los casos que más habían llamado su atención y sólo después de escuchar algunos casos iniciamos la entrevista formal.

Abajo, C15 relata un caso en el que se tortura a un inocente, sospechoso de haber practicado un robo a un banco. Había imágenes de la cámara de seguridad que no eran de buena calidad y mostraban a los criminales con fusiles y ametralladoras. Un informante (otro criminal) llamó la policía para decir que los criminales que robaron el banco estaban bebiendo delante de una vivienda...

"Entonces llegó el momento en que una persona fue detenida , ¿verdad?, involucrada, ¿verdad?, también en un asalto a un banco, ¿verdad?, entonces el informante dijo que ellos estaban delante de la casa, están bebiendo, ¿verdad?, en frente, están en la Colina de la Concepción, en lo alto de la colina, ¿verdad?, están con armas, ¿verdad?, entonces fuimos hasta el lugar, había tres personas, ¿verdad? , tres macarras allí bebiendo, ¿verdad?, y fueron detenidos, ¿verdad? ,el agente los trajo a todos los metió en el coche, ¿verdad?, y fue, fue para el embalse de Apipucos cerca de una casa abandonada, y allí, los llevamos, el comisario de sección estaba presente, y esas personas estaban esposadas, todas, ¿vale?, con un saco en la cabeza para que no identificaran a nadie. Y empezamos por el más joven, ¿verdad?, la gente decía que él era uno de los más activos en los asaltos, ¿vale? Y él fue colocado, ¿vale?, colgado, atado por las piernas, ¿verdad?, fue colocado un punto de apoyo para él cerca del embalse y él metido dentro del agua, ¿verdad?, y sacado para que dijese donde estaban las 


\section{Dimensiones histórico-sociológicas de la tortura en comisarías de Brasil: el caso Pernambuco}

armas, ¿verdad? Él, ya a las tantas, después de haber bebido tanta agua, estaba cabeza abajo, él nos dió dos pistolas que estaban dentro del coche, en la puerta (... - detalles de donde estaba el arma). Pero lo que interesaba no eran aquellas pistolas, lo que interesaba era la ametralladora, el fusil, ¿verdad?, y el dinero robado, ¿verdad?, Y en ese caso, ¿verdad?, después nos dimos cuenta, que él estaba con otra persona que era su hermano, e hicimos lo mismo, ¿verdad?, delante de él, ¿verdad?, y ninguno de los dos soltó más que eso. ¿Vale? Entonces ellos se desmayaron, dos veces, ¿vale?, sangraron mucho por la nariz y por los oídos, Pero llegamos a la conclusión de que él no era la persona del atraco, ¿vale? Ellos realmente habían hecho algunos atraco, ¿vale?, se recuperaron pistolas y tal, pero ellos no habían participado en aquel atraco. Entonces ellos todavía pasaron un día en el calabozo, ¿verdad?, de la comisaría, entonces fue preferible dejarlos en libertad sin hacer ningún procedimiento porque ellos estaban con muchas magulladuras, con muchos moratones. Y como ellos no eran conscientes, ¿verdad?, de quienes los estaban torturando, ¿verdad? Entonces fueron dejados en el pueblo, en una aldea cercana, y no tuvimos más contacto con ellos. Eso es un aspecto negativo. El informante, el tío que dijo eso, también tuvo lo suyo, por haber dado la pista equivocada. Y este fue uno de los casos que no tuvo éxito. No tuvimos lo que nosotros queríamos... Y dando seguimiento a esa investigación de ese banco..." $(\mathrm{C} 15){ }^{\mathrm{cd} l \mathrm{lxx} x}$

Sus relatos confirman algo que ya habíamos escuchado con los otros entrevistados: la tolerancia de los policías hacia la tortura. En este caso había un superior jerárquico, en otros, policías militares o guardias de prisión, incluso un juez.

Entonces fuimos al local y detuvimos a cuatro. Entonces fuimos a una finca en los alrededores de Recife, donde un político conocido nuestro tenía varios bichos en casa, ¿verdad?, y él tiene una serpiente, él dice que es la reina de las serpientes. Una serpiente venenosa que está dentro de un cuadrado de madera y tiene una parte de cristal en el frente , un cristal grueso, (...) y allí, en una de las dependencias de la finca, todos los policías encapuchados y él fue colocado sentado en una silla, atado, ¿verdad?, y su pie iba a ser colocado dentro de la caja. le dimos a la cobra unos golpes con un palo para que tomase la posición de ataque, inclusive fue realmente bonito, porque ella se enroscaba, se preparaba y las dos presas salivaban de rabia, y fue colocado el pie, y él estaba con fichas de dominó 


\section{Dimensiones histórico-sociológicas de la tortura en comisarías de Brasil: el caso Pernambuco}

dentro de la boca, varias fichas de dominó dentro de la boca. No podía hablar, y no impedía la respiración. Si hubiésemos metido un trapo llega un momento que se cansa y la respiración con trapo húmedo tapa la respiración, lo deja sin aire y puede hasta morirse sin dar la información. (...detalles de la eficiencia del dominó) pero la desesperación y el pánico de los otros, ¿verdad?, entonces, cuando vio la serpiente no se lo creyó y fue mordido por la serpiente. Y fue observado cada cinco o diez minutos y decía ya no consigo ver, ¿verdad? No veía y se dio cuenta de que tenía fiebre alta. Y el segundo, viendo todo eso, no lo aguantó, vio que no era una broma, y dijo que las armas habían participado en el asalto y que todas las armas estaban guardadas cerca del (...detalles de donde estaban las armas y como fueron recuperadas). Y fue todo recuperado, inclusive de varios otros atracos, fue una incautación buena, fue repasado a las autoridades. Ellos fueron pillados ¡in fraganti! Al que le había mordido la serpiente fue hospitalizado, no llegó a morir, le reventó todo el cuerpo, fue hospitalizado. Y dijimos que él había huido en la selva, la selva es realmente grande, es peligrosa. Dijimos que se había fugado y que fue hospitalizado, pero él murió siendo atendido. Él murió. los otros, estaban la hermana y la madre de dos de los que estaban en el lugar, También fueron detenidas, pero en las negociaciones, ¿verdad?, ellos prefirieron no acusar ni a la madre ni a la hermana del otro prefirieron soltarlas para que ellas no dijesen nada sobre la tortura, fue negociado, se dijo que habían sido detenidos con las armas pero tampoco había imágenes suyas ya que ellos estaban encapuchados, entonces van a decir que estabais con las armas, pero vuestro abogado va a defenderse diciendo que no erais vosotros. Entonces ellos aceptaron, fueron detenidos y acusados por tenencia de armas y uno murió en el hospital y ellos ya están todos en la calle, robando de nuevo, porque ya aparecieron algunas imágenes (...detalles). ${ }^{\text {cdlxxxi }}$

Al ser preguntado cuantas veces utilizó una serpiente para torturar un sospechoso, dijo: el mismo método fue usado varias veces, pero sin la picada.

¿Y el dueño de la serpiente no se quejó? 


\section{Dimensiones histórico-sociológicas de la tortura en comisarías de Brasil: el caso Pernambuco}

El dueño de la serpiente es un político, (...) y él es un sádico. Él participa, él lo presencia, y lo encuentra maravilloso, vibra, ¿vale?, ha conseguido ahora, hace poco otra serpiente, tiene una coral pequeña, le han informado de que existen dos tipos de serpientes corales: la verdadera, y la falsa, que no tiene veneno, ¿vale?. Entonces, fue interesante que para saber si era la verdadera ¿vale? realmente le mordió, se sintió mal, no llegó a morir, ¿vale?, fue atendido en su casa por un médico al que avisaron y le aplicó una inyección de no sé qué, el enfermo estaba encapuchado, con un saco en la cabeza, entonces no vio quien había sido. Y realmente él no murió. Y como tenía un hijo involucrado, ¿vale?, entonces no detuvieron a ninguno de los dos. Entonces no contó nada de la tortura porque si él hablara de la tortura él tendría que decir que él había cometido un homicidio, él mató al tipo que le ponía los cuernos a su hijo, entonces a cambio de silencio él también fue puesto en libertad y no dijo absolutamente nada. Y el político (...) conserva esa serpiente, él tiene serpientes más grandes, él tiene un estanque con, no sé si es un cocodrilo o un caimán que no crece mucho...

Hay otro caso interesante (...) y el empresario estaba pidiendo que fuese investigado, habían matado a su hijo un chaval de 16 años, él le disparó en la cabeza (...) Entonces nosotros empezamos a trabajar en esa investigación hasta que él fue identificado, nosotros nos lo llevamos a una zanja en el (...) y él fue llevado allí y el empresario también fue llevado hasta allí para verlo, él quería ver al tipo. Entonces fue llevado hasta el lugar, ¿vale?, y él mismo le arrancó todas las uñas con un alicate, de las manos y de los pies, vale? Él quería verlo, le dijo tú primero vas a sufrir, le enseñó el retrato de su hijo al criminal, al asesino y asaltante, le arrancó todas las uñas, y lo interesante es que no satisfecho con esto él llevó un soplete y lo encendió, y quería grabar la acción, y nosotros le dijimos mira no es conveniente grabarlo, más pronto o más tarde eso cae en manos de alguien, ¿entiendes? Y encendió el soplete y le tostó todos los dientes, era interesante, el tipo perdía el conocimiento y se despertaba, entonces él le echaba un líquido desinfectante en la zona, entonces el tipo mejoraba, él le tostó todos los dientes, ¿vale?, le quemó todas las manos, el pene, ¿vale? , (...) el tío estaba trastornado. Y después lo quemó enterito con el soplete. Enterito. Él es un gran empresario en el área de (...), tiene varias empresas, lo que importa, es un tío muy poderoso. Pero, lo interesante es que nosotros pensábamos que esto le fuese a dar más tranquilidad, vivía tan perturbado que quería vengar a su hijo, y después de haberlo vengado se quedó aún más perturbado de lo que ya estaba... ${ }^{\text {cdlxxxii }}$ 


\section{Dimensiones histórico-sociológicas de la tortura en comisarías de Brasil: el caso Pernambuco}

El entrevistado percibe con claridad que la práctica de la tortura fue responsable del desequilibrio mental del empresario que torturó al hombre que había matado su hijo, pero no se pone en la misma situación. Preguntado respecto al evidente desequilíbrio del empresário, C15 lo atribuyó a la tortura: Foi pelo que ele fez, porque ele tinha necessidade de conversar constantemente, e perguntando se fez errado, que sonhava com o filho dizendo...

Está comprobado por otros que participaron, que muchas veces yo los alerto, Eh déjalo eso para nosotros, deja eso para la policía, "no, pero yo quiero participar" y cuando participa la persona no vuelve nunca a ser la misma. Ya no es la misma. Hasta inclusive delincuentes que torturaron y que hoy nosotros vemos que él no tuvo estructura emocional para soportar lo que hizo. (...) ${ }^{\text {cdlxxxiii }}$

¿Y los policías?

Varios policías tampoco tienen estructura emocional. Hay policías que hoy están en recursos humanos, hay policías que han desarrollado una especie de tumor, a veces en la garganta, tumor en la cabeza, tíos que llegaron a tener enfermedades que nosotros vemos que es más a causa de los remordimientos, a causa de un arrepentimiento, que inclusive se transforma, a uno le quedó constatado que el médico le dijo usted no tiene nada, usted está creando esa enfermedad. Hay que tener aguante ${ }^{\text {cdlxxiv }}$

¿Tuvo a alguien en su equipo que sufrió de problemas psíquicos derivados de la práctica de la tortura?

Hay uno que recientemente pidió la jubilación. Es interesante que él se está viendo un bulto, está internado, haciendo tratamiento psicológico, porque está viendo a las personas que él torturó. Aunque nosotros ya le hayamos dicho, al principio, pero tío es así, Tú no lo hiciste 


\section{Dimensiones histórico-sociológicas de la tortura en comisarías de Brasil: el caso Pernambuco}

por hacerlo, por maldad, por instinto. Tú lo hiciste buscando una información sobre una cosa que tú ya sabías. Ninguno está haciendo adivinación. Nadie ha cogido a un tío, mira ese tío es un sospechoso, es un tío así, nosotros no sabemos si él ha participado o no, entonces vamos a salir de dudas. No. Eran personas que eran entregadas o por parientes, o por informantes, o por enemigos de su propia banda. Que eso pasa a menudo, el tío se molesta dentro del grupo y es humillado por un líder o por alguien de la banda. Y él va, y se chiva, no sale del grupo, muchas veces él viene detenido también, pasa por alguna sesión de tortura, y es apartado, y listo, sólo para justificar su detención y él los entrega por algún motivo. Haber recibido menos que los otros, haber sido humillado dentro del grupo. Hubo uno que se enamoró de una de las mujeres de la banda y ella también se enamoró de él, sólo que el líder, era un homicida (...), y lo interesante es que él humillaba al compañero. Él sabía que estaban juntos, que estaban enamorados, pero el tío solo para desmoralizarlo, le decía: ¡ehh! tu mujer va a acostarse hoy conmigo (...) Entonces Diego llevado por los celos vino y confesó. Él confesó abiertamente que había participado en varios atracos, que formaba parte de una banda (...) Y a esas personas conseguimos detenerlas y ellos pasaron por la misma sesión (...) Él fue llevado al embalse la y dentro del embalse había una placa de cemento que habría sido un tiempo atrás algún puente alguna cosa que hicieron en el embalse y quedó aquella placa en aquel lugar. Entonces él fue colocado en aquella placa y todos nos quedamos esperando que subiese la marea. Y el agua subiendo, subiendo, y nosotros íbamos a salir y le dije, ahora eres tú y tu suerte, la marea va a subir, no vas a aguantar, si no hablas vamos a tu casa y traemos a alguien de tu familia y le va a pasar lo mismo que a ti. Entonces realmente confesó (... detalles de los objetos robados y como fueron encontrados). Él fue preso y lo interesante es que hoy él es una persona completamente transformada. Yo hablo con él en la cárcel, está casi saliendo en libertad, es una persona evangélica (...) pero lo dejo todo dentro de la cárcel. ¡Es increíble! Su conducta y mandó llamar a su hermano más joven que estaba en el crimen, se juntaron, conversaron, y él consiguió transformar al hermano que estaba en el crimen (...). Ese es el único caso, nosotros no conocemos otro caso. (...) Pero él ha mostrado en los últimos tres años un comportamiento completamente diferente, pero su comportamiento es interesante. Hoy en día él hace un trabajo muy interesante.... nosotros vemos en él tanta sinceridad... ${ }^{\text {cdlxxxv }}$ 


\title{
Dimensiones histórico-sociológicas de la tortura en comisarías de Brasil: el caso Pernambuco
}

\begin{abstract}
¿No se preocupa por si el empresario acusa a todos los responsables?
Es, pues si, para contarlo, él tendría que entregar a su hija, entregar a su esposa, porque ellas estuvieron en el lugar, ellas presenciaron muchas escenas. Entonces yo creo que incluso en un acceso de locura él se bloquearía para contarlo. Para contarlo tendría que estropear su vida, empresario de éxito, un tío con mucho orgullo, muy prepotente. Tenía aquella sed de venganza, pero después de la venganza el tío perdió el equilibrio, estaba arrepentido, pero ya no podía hacer nada. Él no lo podía contar, ¿vale? Hoy en día su hijo asumió la dirección de las empresas, ¿vale?, y él hoy está "hecho un mal de Alzheimer" casi que colocado, casi espontáneo, porque él insiste en no acordarse de nada, en no reconocer a las personas (...), se aisló del mundo... ${ }^{\text {dllxxxvi }}$
\end{abstract}

Abajo el comisario habla con admiración de la resistencia física de un torturado:

Una salud de bicho, porque "El Cabeza" (apodo de un delincuente) se había llevado palos, había llevado saco, "El Cabeza" tomó aceite quemado, fue enterrado vivo. Y que salud de bicho, media hora desenterrado y parecía que "El Cabeza" no tenía nada. Que salud de bicho. cdlxxxvii

El comisario habla con orgullo por el hecho de que es llamada por políticos, miembros del Gobierno, fiscales y jueces. Contó un caso de un juez que pidió “dar un jeito" (eso puede referirse a una brutal paliza e incluso hasta la muerte) a un hombre que había utilizado lenguaje soez con su esposa y de un asesor de un ex gobernador. 


\section{Dimensiones histórico-sociológicas de la tortura en comisarías de Brasil: el caso Pernambuco}

Hubo situaciones destacables. La casa de uno de ellos, una persona del gobierno, fue asaltada y se llevaron un ordenador portátil en que había información muy importante que estaba en el pen drive que estaba en la máquina. Y le rindió a la persona que entró en la casa, se llevó dinero, muchos dólares, se llevó un arma se llevó todo eso. Entonces el tío entró en pánico. Entonces uno de los asesores dijo mira él paga bien. ${ }^{\text {cdlxxxviii }}$

Lo curioso es que confiesa que trabaja en el área de responsabilidad de otros comisarios y llega a decir que trabaja a medias en su área específica de actuación y a medias en otras áreas.

¿Estabas actuando en tu área de jurisdicción?

No, no, no, no. Trabajaba en una comisaría en la que no tenía nada que ver. Nosotros, mejor dicho, nosotros éramos el 50\% actuábamos en la zona, mantenía tal, porque esa pasión por la policía, no tenía hora, no tenía día ni semana, vamos a hacer redadas, tele denuncia, entrar en la casa de un sospechoso, entrar en casa de delincuentes y, por los general funcionaba, porque nosotros sólo presionábamos en los locales minados, puntos calientes... Y, el $50 \%$ está pedido. (...). No. No tenía nada que ver con nuestra área. El personal dijo coloca al comisario en el circuito para ver si se recupera. ${ }^{\text {cdlxxxix }}$

¿Hubo alguna recomendación interna indicándolo a usted para este trabajo?

Exactamente. Ese asesor él con una persona de la central. Y él dijo: Mira yo no voy a meterme, pero puedes mencionar mi nombre que él va a entender (...). Y lo interesante es que en ese robo se llevaron un balón de fútbol americano, autografiado por varios jugadores americanos, era una reliquia y se lo llevó esa persona que ni sabía lo que se estaba llevando. Entonces comenzamos la investigación. Sólo que por el lugar de acceso, sólo podía haber sido alguien que conociera la casa. Primero era alguien que conocía la casa. Pero las cámaras de seguridad no mostraron nada, esa, era la casa del representante del gobierno no mostraron nada. Entonces la conclusión fue que tenía que haber sido alguien de la casa. Entonces por eliminación, solo quedó un chaval que era una especie de casero, pero era de confianza de la 


\section{Dimensiones histórico-sociológicas de la tortura en comisarías de Brasil: el caso Pernambuco}

familia, entonces nos preguntamos ¿de quién podemos desconfiar? Mira, de nadie. ¡Eh! ¿Y ese chaval? Ese chaval había llegado con seis años y ahora tenía diecinueve. Entonces era el tipo que si quisiera hacer algo, él lo podía hacer abiertamente, podía “dar un palo”, porque él tenía la contraseña, el político no tenía control de todas sus cuentas, él cogía la tarjeta del político, sabia la contraseña, el consultaba el saldo, entonces era un colega de confianza. Nosotros dijimos hay que empezar por él. Entonces OK, cuando él salió para ir hacia su casa, lo pillamos. Entonces nos lo llevamos, ¿vale?, ha Jaboatão, a una casa de un vigilante que era amigo nuestro, vivía sólo, y allí se quedó sentado, atado a la silla, le dimos un baño, un buen baño de agua, desnudo. Y el tío encogía las dos piernas de frío entonces nosotros le dábamos cada chispazo que el tío temblaba desde el pelo hasta las uñas de los pies y se golpeaba, esposado. Entonces cuando se recuperó entonces nosotros dijimos coge a su hermana, que vive con él y lo llevamos para casa, ella lo sabe todo. Cuando él vio que íbamos a por la hermana, entonces él dijo que iba a colaborar, pero no dio pie con bola. Entonces nosotros lo cogimos y fuimos a la casa de la hermana con la que vivía. Y se buscó de todo, se revolvió todo. La hermana se llevó muchos golpes en la cara, muchas tortas. se quedó en la silla sentada desnuda, ella avergonzada, entonces a la hora de llevárnoslos, encontramos drogas, encontramos robo de electricidad, vas a ser procesado "in fraganti", encontramos "hierba" en el cuarto de él, listo va a ser procesado todo mundo. Ella también por la cantidad. Y a la hora de irnos un policía ilumina con una linterna, debajo de la cama, y dice, no aquí no hay nada, sólo hay un balón viejo, encima es oval que ni sirve para jugar. Entonces ya saliendo nos paramos: balón viejo, oval, ¡saca ese balón! cuando él empujó el balón, mira fue una alegría, todo el mundo dio un grito de alegría porque era el balón americano, autografiado. Entonces él abrió el juego (... detalles del robo y los materiales recuperados).Nosotros lo recuperamos, sólo que del hombre del gobierno no recibimos absolutamente nada, ni un apretón de manos, ni un gracias $(\ldots)^{\text {cdxc }}$

¿Para qué tipo de delitos te sientes “obligado” a usar la tortura?

Patrimoniales. Patrimoniales. Y robo en la casa del tipo, y el tipo se lleva el coche y el portátil, principalmente el Portátil/notebook, se lleva móviles de última generación. Más recientemente hubo unos políticos que discutieron a causa de un robo (...). ${ }^{\text {cdxci }}$ 


\title{
Dimensiones histórico-sociológicas de la tortura en comisarías de Brasil: el caso Pernambuco
}

\author{
¿Dónde vienen las órdenes para que actúes en casos que no pertenecen a su \\ área de actuación?
}

Noventa por ciento de las peticiones vienen de personas de la cúpula, ¿vale? Vienen del juez, Ministerio Público (equivalente al tribunal supremo), políticos. Que vienen, cuando no son ellos los que vienen directamente, conocen a alguien, a un asesor, tal, ese es la petición de fulano y nosotros vamos y la atendemos. Y el $99,9 \%$ ha sido con éxito. Hay resultados, porque cuando se coge a una persona para hacer conjeturas, lo que nos deja más tranquilos con relación a esos métodos es porque nosotros no lo hacemos, como muchos hacen, ¿entiendes?, que es conjeturar, mira es un tipo del área, aquél tío es un ladrón entonces aquél tío debe conocer a alguien que sabe sobre el asunto y que pueda darnos alguna información para coger al colega. Entonces vamos a usar el método, el tío va a llevarse palos, el tío va al saco, va al baño, el tío va a beber aceite. Que interesante es la piedra de azufre que nos dijo el médico. Coges una piedrita de azufre, la metes dentro del agua y ella va filtrando el agua. Ella va filtrando el agua y es efervescente. Una piedrecita de azufre dentro del organismo, por menor que sea, entra en efervescencia y va dentro del hígado. Aquellos polvitos se infiltran dentro del hígado. Y él dice que se va comiendo el hígado por dentro, ¿entiendes? Entonces, a los treinta días como máximo, como máximo, el tío piensa que es cirrosis, piensa que es cáncer, piensa que es otra enfermedad, no aparece en el diagnóstico. El azufre no es diagnosticado dentro. Pero va comiéndoselo por dentro y el tío va a dar en óbito sin ninguna duda, ¿entiendes? Entonces... si algo sale mal, dale la piedrecita de azufre y espera, que son dos meses, aunque él denuncie, está en fase de interrogatorio policial, pero él no llega a sentencia, porque a la hora de declarar en el juicio él ya ha muerto en algún lugar y la falta de pruebas, sólo basada en interrogatorio policial, con un buen abogado, ¿claro?, como muchos han dicho la persona no está probado nada. Y también causa disturbios, delirios, ya que una parte va al cerebro y aunque la persona denuncie, ya a partir de aquél momento, o un día después él empieza a tener ideas y frases inconexas, el azufre causa eso. Entonces lo dijo un médico, un médico de un gran hospital, y es un investigador preparado, él lo necesitó y él dijo usa eso en el tío que algo va a decir cuando le preguntes es casi como una hipnosis el tío va a decir, que él tiene lapsus en la memoria que él dice cosas sin raciocinar, sin nada, ¿entiendes? (... detalles minuciosos de la recuperación de los bienes ) Entramos en la casa, 


\section{Dimensiones histórico-sociológicas de la tortura en comisarías de Brasil: el caso Pernambuco}

hizo una revista, el hijo de la mujer ya había estado encarcelado, le mostramos las fotos del GPS y le dijimos, mira el móvil está aquí. El chaval dijo mira hace bastante tiempo que no hemos hecho eso... Entonces es la señora, es la madre, entonces la madre va al saco y entonces es cuando le colocamos el saco a la madre, y a los hijos ${ }^{\text {cdxcii }}$

Mejor vamos a comenzar la entrevista formal, pues tus anécdotas parecen no tener fin.

Eh, colega, no tiene fin no. ${ }^{\text {cdxciii }}$ 


\section{Dimensiones histórico-sociológicas de la tortura en comisarías de Brasil: el caso Pernambuco}

\subsection{Conclusión}

Después de pasar por la Academia, el nuevo policía va a trabajar en una comisaría donde sus colegas de trabajo empiezan a llamarlo "novinho" (novato) de forma peyorativa, como alguien que no sabe cómo trabajar, sin experiencia y que quizá no sirva para el trabajo policial. Para aquellos que se niegan a practicar la tortura aún tienen que enfrentar las dudas respecto su masculinidad, además del "mito", o no, de que quien delata a un colega que practicó la tortura puede pagar con la vida. El deseo de integración, el miedo y los reproches sucesivos de los más viejos y expertos lo empujan a ver las atrocidades con normalidad e incluso son inducidos a practicarlas y amenazados si divulgan lo que ven. En ese momento hay "rituales", en que los "novatos" son llevados a practicar las torturas como prueba que pueden ser policías. Cuando se niegan, son llamados "maricones", "débiles", "no policías". Incluso son amenazados con enviarles a lugares indeseables. Cuando los más viejos perciben que pueden fiarse en ellos, finalmente, los "novinhos" pasan a ser más respetados $\mathrm{y}$, poco a poco a ser integrados en sus respectivos equipos. El paso siguiente es la percepción de que los que consiguen resultados más rápidos son elogiados y ascendidos más rápido en la carrera; también son seducidos por recompensas o sobornos de las víctimas de robos y hurtos cuando consiguen recuperar sus bienes.

Según los experimentos relatados arriba, personas comunes o "normales" sometidas a determinadas condiciones sociales acaban por reaccionar de una manera violenta, en total contraste con sus comportamientos anteriores al experimento. Es decir, sus patrones ético-morales son alterados por las condiciones socioambientales. 


\section{Dimensiones histórico-sociológicas de la tortura en comisarías de Brasil: el caso Pernambuco}

Al negar la universalización de derechos ${ }^{236}$ y apoyar las estrategias de "guerra contra la delincuencia", se defiende la permanencia de prácticas autoritarias, que históricamente se han revelado ineficaces, porque no cuidan de dos aspectos fundamentales: la manutención del orden público no es conseguida a través del exterminio de los que son diferentes y la democracia no se consolida por el uso de la violencia $^{237}$.

También detectamos diferencias generacionales de valores entre policías. Los más antiguos sostienen que no se puede "trabajar bien" con "tantos derechos humanos". También tienen un discurso vocacional fuerte y, en general, hablan de que hoy en día no se respeta a la policía (masculinidad personal). Los más jóvenes tienen una visión más pragmática y afirman que es posible investigar sin torturar, pero dicen que les faltan los medios y el tiempo, pues hay mucha presión por conseguir resultados. Tienen muchas ganas de obtener resultados (masculinidad burocrática). Para ellos la razón para ingresar en la policía fue la búsqueda de dinero y seguridad; mientras tanto hacen otro concurso- oposición para un empleo donde puedan ganar más y correr menos riesgos.

236 "A discussão sobre direitos humanos está imbricada de noções sobre quem tem direito aos direitos e esta remete ao universo da justiça. Até recentemente, poucos autores (Deutsch, 1975 e A3ster \& A3ster, 1975) estavam alertas para o fato de que os princípios de justiça não abrangiam todos os cidadãos de uma sociedade. O pressuposto da inclusão de todos mascarava a existência de grupos que são colocados à margem dos procedimentos de justiça e, contra os quais, sequer se identifica-se a injustiça. A este processo denomina-se exclusão moral. A exclusão moral é definida como ocorrendo 'quando pessoas que normalmente obedecem às leis aceitam ações bárbaras contra indivíduos ou grupos' (Deutsch, 1990)". (CARDIA, 1995: 19-20).

237 "As críticas às atuações das polícias não se baseiam só nos flagrantes casos de atuação violenta e arbitrária contra os membros das classes populares, mas também pela fraca atuação ostensiva da polícia na proteção dos moradores de classes populares. Segundo o Mapa de Risco de violência de São Paulo (CEDEC, 1996) as maiores taxas de homicídios verificam-se em bairros pobres, sendo que a prioridade dos órgãos de segurança - deslocamento de homens e viaturas - no município de São Paulo está no combate aos crimes contra o patrimônio que ocorrem nas áreas com as melhores condições sócio-econômicas." (FERREIRA, 2002: 59). 


\section{Dimensiones histórico-sociológicas de la tortura en comisarías de Brasil: el caso Pernambuco}

Las entrevistas de los agentes de policía no sólo coinciden con las entrevistas de los comisarios, sino que refuerzan la hipótesis de mecanismos institucionales que operan a favor de la pervivencia de la tortura. Lifton (1986) ya señalaba el poder que corporaciones especializadas pueden ejercer sobre los que trabajan en ellas.

Podemos destacar tres categorías de fuerzas que actúan sobre los policías: la memoria histórica, que ayuda a deslindar entre categorías de ciudadanos y no ciudadanos, así como ayuda a moldear la figura represiva del policía; los procesos sociológicos, dando cuenta de cómo el individuo reacciona a las influencias de su medio, tales como la cultura corporativa, presión de la sociedad, percepción de la delincuencia; los procesos psicológicos, tales como machismo, autoritarismo, sadismo. Estas fuerzas pueden actuar en conjunto o aisladas, moldeando los valores, las ideas, percepciones y comportamiento del policía.

También fueron identificados algunos factores incentivadores de la violencia: a) consideraciones morales anteriores que son ignoradas (crear nuevas moralidades); b) la obediencia ciega es determinante; c) Las víctimas son deshumanizadas; d) La responsabilización personal y social son neutralizadas. Se activa la "falta de compromiso moral". Los estudios sugieren que un poder situacional puede inducir a personas buenas a comportarse de una manera que violenta sus patrones morales y éticos anteriores. 


\section{Dimensiones histórico-sociológicas de la tortura en comisarías de Brasil: el caso Pernambuco}

\section{CONCLUSIÓN GENERAL}

La policía tiene como función primaria, al menos en un plan moralmente aceptado, hacer cumplir las leyes o normas legales de una sociedad y de detener, llevar antes al juez a quien las incumple. Pero, a veces con la excusa de cumplirla, otras veces, para sacar provecho propio, es la primera en infringirlas, funcionando como un obstáculo más para la consolidación del Estado Democrático de Derecho. Eso puede empeorar incluso cuando se añade a la noción prevalente de hacer justicia con las propias manos, o a todo costo, con posturas de racismo y prejuicios, además de la ignorancia sobre la función político-social de la policía.

Podemos pensar el problema de la tortura como fruto de la acción de un conjunto de personas de psicopatía o sadismo extremado, "los monstruos" o "la manzana podrida". Esa es la interpretación más cómoda para todos pues pune solamente a ciertos individuos y exculpa al sistema que permite la tortura y aporta la red de apoyo a los torturadores ocultando cualquier culpabilidad analítica o legal sistémica. Eso favorece la perpetuación de la tortura, pues la naturaleza global de su violencia permanece fuera de los registros en las discusiones académicas o políticas.

Tenemos que preguntarnos constantemente por qué personas que entraron en la policía sin historial de violencia, una vez que pertenecían a esa organización, empezaron a torturar. No porque eran unos psicópatas, pues éstos son la excepción, sino porque percibirían que ese era el comportamiento esperado por sus pares, apoyados en una red de discretos colaboradores: sus jefes, los fiscales, los jueces, los médicos forenses, los periodistas, las ONGs, la población.

Cuando un comisario usa la tortura como forma de investigación, tal práctica es evidente para otras secciones del sistema criminal: declaraciones (indagaciones) 


\section{Dimensiones histórico-sociológicas de la tortura en comisarías de Brasil: el caso Pernambuco}

basadas sólo en la confesión, inmediatez de las investigaciones, aporte de pocas pruebas técnicas, seguidos relatos de violencia, y el propio deseo de contar como se elucidaron algunos casos (demostraciones de poder o "masculinidad"). Esto significa que los médicos forenses cierran los ojos a las evidencias de tortura, los fiscales no escuchan los relatos de las víctimas, los abogados de los torturados actúan como si eso no fuera tan importante, las víctimas aceptan la tortura como inevitable, los

jueces cierran el proceso sin una palabra sobre la tortura... Para entender por qué la policía tortura, necesitamos, principalmente, comprender por qué la sociedad permite que ellos torturen.

Cuando nuevos policías ingresan en la Institución aprenden, a través de las experiencias vividas, que la organización a cual pertenecen puede premiar a aquellos que consiguen resultados mediante la tortura, haciéndolo en silencio y de manera casi invisible, lo que todos esperan de ellos. Al garantizar que la ciudadanía no tenga por que ensuciarse las manos, tales policías son los verdugos "invisibles", y cuando son descubiertos se transforman en los “monstruos". Por supuesto que esto no sirve como justificación para sus actos, y además los policías también obtienen ventajas con la práctica de la tortura.

Aquellos que no aceptan practicar la tortura se sentirán obligados a tolerarla, pues, perciben que es mejor camino aceptar que sus colegas la practiquen que enfrentarse el coste de rebelarse contra esa "tradición".

Una de las explicaciones para esa paradoja es el nivel muy elevado de delincuencia. Pues, cuando las expectativas en relación a la seguridad no son mínimamente atendidas, es decir, cuando el fenómeno de la violencia no se maneja de forma satisfactoria y no es previsible que aquellos que utilizan la violencia sean castigados en consecuencia, la sociedad empieza a perder la confianza en sus instituciones, pudiendo los individuos intentar resolver sus problemas de seguridad en privado o apoyar los excesos e ilegalidades. Es algo parecido con lo que ocurrió 


\section{Dimensiones histórico-sociológicas de la tortura en comisarías de Brasil: el caso Pernambuco}

en el período de la Dictadura. Hay una "guerra", ahora no contra los comunistas sino contra los criminales. Y eso parece funcionar como una justificación para los policías que cometen atrocidades. El problema es que tal "guerra" no se da en toda la sociedad, ocurre sólo en el margen de la línea de pobreza. Hay un mundo "normal" arriba, con las leyes más avanzadas y, otro "mundo" donde tales leyes carecen por completo de valor.

En ese sentido, el personal policial que perpetra la tortura trabaja de dos maneras: de forma directa, cuando la policía es contratada para trabajar con entidades de seguridad privada, torturando o exterminando para garantizar la seguridad de sus empleadores; de forma indirecta, cuando en su trabajo como policía, ellos atienden solamente a algunos estratos sociales. Evidencia de eso es que la preocupación con la tortura sólo llegó a formar parte de la agenda pública cuando la clase media estuvo entre las víctimas (Dictadura de 1964). Después de la democratización, la condena de la tortura perdió su fuerza, al menos en los discursos.

En el presente trabajo de tesis encontramos evidencia de que la policía sigue a usar hoy la tortura en Brasil como método de investigación en las comisarías, sólo para sospechosos pobres y excluidos, y encontramos algunas explicaciones para la persistencia en dicha barbarie.

La breve revisión histórica efectuada buscó demostrar la debilidad del argumento, muy común en los medios académicos, de que la policía tortura hasta la actualidad por ser dicha práctica una herencia del periodo dictatorial (1964-1984). Las dictaduras amplían los casos de torturados no sólo en Brasil, sino también en otras partes del mundo cuando ignoran explícitamente los derechos civiles y llegan a afectar a diversas categorías de personas a manera de víctimas, especialmente clases sociales antes libres de ese tipo de violencia. No obstante, para algunos miembros de la sociedad brasileña resulta indistinto si viven en una democracia o en una dictadura, pues a ellos les toca la tortura antes, durante o después de las dictaduras: 


\section{Dimensiones histórico-sociológicas de la tortura en comisarías de Brasil: el caso Pernambuco}

son los pobres, los negros y los "no ciudadanos". Es verdad que durante la dictadura del 64 la tortura fue usada de forma asombrosamente más alta. Pero la Historia del mundo y, principalmente, de Brasil, descubre una tradición histórica de tortura contra determinados grupos. Su uso es cada vez menor, gracias a lo que se denominó "proceso civilizatorio", pero, aun así, sigue siendo mucho más amplio de lo que se supone.

Inicialmente, la tortura fue incentivada por la política de orden público, en la que los negros, vagos, mendigos, pícaros y maleantes eran el objetivo principal. Después empezaron a utilizarla como forma de investigación pre procesal. Hasta que finalmente fue prohibida, pero se continuó aplicando, por su facilidad, de manera informal hasta hoy con las mismas víctimas: los socialmente más vulnerables.

La tortura era y continúa siendo el método más sencillo de las fuerzas policiales para obtener su resultado final: la tranquilidad de las clases sociales que ejercen más influencia sobre su trabajo. Aunque repitan casi como un mantra que buscan la justicia, ellos buscan, antes de todo, el reconocimiento profesional ante sus pares y por parte de los extraños que ejercen influencia sobre sus superiores.

Desaparecidos sus soportes técnicos y legales, la tortura se hizo finalmente vulnerable a las críticas lógicas, morales y sociales ante las cuales había sido prácticamente inmune durante tanto tiempo. Sin embargo no desaparecieron las condiciones sociales que la tornaban muy útil: aumento de crímenes en proporción muy superior al crecimiento del aparato estatal para combatirlos; valor significativo atribuido a la confesión en el proceso penal; aceptación de la sociedad y de los operadores del sistema criminal en cuanto al uso de la tortura para los criminales (aunque sea disimulada); ventajas obtenidas por los policías cuando la utilizan como método de investigación, que son mayores a los perjuicios ocasionados por su uso (eventuales penas o castigos), y finalmente la precaria conciencia ciudadana de parte de población brasileña. 


\section{Dimensiones histórico-sociológicas de la tortura en comisarías de Brasil: el caso Pernambuco}

No podemos olvidarnos de algunas discusiones actuales (véase el capítulo 2) sobre la "legalidad" o "moralidad" del uso de la tortura. Sea cual fuera el posicionamiento frente a situaciones excepcionales de terrorismo o secuestros con rehenes, lo que buscamos analizar en este trabajo es otra cosa: la tortura "ordinaria". Aunque la tortura no deba ser aplicada ni en situaciones excepcionales, su cotidianidad y extensión sirve para demostrar cómo el tema puede ser tratado con más o menos tolerancia de acuerdo con el contexto y de cómo denominado "proceso civilizatorio" puede recibir golpes. Francia y EUA son "buenos ejemplos" de cómo sociedades desarrolladas, con democracia consolidada pueden retroceder en el tema de los derechos humanos dependiendo del contexto social y político.

Volviendo a la situación brasileña, es posible intentar comprender como legislaciones tan avanzadas pueden coexistir con prácticas tan retrasadas. Gracias a los niveles absurdos que alcanza la violencia urbana, la población llega a un estado de miedo en el cual es capaz de aceptar lo que otrora sería inaceptable: una policía que consigue ser tan criminal como los criminales. Es como si hubiera dos mundos: el de los ciudadanos y el de los criminales o criminales en potencia, pues parecer un criminal ya es suficiente para anular la ciudadanía. Para el mundo de los ciudadanos habrá el Estado Democrático de Derecho y para los "no ciudadanos" la barbarie. El único momento en que los ciudadanos se indignan con la barbarie es cuando ella aparece en la televisión o periódicos. En ese momento, la población, jueces, fiscales, abogados y policías se muestran indignados con actos que ellos saben que ocurren todos los días. Eso ayuda a que haya una gran impunidad. Entre los entrevistados es muy difícil encontrar a alguien que conozca policías punidos por la práctica de la tortura. Cuando miramos los documentos de puniciones de Asuntos Internos, son más frecuentes los casos de policías punidos por tráfico de drogas que por tortura. 


\section{Dimensiones histórico-sociológicas de la tortura en comisarías de Brasil: el caso Pernambuco}

Los entrevistados, aunque son muy pocos para establecer conclusiones definitivas, aportan esclarecimientos muy útiles sobre aspectos que en general son olvidados o desconocidos por los que tratan la cuestión:

Existencia de la tortura. No importa si el entrevistado tiene dos o veinte ocho años de policía. Todos, absolutamente todos, conocen comisarios y agentes que la practican. Un tercio de los comisarios y todos los agentes entrevistados confesaron que ya la han practicado. Casi la mitad de todos los entrevistados admitieron que pueden volver a practicarla. Repetimos, la muestra puede parecer pequeña, pero fue una muestra aleatoria, entre policías de diversos cargos, comisarías y edades.

Formación o preparación técnica. La Academia (formación policial) de la policial civil, al contrario de algunas Academias Militares, no entrena para la tortura, tampoco tortura a sus alumnos como forma de entrenamiento. El principal problema es que no consigue persuadir o disuadir a los que llegan con esa idea o son muy proclives a tal comportamiento. Al contrario, consigue introducir, aunque no intencionalmente o no directamente, la idea de que es necesaria en quién era contrario a ella. La Academia cuando no funciona bien, por falta de tiempo y también de una estructura más profesional para preparar a los alumnos para las actividades policiales, no alcanza su objetivo, que es preparar al policía para proteger indistintamente a los ciudadanos. Acaba entonces por convencer a muchos policías de la necesidad de torturar a los "no ciudadanos".

Si alguien hubiera conseguido salir de la Academia sin creer en la necesidad de la tortura, las prácticas son el penúltimo paso, durante el cual un veterano va a enseñar al "novinho" (nuevo policía) cómo se hace y qué importante es mantener el secreto, pues, de lo contrario, él será enviado para algún sitio desagradable, o muerto

- aunque no hemos encontrado evidencias de muertes por resistir o denunciar la tortura, percibimos ese tipo de miedo en algunos entrevistados - , por no ajustarse al "verdadero trabajo policial". Si después de la Academia y de las prácticas, alguien 


\section{Dimensiones histórico-sociológicas de la tortura en comisarías de Brasil: el caso Pernambuco}

mantiene sus convicciones contra la tortura, llegará el momento de ir a una comisaría. Ahí no se verá obligado a practicarla, puede trabajar en funciones burocráticas o en la "permanencia" (haciendo registros de acontecimientos - el trabajo menos respetado por los policías), pero jamás deberá impedir o denunciar a los compañeros que la practiquen, pues así conocerá la intolerancia en la policía. Queda muy claro que en la policía hay tolerancia con la tortura, con quien no hay tolerancia es con los denunciadores de la tortura.

Cultura corporativa. Al analizar los incentivos a favor o contra la práctica de la tortura percibimos que la ecuación es más favorable al torturador, pues concluye más casos, recibe más elogios, asciende más rápido y tiene pocas posibilidades de ser punido.

Productividad. La introducción de procedimientos administrativos basados en metas y objetivos a cumplir aumentó mucho la presión sobre los comisarios por obtener buenos resultados. Sin otros mecanismos de seguridad y control, la presión por resultados genera un aumento de la tortura.

Corrupción. Prácticamente todos los entrevistados establecieron una relación entre tortura y corrupción. Ilustraron cómo el uso de la tortura se puede transformar: de la tortura para investigar crímenes (interés colectivo) es muy fácil pasar a la tortura para sacar otros provechos ilícitos (interés individual).

Ausencia de políticas de recursos humanos. La mala formación técnica podría ser disminuida con una buena política de recursos humanos, pero eso es casi inexistente en la policía. No hay profesionales que den cuenta del perfil ideal de policía que la Organización necesita o incluso de cómo corregir problemas que afectan a los objetivos de la organización. Eso acaba por favorecer la práctica de la tortura, haciendo que el rechazo profesional sea más grande para quien está en contra de la tortura que para quien es favorable a la misma. Quien se posiciona como totalmente contrario a esta práctica puede ser visto por los colegas de trabajo como 


\section{Dimensiones histórico-sociológicas de la tortura en comisarías de Brasil: el caso Pernambuco}

un "profesional limitado", "poco flexible”, "débil”, "no apto para el trabajo”, etc. Y quien la practica sin ser corrupto tiende a ser visto como un profesional "dedicado", "esforzado", un "auténtico policía", en definitiva.

Para aclarar aún más, hay factores que favorecen la práctica de la tortura. Quien la practica lo hace influenciado por algunas de las situaciones siguientes, sin excluir otras posibilidades:

Deseo de INTEGRACIÓN más MACHISMO, pues quien se rehúsa a practicarla o denuncia a quien la practica corre el riesgo de ser visto cómo débil, inhábil, afeminado, poco profesional y poco fiable.

CONFIANZA en la eficiencia de la tortura y en el apoyo de la sociedad.

FALTA DE COMPROMISO MORAL de los policías y de la sociedad.

PRESIÓN de la sociedad, de la prensa y de los políticos, en los crímenes que repercuten en la opinión pública; de sus jefes, por la baja productividad; personal, por no desear parecer incompetente, además del DESCONOCIMIENTO de otras técnicas de investigación.

PRESIÓN más AUSENCIA DE MEDIOS humanos y materiales, ante un alto nivel de exigencia por el volumen de crímenes.

PRESIÓN más FACILIDAD (la tortura es más rápida que el empleo de técnicas de investigación legales).

CORRUPCIÓN (con la tortura se puede extorsionar al criminal o su familia) más FACILIDAD para obtener dinero mediante la amenaza de utilizar la tortura;

Además de la combinación entre los distintos tipos de "motivaciones" para torturar, hay un componente que es inherente a todas las combinaciones: la IMPUNIDAD. Queda claro que hay impunidad para quien practica la tortura. El control interno y externo son deficientes, situación que se evidencia claramente en todas las entrevistas. Todos los entrevistados conocían a un torturador, algunos admitieron que ya habían torturado, pero casi nadie conocía a policías castigados por 


\section{Dimensiones histórico-sociológicas de la tortura en comisarías de Brasil: el caso Pernambuco}

tortura. Como fue demostrado en los gráficos de punición de Asuntos Internos, es más fácil encontrar policías traficantes de drogas que torturadores.

La combinación de la PRESIÓN POR RESULTADOS (presión de sus jefes y/o por el deseo de ascenso y/o reconocimiento profesional), con la ACEPTACIÓN SOCIAL y la FACILIDAD DE OBTENER PRUEBAS a través de la tortura y de la IMPUNIDAD crea un ambiente "perfecto" para la permanencia de la tortura. Y los que la practican no esperan un reproche social; todo lo contrario, esperan aprobación social, aunque la relación entre la tortura y el éxito en su trabajo no sea muy explícita.

Como vimos, la tortura es común cuando se dan las condiciones más favorables: la concepción de la urgencia por defenderse de un enemigo; la deshumanización del enemigo; la culpabilización de la víctima; la aprobación implícita de la sociedad; la vigilancia mínima interna y externa; la falta de compromiso moral generalizada.

¿Dónde están las políticas públicas para disminuir la tortura? El Gobierno no se puede permitir el lujo de disminuir la presión sobre la fuerza pública para la obtención de resultados pues hay un gran número de crímenes y la gestión pública busca cada vez más productividad. Tampoco puede deshacerse de la facilidad con que se obtiene una confesión de un delito torturando a alguien. Lo único que puede hacer, y no hace, es disminuir la impunidad y mejorar la formación de los policías. ¿Por qué no lo hace? Quizá el coste político resulta muy alto en una sociedad con valores morales endebles y no conviene ser visto como un "defensor de criminales".

¿Cuál es el aspecto más relevante de la tesis? Creemos que la relevancia de los discursos de los policías que admiten la tortura. Primero, porque no conocemos otros trabajos académicos que traten la tortura en la institución policial de Brasil en la actualidad, basados en las posiciones del torturador. Segundo, porque la policía es una organización demasiado cerrada que siempre se negó a dar información a los 


\section{Dimensiones histórico-sociológicas de la tortura en comisarías de Brasil: el caso Pernambuco}

investigadores. Tercero, que ahora tenemos las voces de algunos que, hasta donde conocemos, siempre negaron sistemáticamente la práctica de la tortura, reconociendo la existencia de ella y además explicitando su funcionalidad. Cuarto, porque la recogida de indicios de este género permite transformar la indiferencia pública en escándalo y a su vez, el escándalo en políticas públicas más eficaces que puedan ayudar a disminuir la práctica de la tortura en Brasil y América Latina.

Más que llamar la atención sobre la barbarie y su perpetuación, deseamos contribuir también a presentar sugerencias para combatir de la tortura en las comisarías. Buscamos extraer tales sugerencias de los discursos de policías entrevistados y de los trabajos y documentos que tratan del combate a la tortura.

- Instalar cámaras en las comisarías - entradas, atendimiento y cárcel. Las entrevistas revelaron uno de los grandes temores de los policías: las cámaras de los teléfonos móviles. Además ello puede ser una herramienta fundamental para las investigaciones de la tortura, dando más fuerza al relato de la víctima. Eso también contribuye a disminuir la corrupción, malos tratos en las comisarías y muchas otras irregularidades practicadas en ellas, pues Asuntos Internos pasa a tener un excelente medio de prueba.

- Crear una unidad específica de combate a la tortura. Como vimos en todo el cuerpo de la tesis, este es un problema que está presente en toda la historia de la policía, en verdad, de la humanidad, pero en el caso de la policía se presenta, junto con la corrupción, como uno de los más graves problemas de ese tipo de organización. El problema es que hay presión para solucionar muchos crímenes de otra naturaleza y, al mismo tiempo, hay mucha presión de los colegas de trabajo para no investigar a colegas. El resultado es que el descubrimiento de este tipo 


\section{Dimensiones histórico-sociológicas de la tortura en comisarías de Brasil: el caso Pernambuco}

de delito casi nunca es prioritario. Una posible solución sería crear una unidad específica para esclarecerlo exclusivamente. Ello tendría dos efectos: preventivo, pues los policías percibirían que ahora sería más peligroso practicar la tortura; represivo, pues sin la competencia con otros crímenes, la investigación de la tortura tendría que aumentar considerablemente, junto con la calidad de las investigaciones.

- Instituir la carrera de Asuntos Internos. Si no fuera bastante la bibliografía que demuestra el corporativismo de las policías, y de otros profesionales también, en castigar a sus propios colegas, las entrevistas demostraron que hay mucha más presión contra quien investiga a un colega de trabajo que contra una persona que practica la tortura. Un policía que está en AI hoy puede volver mañana al cuerpo de policía y estar bajo el mando de alguien que él mismo investigó. Eso crea una situación de riesgo muy grande para un policía que trabaja en AI. Además, un trabajo que trata de investigar a policías puede ser más arriesgado que investigar a criminales, pues los policías saben cómo funciona la investigación y tienen mucho más que perder que los criminales. De ahí que se hace necesaria una profesionalización y separación del cuerpo policial.

- La Academia de Policía I - debe tratar el tema de la tortura, de forma transversal, en todas las disciplinas. Cuando se discute la tortura solamente en las clases de derechos humanos, en una cultura que considera a los derechos humanos "derechos de criminales", el tema no es tratado con el cuidado necesario. Casi todos los entrevistados dijeron que la Academia de Policía no trata con la debida atención el tema. 


\section{Dimensiones histórico-sociológicas de la tortura en comisarías de Brasil: el caso Pernambuco}

- La Academia de Policía II - debe mejorar la enseñanza de la investigación policial. Todos los entrevistados dijeron que no aprendieron a investigar en la Academia. Es imposible acabar con la tortura sin sustituirla por otro método.

- Cartel o folder de Asuntos Internos en los sitios estratégicos donde se hallan los usuarios del servicio, encarcelados o sospechosos. El bajo número de denuncias en $\mathrm{AI}$ puede ser un indicativo del desconocimiento de la unidad.

- Publicidad y entrenamiento. Ha quedado claro que estamos ante un problema histórico y sociocultural. Por eso es necesario trabajar con todos los involucrados, incluidos fiscales, médicos forenses, abogados, jueces y población en general.

- Debe establecer en procedimiento modelos para entrevistas e interrogatorios, y grabación con procedimientos modelo. Eso aumentaría la seguridad de todos, policías y sospechosos, pues, además del momento de la llegada del sospechoso, el interrogatorio es el segundo momento más peligroso para el mismo.

Estas sugerencias están basadas en fragmentos de los discursos de policías entrevistados y tratan de tres tipos de acciones: políticas de recursos humanos; medidas contra la impunidad; y, medidas de seguridad. Juntas, creemos que pueden significar un paso importante para acabar con la cultura de la tortura $y$, principalmente, del tratamiento desigual que la población recibe de los policías. Quizá pueda representar un cambio más significativo incluso que algunos Tratados Internacionales firmados por Brasil. 


\section{Dimensiones histórico-sociológicas de la tortura en comisarías de Brasil: el caso Pernambuco}

\section{BIBLIOGRAFÍA}

ADERALDO, Guilhermo. "A violência em cartaz”. In: Revista Sociologia Ciência. Ano II, número 14, 2010.

ADORNO, Sérgio. "Crime, justiça penal e desigualdade jurídica: as mortes que se contam no tribunal do júri”. In: Revista USP, 1994. (n. 21, março-maio: p. 132-51). - "Consolidação democrática e políticas de segurança pública no Brasil: rupturas e continuidades". In: ZAVERUCHA, Jorge (Org.). Democracia e instituições políticas brasileiras no final do século XX. Recife: Bagaço, 1998.

ALBUQUERQUE, Carlos L. e MACHADO, Eduardo P. "Currículo e contracurrículo na reforma do ensino policial militar brasileiro". In: unidade - Revista de Assuntos Técnicos da Polícia Militar - Ano XIX - Porto Alegre, RS, n. ${ }^{\circ}$ 47, julho/setembro de 2001.

ALMEIDA, Alberto Carlos. "A cabeça do brasileiro”. Rio de Janeiro: Record, 2007.

ALVES, Márcio Moreira. "Torturas e torturados". Rio de Janeiro: Idade Nova, 1987.

AMNISTÍA INTERNACIONAL. Revista Bimestral para los países de habla hispana. N. 45, octubre-noviembre de 2000.

. Tortura e maus-tratos no Brasil: desumanização e impunidade no sitema de justiça criminal. Brasil: Nova Prova, 2001.

. España: sal en la herida - la impunidad efectiva de agentes de policía en casos de tortura y otros malos tratos. Madrid: Amnesty International Publications, 2007. 


\section{Dimensiones histórico-sociológicas de la tortura en comisarías de Brasil: el caso Pernambuco}

—. "Brazil: commentary on Brazil's first report to the UM Committee Against Torture”. Relatório AMR. 19/016/2001, 2001a. . "Stopping the torture trade”. Londres: A I Publications, $2001 \mathrm{~b}$.

ARAÚJO, Luis César G. de \& GARCIA, Adriana Amadeu. "Gestão de pessoas: estratégias e integração organizacional”. 2 ed. São Paulo: Atlas, 2009.

ARNS, Paulo Evaristo (Prefácio). "Brasil: nunca mais: um relato para a história”. Petrópolis: Vozes, 1996.

BARCELLOS, Caco. “Rota 66”. 23. a ed. São Paulo: Globo, 1994.

BARDIN, Laurence. “Análise de Conteúdo”. Trad. Luís A. Reto, Augusto Pinheiro. São Paulo: Ediçoes 70, 2011..

BARROS, Marcelo. "Políticas Públicas de Segurança no Brasil: mito ou realidade?" In: RATTON, José Luiz; BARROS, Marcelo. Polícia, Democracia e Sociedade. Rio de Janeiro: Lumen Juris, 2007.

BATISTA, Nilo. "Punidos e mal pagos: violência, justiça, segurança pública e direitos humanos no Brasil de hoje”. Rio de Janeiro: Revan, 1990.

BAYLEY, David H. "Padrões de policiamento". Trad. Renê A. Belmonte. - São Paulo: Editora da Universidade de São Paulo, 2001. (Série Polícia e Sociedade; n. 1). Universidade de São Paulo, 2001.

BAYLEY, David H. e SKOLNICK, Jerome H. "Nova polícia: inovações nas polícias de seis cidades norte-americanas”. Trad. Geraldo G. de Souza. - São Paulo: Editora da Universidade de São Paulo, 2001. (Série Polícia e Sociedade; n. 2). BECCARIA, Cesare. De los delitos y de las penas. Trad. Francisco Tomas Y Valiente. Madrid: Aguilar, 1982.

BECKER, Gary S. "Crime and punishment: an economic approach". Journal of political economy. v. 76, n. 01. 1968. p.169-217. 


\section{Dimensiones histórico-sociológicas de la tortura en comisarías de Brasil: el caso Pernambuco}

BELLO, Juliana. "Crime de tortura”. Monografia de conclusão de curso. Programa de Graduação em Direito, Faculdade de Direito de São Bernardo do Campo. São Paulo, 2002.

BERGER, Peter \& LUCKMANN, Thomas. La construcción social de la realidad. Buenos Aires: Amorrortu, 1968.

BITTNER, Egon. “Aspectos do trabalho policial”. Trad. Ana L. A. Pinheiro. - São Paulo: Editora da Universidade de São Paulo, 2003. (Série Polícia e Sociedade; n.8 ). BOURDIER, Pierre. ¿Qué significa hablar? Economía de los intercambios lingüísticos. Madrid: Akal, 1985.

BOXER, Charles R. "A idade do ouro do Brasil: dores de crescimento de uma sociedade colonial”. Trad. Nair de Lacerda. Rio de Janeiro: Nova Fronteira, 2000.

BRAGA, Raquel Willadino. "Arquiteturas Organizacionais, Modelos de Gestão e Indicadores de Eficiência das Corregedorias e Ouvidorias de Polícia”. Brasil: Ministério da Justiça/Secretaria Nacional de Segurança Pública - SENASP, Relatório Final -

BRANDÃO, Carlos Rodrigues. "O que é educação”. 40. " reimpressão, São Paulo: Brasiliense, 2001.

BRASIL. Secretaria Especial dos Direitos Humanos. "Direito à memória e à verdade: Comissão Especial sobre Mortos e Desaparecidos Políticos”. - 2. ed. Recife: Governo do Estado, 2008.

BRODEUR, Jean-Paul. "Como reconhecer um bom policiamento". Trad. Ana Luiza A. Pinheiro. - São Paulo: Editora da Universidade de São Paulo, 2002. (Série Polícia e Sociedade; n. 4).

BRONFENBRENNER, U. "A ecologia do desenvolvimento humano: experimentos naturais e planejados”. Porto Alegre: Artes Médicas, 1996. (Originalmente publicado em 1979). 


\section{Dimensiones histórico-sociológicas de la tortura en comisarías de Brasil: el caso Pernambuco}

BUENO, Eduardo. "Capitães do Brasil: a saga dos primeiros colonizadores”. Rio de Janeiro: Objetiva, 1999. (Coleção Terra Brasilis; 3).

"A coroa, a cruz e a espada". Rio de Janeiro: Objetiva, 2006. (Coleção

Terra Brasilis; 4).

BURIHAN, Eduardo Arantes. “A tortura como crime próprio”. São Paulo: Juarez de Oliveira, 2008.

CABEZAS, Jorge. Infiltrados: de ETA a AL QAEDA. Barcelona: Planeta Actual, 2004.

CALDEIRA, Tereza. "Cidade de Muros: crime, segregação e cidadania em São Paulo”. São Paulo: Edusp, 2000.

CANCELLI, Elizabeth. "O mundo da violência: a polícia da era Vargas". 2. ed. Brasília: Universidade de Brasília, 1994.

. “A cultura do crime e da lei: 1889-1930”. Brasília: Universidade de Brasília, 2001.

CANEN, Ana. e MOREIRA, C4 F. B. “Ênfases e omissões no currículo". Campinas, SP: Papirus, 2001.

CANO, Inácio \& SANTOS, Nilton. "Violência letal, renda e desigualdade social no Brasil”. Rio de Janeiro: 7Letras, 2001.

CAPARRÓS, Nicolás. Efectos de la tortura sobre la personalidad. In: COROMINAS, J. y FARRÉ, J.M. (editores). Contra la tortura. Barcelona: Editorial Fontanella, 1978.

CAPELATO, Maria Helena. “O Brasil Republicano”. Rio de Janeiro: Civilização Brasileira, 2003.

CARDIA, Nancy. "Direitos Humanos: ausência de cidadania e 'exclusão mora'l". São Paulo: Arquidiocese de São Paulo/Comissão Justiça e Paz, 1995. 


\section{Dimensiones histórico-sociológicas de la tortura en comisarías de Brasil: el caso Pernambuco}

CARDOSO, Cármen; CUNHA, Francisco Carneiro da. "Compreendendo a organização: uma abordagem psicossociológica”. Recife: Instituto de Tecnologia em Gestão, 2001. (Cadernos INTG. Fundamentos teóricos, 1).

CARDOSO, Ciro F. Santana. "O trabalho na Colônia”. In: LINHARES, Maria Yedda L. (Coord.); CARDOSO, Ciro F. Santana... [et al.]. "História Geral do Brasil: da colonização portuguesa à modernização autoritária”. Rio de Janeiro: Campus, 1990.

. "A crise do colonialismo luso na América Portuguesa". In: LINHARES, Maria Yedda L. (Coord.); CARDOSO, Ciro F. Santana... [et al.]. "História Geral do Brasil: da colonização portuguesa à modernização autoritária”. Rio de Janeiro: Campus, 1990.

CAROS AMIGOS. “A Ditadura Militar no Brasil”. In: Fascículo 8 - Governo Médici: Terror total. São Paulo: Caros Amigos, 2007. - (Coleções Caros Amigos). CARTA CAPITAL. "Mulheres na Segurança Pública”. Por: Wânia Pasinato. 10 de abril de 2013.

CARVALHO, José Murilo de. "Cidadania do Brasil: o longo caminho". Rio de Janeiro: Civilização Brasileira, 2001.

CASTELL, Manuel. “A sociedade em rede”. São Paulo: Paz e Terra, 1999.

CAVA, Ralph Della. “Torture in Brasil”. Commonwelth, v. 24, p. 135-141, abr. 1970.

CEDEC. “Mapa de risco da violência”. Cidade de São Paulo. São Paulo, 1996.

CHARLOT, Bernard. "A mistificação pedagógica - realidades sociais e iprocessos ideológicos na teoria da educação”. 2. "ed. Rio de Janeiro: Guanabara, 1986.

CHIZZOTTI, Antonio. "Pesquisa qualitativa em ciências humanas e sociais". Petrópolis, RJ: Vozes, 2006. 


\section{Dimensiones histórico-sociológicas de la tortura en comisarías de Brasil: el caso Pernambuco}

CNBB, Comissão Pastoral. "Relatório sobre a Tortura: uma experiência de monitoramento dos locais de detenção para prevenção da tortura”. São Paulo: 2010.

COELHO, Edmundo C. "A criminalidade urbana violenta”. Rio de Janeiro: Revista de Ciências Sociais, vol. 31, n.2, 1988.

COHEN, Lawrence \& FELSON, Marcus. "Social change and crime rate trends: a routine approach”. In: “American Sociological Review”, 44, 1979.

COIMBRA, Cecilia. "Tortura no Brasil como herança cultural dos períodos autoritários". In: "Anais do Seminários Nacional - A eficácia da lei de tortura". Brasília, Dez/2000.

COIMBRA, Mario. “Tratamento do Injusto Penal da Tortura”. São Paulo: Revista dos Tribunais, 2002.

"Concursos Nacionais de Pesquisas Aplicadas em Justiça Criminal e Segurança Pública”, SENASP, Abril/2006.

DA MATTA, Roberto. "As raízes da violência no Brasil: reflexões de um antropólogo social”. In: Maria Célia Paoli et al., "A violência brasileira”. São Paulo: Brasiliense, 1982.

DA SILVA (a), Francisco C. Teixeira. "Conquista e Colonização da América Portuguesa (o Brasil Colônia - 1500)". In: LINHARES, Maria Yedda L. (Coord.); CARDOSO, Ciro Flamarion Santana... [et al.]. "História Geral do Brasil: da colonização portuguesa à modernização autoritária”. Rio de Janeiro: Campus, 1990.

DA SILVA (b), Tomaz T. "Documentos de identidade: uma introdução às teorias do currículo”. Belo Horizonte: Autêntica, 1999.

DEAL, Terrence E. \& KENNEDY, Allan A. “Corporate Culture”. Perseus: 2000.

DEL PRIORE, Mary; VENÂNCIO, Renato. "O livro de ouro da História do Brasil”. Rio de Janeiro: Ediouro, 2001. 


\section{Dimensiones histórico-sociológicas de la tortura en comisarías de Brasil: el caso Pernambuco}

DERSHOWITZ, Alan M. "Why Terrorism Work: Understanding the Threat". Responding the Challenge. Yale University Press, New Haven, 2002.

DIAS, Reinaldo. “Cultura organizacional”. Campinas, SP: Editora Alínea, 2003. Coleçao Administraçao \& Sociedade (Org. Reinaldo Dias).

DIEZ, Jean-Michel. Investigación y lucha contra la tortura: exploraciones de un nuevo paradigma de los derechos humanos. In: Anais do Seminário Nacional A Eficácia da Lei de Tortura. Brasília, Dez/2000.

FAUSTO, Boris. “História Concisa do Brasil”. São Paulo: Edusp, 2002.

FEITLOWITZ, Marguerite. "A léxicon of terror: Argentina and the legacies of torture”. Nova York: Oxford University Press, 1998.

FERREIRA, Helder R. Sant'Ana. “Classes populares, polícia e punição”. Dissertaçao de Mestrado - Sociologia. São Paulo: USP, 2002.

FICO, Carlos. "Como eles agiam - Os subterrâneos da Ditadura Militar: espionagem e polícia política”. Rio de Janeiro: Record, 2001.

FOLHA DE SÃO PAULO. Ano 88, n. 29.008, Quarta-feira, 3 de setembro de 2008 Cotidiano, C3.

FON, Antonio Carlos. “A tortura: a história da repressão política no Brasil”. São Paulo: Global, 1986.

FRAGOSO. João Luís. "A Política no Império e no início da República Velha: dos Barões aos Coronéis”. In: LINHARES, Maria Yedda L. (Coord.); CARDOSO, Ciro Flamarion Santana... [et al.]. História Geral do Brasil: da colonização portuguesa à modernização autoritária. Rio de Janeiro: Campus, 1990.

FRANCO, Maria S. de C. Homens livres na ordem escravocrata. São Paulo: Kairos, 1983.

FREITAS, Maria Ester de. "Cultura Organizacional: evolução e crítica”. São Paulo: Cengage Learning, 2010. -- (Coleção debates em administração / coord. Isabela F. G. de Vasconcelos, Flávio C. de Vasconcelos). 


\section{Dimensiones histórico-sociológicas de la tortura en comisarías de Brasil: el caso Pernambuco}

GARRETÓN, Roberto. Qué es ser “torturador”? In: VERDUGO, Patricia (Org.). De la tortura no se habla: Agüero versus Meneses. Santiago de Chile: Catalonia, 2004.

GASCÓN, Ricardo. Privación de Libertad y Derechos Humanos: la tortura y otras formas de violencia institucional. OSPDH, Observatorio del Sistema Penal y los Derechos Humanos de la Universidad de Barcelona (coord.). Barcelona: Icaria editorial, 2008.

GIBSON, Janice; HARITOS-FATOUROS, Mika. "The education of a torturer". Psychology Today, p. 30-58, nov. 1986.

. "The oficial torturer: a learning model for obedience to na authority of violence”. Journal of Applied Social Psychology, 18: p. 1107-1120, 1988.

GILL, Rosalind. "Análise de discurso". In: BAUER, Martin W. \& GASKELL, George. Pesquisa qualitativa com texto: imagem e som: um manual prático. Trad. Pedrinho A. Guareschi. Petrópolis, RJ: Vozes, 2002.

GOIS, Anselmo. "Soldados cantam bordão curioso durante Cooper". Jornal do Comércio, Ano LXXXIII, n. ${ }^{\circ}$ 273, p.2, 30/09/02.

GOLDSTEIN, Herman. "Policiando uma sociedade livre”. Trad. Maria Cristina P. da Cunha Marques. - São Paulo: Editora da Universidade de São Paulo, 2003. (Série Polícia e Sociedade; n. 9).

GOMES, Laurentino. "1808: como uma rainha louca, um príncipe medroso e uma corte corrupta enganaram Napoleão e mudaram a história de Portugal e do Brasil”. São Paulo: Planeta do Brasil, 2007.

GOMES (b), Angela de Castro. "A política brasileira em busca da modernidade: na fronteira entre o público e o privado”. In: Fernando A. Novais (Coord.); Lilia Moritz Schwarcz (Org.). São Paulo: Companhia das Letras, 1998. 


\section{Dimensiones histórico-sociológicas de la tortura en comisarías de Brasil: el caso Pernambuco}

GREENE, Jack R. “Administraçao do trabalho policial”. Trad. Ana Luiza A. Pinheiro. - São Paulo: Editora da Universidade de São Paulo, 2002. (Série Polícia e Sociedade; n. 5).

GUEIROS, José A. “O último tenente”. 3. ª ed. Rio de Janeiro: Record, 1996.

GUERRA, Alba, G. "O crime, realidade e desafio: abordagem psicodinâmica do homicídio”. Recife: PE: A. G. Guerra, 1990.

GUIMARÃES, Alberto P. "As classes perigosas: banditismo urbano e rural”. Rio de Janeiro: Edições Graal, 1981.

GUTIÉRREZ, Francisco. “Educação como práxis política”. São Paulo: Summus, 1998.

HARITOS-FATOUROS, Mika. "The psychological origins of institutionalized torture”. Nova York: Routledge, 2002.

HARITOS-FATOUROS, Mika; HUGGINS, Martha K.; BOZATZIS, Nicos. "Identity characteristics as expressed by policemen torturers and killers who served under the Brazilian dictatorship”. Paper presented at the Political Psychology Annual Conference. Seatle, Washington, 2000.

HOBSBAWM, Eric J. "Bandidos". 2. a ed. Rio de Janeiro: Forense Universitária, 1976.

HOLANDA, Sergio Buarque de. "Raízes do Brasil”. 26.ed. - São Paulo: Companhia das Letras, 1995.

HOLLOWAY, Thomas H. "Polícia no Rio de Janeiro: repressão e resistência numa cidade do século XIX”. Trad. Francisco de Castro Azevedo. Rio de Janeiro: Editora Fundação Getúlio Vargas, 1997.

HOUAISS. "Dicionário Eletrônico da Língua Portuguesa”. Versao 1.0. Editora Objetiva, Dezembro de 2001.

HUGGINS, Martha K. "Legacies of authoritarianism: Brazilian torturers and murderers reformulation of memory”. Latin American Perspectives, v.30, 2000. 


\section{Dimensiones histórico-sociológicas de la tortura en comisarías de Brasil: el caso Pernambuco}

HUGGINS, Martha K.; HARITOS-FATOUROS, Mika; ZIMBARBO, Philip G. "Operários da Violência: policiais torturadores e assassinos reconstroem as atrocidades brasileiras”. Brasília: UnB, 2006.

JOBARD, Fabien. "Bavures policières? La force publique et ses usages”. Paris: La Découverte, 2002.

KANT DE LIMA, Roberto. "A polícia da Cidade do Rio de Janeiro: seus dilemas e paradoxos”. Rio de Janeiro: Biblioteca da Polícia Militar, 1994.

- “Cultura jurídica e práticas policiais: a tradição inquisitorial”. Revista

Brasileira de Ciências Sociais. São Paulo: ANPOCS, ano 4, n.10.

KOSHIBA, Luiz \& PEREIRA, Denise Manzi Frayse. "História do Brasil”. São Paulo: Atual, 1979.

KOK, Glória. "Descalços, violentos e famintos: entre cascavéis, onças e flechas inimigas, os bandeirantes ainda perigavam morrer de fome nos sertões". In: Bandeirantes: o outro lado do mito. Revista de História, Biblioteca Nacional. Ano 3 - no. 34 - julho de 2008.

LANGBEIN, John H.. "Torture and the Law of Proof: Europe and England in the Ancient Regime”. Chicago: The University of Chicago Press, 1976.

LEMGRUBER, Julita; MUSUMECI, Leonarda; CANO, Ignacio. "Quem vigia os vigias?”. Rio de Janeiro: Record, 2003.

LEMOS-NELSON, Ana T. "Criminalidade policial, cidadania e estado de direito". In: Cadernos CEAS, n. ${ }^{\circ}$ 197, Salvador, Janeiro/Fevereiro 2002.

LIFTON, R. J. "The nazi doctors: medical killing and the psychology of genocide". Nueva Yorque: Basic Books, 1986.

LIMA, Mauro Faria. "Crimes de tortura: comentários à lei 9.455, de 07 de abril de 1997”. Brasília: Brasília Jurídica, 1997. 


\section{Dimensiones histórico-sociológicas de la tortura en comisarías de Brasil: el caso Pernambuco}

LIMA, Renato Sérgio de \& RATTON, José Luiz (Orgs.). "As ciências sociais e os pioneiros nos estudos sobre crime, violência e direitos humanos no Brasil”. Fórum Brasileiro de Segurança Pública; Urbania; ANPOCS, 2011.

LIZANDRA, Grima Vicente. Los delitos de tortura y de tratos degradantes por funcionários públicos. Valencia: Tirant lo blanch, 1998.

LUDWIG, Antonio C. W. “Democracia e ensino militar”. São Paulo: Cortez, 1998. MARIZ MAIA, Luciano. "Mecanismos de punição e prevenção da tortura”. In: Anais do Seminário Nacional - “A Eficácia da Lei de Tortura”. Brasília, Dez/2000. MÉNDEZ, Juan E. O’DONNELL, Guillermo. e PINHEIRO, Paulo S. (Orgs.). "Democracia, violência e injustiça: o Não-Estado de direito na América Latina". São Paulo: Paz e Terra, 2000.

MENDONÇA, Sonia Regina de. "Estado e Sociedade: a consolidação da república oligárquica”. In: LINHARES, Maria Yedda L. (Coord.); CARDOSO, Ciro Flamarion Santana... [et al.]. "História Geral do Brasil: da colonização portuguesa à modernização autoritária”. Rio de Janeiro: Campus, 1990.

MILGRAN, S. “Obedience to authority”. Nova York: Harper \& Row, 1974.

MINGARDI, Guaraci. "Tiras, gansos e trutas: cotidiano e reforma na Polícia Civil”. São Paulo: Ed. Página Aberta, 1992.

MISSE, Michel. "Cinco teses equivocadas sobre a criminalidade urbana no Brasil: uma abordagem crítica, acompanhada de sugestões para uma agenda de pesquisas”. Rio de Janeiro: Iuperj, 1995.- Série Estudos: Violência e participação política no Rio de Janeiro - No. 91.

MOLLFUllEDA, Santiago. Juan Pablo Forner: discurso sobre la tortura. Barcelona, Editorial Crítica, 1990.

MONET, Jean-Claude. "Polícias e Sociedades na Europa”. Trad. Mary Amazonas L. de Barros. São Paulo: Edusp, 2001. - (Série Polícia e Sociedade; n. 3). 


\section{Dimensiones histórico-sociológicas de la tortura en comisarías de Brasil: el caso Pernambuco}

MONJARDET, Dominique. "O que faz a polícia: sociologia da força pública”. Trad. Mary Amazonas L de Barros. - São Paulo: Editora da Universidade de São Paulo, 2003. (Série Polícia e Sociedade; n. 3).

MONTEIRO, Hamilton de Mattos. "Da Independência à Vitória da Ordem”. In: LINHARES, Maria Yedda L. (Coord.); CARDOSO, Ciro Flamarion Santana... [et al.]. "História Geral do Brasil: da colonização portuguesa à modernização autoritária”. Rio de Janeiro: Campus, 1990.

MORAIS, Paulo. "Segurança pública e as organizações policiais". Recife: Bagaço, 2008.

MUNIZ, Jacqueline. "Sobre polícia e politicagem". Revista Carta Capital, 15 de agosto de 2007, Ano XIII, n. 457.

NAFFAH NETO, Alfredo. "Poder, vida e morte na situação de tortura: esboço de uma fenomenologia do terror”. São Paulo: Brasiliense, 1983.

NUNES, Jorge Fischer. “O riso dos torturados”. Porto Alegre, Proletra, 1982.

OLIVEIRA, Luciano. "Polícia e classes populares". Caderno de Estudos Sociais, v. 1, n.1, Recife, 1985.

"Do nunca mais ao eterno retorno: uma reflexão sobre a tortura”. São

Paulo: Brasiliense, 1994.

OLIVEIRA (b), Cristiano A. de. "Criminalidade e o tamanho das cidades brasileiras: um enfoque da economia do crime”. Anais do XXXIII Encontro Nacional de Economia - UFRGS - 2005.

OLIVEN, Ruben George. "Violência e Cultura no Brasil". 4a. Ed. Rio de Janeiro: Vozes, 1989.

PAIXÃO, Antonio Luiz. "O problema da polícia”. Rio de Janeiro: Iuperj, 1995.Série Estudos: Violência e participação política no Rio de Janeiro - No. 91. 


\section{Dimensiones histórico-sociológicas de la tortura en comisarías de Brasil: el caso Pernambuco}

- "Crime, controle social e consolidação da democracia: as metáforas da cidadania”. IN: Fábio Reis \& Guillermo O’Donnell (Orgs.). “A democracia no Brasil: dilemas e perspectivas”. São Paulo: Vértice, 1988.

“Crimes, vítimas e policiais”. Revista de Sociologia da USP, vol. 9, n.1, maio de 1997.

PANDOLFI, Dulce C. CARVAlHO, José M. de. CARNEIRO, Leandro P. GRYNSZPAN, Mario. “Cidadania, justiça e violência”. Rio de Janeiro: Fundação Getúlio Vargas, 1999.

PASSETTI, Edson. "Cartografia de violências”. In: Revista Serviço Social \& Sociedade - Violência - Ano XXIII, n. 70, julho de 2002 - São Paulo: Cortez.

PASSOS, Adalberto H. "Polícia e tortura: uma análise dos crimes de tortura cometidos pelos integrantes da Secretaria de Defesa Social de Pernambuco nos anos de 2008 e 2009”. Monografia para conclusão de Especialização em Políticas Públicas de Segurança. Recife: FACIPE, 2010.

PELLONI, Fernando M. Machado. Argumentos contra la tortura y los tratos crueles, inhumanos y degradantes. Estudios Constitucionales, Año 8, No 1, 2010.

PERALVA, Angelina. "Violência e democracia: o paradoxo brasileiro”. São Paulo: Paz e Terra, 2000.

PETERS, Edward. La tortura. Madrid: Alianza Editorial, 1987.

PIERANGELI, José Henrique. “Códigos Penais do Brasil: evolução histórica”. São Paulo: Revista dos Tribunais, 2001.

PINHEIRO, Paulo Sergio. "Violencia, crime e sistemas policiais em países de novas democracias". Tempo Social. Revista de Sociologia da USP. Departamento de Sociologia, Faculdade de Filosofia, Letras e Ciências Humanas, USP, 9 (1): maio. "O passado não está morto nem é passado ainda". In: PINHEIRO et al. “Continuidade autoritária e construção da democracia. Relatório final”. São Paulo: Núcleo de Estudos da Violência, NEV/USP, 1999. 


\section{Dimensiones histórico-sociológicas de la tortura en comisarías de Brasil: el caso Pernambuco}

_. "Tortura, intolerância, direitos humanos". Rio Grande do Sul, Terceiro Seminário Internacional Polícia e Sociedade Democrática, 2002.

PINTO, María \& GALVÉZ, Carmen. Análisis documental del contenido. Madrid: Síntesis, 1996.

PIOVESAN, Flavia. "Direitos Humanos e o Direito Constitucional Internacional". São Paulo: Max Limonad, 2002.

PRADO JUNIOR, Caio. “Formação do Brasil contemporâneo”. Colônia. $7^{\mathrm{a}}$. Edição. São Paulo: Brasiliense, 1963.

QUEL LOPÉZ, J. y CASADEVANTE, C. La lucha contra la tortura: aspectos del derecho internacional y del derecho interno español. Bilbao: HEEE/IVAP, 1991.

QUINTEIRO, Maria Esther Martínez. Crisis de la modernidad y derechos humanos. In: La crisis en la História. Salamanca: Ediciones Universidad, 1995.

RAMOS, Silvia \& PAIVA, Anabela. "Mídia e violência: novas tendências na cobertura de criminalidade e segurança no Brasil”. Rio de Janeiro: IUPERJ, 2007.

RATTON, José Luiz; BARROS, Marcelo (Orgs.). "Polícia, Democracia e Sociedade. Rio de Janeiro: Lumen Juris, 2007.

REINALDI, Víctor. El delito de tortura. Buenos Aires: Ediciones Depalma, 1986.

REINER, Robert. "A política da polícia”. Trad. Jacy Cardia Ghirotti e Maria Cristina P. da C. Marques. - São Paulo: Editora da Universidade de São Paulo, 2004. REVISTA VEJA. "Enfim, um herói do lado certo: recordista de público, Tropa de Elite 2 consagra o tenente-coronel Nascimento, vivido por Wagner Moura, como o exemplo do policial honrado com que todos os brasileiros gostariam de contar". Reportagem de Bruno Meier e Jerônimo Teixeira. Editora ABRIL, edição 2190 ano43 - n. 45, 10 de novembro de 2010.

RIBEIRO, Darcy. "O povo brasileiro: a formação e o sentido do Brasil”. São Paulo: Companhia das Letras, 1995. 


\section{Dimensiones histórico-sociológicas de la tortura en comisarías de Brasil: el caso Pernambuco}

RIVERA, Carmen Cecilia. Descripción de cultura organizacional. Dialogos de la comunicación. Teórico de la Federación Latinoamericana de Faculdades de Comunicación Social. Cali, Colombia, no 39, pp. 36-41, jun. 1994.

ROBERTSON, Geoffrey. Crímenes contra la humanidad: la lucha por una justicia global. Trad. C4 Resines. Madrid: Siglo XXI, 2008.

ROBLES, Diego Torrente. La sociedad policial: poder, trabajo y cultura en una organización local. Madrid: Centro de Investigaciones Sociológicas/Universidad de Barcelona, 1997.

RODLEY, Nigel. "Relatório sobre a tortura no Brasil produzido pelo relator especial sobre a tortura da Comissão de direitos humanos da ONU”, 2001.

RODRIGUÉZ-MESA, María José. Tortura y otros delitos contra la integridad moral cometidos por funcionarios públicos. Granada: Editora Comares, 2000.

ROLIM, Marcos. "Tortura no Brasil como Herança Cultural dos Períodos Autoritários. In: Anais do Seminário Nacional "A eficácia da lei de tortura" Brasília, dezembro de 2000.

SANDEL, Michael J. “Justiça: o que é fazer a coisa certa”. Trad. Heloísa Matias e Maria Alice Máximo. Rio de Janeiro: Civilizaçao Brasileira, 2011.

SCHEIN, Edgar H. "Organizational Culture and Leadership”. 2. Ed. San Francisco: Jossey-Bass, 1992. . “Guia de sobrevivência da cultura corporativa”. Rio de Janeiro: José Olympio, 2001.

SCHREIBER, Simone. "Mecanismos de punição e prevenção da tortura". Anais do Seminário Nacional A Eficácia da Lei de Tortura. Brasília, Dez/2000.

SCHWARCZ, Lilia Moritz. "Nem preto nem branco, muito pelo contrário: cor e raça na intimidade”. In: Fernando A. Novais (Coord.); Lilia Moritz Schwarcz (Org.). São Paulo: Companhia das Letras, 1998. 


\section{Dimensiones histórico-sociológicas de la tortura en comisarías de Brasil: el caso Pernambuco}

SENNETT, Richard. "Autoridade”. Trad. Vera Ribeiro. Rio de Janeiro: Record, 2001.

SEVOCÊENKO, Nicolau. "Da escravidão à liberdade: dimensões de una privacidade possível”. In: Nicolau Sevocêenko (Org.). "História da vida privada no Brasil”. São Paulo: Companhia das Letras, 1998.

SILVA, Celma Fernanda T. de Almeida e. Barbarie en la Democracia: Percepción de la práctica de la tortura en Brasil a la luz del discurso de los derechos humanos: el caso de Pernambuco. Salamanca: Ediciones Universidad Salamanca, 2006.

SILVA, José Geraldo da. "A lei de tortura interpretada: comentários à lei 9.455 de 07 de abril de 1997”. Leme: Editora de Direito, 1997.

SKIDMORE, Thomas. "Brasil: de Castelo a Tancredo, 1964-1985”; Trad. C2 Salviano Silva. - Rio de Janeiro: Paz e Terra, 1988.

SKOLNICK, Jerome. “Justice without trial”. Nueva Yorque: Jonh Wiley and Sons, 1966.

. "Why cops behave the way they do". New York World Journal Tribune, 1966.

SOARES, Luiz Eduardo. "Meu casaco de general: 500 dias no front da segurança pública no Rio de Janeiro”. São Paulo: Companhia das Letras, 2000.

- "A polícia do futuro: A força policial é a única das instituições nacionais que não foi reformada após o fim da ditadura”. In: Super Interessante especial segurança: Por um Brasil menos violento. Ed. Abril, pág. 26, Abril de 2002.

SOLÓRZONO, Luis de la Barreda. Tortura: la intensidad del dolor. In: Criminalia. Academia Mexicana de Ciencias Penales. Año LXX, no. 1. México: Porrúa, 2004. (Enero-Abril).

STADEN, Hans. “Duas viagens ao Brasil”. Porto Alegre: L\&PM Editores, 2008.

STUBBS, Michel. Análisis de discurso: análisis sociolinguístico del lenguagen natural. Madrid: Alianza Editorial, 1987. 


\section{Dimensiones histórico-sociológicas de la tortura en comisarías de Brasil: el caso Pernambuco}

SUMAlla, Josep María Tamarit. Comentarios al Código Penal: Tomo I, Parte General (Articulos 1 a 137). Fermín Morales Prats (Coord.). Navarra: Aranzadi, 2008.

SZNICK, Valdir. “Tortura”. São Paulo: Leud, 1998.

TERESTCHENKO, Michel. "Du bon usage de la torture: ou comment les démocraties justifient l'injustifiable". Paris: La découverte, 2008.

TOMÁS Y VALIENTE, Francisco. La tortura judicial en España. Barcelona: Crítica, 2000.

TONRY, Michael \& MORRIS, Norval (Orgs.). "Policiamento moderno". Trad. Jacy C. Ghirotti. - São Paulo: Editora da Universidade de São Paulo, 2003. (Série Polícia e Sociedade; n. 7).

TORQUATO, Gaudêncio. “Cultura, poder, comunicação e imagens: fundamentos da nova empresa”. São Paulo : Pioneira, 1991.

VAN DIJK, Teun A. Texto y contexto: semántica y pragmática del discurso. Madrid: Cátedra, 1980.

Algunos principios de una teoría del contexto. In: ALED, Revista latinoamericana de estudios del discurso1(1), 2001, pp. 69-81.

VELLASCO, Ivan de Andrade. "Policiais, Pedestres e Inspetores de Quarteirão: algumas questões sobre as vicissitudes do policiamento na Província de Minas Gerais (1831-50)”. In: CARVALHO, José Murilo de. (Org.). Nação e Cidadania no Império: novos horizontes. Rio de Janeiro: Civilização Brasileira, 2007.

VERDUGO, Patricia. (Org.). De la tortura no se habla Agüero versus Meneses. Santiago do Chile: Catalonia, 2004.

VERRI, Pietro. Observaciones sobre la tortura. Trad. Manuel de Rivacoba y Rivacoba. Buenos Aires: Depalma, 1977.

VITTORI, Jean-Pierre. “On a torture en Algérie”. Paris: Éditions Ramsay, 2007. 


\section{Dimensiones histórico-sociológicas de la tortura en comisarías de Brasil: el caso Pernambuco}

WAGNER III, John A. \& HOLLENBECK, John R. "Comportamento Organizacional: criando vantagem competitiva”. Trad. Cid Knipel Moreira - São Paulo: Saraiva, 2003

WALZER, Michael. "Political action: the problem of dirty hands". Philosophy and Public Affairs.Vol.2, n. 2, 1973.

WESTLEY, William A. "Violence and the police: a sociological Study of Law, custom and morality”. Cambridge: 1970.

WISSENBACH, Cristina Cortez. "Da escravidão à liberdade: dimensões de una privacidade possível”. In: Nicolau Sevocêenko (Org.). História da vida privada no Brasil. São Paulo: Companhia das Letras, 1998.

ZALUAR, Alba. "A máquina e a revolta: as organizações populares e o significado da pobreza”. São Paulo: Brasiliense, 1985.

. “Cidadãos não vão ao Paraíso”. São Paulo: Excuta; Campinas, SP: Universidade Estadual de Campinas, 1994.

- "Para não dizer que não falei de samba: os enigmas da violência no

Brasil”. In: Fernando A. Novais (Coord.); Lilia Moritz Schwarcz (Org.). São Paulo: Companhia das Letras, 1998.

ZIZEK, Slavoj. "Knight of the living dead”. New York Times. 24 de marzo 2007.

ZULEIKA, Alvim. "Imigrantes: a vida privada dos pobres do campo". In: Nicolau Sevocêenko (Org.). História da vida privada no Brasil. São Paulo: Companhia das Letras, 1998.

\section{PUBLICACIONES ON-LINE:}

AMARAL, Luiz Otavio O. Direitos humanos e violência policial. una polícia menos letal: o profissionalismo policial. Jus Navigandi, Teresina, ano 7, n. 63, mar. 2003. 


\section{Dimensiones histórico-sociológicas de la tortura en comisarías de Brasil: el caso Pernambuco}

Disponível em: 〈http://jus2.uol.com.br/doutrina/texto.asp?id=3794>. Acesso em: 24 jun. 2008.

CEAP. Violência policial: não. Cartilha de defesa de direitos humanos contra a violência policial: http://www.dhnet.org.br/dados/cartilhas/dh/br/rj/cart_violpol.htm - acceso en 20/08/2011.

COIMBRA, Cecília Maria Bouças. Tortura ontem e hoje: resgatando una certa história. Psicol. estud., Maringá, v. 6, n. 2,2001 . Disponível em: $<$ http://www.scielo.br/ $\quad$ - $\quad$ scielo.php?script=sci_arttext\&pid=S1413$73722001000200003 \& \operatorname{lng}=$ pt\&nrm=iso $>$. Acceso em: 21 Jun 2008. doi: 10.1590/S1413-73722001000200003.

FOLHA DE SÃO PAULO. ON LINE - acceso en 15/12/08 http://www1.folha.uol.com.br/folha/cotidiano/ult95u477333.shtml KEHL, Maria Rita. Torturar, por que não? 01/05/2011 - acceso en 20/12/2011 http://www.estadao.com.br/noticias/impresso,tortura-por-que-nao,545397,0.htm FRIAS-ARMENTA, Martha; LOPEZ-ESCOBAR, Amelia Eréndida; DIAZMENDEZ, Sylvia Guadalupe. Predictores de la conducta antisocial juvenil: un modelo ecológico. Estud. psicol. (Natal), Natal, v. 8, n. 1, Apr. 2003 . Available from <http://www.scielo.br/scielo.php?script=sci_arttext\&pid=S1413294X2003000100003\&lng=en\&nrm=iso>. access on 22 Feb. 2012. http://dx.doi.org/10.1590/S1413-294X2003000100003 - Acceso en: 05/08/2010.

MICHAELIS. Moderno dicionário da língua portuguesa. Acceso en 12/09/11 http://michaelis.uol.com.br/moderno/portugues/index.php?lingua=portugues-

portugues\&palavra=macho

PERNAMBUCO.COM.

http://www.pernambuco.com/ultimas/nota.asp?materia=20120410221901\&assunto= 27\&onde $=$ Politica - acceso en 11/04/2001.

RAE. Real Academia Española. www.rae.es - acceso en 20/01/2009. 
Dimensiones histórico-sociológicas de la tortura en comisarías de Brasil: el caso Pernambuco

TERRA. http://noticias.terra.com.ar/internacionales/indemnizado-en-alemania-elasesino-de-un-nino-por-abuso-policial, acaa294d1a591310VgnVCM4000009bf154d0RCRD.html 


\section{Dimensiones histórico-sociológicas de la tortura en comisarías de Brasil: el caso Pernambuco}

\section{NOTAS DE TRADUCCIÓN DE LAS ENTREVISTAS}

\footnotetext{
i - "vá à merda você e essa cambada de acadêmicos que ficam se masturbando com estes conceitos elitistas de dignidade humana, hipócritas!” (C2).

ii - "A polícia deve ter um discurso não só de combate à tortura, mas de construção de una nova missão para a polícia e de um novo papel par ao policial”. Isso creio que ainda estamos há anos luz, porque isso só poderia acontecer com a efetiva participação da sociedade. E a sociedade ainda esta interessada em manter una tolerância para os atos corruptos e consequentemente com a tortura. Creio que trabalhos dessa natureza podem vir a colaborar pelo menos para se tiver um diagnostico um pouco realista sobre o tema nas instituições. (CA5).

iii - "Ocorreu meio por acaso, mas ao ingressar nos quadros mediante concurso, procurando estabilidade financeira, acabei gostando da profissão”. Preguntándole por que renunció a salir, contestó: "tive vontade de sair em alguns momentos, quando vivenciei situações difíceis na Polícia e não me sentia devidamente valorizado". Entrevista en agosto/2011 - por mail.
}

iv - "A sociedade hoje, infelizmente, não é mais como nos anos 60, a polícia não impõe mais respeito. Se você chegar em um determinado lugar e os policiais forem minoria, em um lugar violento, eles vão soltar piadinha, não vão obedecer, porque a polícia não impõe mais respeito. Não é como na Europa ou Inglaterra que a polícia vai desarmada... Lá, a figura do policial já impõe respeito. No Brasil você não tem isso. Se você chegar em determinado lugar em minoria, não vai ser respeitado, suas ordens não vai ser acatadas. Então hoje a polícia, muitas vezes dá resultado, infelizmente, mas através do medo. $O$ bandido tem medo que o policial bote a porta dele abaixo, machuque alguém que ele goste, haja de forma violenta com ele. Então ele entende isso. Mas ele não respeita a polícia, a polícia é temida. Então os policiais tentam manter esse aspecto, porque é melhor ser temido do que você não chegar ao resultado."

v - "influencia do meu pai que era policial e também do ambiente militar onde trabalhei antes".

vi - "bandido só vai no cacete”.

vii - "Sinto saudade, sinto saudade. Porque hoje..., vou ser bem claro, as pessoas não respeitam mais, as pessoas hoje chegam na delegacia se achando, no mesmo direito, mesmo tando errado. Não respeitam o policial de plantão, não respeitam o delegado de plantão. Qualquer coisa procure meu advogado... coisas que na época não acontecia... o cara vinha mesmo e, se chegasse aqui $e$ aumentasse a voz, era xadrez, dois, três dias... era uma lição pra ele se enquadrar... (A3)".

viii - "Conheço, conheço”. 


\section{Dimensiones histórico-sociológicas de la tortura en comisarías de Brasil: el caso Pernambuco}

ix - "Sim. Em convívio pessoal”.

x - "Conheço vários. Agentes e delegados. Alguns que praticam ocasionalmente, outros frequentemente e, até um delegado psicopata. Sem falar naqueles que sabem que os agentes praticam e fingem que não sabem nada”. (C3).

xi - "Tem, infelizmente ainda existem policiais com esse tipo de entendimento... Conheci e já ouvi falar. Veja, tem alguns que pelo que ouvi, na cabeça deles eles só conseguiriam desvendar aquele crime com a informação do autor, então por isso que eles tentavam por essa prática obter a informação. Tem um outro que eu acredito que deve ter algum distúrbio. Por que ele faz coisas que não são necessárias que ele faça. E assim, não tem uma justificativa assim. É como se fosse só mesmo a questão de fazer bem a ele, ver o outro ser submetido a determinados sofrimentos físicos". (CA6).

xii - "Sim. Soube através de outros policiais. Em nossa instituição há policiais que se tornaram famosos e até respeitados pelo uso da tortura". (C4).

xiii - "Sim, quase todos os policiais quando não tem elementos científicos probatórios suficientes para formular um texto investigatório, acabam por recorrer a praticas de "interrogatórios" violentos ou a abandonar a investigação por falta de opção”. (CA5).

xiv - "Sim, conheço alguns policiais que se notabilizaram pelo uso da tortura e ainda são aplaudidos por essa prática”. (C13).

xv _ "Conheço, delegados, agentes”. (A1).

xvi - "Conheço comissário, agente, delegado que aplica realmente a tortura. Aí a pessoa confessa que matou até Jesus Cristo”. (A4).

xvii - “Conheço, agentes, delegados, comissários, policias militares”. (A2).

xviii - "Conheço. Alguns dos meus policiais. Os melhores, como disse antes, são os que praticam tortura. De início rejeitei a idéia, mas eles me convenceram que só agindo assim, fluíam as investigações”. (C12).

xix - "Já. Eu entrei na polícia algum tempo atrás e no estágio eu entrei numa delegacia especializada, não era nomeado ainda, e vi. Mesmo o policial sabendo que estavam por ali pessoas que estavam para ingressar nos quadros da polícia, não teve a menor cerimônia de parar, esconder. (...) Presenciei, eu trabalhei numa delegacia de plantão onde tinha um cara que batia nas pessoas por tudo. Até por botar um pé no banco. Por exemplo, ele achava que era coisa indevida, feia, aí ele corrigia a pessoa torturando...” (Cl).

xx - "Sim. Com normalidade tendo em vista a necessidade de resultado esperado”. (C2).

xxi - "Sim, logo nos primeiros contatos com a prática policial, era quase um "brinde" ser levado para assistir ou colaborar com una sessão de tortura para aprender a ser um policial duro. A reação imediata foi pedir para sair. Mas fui imediatamente tachada de "boazinha" $e$ de "covarde", $e$ evidentemente de mal policial. Não servia para ser policial, pelo menos não me adequava ao molde de policia daquela época”. (CA5). 


\section{Dimensiones histórico-sociológicas de la tortura en comisarías de Brasil: el caso Pernambuco}

xxii - "Já. Só uma vez. Foi em una cidade do interior de Pernambuco onde eu era delegado. Quando fui conversar com o oficial da PM da cidade, ele estava no presídio, e quando eu encontrei ele, ele estava torturando um preso que havíamos prendido há alguns dias”. (C3).

xxiii - "Nunca presenciei não. Eu realmente acho que nunca quis pensar nisso não. Mas assim, eu acredito que eu vou tentar impedir que aquilo aconteça... e sinceramente não sei como seria o desenrolar, se eu iria formalizar aquilo para que fosse apurado, não sei, ia depender da situação eu acho, realmente eu não sei”. (CA6).

xxiv _ "Não". (C4).

${ }^{\mathrm{xxv}}$ - "Certa feita tive que impedir uma tortura. Os policiais não reagiram porque sou delegado, mas certamente, se fosse do mesmo nível funcional deles não teriam cedido e ainda teriam reagido violentamente". (C13).

xxvi - "No início da carreira sim e rejeitei a situação. Hoje sei que torturam, não gosto, mas vejo necessidade em muitos casos. Nunca torturei, apenas permiti, no entanto, alguns tapas no rosto dei, mas não surtiram efeito". (C12).

xxvii - "Já. Como eu tenho já relativamente um certo tempo de polícia, então eu já participei, já pratiquei. Tá entendendo. E assim, quando eu não pratiquei e participei, assisti”. (A1).

xxviii _ “Já. Bem, a priori, a minha reação logo quando entrei na Polícia Civil... Você tem aquela coisa, você leva aquele susto. É assim que funciona? Era essa imagem que eu tinha da policia pra chegar nos resultados? Mas depois vem aquela coisa pessoal, aquela busca pelo resultado. Você vê que aquilo em determinados casos chegou ao resultado satisfatório. $O$ uso da força fez com que você realmente, diretamente praticasse a justiça. Porque você usou a força pra chegar a determinado fime através daquela força você realmente chegou naquele determinado fim... Então a priori era uma coisa que me incomodava, mas depois passou a fazer parte do serviço. Em determinados casos específicos o uso da força era necessário pra chegar em determinado fim”. (A2).

xxix - "Já, já presenciei. Era muito espancamento mesmo. Os amigos davam choque, botavam na cadeira amarrado, aquela coisa de saco, pau-de-arara... Isso tudo eu vi porque passei por delegacias que era comum isso de madrugada...” (A4).

xxx - "A violência era corriqueira. A prática na época, de se tirar serviço, era sempre usar violência. Também tinha tortura psicológica, mas a maioria era física. O método é geralmente saco porque saco geralmente não deixa marcas...” (A3).

xxxi - "É, Não me comovi, não quis que parasse, não repreendi quem fazia, sendo imediato, parte, superior ou subordinado. E, sempre as vezes que presenciei essa foi a minha reação”. (A1).

xxxii - "Desconforto, pena do ser humano sendo espancado" (A4).

xxxiii - "Quando se tratava de um crime que eu achava que a pessoa merecia, então eu também aceitava”. (A3). 


\section{Dimensiones histórico-sociológicas de la tortura en comisarías de Brasil: el caso Pernambuco}

xxxiv - "Na PM. Na PM sim. Eles diziam: tu não sabe porra nenhuma não novinho. Tu tem que aprender novinho. Então sempre as repreensões eram de cunho, de forma a me marginalizar do grupo. Eles tocavam numa ferida, porque quem é novinho não quer ser chamado de novinho. Você quer ser parte do grupo, você quer ser parte importante do grupo, então quando eles tocavam nesse ferida. Já vi que é muito abafado, já vi que é frouxo, já vi que tinha que ser recruta. Então mexia no ego, de forma a marginalizar, e de certa forma dizer apoia que tu é do grupo. Você não entende nada, você não está apto a ser polícia”. (Al).

xxxv - "Quando eu entrei aqui, logo no começo, no departamento eu era forte e aí o cara dizia, novinho você vai bater em fulano. Aí eu chegava e dizia pro preso, eu vou bater devagar e tu grita bem muito. Eu vou bater no birô, na parede e tu grita. E aí eu dizia que não saiu nada. $O$ diretor, que já morreu, uma vez me disse rapaz você só tem tamanho, força e moleza. Pra que esses músculos todinho se não serve pra bater em ninguém. Aí eu chegava em casa e dizia: vou sair da polícia, vou optar pela educação. Mas aí, toda vida pagou muito pouco a educação. E aí eu acabava ficando mesmo". (A4).

xxxvi - "Como novinho eu não podia”.

xxxvii - "Tem de todo tipo. Tem aquele que fecha os olhos, tem um crime, uma investigação em andamento, tem um suspeito, o delegado sabe que ele vai ser torturado e fecha os olhos. Para mim, isso é participação, ou seja, ele sabe que estão tirando serviço, essa expressão muito usada, que quer dizer, torturar. Tem esse que não suja a mão e tem aquele que participa, que é bem menor o número, e faz para mostrar a tropa que ele é um cara que tem que ser respeitado porque ele é capaz de fazer aquilo”. (C1).

xxxviii - "Na maioria das vezes dá indicativo tácito da necessidade do recurso da tortura ou tem conhecimento que o método a ser usado era esse e espera as informações obtidas”. (C2).

xxxix - "Pela minha experiência, tem policial que tá tão inserido no dia a dia dele aquela prática, não só da tortura como de outras irregularidades, que ele só sabe trabalhar daquele jeito. Então se ele vai para una unidade onde a prática do delegado titular, o chefe dele, não é dessa forma, ele procura outro canto para ir porque ele sabe que ele não vai ter aquela continuidade e ali não dá para ele... Tem um outro, não... Tem um outro, não, que a pesar dessa prática ele se amolda a prática do chefe dele, então assim, ele sabe até onde ele pode ir com aquele delegado, ele sabe que aquela parte ali ele não pode ultrapassar. Porque ele não vai ter apoio, ao contrario, ele vai ser comunicado, se aquela situação for descoberta ele vai ser afastado e vai responder, porque o chefe dele vai comunicar o que ele fez". (CA6).

${ }^{\mathrm{xl}}$ - "Tem aqueles que participam diretamente para mostrar à equipe que é durão. Tem aqueles que não têm coragem para fazer, mas querem que os agentes façam. Tem aqueles que nem têm coragem para fazer, nem coragem para assumir as consequências, então finge que não sabe que os agentes fazem, para não se envolver. Se der merda ele vai dizer que não sabia de nada. Não sabia o que o agente queria dizer com: 'posso tirar o serviço doutor?'”. (C3).

xli _ "Tenho conhecimento das três formas de participação: praticando diretamente, mandando que se pratique a tortura ou simplesmente se omitindo, desde que o caso seja solucionado. Tais posturas existem mesmo com delegados que ocupam cargos de gestão de polícia”. (C4). 


\section{Dimensiones histórico-sociológicas de la tortura en comisarías de Brasil: el caso Pernambuco}

xlii _ "Depende do perfil do Delegado. Há perfis para todos os gostos. Em geral, estimula, apóia, mas não participa diretamente. Muitos não "sujam" as mãos diretamente, mas são permissivos com as praticas e até mesmo impõem um certo "limite” para controlar a vigilância externa”. (CA5).

xliii - "Pronto, então, já participei e já vi várias posturas. Aquele que se omitia e dizia eu não tô vendo nada, mas também se explodir a culpa é tua.. Já vi aquele que não participava efetivamente, mas também não proibia, tinha ciência. Que pra mim era o pior. Das espécies pra mim era o pior. Porque também tinha aquele que era efetivo, era ele que dizia: olha e primeira tapa é minha e o que der eu seguro. Como deu em algumas situações e ele segurou. Aconteceu algumas situações... E de grande proporção, e ele foi macho e segurou. Como tem outros que também aquele que só quer os louros. Ele incute na cabeça dos policiais que ele é contra, mas que os policiais podem fazer em busca de um resultado plausível pra ele delegado, mas no dia que a bomba estourar, ele delegado, vai dizer que não sabe, até porque não tem nenhuma ordem por escrito. E o policial, é aquela história, só quem cai é o torturador, o mentor nunca cai”. (A1).

xliv - "Realmente a participação do delegado é a omissão. É tipo, vou soltar meus melhores cães de caça à procura de determinada presa, pra chegar a determinado fim. E o que eu vou dar a eles é carta branca para eles trabalharem. Não vou participar, não vou botar a mão naquilo, mas eu sei o que eles estão fazendo. Eu sei que pra chegar nesse resultado eu tô dando total apoio indireto. Mas eu não vi nenhum delegado que ele praticasse a força”. (A2).

xlv - "Tem uns que vão. Tem uns que fingem que não vê, sabe de tudo, mas na hora de cair diz que não sabe de nada, que não viu. Dizem mesmo, se acontecer isso aí eu não tava aqui. Façam, se der certo deu, mas se não der, responda cada um pelos seus atos”. (A4).

xlvi - "Alguns participavam diretamente e outros não queriam saber a forma como aconteceu. Queriam o resultado”. (A3).

xlvii _ “Que eu me lembre, não”. (A3).

xlviii - "Já, principalmente hoje em dia, na realidade da Polícia Civil, é bem mais comum você encontrar delegados que valorizam a investigação, inteligência, que o uso da força. Só recentemente que trabalhei com um delegado que ele era, justamente, totalmente o contrario. Era ex militar, recém formado, então ele dizia: "polícia é tapa, tiro e mão na cara. É o que a bandidagem merece". Ele era o próprio líder da equipe e por isso a equipe era influenciada por ele. Durante alguns meses a equipe deu resultado, mas trabalhando dessa forma. Deu resultado e prosseguiu durante algum tempo. Até que a equipe foi desmembrada por outras razões administrativas, não relacionadas com a tortura. A filosofia deste delegado era trabalhar com o uso da força”. (A2).

xlix - "Diversas vezes. E assim, vários momentos eu me manifestei contra. Dizia, 'oh, parou, não vai rolar mais', porque eu via que estava tomando uma proporção que o próprio torturador não tinha mais controle. É quando fica perigoso”. (A1).

${ }^{1}$ - “O que eu podia fazer para aliviar aquela tortura eu fazia... por exemplo, não apertava muito, perguntava se queria água, aquela de dizer, rapaz infelizmente o sistema é assim, porque você não colabora... Já discuti mesmo com um colega porque o cara já tinha abrido o jogo para mim e o meu colega foi lá bater nele e eu disse pra que isso se ele já colaborou. Ai criou esse mal-estar entre eu e o colega e inclusive até hoje não nos falamos... Geralmente íamos as 3 ou 5 da manha buscar 


\section{Dimensiones histórico-sociológicas de la tortura en comisarías de Brasil: el caso Pernambuco}

bandido, então era importante estar de bem com os colegas por que senão alguma coisa podia dar errado... então eu não gostava de ver os colegas derrubando portas, arrastando pessoas, mas eu procurava me juntar com outros colegas que pensavam parecido e agente procurava acalmar os mais violentos". (A4).

li - "Quando se tratava de um crime que eu achava que a pessoa merecia, então eu também aceitava”. (A3)

lii _ "Todos ou a grande maioria. Quando entrei era a cultura geral que prevalecia era a da violência. Claro que havia exceções, mas era a minoria quase não identificada. Os chamados “intelectualizados" estavam sempre no ostracismo, também tinham medo de se revelarem e pagarem por isso e não gozarem dos privilégios que o poder sempre está a oferecer" (CA5).

liii - "A grande maioria praticava”. (C1).

liv - "Os que toleravam chegam a setenta por cento, tentando demonstrar que não sabiam da ocorrência transferindo a responsabilidade para a equipe policial”. (C2).

lv _ "Mais da metade deles (praticavam)". (C4).

lvi - "Eu conheço delegados que praticam diretamente e tem alguns que utilizam o policial subordinado para fazer, mas tem conhecimento”. (CA6).

lvii - "Eu creio que a minoria tortura. Não sei dizer. Agora estava pensando em meus colegas mais próximos e a maioria não tortura, nem admite que seus policiais torturem. Mas quando eu penso em outros grupos na polícia, creio que essa relação se inverte. Eu conheço grupos de delegados em que a exceção são os que não praticam”. (C3).

lviii - “A proporção era enorme, não tenho idéia, no entanto, eu não fazia e com isso, nada de sucesso na área”. (C12).

lix _ "Mais da metade dos que trabalhavam na área operacional”. (C13).

lx - "A imagem que nos é vendida é de que antigão é torturador, novinho não é torturador. São os legalistas, ao extremo! E agente entra com isso e até a nossa predisposição de trabalhar é com os novinhos porque a gente não quer se bronquear, essa é a palavra, porque agente tá ainda no probatório e agente não quer se bronquear, mas na verdade isso é meio lendário porque existe muito antigão legalista e muito novinho que tá no acelerado. Acho que assistiu muito Tropa de Elite e ainda tá no acelerado”. (A1).

lxi - "Hoje se pratica menos que antes. Se você pegar uma época aí dos anos 80, da ditadura. A própria parte dos direitos humanos é mais visada hoje que antes... Hoje o policial tem essa consciência de que se for pego ele vai ser punido”. (A2).

lxii - "Hoje melhorou muito, desses 30 anos para cá. Por conta dos estudos, a cabeça dos delegados é melhor. Quando entrei era mais de $50 \%$ e hoje $10 \%$... Você as vezes que respeitar a pessoa. Mas tem bandido que não que respeitar ninguém. Não respeita pai, não respeita mãe, não respeita parente, 


\section{Dimensiones histórico-sociológicas de la tortura en comisarías de Brasil: el caso Pernambuco}

não respeita ninguém. Então tem que respeitar alguém. Esse alguém tem que ser a polícia. Aí a gente faz isso..." (A4).

lxiii _ “(...) as mulheres torturam menos, é um fato, embora que há torturadoras mulheres e muitas vezes aqueles homens que não aderiam à tortura eram considerados muito ('), tímidos em excesso na sua vida social e não aderiam até mesmo por um defeito de caráter, digamos assim, não eram operacionais. O operacional em um determinado tempo na polícia significava também aquela pessoa disponível para usar a tortura”. (C1).

lxiv - "Com certeza homens. Acho que a força masculina ela impõe. Primeiro que a mulher é mais sensível a ver sangue, a lesão, esse tipo de coisa, na minha percepção. O homem pela força física ele acredita, tem até o velho ditado que diz: pau que não resolve é quando o pau é pouco. Então acredita-se que enquanto ele não diz se você cada vez agrava mais a prática da tortura porque acredita que o pau foi pouco”. (C14).

lxv - "Os homens. O hormônio da testosterona diz muito. São poucas as mulheres que o fazem, porém existem muitas que permitem". (C12).

lxvi - "Os homens, pois os métodos com frequência exigem força física. Mas muitas mulheres são tolerantes ou incentivam”. (C13).

lxvii - "Sim. Em caso de terrorismo e crime organizado, nos casos de quadros criminosos mais violentos". (C2).

lxviii - "Não é possível associar a tortura a determinado tipo penal, mas alguns como extorsão mediante sequestro, roubo a banco e carro forte é mais comum sua utilização. Os policiais que utilizam essa pratica dizem que esses criminosos são mais rusticos e não conhecem outra linguagem”. (C13).

lxix - "Em alguns tipos de tráfico para provar a materialidade e não existindo interceptação, sim. Muitos traficantes não vão confessar apenas na conversa para dizerem onde está a droga”. (C12).

lxx - “Sim. Entorpecentes por exemplo”. (A1).

lxxi - "Não vislumbro esta hipótese”. (C4).

lxxii - “Não. Nunca”. (CA5).

lxxiii - "Na verdade entendo, face a realidade de condições, que os crimes contra o patrimônio demonstram uma certa necessidade de violência no trato com os criminosos, e trazem consigo um certo código de honra, e a pressão pelo resultado imediato nos crimes desta natureza apontam para métodos deste tipo". (C2).

lxxiv - "Digamos assim, que a vida de una terceira pessoa estivesse em risco. Um seqüestrador que mantém a vida da pessoa que vai morrer, mas isso é una coisa pontual que o cara vai ter que resolver sozinho. A instituição não pode defender a conduta. Tem que mudar a lei, porque muitas vezes as pessoas confundem a tortura no dia a dia na cadeia, no sistema penitenciário, nas delegacias, com a tortura terrorista, soa assuntos muito complexos". (C1). 


\section{Dimensiones histórico-sociológicas de la tortura en comisarías de Brasil: el caso Pernambuco}

\footnotetext{
Ixxv - "Para salvar una vida. Em legítima defesa ou Estado de necessidade”. (C3).

lxxvi _ "Não. Eu tenho 11 anos de polícia e nunca trabalhei usando dessa prática...” (CA6).

lxxvii - "A tortura é utilizada para obter confissão da prática de um crime ou para penalizar a pessoa da qual se tem certeza de que praticou um crime. Não vislumbro, em ambas as hipóteses, um tipo penal que justifique tal prática”. (C4).

lxxviii _ "Não, para mim nenhum crime é passível de ser investigado por meio da tortura”. (CA5).

lxxix - "Hoje em dia não mais, porém, quando se há denúncia de tráfico e vc apreende apenas uma pedra, na maioria das vezes o suspeito entrega o restante da droga por meio de tortura, não tenho dúvida. Caso contrário, responderia como usuário e voltava a traficar, prejudicando muitas famílias”. (C12).
}

Ixxx - "Não”. (C13).

lxxxi - "Sim. Entorpecentes por exemplo”. (Al).

Ixxxii _ "Tem uma frase que ouvi que dizia o policial também tem medo, tem filhos. Então você vai pra uma ocorrência em que foi estuprada uma garota de idade de sua filha... o policial não consegue separar, ele se envolve na ocorrência com o seu emocional... é como um desabafo para o policial, pois o cara comete um crime bárbaro e só vai passar 5 o 4 anos e vai ser solto. $O$ policial não aceita isso... Então ele realmente se envolve em atos de violência, não só para chegar ao resultado”. (A2).

lxxxiii - "Alguns tipos de crime: Acredito... Elementos que merecem ser torturados por que eles hoje se aproveitam, e a lei favorece, e deixam você ir até o ultimo recurso para se você tiver competência intelectual e material de trabalho aí você vai descobrir, senão, ele vai ficar calado até a conclusão do inquérito, da investigação. Se não conseguir provar ele vai ser favorecido. E tem pessoas que que só vai no cacete, é da índole da pessoa. Não diz, de jeito nenhum, só diz se apanhar. Mas infelizmente, ou felizmente hoje em dia não se pratica mais" (A3).

lxxxiv _ "Não. Acho que não” (A4).

lxxxv _ "Na Capital. Devido à demanda e a pressão” (C2).

lxxxvi - "Acho que no interior. Por estar mais distantes dos órgãos fiscalizadores” (C4).

lxxxvii - "Eu não sei contabilizar se um é maior que outro não, mas eu sei que tem nos dois, na Capital e no interior" (CA6).

lxxxviii - "Na PC é complicado dizer isso, não dá para ter idéia. Eu acho que no interior pratica mais... agora é muito complicado dizer isso" (C1).

lxxxix - "Não sei dizer. Tenho a impressão que nas delegacias especializadas (estão na Capital) se pratica mais. Mas é só una intuição” (C3). 


\section{Dimensiones histórico-sociológicas de la tortura en comisarías de Brasil: el caso Pernambuco}

xc - "Se pratica onde há menos controle e onde a sociedade tem menos acesso" (CA5).

xci - "Na Capital, onde ficam as delegacias especializadas que estão preocupadas em apresentar resultado" (C13).

xcii - "Na região metropolitana, onde vive maior parte da população pobre. Mas digo isso não por ser pobre e sim por não poder contar com advogado que o defenda, como os ricos” (C12).

xciii - "No interior, no sertão. Onde a polícia está fechando os olhos pra isso. Porque além de não existir uma fiscalização como existe na Capital, porque na Capital você tem a corregedoria, você tem câmeras em todo lugar, você tem pessoas com melhor instrução, e no interior, o que é que você tem? No interior você tem um cara que provavelmente não chegou na segunda série, mal sabe assinar o nome, que não conhece nada dos direitos humanos, que pra ele levar uma tapa de um policial faz parte do trabalho policial. Você chega em Recife, o bandido, por mais "pé rapado" que seja ele tem uma noção da coisa. "Eu só bandido, mas você não pode encostar em mim, eu tenho os direitos humanos, eu tenho advogado”. No interior, bandido não tem essa visão, então pra ele levar um pau da polícia tá mais do que certo, é o trabalho da policia...” (A2).

xciv _ "Na Capital, porque a violência é maior na Capital” (A4).

xcv _ "Capital, porque tem um volume maior de trabalho" (A3).

xcvi - "Sim" (C2).

xcvii - "Já” (Cl).

xcviii - "Eu propriamente, não. Alguns tapas nas costas e no rosto, sim, mas nada que ferisse o investigado”. (C12).

xcix - "Não" (C13).

c - “Já, infelizmente já” (A4).

ci - “Já. Algumas vezes. Não tanto corriqueiramente como na PM” (A2).

cii - "Praticava, algumas vezes sim” (A3).

ciii - "Só quando for necessário para a investigação" (C15).

civ - "Já" (A1).

cv - "Caso de estupro de criança ou idosos. Fazer barbaridade. Realmente eu tenho pavor a esse tipo de gente. Então nesses casos eu procuro nem me aproximar para não perder a razão” (A4).

cvi - "Ainda não parei, mas repito, a violência praticada por mim é levíssima. Não pratico 'saco', choque e sim tapinhas, porém, permito o primeiro com restrições” (C12).

cvii - (C2 no quiso contestar esa pregunta). 


\section{Dimensiones histórico-sociológicas de la tortura en comisarías de Brasil: el caso Pernambuco}

cviii - "Como disse anteriormente, você vê que não vale a pena o resultado que você chegou. Por melhor que tenha sido, por mais satisfatório o trabalho profissional, mas e sua moral? E seu bem estar? Você botar a cabeça no travesseiro e dormir... Então quando chega a esse ponto, valeu a pena?... Então você vai ter que mudar os meios... Será que existe uma forma mais inteligente de chegar ao resultado?” (A2).

cix - "Hoje eu já encontro, mas não tem os meios, os aparatos, nem o apoio necessário... Você tenta, mas a polícia não te dá isso... Então você tende a evitar chegar naquele caminho, mas é extremante difícil porque a cobrança permanece a mesma, polícia não quer saber que você mudou seu pensamento. Não quer saber de teoria, nem de filosofia. Ela quer saber que você não está dormindo. Ela quer o resultado. A cobrança continua e você fica naquele beco sem saída. Aí é quando ocorre o que está ocorrendo com boa parte dos policiais. Eles entram, não concordam, e vão embora... Você não vai mudar o sistema da Polícia Civil? Você não vai. Então a única solução que você tem é ir embora" (A2).

cx - "O resultado vai ter que chegar. De uma forma, ou de outra. Eu entendo agora que vai ser de uma forma gradativa. Você não pode radicalmente mudar. Então, a principio você vai ter que ser maleável... Eu pretendo mudar, mas eu sei que não vai ser fácil, nem dá pra dizer: eu não pratico isso nunca mais, nem de forma nenhuma. Eu não sou tao radical. E admito que em determinados casos possa ser que eu use desse recurso" (A2).

cxi - "A consciência”. (A4).

cxii - "Eu acho que deve ter sido amadurecimento para saber que, primeiro de tudo tem una conseqüência, para o próprio torturador" (C1).

cxiii - "Eu acho que são as conseqüências do próprio ato” (C1).

cxiv - "Eu nunca torturei. Mas antes eu ficaria contente de ter um agente que pudesse torturar, embora nunca tenha encontrado em todas as delegacias que trabalhei. Nem eu nunca tive coragem para pedir a eles, nem o contrário, eles pedirem autorização para torturar. Eu sentia falta de não dispor deste recurso. Ter una reserva estratégica para os casos mais complicados... Hoje, não. Hoje eu não quero essa facilidade. $O$ que houve? Não sei... Amadurecimento talvez... Não sei... Talvez a preocupação com os resultados também tenha diminuído... Talvez a aproximação com alguns grupos mais legalistas que me rechaçariam se soubessem que eu era tolerante com isso... Realmente, não sei" (C3).

cxv - "Continua. Mas com mais pudor. Eu quero os resultados, mas não a qualquer preço” (C3).

cxvi - "Continua o mesmo, porem sem preocupações de reconhecimento institucional, e sim resultado prático perante a sociedade” (C2).

cxvii - "Os resultados são buscados, não importam os meios. Como disse antes, sim” (C12).

cxvii - "Primeiro procurei obter através de rede de informantes e depois com modernas técnicas de investigação, como a interceptação telefônica” (C13). 


\section{Dimensiones histórico-sociológicas de la tortura en comisarías de Brasil: el caso Pernambuco}

cxix - "Na medida que o tempo vai passando você vai alcançando uma maturidade onde se incialmente você estava preocupado com o que achavam de você, como a instituição iria lhe acolher, com o passar do tempo você passa a se preocupar com os próprios valores. A instituição passa a ficar no segundo plano. E ele vai entendendo que no dia que ele for ineficaz ele vai ser substituído” (A1).

cxx - "No primeiro momento eu acho assim, que naquele dia a dia, na cabeça dele ele acha que só consegue assim, daquela forma. E é como se o cara, até por ser um contumaz naquela prática, ele até já estivesse acostumado, sabendo que tipo a polícia vai pegar, ela vai passar por aquilo. Naquele momento ali, naquela investigação aquilo não incomoda, mas vai chegar um momento da vida do policial que aquilo vai incomodar. É como se aquilo ficasse guardado, chega um momento em que aquilo vai estourar de algum jeito. Ou ele vai surtar ou ele vai se transformar... Naquele momento especificamente, na minha opinião aquilo não incomoda, não constrange porque ele acha que aquilo é normal na investigação”. (CA6).

cxxi - "Enquanto está dando certo, ele tortura com a mesma naturalidade que ele faz uma intimação ou registra uma ocorrência. O problema é quando dá problema (a vítima denuncia, ou morre...). Aí ele começa a descobrir que estava sozinho nisso. Todos tiram o seu da reta e ele se transforma num monstro da noite para o dia. (...) Como ele vai lidar com isso no futuro eu não tenho a menor idéia. Só sei que os que praticam a tortura hoje não parecem em nada diferente dos que não praticam. São bons pais, carinhosos com as companheiras, religiosos. Creio que alguns não se dão conta da loucura que praticam e pensam que estão fazendo um trabalho norma" (C3).

cxxii - “(...) eu já vi essa frase, não lembro aonde. Antes de mais nada a tortura desumaniza o torturador. Antes mesmo que a vítima, porque a vítima tá ali sendo injustiçada, é vitima de um crime, não é opção dela, enquanto o torturador tá na profissão. Eu acho que a tortura como qualquer outro crime, a pratica reincidente de qualquer crime mexe com o equilíbrio emocional, com a saúde mental das pessoas. Um homem que é habituado no mundo do crime ele é perturbado” (C1).

cxxiii - "Passa, porque dentro de um contexto, não é mais um, é o responsável por todo um setor que vai ser responsável de investigar una gama de crimes, cuja ineficiência vai cair nas costas dele” (C1).

cxxiv - "Claro. Ele é o chefe da equipe. Toda carga recai sobre ele” (C3).

cxxv - "Eu já ouvi comentários de alguém que usa essa prática, que dizia, assaltante de banco, ladrão, só fala se apanhar" (CA6).

cxxvi _ "Um certo reconhecimento de eficiência” (C2).

cxxvii - "Nos casos de que tenho conhecimento, o policial sente prazer em praticar a tortura elou obter os resultados esperados, acreditando ser seu dever e até como forma de proteger a sociedade contra aquele criminoso" (C4).

cxxviii - "Resultado fácil. Resultado implica em promoção, elogio, reconhecimento profissional e social. E, se é desonesto, dinheiro" (C3). 


\section{Dimensiones histórico-sociológicas de la tortura en comisarías de Brasil: el caso Pernambuco}

\footnotetext{
cxxix - "Em primeiro lugar a satisfação pessoal de um doente mental. Obviamente um torturador não é una pessoa que goza de suas faculdades mentais normais. Segundo porque atende também ao interesse de outros enfermos como ele" (CA5).

cxxx - "Sim. Nestes casos a tortura é encarada como um "método” que dá certo" (C4).

cxxxi - "Sim. Somados a ausência de metodologia e a ineficaz repressão” (C2).

cxxxii - "Ninguém se arriscaria a praticar se não tivesse bons resultados. Só os loucos ou sádicos, mas esses são a exceção" (C3).
}

cxxxiii - "Não creio que haja bons resultados nas delegacias. A polícia é muito ineficiente $e$ seguramente a tortura colabora com essa ineficiência. Casos de bons resultados sem uso da tortura é a exceção e não a regra geral. Hoje os policiais que não torturam, não "trabalham" é isso que se ouve e se vê. As atuais gestões tem todo um discurso progressivo, mas não conseguem sensibilizar tampouco controlar o grande efetivo dos policiais. Não tem alternativas" (CA5).

cxxxiv _ "Pode ser. Pode ser" (CA6).

cxxxv - "O resultado é sempre usado como justificativa. Uma forma de diminuir é proporcionar outras formas de investigação e capacitar os policiais para utilizas técnicas modernas de investigação" (C13).

cxxxvi - "Sim. Infelizmente a verdade tem que ser dita. Se não quiser praticar tortura, vá trabalhar em uma especializada tipo, consumidor, estelionato, turista... nas outras em que os crimes são mais graves, tenho certeza que 'o pau canta'”, (C12).

cxxxvii - "Exatamente, porque não se pode deixar de falar que existe uma certa eficiência. Se não tivesse resultado ela naturalmente acabaria por ser um meio obsoleto. Mas por haver eficácia nessa metodologia ela ainda sobrevive” (A1).

cxxxviii - "Eu creio que os bons resultados tem uma grande participação da tortura. Embora não na maioria" (A2).

cxxxix - "Infelizmente sim” (A4).

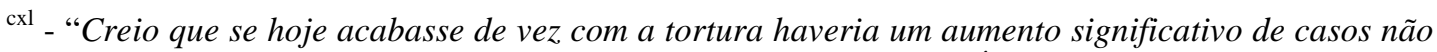
investigados porque muitos não sabem trabalhar de outra forma. É preciso duas ações paralelas: ensinar a investigar e reprimir a tortura” (C3).

cxli - "Na minha instituição sim. Porque inexiste preparo profissional e material para se obter as necessárias provas da materialidade e da autoria” (C4).

cxlii - "Sim. Devido à falta de meios que possibilitem una investigação serena e legal” (C2).

cxliii - "Realmente eu não sei se eu não usasse está prática, se a resolução dos crimes seria inferior, realmente eu não sei...” (CA6). 


\section{Dimensiones histórico-sociológicas de la tortura en comisarías de Brasil: el caso Pernambuco}

\footnotetext{
cxliv - "Não. Porque penso que a apuração de crimes teria um melhor resultado se a polícia fosse dotada de novos, melhores e mais adequados métodos de investigação e os policiais evidentemente soubessem qual é a sua real missão dentro da polícia” (CA5).
}

cxlv - "Logicamente que sim. Digo e repito. Sem métodos modernos, tipo interceptação (difícil de conseguir provas para o pedido) e outros, não tem como se chegar ao autor do crime a não ser torturando nem que seja psicologicamente” (C12).

cxlvi - "Não. Até porque nos últimos anos caiu drasticamente a pratica de tortura e aumentou a apuração de crimes" (C13).

cxlvii - "Na Capital não cairia tanto, mas no interior brabo, no sertão, onde só tem aquele comissário com a mão grossa pra levantar todo serviço, cairia drasticamente. Cairia drasticamente” (A1).

cxlviii - "As carinhas iam ficar vermelhas (índice de apuração de crimes: vermelho, abaixo das metas estabelecidas). Principalmente no interior" (A2).

cxlix - "Sim, porque tem que ter outro método para substituir aquele. Um método inteligente para substituir a tortura" (A4).

cl - "Acredito, eu acho que se torturasse se descobria mais, eu acho. Que na verdade a palavra certa, que era muito usada na época, não é tortura, é tirar serviço. Essa palavra tortura ela nunca é usada. Essa palavra tortura vem da época da ditadura... Então essa palavra tortura é muito usada por direitos humanos. Eles usam muito. Mas policia em si, desde que eu to dentro dela ninguém nunca usou. Torturasse fulano, vamos torturar, sicrano, não. Vamos tirar serviço. Então quem usava muito essa palavra eram os militares, mas a policia investigatória, judicial, judiciária, não nunca usou esse termo" (A3).

cli - "Eu estava a frente de una delegacia (crímenes contra el patrimonio) una vez e alguém veio me dizer que teria que ter algum nível de tortura para ter algum tipo de resultado na delegacia que apurava crimes contra o patrimônio.” (C1).

clii - "No aspecto ambiental estético não vejo, porem no que tange a natureza dos crimes, os contra o patrimônio emocionam a pratica" (C2).

cliii - "Veja, desde que eu entrei (en la policía) que eu escuto comentários de que o praticante, a parte de crimes patrimoniais, o autor de crimes contra o patrimônio, determinados crimes contra o patrimônio, somente se consegue com alguma coisa assim... Então, sei lá, as especializadas que apura ele tipo de crime..." (CA6).

cliv - "Eu tenho a impressão que as especializadas, principalmente de crimes contra o patrimônio. Desde que entrei na polícia eu tenho a impressão que é o lugar mais podre da polícia. Mas realmente não tenho certeza quanto a isso.” (C3).

clv - "Há com certeza. As delegacias direcionadas a crimes de difícil elucidação, narcotráfico, anti sequestros, crimes contra o patrimônio, são delegacias de crime complexo" (A1). 


\section{Dimensiones histórico-sociológicas de la tortura en comisarías de Brasil: el caso Pernambuco}

clvi - “Absolutamente (...) A própria bandidagem tem medo de determinadas delegacias. Você pega o cara e diz: se tu não der a parada tu vai pra roubos e furtos, e tu sabe como é a parada lá. Eu digo isso porque eu já vi.(...) Então tem certas delegacias que elas já tem a sua própria fama.(...) Você tem o GOE, você tem o próprio DENARC, DHPP...” (A2).

clvii _ "Tem. Roubos e furtos, furto de veículos, entorpecente” (A4).

clviii - "Geralmente são as delegacias que agem diretamente com o bandido violento: roubos e furtos, furtos de veículo, GOE. Esses são mais propensos por que trabalham com o crime de maior potencia... Se eles praticam, eu não sei, mas eles tem todo o elemento que provoca o estimulo para que isso aconteça” (A3).

clix - "Sim. Geralmente as delegacias localizadas nos bairros mais pobres, se permitem mais a tortura. Ricos aparecem com advogados e fica difícil investigar, apesar de os policiais não fazerem restrição a torturar rico ou pobre. As delegacias localizadas nos bairros pobres, pelos motivos já expostos e aqueles que praticam crimes violentos, como estupro, homicídio e roubo, além do tráfico para entregar a droga e porte para entregar a arma. Nos de furto, estelionato e naqueles em que não exista violência ou grave ameaça, não se pratica. (...). As delegacias localizadas nos bairros pobres, pelos motivos já expostos e aqueles que praticam crimes violentos, como estupro, homicídio e roubo, além do tráfico para entregar a droga e porte para entregar a arma" (C12).

clx - "Exatamente. A responsabilidade do resultado, a responsabilidade final é do delegado. Então a carga de pressão da própria sociedade, dele para ele mesmo, é muito maior. E para se firmar muitas vezes diante dos próprios policiais" $(\mathrm{Cl})$.

clxi - "Na verdade entendo, face a realidade de condições, que os crimes contra o patrimônio demonstram um certa necessidade de violência no trato com os criminosos, e trazem consigo um certo código de honra, e a pressão pelo resultado imediato nos crimes desta natureza apontam para métodos deste tipo" (C2).

clxii - "Fiz esta pergunta em algumas turmas de policiais, em cursos de formação e em cursos de aperfeiçoamento nos quais tive oportunidade de ministrar aulas. As respostas: obter provas ("tirar serviço”), inclusive confissão; punir o criminoso; perversidade do policial (sadismo); humilhar o criminoso" (C4).

clxiii - "Para mostrar resultados. Nem sempre há provas suficientes, nem meios para encontrá-las. Você não quer ser reconhecidos como incompetente, você quer ser promovido, quer receber as gratificações por resultados...” (C3).

clxiv - "Por sadismo e outras doenças emocionais; por crueldade e deformação do caráter; por permissão e omissão dos órgãos de controle; por total despreparo e desconhecimento da missão a que se propõe; por ausência de métodos científicos e adequados de investigação; Por permissão da sociedade" (CA5).

clxv - "eles com aquela tortura toda fizeram muitos inquéritos? A gente consegue descobrir crime tal e faz um inquérito né, identifica o autor daquele crime, reúne as provas e faz um inquérito. Eles tinham una média de inquéritos que até com menos escrivães e menos delegados, eu tinha menos escrivães e delegados que eles, eu consegui fazer igual ou um pouquinho maior, e a tortura era a regra, a regra 


\section{Dimensiones histórico-sociológicas de la tortura en comisarías de Brasil: el caso Pernambuco}

(para a equipe anterior). Então se a tortura fosse muito eficiente, a regra, sem tortura, teria caído drasticamente a produção de inquérito" (C1).

clxvi - "O desejo de lançar mão desse expediente como una forma de dar resultado é latente. Eu vi pessoas recém nomeadas, vi pessoas que tinham completado 30 anos de idade, vi pessoas que entraram na polícia recentemente e vieram de classe média, sem nenhum problema financeiro a resolver, sem nenhuma pendência, sem una infelicidade né, profunda digamos assim, traumas, lançar mão desse expediente por tê-lo como eficiente. Sempre há essa tentação, entre aspas, de lançar mão porque dá resultado, e as pessoas querem dar resultado" (C1).

clxvii - "Se não houver una punição forte, sempre haverá tortura porque é muito mais fácil que pedir autorização para fazer una escuta, mandados, reunir provas, convencer a alguém a ser testemunha, etc” $(C 3)$.

clxviii - "Realmente eu não sei se eu não usasse está prática, se a resolução dos crimes seria inferior, realmente eu não sei...” (CA6).

clxix - "É eficiente. Moralmente inaceitável, mas na maioria dos casos eficiente" (C3).

clxx _ "Depende da ótica” (C2).

clxxi - "Sim, em termos de produção de inquéritos" (C4).

clxxii - "Eu acho que sim. Eu acho que sim. É como um comportamento assim, aquele negócio, enquanto não der nada, não vier à tona é como se fosse absolvido em nome do resultado” (C1).

clxxiii - "Com certeza preferem aqueles que torturam e trazem resultados, mas que não trazem problemas legais” (C2).

clxxiv - "Creio que eles preferem não saber como os resultados apareceram, desde que apareçam. Se os resultados são bons eles ganham os louros porque foram bons administradores. Se aparece alguma historia de tortura, como eles não sabiam e não participaram, ainda poderão dizer que os culpados serão severamente punidos, etc. Ou seja, outra razão porque creio que se importam só com os resultados é que jamais vi uma campanha ou pronunciamento de qualquer chefe de polícia contra a tortura”. (C3).

clxxv _ "Os chefes que também são maus, preferem os maus policiais. Se for um bom chefe e preparado, dificilmente vai preferir um mau policial” (CA5).

clxxvi - "A primeira opção, logicamente. Mas isso é perigoso, pois muitos chefes não vão querer se comprometer, caso se descubra” (C12).

clxxvii - "Creio que no passado eram os que torturavam e traziam resultado, mas essa realidade vem mudando" (C13).

clxxviii - "Depende do tipo de trabalho. O delegado de uma cidade tranquila ele não quer problema com tortura, mas o delegado de uma circunscrição pesada ele quer o torturador” (A1). 


\section{Dimensiones histórico-sociológicas de la tortura en comisarías de Brasil: el caso Pernambuco}

clxxix _ "Na maioria das vezes eu acho que sim. Porque a pessoa do delegado vive do resultado que produz. Você tá na delegacia do Espinheiro e você produz, tá todo mundo contente com você. Se você não produz, vão te mandar pra Cabrobó e lhe esconder lá. Um delegado ele não quer isso pra ele, ele quer se destacar. Então se ele tá botando a mão nisso, mas tá tendo resultado, isso foi com a maioria que eu trabalhei, então a equipe dele tá boa. A equipe tá dando o resultado que ele quer. Os líderes da Polícia Civil estão mais preocupados com números e com as carinhas (índice de avaliação de resultados) que com o que se anda fazendo nas ruas” (A2).

clxxx _ "Isso vai depender do chefe" (A4).

clxxxi - "Infelizmente eram violentos" (A4).

clxxxii - "Conheci vários casos de delegados que eram notórios torturadores e ocuparam postos mais significativos dentro da estrutura policial. Tanto civil quanto militar” (C1).

clxxxiii - "Sem dúvida!” (C3).

clxxiv _ "Evidentemente. Isso já ocorreu por diversas vezes com outros policiais” (CA5).

clxxx _ "Em minha instituição, sim. Inclusive conheço casos desta natureza” (C4).

clxxxvi - "Lógico que sim, pois ninguém iria dizer que tudo foi feito por meio de tortura" (C12).

clxxxvii - "Creio que não” (C13).

clxxxviii _ "Não. Existem vários fatores, o que é necessário fazer e é dar resultados” (C2).

clxxxix - "Se essa equipe, com tortura ou não, conseguir os resultados pretendidos pelos superiores, vai ascender. O que importa são os resultados" (Al).

cxc - "Eu creio que praticando a tortura você chega ao resultado, então se esse resultado lhe leva para esse caminho, então eu não poderia negar essa realidade" (A2).

cxci - "Eu acho que tem isso. Não é pela prática da tortura. É tipo assim, eles são conhecidos como policiais que eventualmente eles fazem determinados, né, eles usam dessas práticas, mas assim, isso não impede que eles ascendam, que eles sejam promovidos na classe de delegados e também que eles assumam cargos de titularidades de delegacias que são importantes" (CA6).

cxcii - "Vários" (C3).

cxciii - "Sim. Policial operacional de resultado" (C2).

cxciv - "Conheço alguns que são e outros que, com as mesmas práticas, não são. Se ele consegue resultados (concluir inquérito com autoria), ele é promovido, reconhecido, elogiado" $(\mathrm{C} 4)$.

cxcv - "Seguramente. Não apenas um, mas um rol inteiro de policiais. O bom torturador era também idolatrado e poderoso além de ser temido. Era reconhecido como um homem forte e muitas vezes líder” (CA5). 


\section{Dimensiones histórico-sociológicas de la tortura en comisarías de Brasil: el caso Pernambuco}

cxcvi - "Sim, muitos. Os resultados mostraram" (C12).

cxcvii - "Conheço. Na época em que isso ocorreu a cúpula da Polícia valorizava os resultados, sejam eles obtidos de que jeito fossem" (C13).

cxcviii - "Conheço” (Al).

cxcix - "Não. Assim, explicitamente conhecido não. Não foi promovido por isso. Agora o sistema não reconhece isso. $O$ sistema promove o delegado que chegou ao resultado. Como ele chegou ao resultado, não interessa..." (A2).

cc - "Conheço vários. Rapidamente promovido. Eu passei 18 anos para ser promovido e conheço colegas que foram promovidos com 6 anos, graças a esse tipo de trabalho” (A4).

cci - "Tem... Tem, muitos" (A3).

ccii - "Acredito que pelos bons resultados. Fica difícil de dizer que todo resultado foi utilizado isso aí porque a gente não conhece o dia a dia, a prática, seria impossível dizer isso. Mas se ascende não é porque usou essa prática, mas porque demonstrou um bom trabalho por onde passou” (CA6).

cciii - "Pelos bons resultados. Agora mesmo há una política de premiação de acordo com os resultados. Há inclusive encontros com o Governador onde você vai explicar seu sucesso ou fracasso. Duvido que o governador ou qualquer chefe antes de premiar algum delegado pelo êxito de seu trabalho, vá investigar se ele anda torturando. O governador, o chefe de polícia, o diretor, dessa ou de qualquer outra polícia está preocupado com os números. Pois disso depende sua permanência na cadeira preta. Com tortura, eles só vão se preocupar se estourar algum escândalo na imprensa. Aí eles vão dizer que não toleram isso, que vão apurar, bla, bla, bla” (C3).

cciv - "Existe, que às vezes inclusive quando um policial é dado a ele a missão de investigar um crime de repercussão (...). Então ele vai usar ele método que ele já usava para ter um resultado rápido porque ele sabe que vai ser elogiado pelo governador, pela sociedade, vai ter a foto no jornal. E muitas vezes ele vai ter una carreira meteórica na polícia e pode ter até lá fora como ser político por exemplo” (...). (C1).

ccv - "Sim. Tendo em vista o resultado" (C2).

ccvi _ "Sim. Bons resultados geram elogios e promoções" (C3).

ccvii - "Sim. Isto aconteceu quando o gestor de polícia era, sabidamente, um policial adepto da prática da tortura" (C4).

ccviii - "Não só é possível como ainda é utilizada infelizmente. Não creio que atualmente seja hoje o primeiro critério, mas ainda conta com um peso valioso para o modelo de policial que ainda impera nas nossas sociedades" (CA5). 


\section{Dimensiones histórico-sociológicas de la tortura en comisarías de Brasil: el caso Pernambuco}

ccix - "Certamente. A própria sociedade comunga com o pensamento de que o criminoso deve apanhar. Já me ocorreu de uma senhora que foi assaltada, ao descobrir que seu neto estava envolvido no crime me pedir para espancar ele" (C13).

ccx - "Acredito que as pessoas ascendem profissionalmente pelo trabalho prestado, mas ninguém vai analisar se foi conseguido por meios ilegais" (C12).

ccxi - "Exatamente" (A4).

ccxii - "Conseguem confiança do chefe que muitas vezes não admitem tortura, mas gostam do resultado.(...) Sim e muito. Na cidade da área metropolitana onde trabalhei, a utilização da tortura deu um resultado positivo na diminuição da violência. $O$ número de homicídios na área caiu mais da metade, em média a cada mês (...) Creio que nenhum policial sente prazer em fazê-lo. Faz para agradar a chefia e dizer que conseguiu investigar e prender, porém, masoquismo eu ainda não consegui visualizar" (C12).

ccxiii _ "Projeção profissional (...) Alguns resultados acabam ocorrendo, mas sempre se tem riscos de cometimento de injustiças e fragilidade da autoridade quando se sujeita a praticar crimes para solucionar outros" (C13).

ccxiv - "A sensação do dever cumprido. A satisfação de chegar com o resultado para o chefe. Talvez. queira ser mais policial, mais homem que o outro" (A4).

ccxv - "O agente ele quer ter uma relação de reconhecimento por parte de seu delegado. Ele quer que o delegado olhe pra ele e diga que ele tem um policial que me dá o resultado. "Eu tenho um policial competente; eu tenho um policial que eu confio, que eu vou dar determinado caso pra ele e ele vai resolver isso pra mim". Então o agente ele quer ter essa relação com o delegado. Ele quer que o delegado goste dele, que o delegado se sinta bem trabalhando com ele... Então, na maioria dos policiais civis, inclusive eu, quer fazer o seu nome na instituição, quer ser reconhecido. Cada um usa os seus meios pra fazer isso. Uns usam a tortura, outros usam meios burocráticos. Você quer conseguir seu espaço na polícia civil...” (A2).

ccxvi - "Credibilidade, regalias, promoções, respeito dos colegas e do chefe" (A3).

ccxii - "Agora eu acho que a tortura ela fica mais impregnada em toda rede policial quando tem o componente da corrupção porque o cara fica obcecado por ter um resultado não só para apresentar ao chefe, mas para ter dinheiro no bolso que ele tem que ter pressa. (...) Só que tem um componente que a gente não pensa enquanto fala de tortura. Acho que também pensa más não fala. Onde existe tortura como pratica rotineira existe um ganho de dinheiro para aquelas pessoas que participam ali. $O$ cara da delegacia, existe muita tortura principalmente nas delegacias de crimes contra o patrimônio. Nestas delegacias de crimes contra o patrimônio onde a tortura é uma coisa permanente, rotineira, há um ganho de dinheiro, seja da vítima, seja através da extorsão do próprio bandido" (C1).

ccxviii - "Grande relação. Quem tortura sistematicamente não tem freios para a corrupção, ou seja, toma dinheiro" (C2).

ccxix - "Sim. Soube de alguns casos dessa relação, quando a intenção era "livrar” o corruptor” (C4). 


\section{Dimensiones histórico-sociológicas de la tortura en comisarías de Brasil: el caso Pernambuco}

ccxx _ "Estrita e intima relação" (CA5).

ccxi - "Na minha cabeça tortura e corrupção está mais associado com as especializadas. Já trabalhei em homicídios e não vi casos de tortura por lá. Talvez nas especializadas em crimes contra o patrimônio" (C3).

ccxii - "Existe uma certa relação porque o próprio bandido não quer sofrer. Se você vai trabalhar determinado bandido e ele sabe que está nas suas mãos ele pode te dar determinada vantagem. Eu sou totalmente contra, mas eu já vi, quer dizer, já ouvi... Principalmente em delegacias como o Denarc, onde o bandido já tem uma quantia pronta para o policial... Prefere dar essa vantagem grande, que apanhar e ser preso...” (A2).

ccxxiii - "Andava junto porque pra você conseguir alguma coisa, o cara com medo de ser torturado, facilitava pra você. Pra o nego não apanhar, arrumava. Geralmente, do chefe ao último peão. Do primeiro escalão ao ultimo. Era muito mais que hoje”. (A3)

ccxiv - "Tem, tem uma relação. A tortura vem muitas vezes para a pessoa descobrir um benefício para eles. Muitos policiais vão por essa linha” (A4).

ccxxv - “(...) Você pratica uma tortura para castigar o autor de um crime contra uma pessoa rica que com certeza vai, com certeza, vai te dar dinheiro, você pratica a tortura para receber informação de carros que foi roubado para que você devolva ao proprietário e isso vai te dar dinheiro... Eu acho que muito da tortura está ligado à corrupção pela necessidade que você tem da contrapartida da vantangem ilícita que você vai tem” (C14).

ccxxvi - "Normalmente, policiais torturadores acabam se corrompendo. De tanto viver a margem da lei eles acreditam que precisam ser recompensados com algúm ganho extra” (C13).

ccxvii - "Não. Tenho policiais que torturam e são honestos. Certeza” (C12).

ccxxviii - "Quando fui aluno da Academia não tocaram no assunto de tortura, era como se ele não existisse, e naquela época existia muito mais do que hoje” (Cl).

ccxxix - "Não. Os conteúdos jamais abordaram a tema tortura. Esse era um assunto tabu. Eu sabia que policiais torturavam, mas na Academia era proibido falar sobre o tema” (CA5).

ccxx - "Tal tema não fez parte do conteúdo do curso de formação. Na verdade, havia um certo receio de tocar neste ponto, seja por parte dos alunos quanto dos professores. Alguns professores fizeram referência ao tema, mas de forma vaga” (C4).

ccxxxi - "Não lembro. Faz muito tempo. Não lembro se esse tema foi discutido" (CA6).

ccxxii - "Não consigo lembrar que esse tema tenha sido abordado durante o curso de formação. Lembro que havia um excesso de matéria jurídica e que os alunos estavam mais preparados que os professores, pois os alunos vinha estudando para fazer os concursos que aparecessem $e$ os professores eram delegados que estavam bem desatualizados" (C3). 


\section{Dimensiones histórico-sociológicas de la tortura en comisarías de Brasil: el caso Pernambuco}

ccxxiii - "Não houve na academia esse tipo de informações, pois a minha academia durou apenas 45 dias” (C12)

ccxxiv - "Eu tive a oportunidade de fazer duas academias, uma de policia militar e uma de policia civil, essa ultima agora. Em ambas esse assunto foi bastante abordado. A declaração dos direitos humanos era lida e relida, diversas vezes. Mas sempre nos foi posto de forma dogmática. Dizia, olhe, não pode torturar. Tortura é crime. Sempre de forma mecânica. Nunca foi procurado uma abordagem do por quê, do como, pra quê. Sobre esse assunto. Era até meio místico, era uma cadeira pequena onde a função única do instrutor era passar aos alunos, vocês serão policiais e não podem torturar. Existe essa declaração dos direitos humanos, que eu vou ler pra vocês, e existe a lei dos crimes hediondos e caso vocês façam, vocês serão demitidos. E até mesmo presos. Só isso. De forma bem superficial” (A1).

ccxxv - "Esse tema, por ser um tema atual, foi muito abordado durante a Academia. Sempre frisando bem que o policial civil tenha plena consciência dos direitos humanos... As aulas eram mais formais, passavam parte da legislação específica dos direitos humanos, de tortura. Mas não trabalhavam com casos reais, nem tinha nenhuma discussão ética. Eram mais positivistas” (A2).

ccxxvi - "No meu tempo, foi 82 pra 83, era interessante porque tinha um professor que pregava a violência, ele dizia que o policial tinha que ser bruto. Logo depois saía esse professor e entrava uma professora dizendo que não era pra ser assim, tinha que ser tratado direito... Ficava esse jogo: o professor dizendo não dê ouvido a professora que ela quer resolver direitinho, botar o bandido no braço... Bandido é no cacete! A professora dizia não faça isso não que vocês vão ser tudo expulsos, vão responder processo. Então ficava esse dilema, saia um, entrava outro. E não dava diferença de um dia não. Saía um entrava o outro. Essa professora dava aula de sociologia e o professor, de policiamento do interior. E o professor era brabo que era danado, dizia, 'favela é pra entrar derrubando, quebrando, arrastando. Na área nobre não, se fizer isso vai ser demitido logo, logo se trabalhar em Boa Viagem, Espinheiro'. E outra também é a cultura do povo, você não pode entrar tão delicadamente no Coque, dando bom dia, boa tarde... porque um ou outro entende, mas a maioria lá não entende não. Infelizmente essa é a verdade. Na favela mesmo, eles só entendem na grossura. Se você falar educado ele acha que tá por cima, que a polícia tá com medo deles. Que ele tá levando vantagem sobre a polícia. Aí infelizmente é assim a vida do policial trabalhando na favela” (A4).

ccxxvii - "Vários, vários, principalmente aqueles que tinham uma formação militar. Nessa ultima Academia que 60\% já foi PM. Então era uníssono até. Quando o instrutor falava já era repelido de imediato pelos alunos que tinham experiência de rua. 'É por que tu não tá na rua pra saber como funciona'. Então ficava apenas aquela troca de farpas e nunca se chegava a um denominador comum. Eu achava importante dizer eu sou contra a tortura, eu sou contra toda e qualquer tipo de tortura, mas é necessário se abordar de forma mais profunda esse tema porque existe os prós e contras. As arestas a serem moldadas" (A1).

ccxxxiii - "A opinião da turma era bem diferenciada. Alguns eram a favor, dependendo do caso. Outros eram absolutamente contra” (A2).

ccxxxix - "Não” (CA6). 


\section{Dimensiones histórico-sociológicas de la tortura en comisarías de Brasil: el caso Pernambuco}

${ }^{c c x l}$ - "Não. em nada tais conteúdos ajudaram a formar um conceito, una atitude relativa à tortura" (C4).

ccxli - "Não. Na verdade, os conteúdos se mostraram insuficientes para a teórica prática de investigação dentro do Estado democrático de direito. Havia uma preocupação apenas formal em dizer que a tortura era algo ilegal com leis de repressão na atualidade" (C2).

ccxlii - "Não pelos conteúdos, mas sim com o ambiente extra sala de aula. Eu era totalmente contra antes e comecei a flexibilizar minha opinião durante a Academia” (C3).

ccxliii - "Não, pelo contrário, os professores valorizavam o policiai operacional e o conceito deste era daquele que obtinha informações mesmo com tortura” (C13).

ccxliv - “Não. Eu tinha uma visão péssima sobre a tortura” (C12).

ccxlv - “As aulas davam um norte... é porque pós Academia também nos é passado... Isso é complicado... Administrar informações desse jeito porque também nos era passado em outras cadeiras que dizia: Você agora tem poder de polícia. Aí os alunos, E o que seria esse poder de polícia? $O$ instrutor de forma metódica e didática dizia. 'É o poder que o estado lhe dá para em nome dele, Estado e do bem comum, tolher o bem e o direito de um indivíduo'. Então veja a forma como essa informação foi assimilada por vários mundos. Porque cada aluno é um mundo. Cada aluno uma realidade. E essa informação chegou a todos os alunos, de que você agora tá investido do poder de polícia. Então estou eu agora, aluno, sabendo que o Estado me deu esse poder, e como usá-lo? Maquiavel dizia, os fins justificam os meios (...)” (Al).

ccxlvi - "Não. A Academia serviu mais para mostrar a parte positivista da coisa... Ela foi válida porque os instrutores, apesar de valorizar a parte mais legal da coisa, mostravam o risco que havia de praticar a tortura, prejudicar a carreira ou a imagem da corporação” (A2).

ccxlvii - "Antes de entrar eu era contra... Às vezes eu batia de frente com o professor e dizia não precisa fazer isso não... Eu acho que com conversa agente consegue muita coisa... Porque se o informante não for bom, o bandido pode morrer apanhando e não vai dizer nada... Eu sempre fui contra a tortura... Aí alguns colegas diziam, ah rapaz, o policial tem que ser bruto, truculento e "astabiriado", um nome desses. O policial tem ser feio, grande e forte, era aquela imagem de antigamente. E quando fui trabalhar realmente tinha aqueles comissários que davam grito e batiam nas pessoas e eu dizia que não precisava daquilo e eles diziam, que nada você novinho aqui fazendo faculdade quer mudar a polícia. tem que ser grossa tem que bater... Mas né fogo, vou sair disso aqui. E meu pai, que também era policia, dizia, tenha paciência meu filho, estude e passe em outro concurso aí você sai daqui..." (A4).

ccxlviii - "Perfeito. Perfeito, perfeito, porque talvez sem essa experiência, mesmo uma pessoa que não passou pela academia, mas sabe que torturar é crime. Sabe que bater... Todo e qualquer crime de tortura é errado tanto do ponto de vista legal ou ético. Mas essa dimensão de proteger o bem, a historinha do super homem... é complicado...” (Al).

ccxlix - "Sim” (C13). 


\section{Dimensiones histórico-sociológicas de la tortura en comisarías de Brasil: el caso Pernambuco}

${ }^{c l}$ - "Na saída da academia e no início da carreira eu não tolerava a tortura. Minha intenção não era
seguir a carreira policial no inicio e não me destacava trabalhando na área, pois não permitia que
policiais utilizassem tais métodos e isso gerava descontentamento por meio dos subordinados que
diziam nada poder fazer para investigar um crime diante das dificuldades e falta de estrutura. (C12).

ccli - "Era tratado como um mal necessário. Tem gente que dizia: “em certos casos não tem opção” (C1).

cclii - "Sem interesse. As pessoas tinham medo de comentar" (CA5).

ccliii - "Com normalidade, como algo necessário na prática, una vez que a prática legalista se mostraria ineficiente na prática” (C2).

ccliv - "Muitas vezes eu ouvia brincadeiras sobre torturas e outras vezes eu ouvia relatos de casos que eram solucionados com tortura. Mas não havia nenhum pudor sobre isso. Era como se fosse algo normal, banal. Pelo contrário, se havia algum pudor era o de demonstrar que éramos contrários à tortura. Era como se isso parecesse que não levávamos jeito para ser policial. Os policiais mais antigos olhavam para nós, jovens policiais como se faltasse alguma coisa, não servíssemos para o trabalho porque éramos muito educados... Sei lá, muito legalistas... Era como se não fôssemos policiais... Se falássemos alguma coisa contra a tortura aí que pareceríamos extraterrestres” (C3).

cclv - "Na informalidade, conversávamos sobre o tema fazendo referência a algum caso de crime que teve grande repercussão na mídia e, nessas oportunidades, alguns alunos que já faziam parte dos quadros da polícia civil - agentes ou escrivães - diziam que naquelas investigações o "método" utilizado foi o da tortura. Isto era visto com naturalidade por aqueles alunos" (C4).

cclvi - "As experiências repassadas sempre envolviam torturas onde o policial era bem sucedido em realizá-las e apenas os preguiçosos é que se contentavam com o depoimento sem tortura” (C13).

cclvii - "Fora da sala de aula o tema era tratado com críticas em relação àqueles alunos que não tinham vocação para ser policiais e estavam ali apenas para ter um emprego, todavia, os que se diziam vocacionados sempre tratavam a tortura como necessária” (C12).

cclviii - "É um assunto que para jovens que ingressaram soa até meio pejorativo. Muitos diziam o que é que vocês acham da tortura? 'Puta que pariu tem que torturar mesmo... bandido bom... tem que levar cacete, porque só com cacete ele abre...' Então assim, como havia essa mecanicidade por parte do instrutor, havia essa leviandade por parte do aluno. 'Não, é cacete mesmo, porque é cacete que resolve... ¿'Tá entendendo? Nunca houve uma via de troca de experiências, nem seria tanto de troca de experiências, porque experiência não tinha. Mas, um canal mais aberto, um 'por que você acha que o bandido tem que apanhar?'. Nunca isso foi perguntado. Apenas era repetido que sendo bandido ou não, não pode apanhar" (Al).

cclix - "São determinados grupos que se formam na própria turma, como é a tendência é a de você se aproximar do grupo que você mais se afeiçoa... E aí havia grupos que vinham da PM e eram favoráveis ao uso da tortura... E aí havia os mais conservadores, que vieram de cursos de Psicologia que era um pessoal que nunca teve experiência policial de rua na vida... Então a opinião geral que prevalecia dentro do meu grupo era a de que dependia da necessidade do serviço” (A2). 


\section{Dimensiones histórico-sociológicas de la tortura en comisarías de Brasil: el caso Pernambuco}

cclx - "O conteúdo fora da Academia era influenciado pelos que já eram policiais e diziam que lá fora, sem cacete, a turma não respeitava a polícia e era pra dá cacete mesmo, a polícia era cacete mesmo, em 86" (A3).

cclxi - "Sim, muita gente dizia que deveria ter disciplinas como tortura 1, tortura 2...” (C12).

cclxii - "Sim, a tortura era encarada com uma coisa normal, desde que existisse uma investigação policial” (C13).

cclxiii - "Ah, com certeza. Por parte dos alunos sempre soavam de forma pejorativa. E eu lembro que quando eu estava na Academia foi quando surgiu o lendário 'Tropa de Elite'. Então, depois desse filme, dar aula de direitos humanos ficou mais difícil. Ficou bem mais difícil. Sempre o aluno tinha uma resposta que justificava uma possível tortura. E demais casos que eram apresentados por alunos de forma sensacionalista: oh, fulano levou um cacete e abriu...” (A1).

cclxiv - "Ah, com certeza. Por parte dos alunos sempre soavam de forma pejorativa. E eu lembro que quando eu estava na Academia foi quando surgiu o lendário 'Tropa de Elite'. Então, depois desse filme, dar aula de direitos humanos ficou mais difícil. Ficou bem mais difícil. Sempre o aluno tinha uma resposta que justificava uma possível tortura. E demais casos que eram apresentados por alunos de forma sensacionalista: oh, fulano levou um cacete e abriu...” (A1).

cclxv - "Não. Muito superficial. Eu fiz 45 dias de curso" (C1).

cclxvi - "O curso era uma piada. Em 45 dias de curso eu dei cinco disparos com um revólver velho e nunca tive uma aula que ensinasse a investigar. Aprendi tudo que sei no dia a dia” (C3).

cclxvii - "Não. Eu pelo menos, na minha pratica de Academia, não me ensinou nada não. Eu aprendi no dia a dia. E pelo que conheço de algumas outras capacitações em algumas outras épocas de Academia, acho que também não teve isso não" (CA6).

cclxviii - "Não. Os conteúdos não tinham o direcionamento prático, sem estudos de caso e exercícios práticos de busca de informações e relacionamento com provas técnicas” (C2).

cclxix - "Não. O que se repassava é que o melhor investigador era aquele que tivesse a melhor rede de informantes" (C13).

cclxx - "Embora este seja, a meu ver, o principal aprendizado que o policial civil deveria ter, ficou longe das minhas expectativas. Os principais motivos desta falha no processo de aprendizagem foram: despreparo dos professores; pouca carga horária dispensada à disciplina; falta de una visão mais contemporânea dos métodos de investigação, incluindo técnicas científicas referente à coleta de provas" (C4).

cclxxi - "Não sei exatamente se era bom ou mal, mas eram os mesmos métodos utilizados há mais de trinta anos. A Academia se preocupava mais em que os alunos aprendessem a copiar os procedimentos do que propriamente a buscar uma verdade científica para suas investigações, até mesmo que esse era um papel reservado aos Delegados de Policia e não aos Agentes” (CA5). 


\section{Dimensiones histórico-sociológicas de la tortura en comisarías de Brasil: el caso Pernambuco}

cclxii - "Na academia, como dito, não houve nenhum preparo para a vida policial, uma vez que ela durou apenas 45 dias” (C12).

cclxxiii - "A formação é boa. Eu vejo como uma formação de qualidade. Hoje a polícia dispõe de mecanismo e dispositivos que auxilia a esse processo investigativo. No entanto, eu creio por experiência que a vivencia é que te faz um policial bom ou mal. A Academia não influencia em nada nesse aspecto" (Al).

cclxxiv - "Foi satisfatório teoricamente... Embora faltou uma parte pratica. Não houve uma parte prática, de casos práticos, de uma investigação policial... Houve uma parte teórica muito rica, mas faltou pratica” (A2).

cclxxv - "Era muito bom. Se for seguir realmente o que manda a pessoa investiga muita coisa... É que hoje em dia ninguém tem paciência, nem tempo” (A4).

cclxxvi - "De forma alguma” (A1).

cclxviii - "Os policiais mais antigos tem uma frase que é típica, tanto na policia militar como na civil... eles tendem a lhe chamar de novinhos, que são os policiais recém formados, então quando você vai pra pratica eles costumam dizer: novinho esqueça tudo o que você aprendeu na Academia, porque aqui na pratica a policia é outra... O que você aprendeu na Academia é teoria, foi pura formalidade porque muito pouco você vai aplicar. Infelizmente em boa parte dos casos eles até que estavam certos" (A2).

cclxxviii - "E muito. Aprendi que a bandidagem só respeita a polícia com tratamento não condizente com os direitos humanos. Aprendi, quando comecei realmente a trabalhar na polícia que apenas com métodos não convencionais que contrariam os direitos humanos é que se conseguia "tirar" serviço, como o local onde estava escondida arma, droga...caso contrário, o trabalho não tinha sucesso. Mas no meu caso sempre observava os limites para os policiais não exagerarem” (C12).

cclxix - "Sim, mas a partir de experiências pessoais e muita reflexão” (C13).

cclxxx - "Não. Não é suficiente não. A gente tem que juntar as duas coisas. As informações teóricas e a parte prática. Até por que às vezes você não conhece a técnica você podia utilizar melhor e está deixando de tirar mais frutos do que poderia tirar porque não conhece” (CA6).

cclxxi - "Não. Você chega numa delegacia onde você é o chefe máximo e não sabe para onde vai nada. Por sorte há funcionários que já estão lá e vão ensinando. Mas também podem ser muito sacanas ao perceber sua inexperiência. Às vezes eles se aproveitam para fazer o que não podem e às vezes se aproveitam para se divertirem às suas custas. Até chegar o dia que você já se sente seguro muita merda já pode ter rolado por sua falta de preparo" (C3).

cclxxii - "Não. Como a deficiência na formação é um fato antigo, encontrei policiais que pouco conheciam a respeito de métodos de investigação. A chamada polícia científica não dispunha de aparelhagem adequada. Foi necessário investir em leituras e cursos específicos" (C4).

cclxxiii - "Não, pois há obstáculos que só o conhecimento sistemático e científico é capaz de trazer resultados práticos" (C2). 


\section{Dimensiones histórico-sociológicas de la tortura en comisarías de Brasil: el caso Pernambuco}

cclxxiv - "Dentro do universo reservado ao papel da própria polícia sim, até mesmo porque em muitos casos os novos agentes eram obrigados "desprezar" o conhecimento formal, teórico y aprender na realidade cotidiana com os outros companheiros. Nisso claro, não havia nenhuma participação da Academia de Policia ou outra unidade de recursos humanos” (CA5).

cclxxx - "Sim. Há métodos de investigação que permitem coletar e trabalhar provas de forma sistematizada. (...) Investir na formação do policial em métodos de investigação; aprimorar os mecanismos de responsabilização aos que praticam este crime; equipar as unidades policiais e a chamada polícia científica” (C4).

cclxxvi - "Sim. A meticulosa coleta de vestígios em local de crime, com relacionamento intimo com os profissionais de polícia científica envoltos na investigação, numa troca constante e obstinada de informações focadas. Ainda estudo e prática de relacionamento com a natureza humana, tendo em vista a inafastável necessidade de coleta de prova oral, obtida de testemunhas, vítimas, suspeitos e informantes" (C2).

cclxxxii - "Primeiro, ensinar a investigar. Segundo, dar os meios necessários para que possa ocorrer una investigação. Hoje há muitos mais casos que pessoal e meios para investigá-los. Quando há pressão e tu não consegues dar conta da demanda, pode ser muito tentador recorrer à tortura" $(C 3)$.

cclxxxviii - "Eu creio que a Academia, já na formação, deveria deixar bem claro que a tortura não é una coisa bem vinda. Mas eu acho que ainda há professores que deixam nas entrelinhas, deixam transparecer, que é una coisa que deve ser cultivada. Então deveria ser proibido que quem é adepto desse tipo de postura possa ensinar, por exemplo. Mas isso é muito difícil. Primeiro, como é una prática muito corrente tinha que ter una cadeira com o principal assunto daquela cadeira ser a tortura, não sei exatamente qual, pensei nisso agora e não sei qual exatamente seria possível. Interrogatório. Dentro da cadeira de interrogatório teria que ter bem claro que esse tema deveria ser evidenciado. Hoje nós temos a cadeira de direitos humanos na Academia e eu acho que até a cadeira de direitos humanos fala pouco do combate a tortura. E eu acho que tem que começar na Academia que eu acho que é o obvio. E a polícia tem que adotar padrões, para, por exemplo, constar em todos os depoimentos do indiciado, perguntas sobre a tortura. E crimes, teriam que pegar, eu acho que seria eficiente a corregedoria pegar aleatoriamente flagrantes, inquéritos policiais de homicídio e crimes contra o patrimônio, principalmente desses dois, e chamar essas pessoas, chamar as vítimas, chamar os indiciados, fazer una investigação sem precisar ser provocado. Se eu sei que com aquele meu inquérito a corregedoria pode pegar e checá-lo, vê contradições... Porque muitas vezes contradições levam a crer que houve tortura. Então os inquéritos não são lidos pela corregedoria como forma de prevenir e detectar que houve tortura naquele inquérito. Entrevistas com os presos. (...) Então todo mundo que passou por delegacia deveria ser entrevistada por um órgão, seja secretaria de saúde, de educação, seja La qual for, para detectar. Eu acho que se o delegado sabe que aquele preso vai ser ouvido na corregedoria mesmo sem ele denunciar, mesmo a perícia não acusando o crime de tortura, ele pensaria duas vezes. Eu acho que por amostragem deveria ser. As delegacias terem câmeras, você não pode ter salas onde as pessoas se fechem sem ser vistas, sem saber o que estão fazendo, bem iluminadas (...). A estrutura física, como as delegacias estão construídas, ajudam a diminuir a tortura ou ajuda a aumentar. Capacitações de quatro e quatro anos. Seminários anuais. Eu acho que as associações de delegados do Brasil, inclusive de policiais militares, jamais vão colocar em pauta a tortura, mesmo delegados que pensam contra a tortura não colocam isso em pauta para não desagradar" (C1). 


\section{Dimensiones histórico-sociológicas de la tortura en comisarías de Brasil: el caso Pernambuco}

cclxxxix - "Possibilitar aos policiais outras técnicas e formas lícitas de obterem resultado $e$ conscientizar que a tortura os torna criminosos também. (...) Creio que a luta contra a tortura não será resolvida em apenas uma geração. Ainda somos uma geração que não esqueçeu a ditadura militar como forma de governo, ou seja, estamos acostumados com o Estado repressor, unipotente. Certamente a profissionalização da policia e a constante renovação dos quadros policiais contribuirá para o afastamento da tortura. Mas como a atividade policial consiste no uso da força sempre haverá necessidade de acompanhamento para que a tortura não seja utilizada" (C13).

ccxc - "A polícia deve ter um discurso não só de combate a tortura, mas de construção de una nova missão para a polícia e de um novo papel par ao policial. Isso creio que ainda estamos há anos luz, porque isso só poderia acontecer com a efetiva participação da sociedade. E a sociedade ainda esta interessada em manter una tolerância para os atos corruptos e conseqüentemente com a tortura. Creio que trabalhos dessa natureza podem vir a colaborar pelo menos para se ter um diagnostico um pouco realista sobre o tema nas instituições” (CA5).

ccxci - "Apenas métodos técnicos. Existe também o poder de convencimento. Muitas vezes ameaças e palavras fazem as testemunhas e os próprios investigados "abrirem”, facilitando as investigações. Os riscos da tortura são grandes para os policiais, no entanto, aqueles que praticaram torturas, digamos que leves, sempre se destacavam em relação àqueles que não torturavam”(C12).

ccxcii - "Creio que a valorização da interceptação telefônica como meio de investigação é muito importante nesse sentido. Ela fornece tantos elementos de convicção que não se precisa mais de confissão alguma, o que constitui um importante instrumento para mudar a cultura de tortura. Mas a interceptação não é o único meio. É preciso estimular outras formas de investigação que subsidiem e complementem o inquérito, tais como a vigilância, a quebra de sigilos, a busca de outras informações contidas em bancos de dados, etc" (C13).

ccxciii - "É dada muita ênfase. Tanto que quem não tortura não se preocupa com quem não confessa. É até melhor quando não confessa que é um dos indicativos de que não foi torturado. E se você consegue provar o crime sem a confissão dele você vai ter muito mais credibilidade. É interessante porque, muitas vezes, quando começa um interrogatório que você tem provas mínimas contra aquela pessoa, ele não confessando, você não tem nenhum estresse” $(\mathrm{Cl})$.

ccxiv - "Sim. Creio que isso é o mais interessante que pode acontecer. O sonho de todo investigador. E aí já podemos passar para o próximo caso. Quando você tem cem casos para dar conta, não sobra espaço para romantismo nenhum. Se há una confissão é um caso a menos” (C3).

ccxcv - “(...) quando trabalhei nas delegacias do interior, todo o trabalho é feito na base da confissão porque não tem os meios técnicos, então você não tem as provas materiais. Então no interior, a confissão é imprescindivel. Agora na Capital como você tem os recursos, mas ainda não são utilizados de forma satisfatória, então acho que a confissão para a ser um tema acessório. Mas nas delegacias do interior a confissão é praticamente $90 \%$ do inquérito” (A2).

ccxcvi - "Não. A confissão não vejo como importante. Se o investigado entrega o "serviço" na base de tortura "aceitável", como por exemplo o "saco" onde consequentemente se acha a arma do crime, a droga, não se faz necessária a confissão. Afinal, são raros os casos de confissão espontânea em treze anos de polícia e de experiência na área” (C12). 


\section{Dimensiones histórico-sociológicas de la tortura en comisarías de Brasil: el caso Pernambuco}

ccxcvii - "Sim” (C13).

ccxcviii - "Uma técnica que a gente observa e que até já está se comentando que deve ter o cuidado para não ficar usual, é a parte de inteligência e, principalmente, da interceptação telefónica. A gente vem observando que o uso dessa técnica permite que você formalize a prova do crime $e$ a identificação de autoria. Existe informação de quem seria autor ou praticante de determinado crime, aquela pessoa a partir de um determinado caso passa a ser investigada usando essas técnicas de interceptação e outras e se chega realmente a prova e formalização da autoria e são realizadas prisões e pelo que tenho conhecimento não precisa dessa prática” (CA6).

ccxcix - "Tenho observado que depois da utilização das escutas telefônicas houve um incrementos das investigações. Elas se tornaram mais eficientes e os delegados que trabalham com ela em geral não recorrem à tortura. Mas ainda é pouco utilizada” (C3).

ccc - "Privilegie os que usam as técnicas de inteligência. Disponham ferramentas de trabalhos e metodologia”. (C2).

ccci - "Vários, vários. A própria inserção do método de polícia comunitária. Onde a população se torna um terceiro olhar da polícia. Trabalhar com Serviços de informação, a própria inteligência tecnológica que hoje dispomos é um meio que auxilia demais nas investigações. Então assim, a própria polícia está investindo nela, logisticamente e está facilitando bastante o processo investigativo. Diferentemente do tempo de meu pai, por exemplo, em que segurava o cara e, rapaz, era na pancada. Só tinha esse método. E o pior é que existem resquícios ainda desse tipo de policia no nosso meio... Tem policiais ainda na ativa que foram do antigo DOPS... A ditadura foi ontem... Onde se era lícito torturar... Então, como tirar da cabeça desses policias que a tortura não dá resultados?(...)” (Al).

cccii - "Inteligência policial. Quando você dá um passo a frente naquilo que o bandido vai fazer. É o melhor método que a Polícia Civil tem, embora não possa abranger todo o Estado” (A2).

ccciii - "Falta ensino e gestão. Primeiro que não ensinam as técnicas mais necessárias na Academia. Segundo que os gestores não estão capacitados para instigar seus subordinados a empregá-las" (C3).

ccciv - "Me sentia mal, o delegado ele terminou tendo, isso foi antes da CF88, eu era opinião minoritária, alguns também se incomodavam porque principalmente quando ele agredia um cara que não tinha cometido crime. Ou seja, se tivesse cometido algum crime ainda era justificável o espancamento, no pensamento dominante da polícia naquela época. E eu me sentia muito mal com a presença dele inclusive, com estas atitudes. $O$ cidadão vinha prestar uma queixa, um BO, e já teve cidadão que foi espancado lá” (C1).

cccv - "Eu me senti muito mal, mas não queria que os policiais militares percebessem e achassem que eu era fraco ou não tinha peito para ser policial. Fingi que era a coisa mais normal do mundo, conversei com o oficial o assunto que tinha para tratar com ele, ainda perguntei se o preso tinha vomitado alguma coisa (dado alguma informação) para parecer o mais tranqüilo possível” (C3).

cccvi - "Procuram estar ausente da pratica, demostram constrangimentos em ter que admitir" (C2). 


\section{Dimensiones histórico-sociológicas de la tortura en comisarías de Brasil: el caso Pernambuco}

cccvii - "Nunca presenciei não. Eu realmente acho que nunca quis pensar nisso não. Mas assim, eu acredito que eu vou tentar impedir que aquilo aconteça... e sinceramente não sei como seria o desenrolar, se eu iria formalizar aquilo para que fosse apurado, não sei, ia depender da situação eu acho, realmente eu não sei" (CA6).

cccviii - "Interferiria seguramente e, como não confio nas unidades corregedoras internas, encaminharia uma denúncia ao Ministério Público” (CA5).

ccix - "Dependendo do caso, pela realidade que vivemos, veria com certa normalidade, mas com a certeza que não poderia me eximir da responsabilidade penal” (C2).

cccx - "Se fosse praticado por subordinado meu não permitiria. Se for praticada por um colega delegado, desaconselharia” (C4).

cccxi - "Eu já presenciei e não gostei. Hoje reajo muito e tento conter os agentes para não agirem com excesso, no entanto, muitas vezes sinto que é necessário, infelizmente. Mas tento sempre sentir se aquela pessoa realmente merece aquilo, se tem antecedentes ou se tenho a certeza do cometimento do crime" (C12).

cccxii - "Hoje, no ambiente que trabalho eu sou declaradamente contra a tortura... Veja bem, hoje eu sou contra todo e qualquer tipo de tortura. Mas recentemente aconteceu um crime de grande complexidade, envolvendo, em um lugar ermo, um homicídio e um estupro, e a única vitima era a pessoa estuprada. E a única coisa que ela lembrava era de pequenas características do acusado, algumas tatuagens. E saímos em busca do acusado até que o encontramos. Como resolver isso? E como agir diante de tanta certeza que era ele? Ele evidentemente não ia confessar. E houve tortura e ele confessou, dando detalhes. Tanto é que a tortura se deu no local do fato. E ele confessou sob ação de tortura. E eu tenho certeza que se assim não fosse feito ele não falaria. (...). o que eu entendo... a tortura é um crime e como todo crime, tem seus excludentes (...) eu acredito nos casos que... é complicado porque tudo depende do caso concreto... Existe situações em que precisa da materialidade do crime e no caso do... Mas voltando à resposta eu sou contra e declaradamente contra a toda forma de tortura. Não existe mais tortura diante de mim... é complicado... enfim, particularmente, eu acredito que nos casos que eu acreditasse que precisava muito acreditar que se tinha aquela informação e eu poderia obter aquela informação eu torturaria sem problema algum" (A1).

cccxiii - "Eu seria omisso. Não participaria não. Também não denunciava, nem daria conselhos. Não vi nada, não vi nada, não vi nada, não sei de nada” (A3).

cccxiv - "Não sei... Não sei...” (C3).

cccxv - "Se fosse possível evitar, é isso que faria. Também poderia investigar e tentar punir policiais que agissem desse modo" (C13).

cccxvi - “(...) hoje, é muito complicado isso, quando você, hoje eu tomaria atitude, mais experiente, mais maduro, mesmo naquela idade, sabendo o que sei hoje, não trabalharia mais naquele local, por exemplo. Mas na época, eu não fiz isso, o delegado era avisado e não se incomodava e agente via que aquele cara era muito desequilibrado, mais que a média” (C1). 


\section{Dimensiones histórico-sociológicas de la tortura en comisarías de Brasil: el caso Pernambuco}

cccxvii - "A maioria deles não tortura, mas ignora, posto muitos agentes afirmarem que não existe outra forma para investigar determinados crimes, convencendo assim o delegado, pois esse quer sempre ter sucesso em suas investigações e infelizmente tem que se submeter a tais métodos” (C12).

cccxviii - "Hoje felizmente, prevalece os delegados legalistas, que não compactuam com a tortura. Os agentes costumam agir de acordo com a orientação do delegado, então, a tortura diminuiu bastante" (C13).

cccxix - "Hoje que a gente tem o direito de falar mais alto e eu digo não faça isso não que você vai ser punido. Vou comunicar, vou escrever, vou fazer uma ocorrência. Não admito que faça isso onde trabalho. A primeira coisa que digo é não admito violência. A PM também chega com aquelas violência deles eu digo vamos fazer isso não, porque hoje todo mundo tem uma câmera no celular, tem os direitos humanos e vai sobrar. Aí eles diminuem mais a violência” (A4).

cccxx _ "Precisei. Pra civil e militar".

cccxi - "Precisei. E no último ano também” (A4).

cccxxii - "Se condena muito mais a corrupção que a tortura. A tortura, às vezes, é até tolerada quando digamos tem um policial Y que tortura, mas as pessoas o têm como não corrupto. É até suportada. Como eu conheço um delegado de polícia que as pessoas sabiam, brincavam em público, e, como que toleravam, depois eu soube que certos atos que ele fazia, qualquer psiquiatra, qualquer pessoa consciente iria considerar como una coisa doentia (si refiriendo al entrevistado C10). E não é cem por cento certo que não fosse corrupto também, mas tinha essa aparência de ser apenas torturador. $(\ldots)$ (..) $(C 1)$.

cccxxiii - "Sim” (C2).

cccxiv - "Sim, de forma velada” (C4).

cccxv - "Sem dúvida. Todos que conheço, conhece algum caso de tortura e nunca vi una reação indignada ou algum movimento para extingui-la. Se isso não for tolerância eu não sei o que é” (C3).

cccxvi - "Evidentemente” (CA5).

cccxvii - "Hoje anda diminuindo com a existência de métodos modernos de investigação, como a interceptação telefônica. No entanto, diante das dificuldades do judiciário em analisar ou demorar a analisar, as provas podem sumir e a única forma de fazer com que isso não aconteça é utilizar os métodos ilegais" (C12).

cccxviii - "Ainda há tolerância, apesar de ter havido diminuição significativa nos últimos dez anos" (C13).

cccxix - "Existe. Existe sim. Eu creio que na instituição é licita a tortura, desde que não descoberta. Hoje existe uma dinâmica da instituição pela busca incessante de resultados. A instituição quer resultados, a instituição quer autoria, quer materialidade. Logico que ela é contra a tortura, ela pune os torturadores, isso é evidente, como uma instituição legal, ela pune, mas na medida que ela te diz. 


\section{Dimensiones histórico-sociológicas de la tortura en comisarías de Brasil: el caso Pernambuco}

que quer esses resultados pra ontem, e não te dá recursos, ela implicitamente, tacitamente, tá te dando um aval pra torturar, com uma ressalva: olha, quem segura a bomba é tu. E as vezes o torturador é um torturado porque ela tá, não na tortura física, mas naquela tortura psicológica porque eu tenho uma chefia, pra preservar essa chefia, esse pluri, eu tenho que dar resultados..." (A1).

cccxx - "Eu acho que há. Porque existe uma total, total, busca do resultado. Hoje na PC Pernambuco ela quer o resultado e muitas vezes ninguém tá se importando como esse resultado será obtido. Você simplesmente chega para um subordinado e diz eu quero determinado resultado para amanha. E você diz, mas eu não tenho as condições que preciso... Dê seu jeito, mas eu quero esse resultado para amanha... Então hoje eu acho que a Polícia Civil está fanática por números. A Polícia Civil não esta preocupada com a qualidade de seus serviços, nem como está o policial, nem o que ele precisa... Ela tá preocupada que, se houve 5 homicídios naquela área eu quero 5 homicídios solucionados... Se você disser eu tenho o resultado ela não quer saber como foi obtido o resultado... Então mande isso pra mim que vamos alimentar uma planilha, que vai alimentar uma planilha, que vai alimentar tal planilha que vai chegar ao Governador... Então hoje eu acho que indiretamente a própria Polícia Civil não só está influenciando, como incentivando a prática da tortura... No mínimo ela está sendo omissa de não se preocupar como os policiais estão chegando a tais resultados” (A2).

cccxxi - "Ele é uma pessoa muito extrovertida, faz amizade com muita facilidade e é uma pessoa divertida... Então assim, embora se tenha conhecimento dessa praticas dele, ele não é rechaçado, ele é uma pessoa divertida, ele é uma pessoa... é por aî” (CA6 si refiriendo al entrevistado C10).

cccxxii - "Se são de hierarquia superior ao do delegado torturador, se omitem, desde que o resultado seja obtido. Tal conduta até estimula a prática da tortura. Se do mesmo grau hierárquico, apenas tomam conhecimento" (C4).

cccxxiii - "Em geral toleram com algum limite. Eles conduzem esse limite, mas tem o discurso de evitarem a violência” (CA5).

cccxxiv - "Quando é só torturador ele tem uma aceitação muito maior. Fulano faz isso, mas fulano é trabalhador, é empenhado. Muito mais grave que furtar é o crime de torturar para descobrir a autoria do crime" (C1).

cccxxv - "Em geral em não penso nisso. Não falamos sobre isso. Falamos quando o policial é corrupto, mas não comentamos quando ele tortura eventualmente. É como se fosse um mal menor. A menos que seja um psicopata ou sádico...” (C3).

cccxxvi - "Sim, até mesmo demitido dos quadros por não praticar ordem superior” (CA5).

cccxxxvii - "Sim. Foi visto como policial fraco e pouco prático. Ineficiente” (C2).

cccxxviii - "Eles inclusive, posteriormente me apelidaram de "empata foda”, o delegado que é contra a tortura é visto pelos seus subordinados como empata foda, aquele que, é una coisa muito, aparentemente una brincadeira de mau gosto, mas é muito séria porque o cara tá dizendo que tem prazer, porque a foda que a gente conhece é una coisa prazerosa e quem nos impede de ter una foda está nos impedindo de ter prazer. Então quem impede tortura não é impede foda é empata crime. Empata sofrimento" (C1). 


\section{Dimensiones histórico-sociológicas de la tortura en comisarías de Brasil: el caso Pernambuco}

cccxxix - "Já sim. Os policiais melhores, como disse, rechaçam os policiais tidos como "medrosos", dizendo que eles não querem trabalhar ou não sabem ser policiais e sei também que a maioria não tortura com medo de responder processo, pois muitos estão buscando novas carreiras” (C12).

cccxl - "Nunca vi uma retaliação expressa, mas tacitamente era muito comum os policiais se reportarem a esse policial como preguiçoso somente porque ele não compactuava com tortura" (C13).

cccxli - "Efetivamente rechaçado... não sei. Realmente ele é apontado né, como muito legalistacccxli, muito certinho, são termos que usam pra identificar. Mas eu acho que isso não é una forma de constranger não" (CA6).

cccxlii _ "Rechaçado não. Mas já vi ser rotulado como radical ou legalista. Um cara pouco flexível, sem jogo de cintura...” (C3).

cccxliii - “Já vi na PM... Na Civil, não” (Al).

cccxliv - "Varias vezes, varias vezes, tanto na polícia civil, quanto na PM. Quando você entra numa guarnição o mais antigo diz, é o seguinte, é VOC: ver, ouvir, calar. O que você vê aqui, fica aqui. Se você não se adapta a isso você diga que eu vou botar você pra dar guarda na cadeia, numa cadeia que está com o teto caindo na sua cabeça; se você não tem estômago para trabalhar dessa forma eu vou botar você para trabalhar numa permanência; você não vai ficar na viatura. Ou você tem o perfil pra ficar numa viatura ou você não tem. E hoje eu vou dizer, no mínimo, mesmo com toda essa cultura de direitos humanos, mais de $50 \%$ do nosso efetivo vai usar da força se necessário” (A2).

cccxlv - "Já, já vi. Mudavam de delegacia, diziam, ó tu não dá pro serviço não, tu é muito calmo, uma moça, vá pra gabinete, procurar um serviço administrativo” (A4).

cccxlvi - “Já, já... Poucos... porque em sua maioria praticava. Esses poucos não se misturavam, eram tidos como frouxo, um cara que em vez de ajudar atrapalha, prejudica o trabalho da polícia, não é polícia. Vá ser professor de balé Vá pra outro lugar, não aqui na polícia. Seu perfil não é de polícia. Você veio para o lugar errado. Va pra escola ensinar... era completamente excluído” (A3).

cccxlvii - "Depende, cada caso é um caso, digamos. Nesse momento que não houve ação nossa existia toda a cultura policial de que aquilo era una coisa correta. Você sozinho dizer que aquilo está errado você não tem nem para onde ir (...). O grupo como um todo, não só daquela unidade. Isso também porque também tinha aquela questão de que as pessoas que cometiam o crime eram do mesmo nível hierárquico, eram subordinados. Tanto os que observavam o crime como quem praticava. Aí fica mais difícil a ingerência, você tem que tomar a medida radical de sair, abandonar o serviço e procurar no outro dia o setor e dizer porque tá querendo sair dali. (...)” (C1).

cccxlviii - "Se for um policial bem visto pelos demais você passará a ser um traidor do dia para a noite. Vai parecer que foi você que cometeu um crime" (C3).

cccxlix - "Sim. Não com os seus subordinados, pois você chega e diz eu não aceito isso e quem só sabe trabalhar assim que mude para outra delegacia ou arque com as consequências. Tá resolvido. Mas com os outros é diferente. Se você chega em una roda onde alguém está divertindo um grupo 


\section{Dimensiones histórico-sociológicas de la tortura en comisarías de Brasil: el caso Pernambuco}

contando como torturou um criminoso e você diz que não tolera esse tipo de brincadeira ou prática, vão pensar: é louco, chato, inconveniente, qualquer coisa desagradável. Se você entrar em una delegacia e vê que estão torturando e tenta impedir ou vai para a corregedoria denunciar, você vai ser tratado muito mal por seus colegas" (C3).

cccl - "De certa forma” (C2).

cccli - "Creio que a algúm tempo atrás, dependendo do seu nível funcional esse tipo de problema poderia ocorrer. Mas tem diminuido bastante esse tipo de ocorrência” (C13).

ccclii - "Muitos o são, inclusive eu. Muitos policiais dizem: quer que se descubra onde está a arma, a droga, então não tem outro jeito, solta” (C12).

cccliii - "Eu nunca vou ser condescendente com essa prática não... Tem alguns lugares onde dizem que acontece ele tipo de situação, que aqueles crimes investigados ali somente são obtidos mediante ele tipo de prática... Mas assim, o meu receio de ir para lá não é por talvez ter que praticar isso, que eu não iria fazê-lo, certo, mas é pelos policiais que vou encontrar lá, que não sei se eu teria autorização para tirá-los todos, para eu trabalhar com quem eu quiser" (CA6).

cccliv - "Veja bem. Na minha presença não faz. Se estão fazendo lá e eu sei, também não vou lá (...) porque eu acredito que se ele tá fazendo lá ele busca algum resultado, se ele tá fazendo é porque alguém está autorizando, então é uma teia muito grande que eu particularmente não me meto (...)" (A1).

ccclv - “Não. Não é necessário você agir dessa forma, agora é necessário você procurar o seu espaço. Porque a polícia é como uma grande família, você vai ter um espaço se você o procurar e fizer por merecer. Tem equipe que trabalha só com tortura, tem, tanto na PM quanto na Civil, se você não se enquadra naquilo cabe a você vai procurar o lugar onde você se enquadra melhor para trabalhar $e$ você vai ser respeitado por isso. O que acontece muito na PM e um pouco na Civil é se você tentar ocupar um espaço que não the cabe. Você quer trabalhar numa guarnição de rua e você não tem estômago pra isso, mas você quer, você acha bonito tá numa viatura, mas o grupo não vai lhe aceitar. Se você mantém o vínculo de amizade com esse grupo, mas sabe que se identifica melhor num trabalho burocrático, aquele grupo que trabalha na rua vai lhe respeitar. Hoje em dia a melhor forma, e o que mais ocorre é você fingir que você não vê. Porque se você começa a se meter nesse trabalho, como está sendo feito, você vai ser tido como entregão, aquele que a qualquer momento pode entregar o colega à corregedoria. Então, hoje, na prática, você se omite. Ou você se omite ou você troca de lugar" (A2).

ccclvi - "É, exatamente, finge que não tá vendo, dá as costas” (A4).

ccclvii - "Nunca. A mim não importa ter ou não ter problemas com colegas de trabalho. Nunca fui condescendente com praticas nem corruptas nem violentas. As duas são de igual gravidade” (CA5).

ccclviii - "Não” (C4).

ccclix - "Já o fiz, quando vi que a pessoa que começava a ser torturada nada tinha a ver com o crime e eles me respeitaram, como sempre respeitam” (C12). 


\section{Dimensiones histórico-sociológicas de la tortura en comisarías de Brasil: el caso Pernambuco}

ccclx - “Creio que não” (C13).

ccclxi - "Eu acho que o crime de tortura é muito difícil da gente conseguir caracterizar. A corregedoria, como é a realidade da polícia, eles têm uma demanda maior do que o efetivo pra apurar. E a gente esbarra, eu já investiguei casos desse tipo e a gente esbarra em algumas dificuldades. Que é a materialização, nem sempre o laudo traz os indicativos das lesões, nem sempre tem, a gente fica com a versão do policial contraria a versão da vítima da tortura, e é claro que são divergentes e a gente não tem una terceira pessoa diante da falta do laudo, ou então da materialidade, que auxilie pra ajudar, a saber, com quem tá com a verdade. É um crime muito difícil... Então eu não sei se ela poderia ser mais eficiente ou não” (CA6).

ccclxii - "Ela não pode punir de forma eficiente porque não tem estrutura suficiente. E olha que no nosso Estado ela até que está bem. Eu conheço outros Estados onde a situação é bem pior. E não é só a questão de punir. Tão importante quanto, é a questão de fiscalizar e orientar. A punição seria a última fase e a corregedoria não consegue fazer bem nenhuma delas” (C3).

ccclxiii - "Não. Pelos pífios índices de apuração dos casos, ou até mesmo inexistentes” (C2).

ccclxiv - "Não. Primeiramente, há una dificuldade muito grande para denunciar a prática de tortura (o medo prevalece). Em segundo lugar há a questão da prova, quando o tipo de tortura empregada não deixa vestígio. Por fim, existe um sério problema que é o fato de que os corregedores são delegados de polícia que, investidos momentaneamente daquela função, julgam colegas, os quais poderão estar em outra ocasião, investidos na função de corregedores" (C4).

ccllxv - "Eu acho que tem poucos casos assim. Eu acho que ela pune, mas o problema é que talvez o número de punições seja muito inferior a prática da tortura que existe. É de difícil prova, porque muitas vezes não deixa vestígios, é a palavra da vítima contra a palavra do policial” (C1).

ccclxvi - "Depende se o torturador tem ou não una boa proteção política interna. Se não tem, ele é punido severamente para servir de exemplo. Mas a pratica das investigações das corregedorias é mais severa com crimes de corrupção do que tortura. Ainda há uma certa tolerância em muitos casos. Não há una clara interpretação da própria corregedoria do que seja ou não seja tortura. As orientações internas são deficientes e não há uma formação que previna e combata a pratica de torturas" (CA5).

cclxvii - "Não consegue. Difícil provar. O chamado "saco" não deixa marcas. É a palavra do bandido contra a da polícia. Geralmente não se tem testemunho. Abre-se IP e nada. Só se houver morte e a coisa for descarada, o que é difícil ocorrer" (C12).

ccclxviii - "Não, pois muitas não deixam vestigios e outras vezes a pessoa tem medo de denunciar" (C13).

ccclxix - "Nos últimos anos, não só a corregedoria da Polícia Civil, mas da SDS tem sido implacável. Chega a ser até um tribunal de exceção... Foi tortura, fazem um PAD e vão ser bem rigorosos... até porque existe ONG e toda uma cobrança em cima deles" (A1).

ccclxx - "Sim. A corregedoria hoje vem fazendo um trabalho que eu não vi isso há sete anos atrás... Hoje, você trabalha nos plantões e chega uma ocorrência, você quer se livrar daquele cara. Porque o 


\section{Dimensiones histórico-sociológicas de la tortura en comisarías de Brasil: el caso Pernambuco}

delegado não quer que a corregedoria chegue lá e pergunte: o que esse preso tá fazendo aqui? Por que não foi para o presídio?... Então, se a corregedoria tá impondo esse medo é porque ela tá dando resultado é porque ela tá punindo alguém. Agora se falta corregedoria não tem efetivo para o Estado todo, como é que um efetivo reduzido vai fazer efeito?" (A2).

ccclxxi - "Quando vem cair é que já fez mais de mil” (A4).

ccclxxii - "Ela pune eficiente, mas algumas vezes exagera. Extrapola um pouquinho, por que algumas vezes dificulta a defesa do policial. Acredito eu. Coloca casca de banana para dificultar a defesa do policial" (A3).

ccclxxiii - "Não. Creio que quem não pratica é pelos seus próprios valores ou por medo que venha a tona e o Ministério Público faça una denúncia. A gente até esquece que a corregedoria existe” (C3).

ccclxxiv - "Inócua” (C2).

ccclxxv - "Deficiente. A corregedoria age muitas vezes pressionada por entidades externas. Não demonstra claramente que tem una política interna e moderna voltada para a demolição especifica da tortura. Todas as infrações estão no mesmo nível de importância. A punição é que vai variar segundo as circunstancias do cometimento ou do 'status' do policial” (CA5).

ccclxxvi - "Pouca, não conheço nenhum caso de agente policial que tenha sido demitido por praticar tortura" (C13).

ccclxxvii - "A fiscalização influencia. No entanto, na corregedoria da polícia onde trabalho estão os maiores torturadores da PC que hoje preferem combatê-la” (C12).

ccclxxviii - "Eu acho que sim. Agora depende de cada caso. Deixam de praticar, diminuem ou tomam mais cuidado. A partir do momento que a Corregedoria atua mais, tem mais casos punidos, quando os crimes de tortura são revelados, que a corregedoria atua o cara foi demitido, o cara foi punido. Então isso inibe" $(\mathrm{Cl})$.

ccclxxix - "Quem pratica a tortura passa a ter mais cuidado para não deixar vestígios" (C4).

ccclxxx - "Sim. Algumas vezes isso é importante para não haver injustiça, algo muito comum quando você é avaliado por alguém que não tem idéia do que é o seu trabalho, nem em que condições você trabalha. Mas também tem o lado de você não querer se queimar com os seus colegas" (C3).

ccclxxxi - "Isso talvez exista em algumas pessoas. Eu não vejo como sendo una imagem da corregedoria. Não vejo assim não.

Creio que a maior dificuldade é operacional e a própria dificuldade do crime. É a questão de materializar. Muitas vezes a pessoa, a vítima da tortura naquele primeiro momento que ela se revolta com a prática ela vai atrás de una providencia, ela comunica, ela notifica os órgãos que seriam os de atribuição para conhecer e apurar aquilo ali, mas como não se tem condições de dar una prestação ágil, então a própria demora, quando a gente vai atrás daquela informação, para melhor conduzir a investigação as pessoas já tem passado aquele primeiro momento, elas às vezes não colaboram mais da mesma forma como estariam dispostos naquele primeiro momento e isso atrapalha”. (CA6). 


\section{Dimensiones histórico-sociológicas de la tortura en comisarías de Brasil: el caso Pernambuco}

ccclxxxii - "Enquanto eu respondia a questão anterior eu estava pensando, só de tortura, eu não lembro, mas houve, mas eu não lembro”. (C1).

ccclxxxiii - "Pessoalmente por tortura não". (CA5).

ccclxxxiv - “Não”. (C2).

ccclxxxv - “Não. Nenhum”. (C3).

ccclxxxvi - “Não. Pelo menos não recordo”. (C4).

ccclxxvii - "Tortura especificamente... Eu também não acompanho os resultados... Mas eu escuto mais falar em afastamento e demissão em decorrência da corrupção... De tortura especificamente eu não me lembro não”. (CA6).

ccclxxxviii - "Não”. (C13).

ccclxxxix - "Não”. (C12).

cccxc - "Conheço pessoas da minha turma e antigoes que perderam o cargo por tortura que resultou em morte. E é interessante que esses três policias é um com mais de 30 anos de polícia, outro com mais de 10 anos de polícia e outro que é da minha turma, com 3 anos de polícia”. (A1).

cccxci - “Conheço militares. Policiais civis, não”. (A2).

cccxii - "Conheço uns 4. Foram duas torturas que foram famosas aqui em Pernambuco e o cara não aguentou e morreu. (A4).No meio policial ele é discriminado”.

cccxciii - “Por tortura, não”. (A3).

cccxiv - "Se a apuração da tortura fosse mais frequente, ela tivesse una prioridade e os resultados daquelas investigações fossem amplamente divulgados eu acho que isso serviria também para inibir um pouco a prática. Porque infelizmente em alguns casos de irregularidades praticadas por policiais elas não são apuradas. Os gestores, digamos assim, eles tomam conhecimento que um determinado delegado, agente ou escrivão tem una conduta irregular, mas aí não se busca materializar aquela conduta para que seja punida. Que é que se faz? Transfere-se ele de una unidade para outra, como se aquilo ali talvez fosse fazer com que ele não mais usasse aquela prática. Ou afasta ele temporariamente da atividade, ele fica em stand by, sem função especifica, sem unidade para trabalhar". (CA6).

cccxcv - "Para mim, é o mesmo que ocorre com outros crimes. Se não houvesse tanta impunidade não haveria tanta tortura. Precisamos de campanhas de conscientização que façam o delegado perceber que não é normal praticar. E precisamos também de punições para os que insistam em praticar". (C3).

cccxvi - "É difícil ser combatido. Se eu identifiquei que ele diminuiu não foi una ação institucional, não é una campanha para que acabe”. (C1). 


\section{Dimensiones histórico-sociológicas de la tortura en comisarías de Brasil: el caso Pernambuco}

ccccvii - "Tem muitos casos que a gente depende de depoimentos de testemunhas que a gente nem sempre consegue com tanta facilidade, que a gente não tem como garantir segurança, reserva do que foi relatado e, consequentemente segurança para aquela pessoa. Mas é ainda muito importante a informação de quem ouviu falar e de quem presenciou o fato". (CA6).

cccxcviii - "Não sei se ocorre muito, mas acontece. De existir una mudança, às vezes dá una impressão que foram ameaçadas, mas elas não dizem que foram”. (CA6).

cccxix - "É comum eles não dizerem nada do que viram para não sofrerem ameaças ou mesmo serem mortos. Já vi casos em que as testemunhas de homicídios (quando são grupos de extermínios) foram mortas depois de seus testemunhos. E, finalmente, é muitíssimo comum una testemunha que quando chega em juízo, e depois de ameaçada pelos criminosos, muda todo o depoimento dado na delegacia. É muito difícil trabalhar assim!(...) Em alguns casos é como se a única forma de chegar à verdade fosse através de una testemunha, mas, ao mesmo tempo, pressioná-la para testemunhar fosse como condená-la à morte”. (C3).

cd - "Ás vezes é porque eles não tem realmente nenhum indício, nenhum indicativo para iniciar aquela investigação... O que eu acho é que infelizmente ainda existe o corporativismo e para algumas pessoas não é interessante que isso seja investigado... Porque os chefes também teriam em algum momento utilizado daquela pratica, porque talvez aquele policial já fez algum favor para o chefe e aí o chefe vai retribuir aquele favor.(...) E às vezes é falta de coragem mesmo. Eu acredito, em alguns casos, não só na investigação da tortura porque tem determinados policiais que se tem conhecimento de que realmente eles são muito contundentes nas práticas irregulares e eu acho que existe medo, eles são temidos”. (CA6).

cdi - "Da coragem deles em determinadas condutas. Em práticas criminosas, não especificamente violentas, de tortura”. (CA6).

cdii - "Com relação ao MP e Juiz não. Com relação aos colegas, sim, sofri pressão. É muito difícil investigar tortura". (CA6).

cdiii - "Conheço. O policial quando é acusado de tortura, principalmente se ele está sendo acusado por alguém do mundo do crime, primeiro ele acha que nem deveria estar sendo investigado, porque é una coisa menor..." (Cl).

cdiv - “Conheço alguns”. (C4).

$c d v$ - "Sim”. (C2).

cdvi - "Sim. Conheço uma delegada que sofreu muita pressão porque estava apurando um caso de tortura. Os colegas ligavam para Ela, censuravam sua conduta, pois alegavam que o investigado não era nenhum bandido”. (C3).

cdvii - "Sim. Comigo mesmo já ocorreu. Acabei afastado do inquérito ao argumento de que deveria assumir outra delegacia e esta era muito movimentada o que me impediria de continuar na investigação”. (C13).

cdviii - "Não". (C12). 


\section{Dimensiones histórico-sociológicas de la tortura en comisarías de Brasil: el caso Pernambuco}

cdix - "Eu não diria pressão, mas há uma rejeição branca. Ele não é bem visto, ele não é bem aceito. Ele não é chamado para tomar um chope”. (A1).

$c d x$ - "Essa visão é corriqueira. Policial que trabalha na corregedoria ele não é bem quisto. Ele é mal visto. Se ele tá ali é pra te prejudicar sempre... Na cabeça dos policiais ele tá ali porque ele quer se destacar em cima do seu erro. Ele quer fazer aquele feedback ao contrário, ele quer lhe prejudicar pra mostrar resultado ao chefe dele..." (A2).

cdxi - "No meio policial ele é discriminado. De qualquer forma ela está fiscalizando seu trabalho $e$ ninguém gosta de ser fiscalizado”. (A3).

cdxii - "Com relação à CF especificamente eu não acredito que tenha alterado, talvez eu acredite que hoje, de uns dois anos para cá, pela própria mudança, em algumas situações dentro da polícia, eu acho que isso diminuiu um pouco, até os instrumentos de investigação que facilitam a prova do crime, realmente isso eu acho que diminuiu. Não há por que mais fazer”. (CA6).

cdxiii - “Existe menos, face à vinda de novos quadros e una pequena melhora na investigação”. (C2).

cdxiv - "Não tenho dúvidas quanto a isso! Menos pela reprovação da Constituição à tortura, mas pelos poderes que deu ao MP e, principalmente, pelo ingresso de novas gerações à polícia (graças à imposição de concursos públicos). Os novos delegados não têm o perfil de antes e são cada vez menos tolerantes com a tortura”. (C3).

cdxv - "Se pratica menos que antes. Não creio em influência da Constituição ou de lei ordinária porque quem pratica a tortura o faz com conhecimento de sua ilegalidade. O que mudou foi a nova geração de policiais, que ingressaram na instituição através de concurso público, que não aceitam essa prática antiga”. (C4).

cdxvi - "Evidentemente que sim (hubo reducción). Porque existem novos atores também responsáveis pelas garantias constitucionais individuais. A sociedade com um todo é mais cidadã e questiona mais as arbitrariedades cometidas pela polícia, além claro do papel do ministério público de exercer o controle externo das atividades policiais. A Academia esta um pouco mais sensibilizada para o tema, mas sem tudo, ter una política clara de formação para os direitos humanos”. (CA5).

cdxvii - "Menos. Sim, creio que a Constituição ao vedar algumas praticas como a prisão para averiguação e instituir alguns mecanismos de controle e a liberdade de imprensa contribuiu. Ficou famoso no Recife o caso em que foi encontrada em uma delegacia uma palmatória" (instrumento de tortura). (C13).

cdxviii - "Menos, com certeza. A fiscalização é mais intensa. Sim, o art. $5^{\circ}$ que trata dos direitos fundamentais age diretamente em relação às leis que punem a tortura e a prática investigativa ilegal”. (C12).

cdxix - "Claramente. O Ministério Publico é de fundamental importância na diminuição da tortura nas delegacias policiais pelas denuncias que demanda”. (CA5). 


\title{
Dimensiones histórico-sociológicas de la tortura en comisarías de Brasil: el caso Pernambuco
}

\begin{abstract}
cdxx _ “(...) o MP passou a exercer o que eles chamam de controle externo da atividade policial. Que implica em visitas de promotores em delegacias, às vezes dois ou três promotores no mesmo momento, onde eles visitam as instalações físicas, eles pedem para ver e, são disponibilizados todos os livros de cartório, eles pedem relação de inquéritos instaurados e remetidos à Justiça, eles pedem quantitativo de efetivo, para ter una idéia da estrutura física da delegacia, coincidentemente isso começou a ocorrer também depois dessa mudança de, no meu entendimento, una mudança de pratica de investigação e pratica de administração... Isso vem ocorrendo há pouco mais de um ano... Não ouvi comentários, mas assim, como eles freqüentam e, nem todas às vezes avisam, é claro que eu acredito que quem têm determinadas praticas irregulares vai ter mais cuidado com essa práticas". (CA6).
\end{abstract}

cdxxi - "Eu creio que sim. Depois da CF de 88 o MP passou a ter um papel muito mais ativo. Eu tenho cuidado com o meu trabalho para não cair em suas mãos e vejo os colegas com o mesmo cuidado. Por isso acho que ele teve um papel importante na redução da tortura. Ainda que esse não fosse o objetivo deles. Pela pressão que eles exercem sobre a polícia”. (C3).

cdxxii - "Sim. Quando demonstra proatividade, adiantando a produção de prova e requisitando investigação a órgãos superiores, até mesmo de primeiro escalão de Governo”. (C2).

cdxxiii - “Sim, mas não tanto devido a sua estrutura deficiente”. (C13).

cdxiv - "Eu acho que é muito insignificante, é insignificante. Una das coisas que se devia preocupar com a tortura eram padrões de procedimentos no depoimento de vítimas, indiciados e testemunhas, existir perguntas obrigatórias sobre como elas foram tratadas pela polícia. Que elas tivessem essa oportunidade". (C1).

cdxxv - “Não. O MP está distante da polícia”. (C4).

cdxvi - "Não acredito. Pelo menos muitos promotores aqui no Estado não estão preocupados como solucionam o crime. Eles querem a solução”. (C12).

cdxxvii - "Eles são diligentes, eles procuram estar presentes em todos os atos, pelo menos é a minha experiência aqui, e cobram conclusão e agilidade no procedimento”. (CA6).

cdxxviii - "Na Capital muito mais, pois as relações são muito impessoais. Mas no interior eu creio que é a exceção, o delegado e o promotor, em geral, têm una boa relação e isso atrapalha una maior fiscalização do $M P$ ”. (C3).

cdxxix - "Não, elas ficaram estigmatizadas como sendo defensoras de bandidos, de modo que a própria sociedade não dá crédito a instituições que defendem direitos humanos, salvo em casos excepcionais, quando há erro e o torturado era inocente”. (C13).

cdxxx - "Essas ninguém vê falar. São caça níqueis”. (C12).

cdxxi - "Elas não são bem quistas pela polícia. Elas fazem um trabalho como o da imprensa... Elas tão ali para te cobrar, pra ver algo errado e mostrar, "ó tamos aqui te fiscalizando". É como se fosse uma corregedoria informal. Porque se uma ONG dessas te pegar fazendo algo errado...” (A2). 


\section{Dimensiones histórico-sociológicas de la tortura en comisarías de Brasil: el caso Pernambuco}

cdxxxii - "Da mesma forma que a instituição ela apoia desde que não lhe cause maleficio, desde não exponha a sociedade a uma situação de vexame, constrangimento. Mas nesse caso que citei de tortura a população queria linchar o cara, mas se ele morre, ah, a população é a primeira a pedir a punição dos policiais. É uma relação bem infiel entre policia e sociedade e entre sociedade e policia. É tudo questão de interesse”. (A1).

cdxxxiii - "Eu creio que a sociedade também apoia o resultado e não está preocupada em saber como foi obtido”. (A2).

cdxxiv - “Sim”. (C13).

cdxxxv - “E como. Em crimes violentos a maioria absoluta da população apóia”. (C12).

cdxxxvi - "Não". (A4).

cdxxxvii - "Apoiava, apoiava. Por que eles diziam, ladrão merece apanhar. O cara que batalha para conseguir um moto, um bicicleta... o miserável vem não sei da onde pra levar. Um fio da peste desse merece apanhar, tem que ir pro cacete... E os familiares não se revoltavam? Era a minoria, porque se se revoltasse ia pro cacete também. As vezes chegavam um pra reclamar e a gente dizia: tá achando ruim vai pro lugar dele. Aí eles diziam: não, não, não”. (A3).

cdxxxviii - “...A população é bombardeada com notícias de violência todos os dias e ela pensa ou sou eu ou são eles. Por isso que eles aceitam que a polícia seja tão violenta. É como uma guerra, onde vale tudo." (C3).

cdxxix - "A falta do Estado de poder capacitar seu policial para que ele consiga investigação através dos meios em que não seja necessário a utilização da tortura. Se o Estado não cumpre a parte dele de oferecer esses meios então ele tem que pelo menos ser condescendente para que a sociedade não fique a mercer de nenhum inquérito ser concluído, nenhuma investigação seja concluída...” (C14).

$c^{c d x l}$ - “... A instituição quer resultados, a instituição quer autoria, quer materialidade. Logico que ela é contra a tortura, ela pune os torturadores, isso é evidente, como uma instituição legal, ela pune, mas na medida que ela te diz que quer esses resultados pra ontem, e não te dá recursos, ela implicitamente, tacitamente, tá te dando um aval pra torturar, com uma ressalva: olha, quem segura a bomba é tu. E as vezes o torturador é um torturado porque ela tá, não na tortura física, mas naquela tortura psicológica porque eu tenho uma chefia, pra preservar essa chefia, esse pluri, eu tenho que dar resultados..." (A1).

cdxli - “(...) Então acredito que se aquele investigador não usar a tortura comumente ele pode ser mau visto pelos colegas e não ser considerado um bom investigador (...)”. (C14).

cdxlii - "Então via-se que a única forma que se obtinha exito nas investigações era com a prática da tortura. E então você tinha percepção ali que não era só você que estava fazendo e que diversas outras pessoas, principalmente as que se destacavam. Então ficava meio que quem não praticava a tortura eram os delegados que não queriam nada com a polícia...” (C14). 


\section{Dimensiones histórico-sociológicas de la tortura en comisarías de Brasil: el caso Pernambuco}

cdxliii - "Não. Eu acredito muito que, apesar da política de resultado, o chefe prefere um policial que não torture. Logicamente que seria meio que mágico... Então ele preferia o mágico, que conseguisse apurar sem torturar...” (C14).

cdxliv - "Exatamente, porque não se pode deixar de falar que existe uma certa eficiência. Se não tivesse resultado ela naturalmente acabaria por ser um meio obsoleto. Mas por haver eficácia nessa metodologia ela ainda sobrevive”. (A1).

cdxlv - "Se essa equipe, com tortura ou não, conseguir os resultados pretendidos pelos superiores, vai ascender. O que importa são os resultados”. (A1).

cdxlvi - "O agente ele quer ter uma relação de reconhecimento por parte de seu delegado. Ele quer que o delegado olhe pra ele e diga que ele tem um policial que me dá o resultado. "Eu tenho um policial competente; eu tenho um policial que eu confio, que eu vou dar determinado caso pra ele e ele vai resolver isso pra mim". Então o agente ele quer ter essa relação com o delegado. Ele quer que o delegado goste dele, que o delegado se sinta bem trabalhando com ele... Então, na maioria dos policiais civis, inclusive eu, quer fazer o seu nome na instituição, quer ser reconhecido. Cada um usa os seus meios pra fazer isso. Uns usam a tortura, outros usam meios burocráticos. Você quer conseguir seu espaço na polícia civil...” (A2).

cdxlvii - "Então a priori era uma coisa que me incomodava, mas depois passou a fazer parte do serviço. Em determinados casos específicos o uso da força era necessário pra chegar em determinado fim”. (A2).

cdxlviii - "onde só tem aquele comissário com a mão grossa pra levantar todo serviço, cairia drasticamente. Cairia drasticamente”. (A1).

cdxlix - "Na verdade a palavra certa, que era muito usada na época, não é tortura, é tirar serviço. Essa palavra tortura ela nunca é usada. Essa palavra tortura vem da época da ditadura... Então essa palavra tortura é muito usada por direitos humanos. Eles usam muito. Mas policia em si, desde que eu to dentro dela ninguém nunca usou. "Torturasse fulano? Vamos torturar sicrano, não. Vamos tirar serviço!”. Então quem usava muito essa palavra eram os militares, mas a policia investigatória, judicial, judiciária, não nunca usou esse termo”. (A3).

cdl - "Hoje eu já encontro, mas não tem os meios, os aparatos, nem o apoio necessário... Você tenta, mas a polícia não te dá isso... Então você tende a evitar chegar naquele caminho, mas é extremante difícil porque a cobrança permanece a mesma, polícia não quer saber que você mudou seu pensamento. Não quer saber de teoria, nem de filosofia. Ela quer saber que você não está dormindo. Ela quer o resultado. A cobrança continua e você fica naquele beco sem saída. Aí é quando ocorre o que está ocorrendo com boa parte dos policiais. Eles entram, não concordam, e vão embora... Você não vai mudar o sistema da Polícia Civil? Você não vai. Então a única solução que você tem é ir embora”. (A2).

cdli - "Infelizmente, pela ausência de uma prova científica capaz de elucidar os crimes... Com certeza, se diminuísse essa prática violenta diminuiria a elucidação de crimes”. (C14).

cdlii - "Nenhum. Eu não vejo nenhum ganho. Apesar de ter praticado, de ter obtido êxito em diversas investigações através desse meio cruel, eu não vejo ganho nenhum na prática da tortura. Acredito 


\section{Dimensiones histórico-sociológicas de la tortura en comisarías de Brasil: el caso Pernambuco}

que colegas, com certeza possam usar esses meios cruéis com intuito de ascender profissionalmente... pelo resultado que ela obtém. Como o Estado não oferece os meios e é condescendente com a prática criminosa..." (C14).

cdliii - "No interior, bandido não tem essa visão, então pra ele levar um pau da polícia tá mais do que certo, é o trabalho da policia...” (A2).

cdliv - "E é como se o cara, até por ser um contumaz naquela prática, ele até já estivesse acostumado, sabendo que tipo a polícia vai pegar, ela vai passar por aquilo”. (CA6)

cdlv - "Enquanto está dando certo, ele tortura com a mesma naturalidade que ele faz uma intimação ou registra uma ocorrência”. (C3)

cdlvi - "Certamente. A própria sociedade comunga com o pensamento de que o criminoso deve apanhar. Já me ocorreu de uma senhora que foi assaltada, ao descobrir que seu neto estava envolvido no crime me pedir para espancar ele". (C13).

cdlvii - "Se não conseguir provar ele vai ser favorecido. E tem pessoas que só vai no cacete, é da índole da pessoa. Não diz, de jeito nenhum, só diz se apanhar. Mas infelizmente, ou felizmente, hoje em dia não se pratica mais". (A3).

cdlviii - "A sensação do dever cumprido. A satisfação de chegar com o resultado para o chefe. Talvez queira ser mais policial, mais homem que o outro”. (A4)

cdlix - "Porque também tinha aquele que era efetivo, era ele que dizia: olha e primeira tapa é minha e o que der eu seguro. Como deu em algumas situações e ele segurou. Aconteceu algumas situações... E de grande proporção, e ele foi macho e segurou”. (Al).

cdlx - "Já, já vi. Mudavam de delegacia, diziam, ó tu não dá pro serviço não, tu é muito calmo, uma moça, vá pra gabinete, procurar um serviço administrativo”. (A4)

cdlxi - “Já, já vi. Quando eles são iguais, estão praticando a tortura entre iguais e um procura não fazer, realmente é taxado de covarde, mocinha, ou qualquer desse tipo. Até colega delegado já tiveram a sua masculinidade colocada à prova por no momento onde todos agrediam ele ficar fora $e$ essa é uma prática, realmente não deve ser aceita, mas já presenciei”. (C14).

cdlxii - "Já vi que é muito abafado, já vi que é frouxo, já vi que tinha que ser recruta”. (A1).

cdlxiii - "Esses poucos (los que no aceptaban la tortura) não se misturavam, eram tidos como frouxo, um cara que em vez de ajudar atrapalha, prejudica o trabalho da polícia, não é polícia. 'Vá ser professor de balett'; 'vá pra outro lugar', 'não aqui na polícia'. 'Seu perfil não é de polícia'. 'Você veio para o lugar errado'. 'Va pra escola ensinar...”’ era completamente excluído. (A3).

cdlxiv - "O diretor, que já morreu, uma vez me disse rapaz você só tem tamanho, força e moleza. Pra que esses músculos todinho se não serve pra bater em ninguém”. (A4). 


\section{Dimensiones histórico-sociológicas de la tortura en comisarías de Brasil: el caso Pernambuco}

\footnotetext{
cdlxv - "Tem aqueles que participam diretamente para mostrar à equipe que é durão. Tem aqueles que não têm coragem para fazer, mas querem que os agentes façam. Tem aqueles que nem têm coragem para fazer, nem coragem para assumir as consequências, então finge que não sabe...” (C3).

cdlxvi - “(...) e faz para mostrar a tropa que ele é um cara que tem que ser respeitado porque ele é capaz de fazer aquilo”. (C1).

cdlxvii $O$ bom torturador era tambem idolatrado e poderoso além de ser temido. Era reconhecido como um homem forte e muitas vezes líder. (C2).
}

cdlxviii - O objetivo é desmoralizar. Porque via de regra esses criminosos querem ser machões, o que cara que mata, que estupra, ele quer mostrar que ele é o tampa. E a questão sexual é desmoralizante. Ele prefere ser sangrado, prefere que arranque o olho, que levar um dedo no cu. Porque isso para o grupo, o grupo não aceita que o líder dele levou uma dedada, foi comido, foi botado o dedo no cu. Porque ele perde a moral dentro do grupo.(C15).

cdlxix - "Sinto saudade, sinto saudade. Porque hoje..., vou ser bem claro, as pessoas não respeitam mais, as pessoas hoje chegam na delegacia se achando, no mesmo direito, mesmo tando errado. Não respeitam o policial de plantão, não respeitam o delegado de plantão. Qualquer coisa procure meu advogado... Coisas que na época não acontecia... O cara vinha mesmo e se chegasse aqui $e$ aumentasse a voz, era xadrez dois, três dias... Era uma lição pra ele se enquadrar”. (A3).

cdlxx - "Infelizmente essa é a verdade. Na favela mesmo, eles só entendem na grossura. Se você falar educado ele acha que tá por cima, que a polícia tá com medo deles. Que ele tá levando vantagem sobre a polícia. Aí infelizmente é assim a vida do policial trabalhando na favela”. (A4).

cdlxxi - (...) "Naquele momento da raiva manifesta, apesar de não ser com você ou com a sua família, mas na hora da prática da tortura assume o policial aquele papel como se fosse com ele. Então a não confissão que leva a tortura faz como se tivesse desrespeitando a autoridade do policial, não tivesse atendendo a força imposta pelo policial, então isso o torna muito violento e é comum que os delegados ou virem as costas ou até temam tentar evitar. Eu vi situações onde eu fui inclusive chamado por um superior para tentar impedir uma prática de tortura que acontecia. Então o superior que estava no local e teria, em tese, a responsabilidade direta de impedir que isso acontecesse, você vê saindo de uma residência onde uma pessoa apanhava barbaramente (...) e a autoridade, que inclusive comandava a operação sair do interior da residência e pedir pelo amor de Deus, vá lá e vê se consegue parar com aquilo”. (C14).

cdlxxii - "Na PM. Na PM sim. Eles diziam: tu não sabe porra nenhuma não novinho. Tu tem que aprender novinho. Então sempre as repreensões eram de cunho, de forma a me marginalizar do grupo. Eles tocavam numa ferida, porque quem é novinho não quer ser chamado de novinho. Você quer ser parte do grupo, você quer ser parte importante do grupo, então quando eles tocavam nessa ferida. Já vi que é muito abafado, já vi que é frouxo, já vi que tinha que ser recruta. Então mexia no ego, de forma a marginalizar, e de certa forma dizer apoia que tu é do grupo. Você não entende nada, você não está apto a ser polícia”. (A1).

cdlxxiii - "Quando eu entrei aqui, logo no começo, no departamento eu era forte e aí o cara dizia novinho você vai bater em fulano...” ( A4). 


\section{Dimensiones histórico-sociológicas de la tortura en comisarías de Brasil: el caso Pernambuco}

cdlxxiv - “(...) não se misturavam, eram tidos como frouxo, um cara que em vez de ajudar atrapalha, prejudica o trabalho da polícia, não é polícia. 'Vá ser professor de balé; vá pra outro lugar, não aqui na polícia". "Seu perfil não é de polícia. Você veio para o lugar errado. Va pra escola ensinar...' era completamente excluído". (A3).

cdlxxv - "Você quer ser parte do grupo, você quer ser parte importante do grupo...". (A1).

cdlxxvi - "Muito me marcou em virtude da formação que eu tive (...) que não tinha em mente nenhum tipo de violência na nossa formação. (...) sempre fui avesso à violência (...) sempre me mantive distante de questões policiais, nunca mi vi dentro da policia, muito menos naqueles aprendizados horrendos que são da década de 60, que é do regime militar. Essa policia que nós aprendemos a conhecer era uma policia ostensiva, uma policia castigo, meramente de castigo. E isso sempre esteve muito distante da minha formação. E casualmente caí, né, no ramo do Direito (...). E já na universidade tive a oportunidade, né, de presenciar, raramente, más tive a oportunidade de presenciar esse horror que é a prática da tortura em nosso país. Através de alguns estágios como estudante de Direito em algumas delegacias de colegas que já exerciam a profissão, né, e aí eu passei a ver os mais diversos tipos de tortura, quando colegas, tais colegas que me levavam para conhecer um роисо o que era ser delegado de polícia, simplesmente se embriagavam para agredir presos indefesos que lá estavam. Presos pelas menores práticas criminosas, que não ofereciam qualquer risco a sociedade, mas que por terem delinquido estavam presos e serviam como instrumento de tortura para delegados alcoolizados que tinham isso como prazer, simplesmente. E, casualmente, enveredei pelo ramo do cargo de delegado de policia, onde sempre estive distante disso, meio que casualmente passei num concurso público. E nunca sequer me imaginei como delegado de polícia. Então toda essa minha formação foi surpreendida, realmente, ao assumir o cargo. A achar no exercício do cargo de delegado de policia que podia ser mais do que realmente o cargo impõe, o direito e o dever que o cargo impõe. Então no afã de dar uma resposta à sociedade esquecemos de todo o nosso aprendizado de vida, nossa educação de família humilde do interior do nosso país e passei a querer dar uma resposta para a sociedade da forma como a pouca experiência que tinha que era aquela experiência obtida através dos poucos momentos na cidade interiorana onde o amigo era delegado de polícia, ou seja, na base da tortura. Então não satisfeito com investigações, realizadas, que até a contento, que seriam por si só capazes de levar a condenação, mas tínhamos a vontade realmente de através de quaisquer que fossem os meios obter confissões e pra que pudesse satisfazer nosso ego, mesmo que viessem a qualquer custo, né, inclusive por meio de tortura. E um dos fatos que aconteceram na minha carreira denigre não só a carreira de delegado de policia, mas acima de tudo o ser humano que eu sempre tive a oportunidade de ser através dos ensinamentos dos meus familiares... Em determinada situação, onde um crime bárbaro chocou uma determinada localidade onde eu vivia, um estudante universitário foi barbaramente assassinado por motivo de vingança, onde um determinado elemento tramou toda sua morte e de forma bárbara o executou no auge dos seus 23 anos. Percorrido cerca de 2 a 3 anos de investigações, quando a sociedade clamava realmente por justiça, os pais da vítima realizavam passeatas, faziam conselhos, encaminhavam aos governantes do nosso Estado, várias eram as cobranças, né, então nós sentimos a obrigação de concluir esse inquérito com o máximo de provas. E assim sucedeu-se durante 3 anos, trabalho belíssimo, que foi estragado ao final, quando tive a oportunidade de ter, trabalhando comigo, pessoas especializadas num departamento, especializado da nossa polícia, né, pessoas acostumadas a trabalhar sob o regime de tortura, essas pessoas puderam me dar apoio e ir ao meu lado. Já com o inquérito concluído e com todas as provas capazes de levar ao indiciamento do suspeito, nós, nessa ação realmente tenebrosa da minha vida, o pegamos na calada da noite, quando ela saía do trabalho, jogamos num saco de especiarias, facilmente vendido nos mercados públicos, colocamos dentro de uma mala de um veículo 


\section{Dimensiones histórico-sociológicas de la tortura en comisarías de Brasil: el caso Pernambuco}

e o levamos para outro Estado, dentro de um canavial e lá o submetemos a todos os tipos de tortura possíveis, desde a tortura física, veemente, psicológica, né, com disparo de arma de fogo próximo ao ouvido da vítima, sacos, a utilização de sacos para proibir de respirar, além de vários socos e pontapés e sempre a vítima resistindo a tudo isso, a toda essa série de tortura e caso realmente de se envergonhar qualquer ser humano e muito mais um profissional que se quer dar por respeito. Após toda essa série de tortura o suspeito, mesmo sendo o autor, conseguiu, heroicamente, sofrer todo esse tipo de agressão sem fraquejar. Realmente, aguentou a tudo e todos, todas a agressões sofridas sem confessar, que seria o intento maior, esse fato dele não confessar inclusive levou a uma suspeita que já não mais havia, face aos inúmeros elementos de prova obtidos durante todo o inquérito. Então chegamos realmente a desconfiar que todo o trabalho tinha ido por agua abaixo, por, pelas torturas que foram praticadas não ter surtido efeito. E aí, retornamos, com ele, e jogamos na rua como se joga um saco de lixo, e deixamos ele na rua, se morresse, morresse, porque naquele momento a cegueira do ato insano levou a não ter respeito sequer pela vida humana. Jogamos no meio da rua a toda sorte e ele conseguiu escapar”. (...)

cdlxxvii - “Todos os tipos de atos foram praticados contra ele, né, quanto a violência sexual, houve a penetração de instrumentos no ânus dele, depois, já o instrumento sujo, com fezes, foi colocado na boca dele, né, realmente foram atos praticados, e, fora o sangue que jorrava e foi cuspido, fazia engolir inclusive na areia do chão misturada, fazia com que ele engolisse novamente o próprio sangue misturado com areia, é duro até de descrever." (C14 - entrevista Marzo/2012).

cdlxxviii - "Houve um caso que fez eu repensar essa coisa... Houve uns roubos contra pessoas muito influentes e começamos a investigar. Monitoramos 8 alvos, por vários dias. Então aconteceu o que chamamos de falha mesmo. O pessoal foi monitorado, com escuta telefônica e se descobriu a casa do chefe e que era uma pessoa violenta, tinha armas... Então eu chamei uma equipe que eu sabia da forma como trabalhava, se precisasse de violência eles usavam mesmo, e eu disse: olha, esse é o alvo principal, ele tem armas, é violento, então traga o resultado pra gente. Eu tô dando o alvo e quero

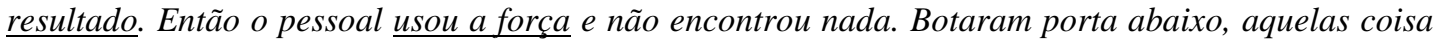
toda e não encontraram nada. Então trouxeram o alvo pro ponto zero, para a delegacia, eu coloquei a escuta telefônica pra ele ouvir, e aconteceu uma coisa que eu nunca tinha visto, quando a violencia é empregada para chegar a algum fim. Porque geralmente um bandido que está sendo molestado, ele tende a entender, muitas vezes, como se aquilo fosse necessário. Ele é o bandido e a policia trabalha daquele jeito então ele merece levar aquelas tapas, ele merece levar aqueles murros, pra ele, faz parte do serviço de policia e é o risco que ele corre. A casa caiu e agora ele vai pagar. Só que o que aconteceu naquele dia eu fiquei impressionado: porque quando o alvo chegou eu disse você é fulano de tal e eu tenho sua conversa gravada... seu nome é fulando de tal... Eu botei a escuta e ele disse meu nome é esse, mas essa voz não é minha - . Seu nome é esse? Como essa voz não é sua?Eu tenho testemunha, escuta... Como não é você? Você está mentindo descaradamente. Pode 'trabalhar' o alvo. E ele foi trabalhado. E toda vez que ele apanhava ele olhava pro meus olhos e dizia: -eu perdoo você, pelo que você está fazendo, mas eu sou inocente - . E toda vez que ele olhava pra mime dizia isso eu comentei, rapaz, eu nunca vi nenhum bandido na vida fazer isso. Eles ficam calados, tem uns que são sangue frio, nem olham pra você, nem diz nada... Mas toda vez que ele apanhava, ele olhava pra todos e dizia: - eu perdoo todos vocês mas sou inocente -. Até que eu parei e disse pra minha equipe vamo parar. Tem alguma coisa errada, isso não e normal. E aí eu disse: chame o resto da gangue e vamos confirmar com eles. Quando a gangue chegou e disse que nunca tinha visto esse cara... Então o policial que trabalhou nesse dia (Al) chegou para mim e disse: faz 4 dias que não consigo dormir, por que toda vez que vou dormir eu vejo aquele senhor, dizendo que me perdoa. $E$ aí? Eu cheguei à conclusão que não quero mais isso pra mim. To perdendo minha paz... Não só não 


\section{Dimensiones histórico-sociológicas de la tortura en comisarías de Brasil: el caso Pernambuco}

quero mais isso, como não tenho mais interesse de ser policial... Isso tirou a minha paz... Eu já vi muito isso e eu descobri que isso tira a sua paz. Que no final, por mais que você chegue ao fim específico, por mais que você se sinta satisfeito por que chegou ao resultado, mas você vê que os meios que usou vão tirando sua paz, por isso não vale a pena... Entao essa foi uma ocorrência que mudou a minha visão que eu tinha sobre a tortura. Fomos injustos, embora com essa operação ganhamos elogios do chefe de polícia, do governador, por que era um pessoal muito influente que estava sendo roubado... Eu já presenciei muita, muita violência, mas nunca tinha presenciado essa reação da vítima... E nem tinha sido nada muito exagerado, houve muito tapa, murro, empurrão, mas nada de exagero". (A2).

cdlxxix - "Veja bem... Hoje eu sou contra todo e qualquer tipo de tortura. Mas recentemente aconteceu um crime de grande complexidade, envolvendo, em um lugar ermo, um homicídio e um estupro, e a única vitima era a pessoa estuprada. E a única coisa que ela lembrava era de pequenas características do acusado, algumas tatuagens. E saímos em busca do acusado até que o encontramos. Como resolver isso? E como agir diante de tanta certeza que era ele? Ele evidentemente não ia confessar. E houve tortura e ele confessou, dando detalhes. Tanto é que a tortura se deu no local do fato. E ele confessou sob ação de tortura. E eu tenho certeza que se assim não fosse feito ele não falaria. (...). o que eu entendo... a tortura é um crime e como todo crime, tem seus excludentes (...) eu acredito nos casos que... é complicado porque tudo depende do caso concreto... Existe situações em que precisa da materialidade do crime e no caso do... Mas voltando à resposta eu sou contra e declaradamente contra a toda forma de tortura. Não existe mais tortura diante de mim... é complicado... enfim, particularmente, eu acredito que nos casos que eu acreditasse que precisava muito acreditar que se tinha aquela informação e eu poderia obter aquela informação eu torturaria sem problema algum." (A1).

cdlxxx - "Então chegou o momento em que uma pessoa foi presa, certo, envolvida, certo, também num assalto a banco, certo, então o informante disse que eles estão na frente da casa, estão bebendo, certo, em frente, estão no morro da conceição, no alto do morro, certo, estão com armas, certo, então nós fomos para o local certo, tinha três pessoas, certo, três maloqueiros lá bebendo, certo, e eles foram presos, certo, agente trouxe todo mundo e botou no carro, certo, e saiu, foi para o açude de Apipucos perto de uma casa abandonada, e lá, colocamos, o delegado seccional estava presente, $e$ essas pessoas estavam algemadas, todas, né, com saco na cabeça para não identificar ninguém. E começamos pelo mais novo, certo, o pessoal dizia que ele era um dos mais ativos nos assaltos, né. E ele foi colocado, né, pendurado, amarrado pelas pernas, certo, e foi colocado um ponto de apoio pra ele perto do açude e ele era colocado dentro do açude, certo, e retirava para ele dizer onde estavam as armas, certo. Ele, lá pras tantas, depois de beber tanta água, estava de cabeça para baixo, ele deu duas pistolas que estavam dentro do carro, na parte da porta (... - detalhes de onde estava a arma). Mas o que interessava não era aquelas pistolas, o que interessava era a metralhadora, o fuzil, certo, $e$ o dinheiro roubado, certo, E nesse caso aí, certo, depois a gente percebeu, que ele tava com outra pessoa que era o irmão, que foi também feito a mesma coisa, certo, na presença dele, certo, e nenhum dos dois deu mais do que isso. Né. Então eles desmaiaram, duas vezes, né, sangraram muito pelo nariz e pelos ouvidos, mas a gente chegou um momento de concluir que ele não era a pessoa do assalto, né. Eles realmente tinham feito alguns assaltos, né, recuperou-se pistolas e tal, mas eles não tinham participado daquele assalto. Então eles passaram ainda um dia no xadrez, certo, da delegacia, então foi preferível coloca-los em liberdade sem fazer nenhum procedimento porque eles estavam muito machucados, muito machucados mesmo. E como eles não tinham ciência, certo, de quem estavam torturando eles, certo. Então foram deixados em aldeia, num vilarejozinho próximo, $e$ não tivemos mais contatos com eles. Isso è um aspecto negativo. $O$ informante, o cara que deu isso, 


\section{Dimensiones histórico-sociológicas de la tortura en comisarías de Brasil: el caso Pernambuco}

também sofreu, por ter dado a parada errada. E esse foi um dos casos que não teve êxito. Não teve o que nós queríamos... E dando sequencia a essa investigação desse banco...” (C15).

cdlxxxi - "Então fomos ao local e predemos quatro. Então fomos para uma fazenda nos arredores de Recife, onde um político conhecido da gente tinha vários bichos em casa, certo, e ele tem uma cobra, ele diz que é rainha o tipo de cobra. Uma cobra venenosa que ela fica em um quadrado de madeira e tem uma parte lá na frente que é de vidro, um vidro grosso, (...) e lá, numa das dependências da fazenda, todos os policias encapuzados e ele foi colocado sentado na cadeira, amarrado, certo, e o pé ia ser colocado dentro da caixa. Agente deu duas tapas com uma paletazinha na cobra ela toma posição de ataque, inclusive muito bonito mesmo, porque ela se enrroscava, se preparava e as duas presas ficavam salivando de raiva, e foi colocado o pé, e ele tava com pedra de dominó dentro da boca, várias pedras de dominó dentro da boca. Nem podia falar, nem impedia a respiração. Se botar pano chega um momento que ela cansa e a respiração com pano molhado tampa a respiração, deixa ele sem ar e pode até morrer sem dar a informação. (...detalhes da eficiência do dominó) mas o desespero e o pânico dos outros, certo, então, quando viu a cobra não acreditou e ele foi mordido pela cobra. E foi observado que cinco a dez minutos ela dizia não tá enxergando mais, certo. Não enxergava e percebeu-se que ele tava com febre alta. E o segundo, vendo tudo isso, não resistiu, viu que não era brincadeira, e disse que as armas tinham participado do assalto e que todas as armas estavam guardadas perto do (...detalhes de onde estavam as armas e como foram recuperadas). E foi tudo recuperado, inclusive de vários outros assaltos, foi uma apreensão boa, foi passado para as autoridades. Eles foram autuados em flagrante. O que foi mordido pela cobra foi hospitalizado, não chegou a morrer, estourou o corpo todinho, ele foi hospitalizado. Foi dito que ele fugou na mata, a mata realmente é grande, é perigosa. Foi dito que ele fugou e ele hospitalizado, mas ele morreu recebendo atendimento. Ele morreu. Os outros, teve a irmã e a mãe de dois deles que estavam no local, foram presas também, mas em negociação, certo, eles preferiram para não indiciar a mãe e nem a irmã do outro preferiram que soltassem elas que eles não falariam nada sobre a tortura, foi negociado, c, foi dito que eles foram presos com as armas mas não tinha também imagens deles pois eles estavam encapuzados, e então vai dizer que vocês estavam com as armas, mas o advogado de vocês vai defender dizendo que não eram vocês. Então eles aceitaram, foram presos e autuados pelo porte das armas e um morreu no hospital e eles já estão todos soltos, roubando de novo, porque já apareceram algumas imagens" (...detalhes).

cdlxxxii - "O dono da cobra é um político, (...) e ele é sádico. Ele participa, ele presencia, e acha maravilhoso, vibra, certo, conseguiu agora, recentemente uma outra cobra, tem uma coral pequena, ele teve a informação que tem duas cobras corais: a verdadeira, e tem a falsa, que não tem veneno, certo. Então, interessante que para saber se era verdadeira, certo. ela realmente mordeu, passou mal, não chegou a morrer, certo, foi atendida no local por um médico que foi chamado e aplicou uma injeção que não sei qual é, o doente tava encapuzado, com um saco na cabeça, então não viu quem era. E realmente ele não morreu. E como ele tinha um filho envolvido, certo, então nenhum dos dois foi preso. Então ele não contou nada da tortura porque se ele contasse da tortura ele teria que dizer que ele tinha um homicídio, ele mata o cara que botava gaia no filho dele, então em troca do silencio ele também foi liberado e não falou absolutamente nada. E o político (...) mantém essa cobra, ele tem cobras maiores, ele tem um tanque com, não sei se é crocodilo ou jacaré que não cresce muito... Tem um outro caso interessante (...) e o empresário tava pedindo para investigar, ele tinha matado o filho dele um menino com 16 anos, ele atirou na cabeça (...) Então nós começamos a trabalhar nessa investigação até que ele foi identificado, nós levamos ele para uma valeta no (...) e ele foi levado pra lá e o empresário foi levado pra lá pra ver, ele queria ver o camarada. Então ele foi levado para o local, certo, e ele mesmo arrancou todos os unhas com alicate, da mão e dos pés, certo. Ele queria 


\section{Dimensiones histórico-sociológicas de la tortura en comisarías de Brasil: el caso Pernambuco}

ver, ele disse você vai sofrer primeiro, mostrou o retrato do filho dele ao bandido, ao homicida e assaltante, tirou todas as unhas dele, e interessante é que não satisfeito ele levou um maçarico e acendeu, e ele queria filmar a ação, e agente disse a ele olha não é interessante filmar, mais cedo ou mais tarde isso cai nas mãos de alguém, tá entendendo? E ele ligou o maçarico e torrou todos os dentes, era interessante, o cara desmaiava e acordava, aí ele jogava elixir sanativo no local, aí o cara melhorava, e ele torrou todos os dentes, certo, ele queimou todas as mãos, o pênis, né, (...) o cara tava transtornado. E depois queimou ele todinho no maçarico. Ele todinho. Ele é um grande empresário na área de (...), tem várias empresas, importa, um cara muito poderoso. Mas, interessante é que nós achávamos que isso fosse dar uma tranquilidade, ele vivia muito perturbado que queria vingar o filho, e após vingar o filho ele ficou mais perturbado do que era".

cdlxxxiii - "Tá provado pelos outros que participaram, que muitas vezes eu alerto, ó deixa com agente, deixa isso com a polícia, "não, mas eu quero participar" e quando participa a pessoa não e mais a mesma. Não é mais a mesma. Até mesmo bandido que torturaram e que hoje a gente vê que ele não teve estrutura de suportar o que fez". (...).

cdlxxiv - "Vários policiais também não tem estrutura. Tem policial hoje que tá no Recursos humanos, tem policial hoje que desenvolveu uma espécie de tumor, as vezes na garganta, tumor na cabeça, cara que passou a ter doenças que a gente vê que é mais por conta do remorso, por conta de um arrependimento, que se transforma inclusive, um, ficou constatado mesmo que o medico disse você não tem nada, você tá criando essa doença. Tem que ter estrutura”.

cdlxxv - "Tem um que recentemente ele pediu aposentadoria. Interessante que ele tá vendo o vulto, ele tá internado, fazendo tratamento psicológico, porque ele tá vendo as pessoas que ele torturou. Embora agente tenha dito a ele, no inicio, meu velho é o seguinte, você não fez por fazer, por maldade, por instinto. Você fez procurando uma informação de uma coisa que você já sabia. Ninguém tá fazendo adivinhação. Ninguém pegou um camarada, olha esse camarada é um suspeito, é um cara assim, agente não sabe se ele participou ou não, então vamos tirar a dúvida. Não. Era pessoas que era dado ou por parente, ou por informantes, ou inimigos da própria gangue. Que isso acontece muito, o cara se desentender dentro do grupo e ser humilhado por um líder ou por alguém da quadrilha. E ele vai, dá pra mão, não sai do grupo, muitas vezes ele vem preso também, passa por alguma sessão de tortura, é afastado, pronto, só pra justificar a prisão dele e ele dá por algum motivo. Receber menos que os outros, ser humilhado dentro do grupo. Tinha um que se apaixonou por uma das mulheres da quadrilha e ela também se apaixonou por ele, só que e o líder, era um homicida (...), e interessante que ele humilhava o colega. Ele sabia que estavam namorando, que estavam apaixonados, mas o cara só pra desmoralizar ele, dizia: ó tua mulher vai dormir comigo hoje (...) Então o Diego tomado pelo ciúme ele veio e confessou. Ele confessou abertamente que participou de vários assaltos, ele participou de uma quadrilha (...) E essas pessoas agente conseguiu prender e eles passaram pela mesma sessão (...) E ele foi levado para o açude e dentro do açude tinha uma placa de cimento que seria no passado alguma ponte alguma coisa que fizeram no açude $e$ ficou aquela placa no lugar. Então ele foi colocado na placa e ficou todo mundo esperando a maré subir. E a agua subindo, subindo, e agente ia sair e ai disse, agora é você e a sorte, a maré vai subir, você não vai suportar, se não falar agente vai na sua casa e trazer alguém de sua família e vai passar o mesmo que você. Aí ele realmente entregou (... detalhes dos roubados e como foram encontrados). Ele foi preso e interessante que hoje ele é uma pessoa completamente transformado. E eu converso com ele no presídio, ele tá pra ganhar a liberdade, ele é uma pessoa evangélica (...) mas ele abriu mão de tudo dentro da cadeia. É incrível! a conduta dele e ele chamou o irmão mais novo que tava no crime, reuniu, conversou, e ele conseguiu transformar o irmão que tava no crime (... ). Esse é o único 


\section{Dimensiones histórico-sociológicas de la tortura en comisarías de Brasil: el caso Pernambuco}

caso, agente não conhece outro caso. (...) Mas ele mostrou nos últimos três anos um comportamento completamente diferente, mas o comportamento dele é interessante. oje ele faz um trabalho muito interessante.... a gente vê dele tanta sinceridade”.

cdlxxxvi - “É, pois é, pra ele contar, ele teria que entregar a filha, entregar a esposa, porque elas estiveram no local, elas presenciaram muitas cenas. Então eu acredito que mesmo num acesso de loucura ele se bloquearia pra contar. Ele pra contar ele teria que estragar a vida dele, empresário bem sucedido, um cara muito orgulho, muito prepotente. Ele tinha aquela sede de vingança, agora depois da vingança o cara se desequilibrou, ele tava arrependido, mas não podia fazer mais nada. Ele não podia contar, certo. Ele hoje o filho assumiu a empresas, certo, e ele hoje tá feito um mal de Alzheimer quase que colocado, quase que espontâneo, porque ele faz questão de não lembrar de nada, de não reconhecer as pessoas (...), isolou-se do mundo..."

cdlxxxii - "Uma saúde de bicho, porque o Cabeça tinha apanhado, tinha levado saco, Cabeça tomou óleo queimado, foi enterrado vivo. E que saúde, meia hora desenterrado e parecia que Cabeça não tinha nada. Que saúde de bicho”.

cdlxxxviii - "Houve situações de destaque. A casa de um deles, uma pessoa do governo, foi invadida e foi levado um notebook que tinha informações muito importantes que estavam no pen drive e estava na máquina. E a pessoa que entrou na casa rendeu, levou dinheiro, muitos dólares, levou arma e levou isso aí. Então o cara ficou desesperado. Então um dos assessores disse olha ele paga bem”.

cdlxxxix - "Trabalhava numa delegacia que não tinha nada ver. Agente, aliás, agente era 50\% atuava na área, mantinha tal, porque essa paixão pela polícia, não tinha hora, não tinha dia da semana, vamos fazer blitz, disque denuncia, entrar na casa de suspeito, entrar na casa de bandido e, via de regra dava certo, porque agente só dava botada nos locais minados, pontos vermelhos... E, 50\% é pedido. (...) Não. Não tinha nada a ver com a nossa área. O pessoal falou bota o delegado no circuito para ver se ele recupera”.

cdxc - "Exatamente. Esse assessor ele com uma pessoa da corregedoria. E ele disse: olha eu não vou me meter, mas pode usar o meu nome que ele vai atender (...). E o interessante que nesse roubo foi levado uma bola de futebol americano, autografada por vários jogadores americanos, era uma relíquia e foi levada por essa pessoa que nem sabia o que tava levando. Então começamos a investigação. Só que pelo local de acesso, só tinha acesso alguém que conhecesse a casa. A primeira coisa era alguém que conhecesse a casa. Mas a segurança não mostrou nada, as câmeras essa, era na casa do representante do governo não mostraram nada. Então a conclusão era que tinha sido alguém de casa. Então por eliminação, restou para um rapaz que era uma espécie de caseiro, mas era da confiança da família, então perguntamos de quem podemos desconfiar? Olha, de ninguém. Ó e esse rapaz? Esse rapaz chegou com seis anos de idade e estava com dezenove. Então era o camarada que se quisesse fazer alguma coisa ele fazia abertamente, podia dar um pipoco, porque ele tinha senha, o política não tinha controle de todas as contas, ele pegava o cartão do político, sabia a senha, ele pegava o saldo, então era um camarada de confiança. Agente disse tem que começar por ele. Então tudo bem, quando ele saíu para ir para casa, seguramos ele. Aí levamos, certo, ele pra Jaboatão, pra uma casa de um vigilante que era amigo nosso, morava só, e lá ele ficou sentado, amarrado na cadeira, levou um banho, um banho bem bom de agua, nu. E o cara puxou duas pernas de fio aí agente dava cada choque que o cara tremia do cabelo a unha do pé e se batia, algemado. Aí quando ele se recuperou-se aí agente disse pega a irmã dele, que ela vive com ele e se ele levou pra casa ela sabe. Quando ele viu que ia pra irmã, aí ele disse que ia colaborar, mas não deu coisa com 


\section{Dimensiones histórico-sociológicas de la tortura en comisarías de Brasil: el caso Pernambuco}

coisa. Mas aí agente pegou ele e foi pra casa da irmã com quem ele morava. E buscou-se tudo, baculejou tudo. A irmã levou muita tapa na cara, muita tapa na cara mesmo. Ficou na cadeira nua sentada, ela constrangida, aí na hora de levar, nós encontramos drogas, nós encontramos roubo de energia, vai ser autuado em flagrante, encontramos maconha no quarto dele, pronto vai ser autuado todo mundo. Ela também pela quantidade. E na hora de ir embora o policial com uma lanterna, ilumina embaixo da cama, aí diz não aqui não tem nada não, só tem uma bola velha, inclusive oval que nem presta pra jogar. Agente saindo aí parou: bola velha, oval, tire essa bola! Quando ele puxou a bola, olha foi uma alegria, todo mundo deu grito de alegria porque era a bola americana, autografada. Aí ele deu o jogo (... detalhes do roubo e materiais recuperados). Agente recuperou, só que do homem do governo agente não recebeu absolutamente nada, nem uma aperto de mão, nem um obrigado (...)".

cdxci - "Patrimoniais. Patrimoniais. E roubo na casa, e o cara que leva o carro e o notebook, principalmente o notebook, leva celulares de ultima geração. Mais recentemente teve uns políticos que se desentenderam por conta de um roubo (...)”.

cdxcii - "Noventa por cento dos pedidos vem de pessoas da alta cúpula, certo. Vem juiz, Ministério Público, políticos. Que vem, quando ele não vem diretamente, mas conhece alguém, um assessor, tal, esse é o pedido de fulano e agente vai e atende. E 99,9\% tem dado êxito. Tem resultado, porque quando se pega uma pessoa para se fazer adivinhação, o que nos deixa mais tranquilo com relação a esses métodos é porque agente não faz, como muitos fazem, tá entendo, que é a adivinhação, olha é um cara da área, aquele cara é ladrão então aquele cara deve conhecer alguém que toma conhecimento do assunto e possa dar uma informação para pegar o camarada. Então vamos usar o método, o cara vai pro pau, o cara vai pro saco, vai pro banho, o cara vai beber óleo. Interessante que é a pedra de enxofre que o médico nos disse. Você pega uma pedrinha de enxofre, você bota ela dentro d'água ela vai filtrando a água. Ela vai filtrando a agua e ela é efervescente. Uma pedrinha de enxofre dentro do organismo, por menor que ela seja, ela vai efervescendo e ela vai para dentro do fígado. Aquele pozinho se infiltra dentro do fígado. Ele diz que vai comendo o fígado por dentro, tá entendendo. Então, trinta dias no máximo, no máximo, o cara pensa que é cirrose, pensa que é câncer, pensa que é outra doença, não dá o diagnóstico. O enxofre não é diagnosticado dentro. Mas ele vai comendo por dentro e o cara vai a óbito sem dúvida nenhuma, tá entendo. Então ... se der algo errado, dá a pedrinha de enxofre e aguarda, que é dois meses, mesmo que ele denuncie, é em fase de inquérito policial, mas ele não chega a sentença, porque na hora dele ser ouvido em juízo ele tem morrido em algum lugar e a falta de provas, só baseada em inquérito policial, com um bom advogado, né, como muitos tem dito, a pessoa não fica provado nada. E ainda causa distúrbios, delírios, parte vai para o cérebro e a pessoa mesmo que denuncie, mas a partir daquele momento, um dia depois ele começa com ideias e frases desconecta, o enxofre causa isso. Então foi dito por um médico, um médico de um grande hospital, é um pesquisador preparado, ele precisou e ele disse usa isso aí no camarada que ele vai falar alguma coisa quando você perguntar é quase como uma hipnose o cara vai dizer, ele tem lapsos na memória que ele diz coisas sem raciocinar, sem nada, tá entendendo? (... detalhes minuciosos da recuperação dos bens) Entramos na casa, deu um baculejo, o filho da mulher já tinha sido preso, mostramos as fotos do GPS e dissemos, olha o celular tá aqui. o menino disse olha tem bastante tempo que agente não tem feito isso... Então é a senhora, é a mãe, então a mãe vai pro saco e então quando foi colocado o saco na mãe, com os filhos".

cdxciii - "Oh, meu velho, não tem fim não”. 